\title{
Heterologous expression of cellulase genes in natural Saccharomyces cerevisiae strains
}

\author{
Steffi Angela Davison
}

Thesis presented in fulfilment of the requirements for the degree of Masters of Science in the Faculty of Microbiology at Stellenbosch University

Supervisor: Prof. Willem Heber (Emile) van Zyl Co-supervisor: Dr. Riaan den Haan 


\section{Declaration}

By submitting this thesis/dissertation electronically, I declare that the entirety of the work contained therein is my own, original work, that I am the sole author thereof (save to the extent explicitly otherwise stated), that reproduction and publication thereof by Stellenbosch University will not infringe any third party rights and that I have not previously in its entirety or in part submitted it for obtaining any qualification.

Date: March 2016

Signature: Steffi Angela Davison

Copyright @ 2016 Stellenbosch University

All rights reserved 


\section{Summary}

The yeast Saccharomyces cerevisiae is regularly chosen for the heterologous production of industrial and medically relevant proteins, due to its rapid growth rate, high cell density fermentation capabilities, microbial safety and eukaryotic post-translational processing. Identifying strains with superior secretion and production of recombinant proteins, whether for pharmaceutical, agricultural or industrial processes, has the benefit of lowering production costs. This holds true for second generation $(2 \mathrm{G})$ cellulosic bioethanol production, where high titers of key cellulolytic enzymes are needed to break down complex lignocellulosic substrates. While several secretion-enhancing strategies have been attempted in heterologous production hosts, these strategies were limited by bottlenecks in the secretory pathway. Although protein characteristics and host restrictions are likely to contribute to these bottlenecks, these limitations are poorly understood.

Exploiting naturally occurring yeast variants has shown great potential to identifying strains with varying fermentation profiles and tolerance to industrial stresses. The same variation is expected in the secreted and total heterologous cellulolytic activity levels between natural S. cerevisiae strains. Many natural yeast strains may not be suitable for direct industrial fermentation, however industrially relevant traits could be transferred to industrial strains, thereby creating a novel yeast strains with extra beneficial features. In this study, the potential of natural S. cerevisiae strains with regards to superior cellulolytic activity levels, robustness and other ideal characteristics for $2 \mathrm{G}$ cellulosic bioethanol production were evaluated.

Preliminary screening of thirty natural strains for the production of Saccharomycopsis fibuligera Cel3A (S.f.Cel3A) activity demonstrated variation in secreted cellulase activity levels, allowing us to select seven strains with promising phenotypes. After cellulase genes were expressed on episomal and delta integrative plasmids in $S$.cerevisiae strains, the secreted activity yields of episomally produced Trichoderma reesei Cel5A (T.r.Cel5A) and Talaromyces emersonii Cel7A (T.e.Cel7A) were 3.5- and 3.7-fold higher in natural strain YI13 compared to reference strain S288c. However, no single strain had highest secreted activity for all three enzymes, suggesting cell specific activity levels is dependent on the genetic background of the host and properties of the protein. Nevertheless, YI13 was identified to be highly tolerant to secretion and cell wall stresses (predicted to result in higher cell specific activities). 
After evaluating other industrially relevant characteristics including growth vigour, fermentation vigour and tolerance to industrial stressors, natural strains were identified to have promising features for $2 \mathrm{G}$ cellulosic ethanol production. Variation in the fermentative (YP-glucose and Avicel cellulose) profiles of S. cerevisiae strains are observed, with the natural strains producing similar titers of ethanol $(9.0 \mathrm{~g} / \mathrm{L})$ compared with the benchmark MH1000 strain in YP-glucose fermentation conditions. Multi-tolerance traits to industrial stresses were demonstrated by the YI13 strain including high ethanol tolerance $(10 \% \mathrm{w} / \mathrm{v})$, high temperature tolerance $\left(37^{\circ} \mathrm{C}\right.$ and $\left.40^{\circ} \mathrm{C}\right)$, and tolerance to a cocktail of inhibitory compounds found in lignocellulosic hydrolysates, suggesting that this strain has a balance between an effective secretion pathway and robustness to withstand environmental conditions. These strains are a significant step toward creating an efficient cellulase secreting yeast for $2 \mathrm{G}$ bioethanol production. 


\section{Opsomming}

Die gis Saccharomyces cerevisiae word dikwels vir die heteroloë produksie van industriële en medies-toepaslike proteïene gebruik, weens sy vinnige groeitempo, hoë seldigtheid, fermentatiewe vermoëns, mikrobiese veiligheid en eukariotiese na-transleringsprosessering. Die identifisering van stamme met buitengewoon goeie sekresie en produksie van rekombinante proteïene, hetsy vir farmaseutiese, landbou of industriële prosesse, kan baie voordelig wees vir die vermindering van produksiekoste. Dit geld ook vir die produksie van tweede generasie (2G) sellulolitiese bio-etanol, waar 'n groot hoeveelheid sellulolitiese ensieme benodig word om komplekse sellulosesubstrate af te breek. Alhoewel daar reeds verskeie strategieë gebruik is om die sekresievermoë van heteroloë produseerders te verbeter, was hierdie strategieë beperk deur bottelnekke wat in die sekresie pad van die gasheerselle voorgekom het. Die beperkings van hierdie gasheerselle en die proteïeneienskappe wat bydra tot die knelpunte, word swak verstaan.

Studies van gisvariante wat natuurlik voorkom het getoon dat daar groot potensiaal in die identifisering van stamme met wisselende fermentasie profiele en verdraagsaamheid vir industriële drukke lê. Dieselfde variasie word in die uitgeskeide en totale heteroloë sellulolitiese aktiwiteitsvlakke tussen natuurlike $S$. cerevisiae stamme verwag. Baie natuurlike gisstamme is geskik vir direkte industriële fermentasie, maar in die industrie kan betrokke eienskappe ook aan industriële stamme oorgedra word, om sodoende ' $\mathrm{n}$ gisras te skep met ekstra voordelige funksies. In hierdie studie is die potensiaal van natuurlike $S$. cerevisiae stamme met betrekking tot beter sellulolitiese aktiwiteitsvlakke, robuustheid en ander ideale eienskappe van die $2 \mathrm{G}$ sellulosiese bio-etanol produksie geëvalueer.

Voorlopige ondersoeke van dertig natuurlike stamme se produksie van Saccharomycopsis fibuligera Cel3A aktiwiteit het gedemonstreer dat daar ' $n$ variasie is in die afskeiding van sellulase-aktiwiteitsvlakke, wat ons toegelaat het om sewe van die stamme met belowende fenotipes te identifiseer. Nadat drie sellulasegene op episomale en delta geïntegreerde plasmiede in S. cerevisiae stamme uitgedruk was, was die uitgeskeide opbrengste van episomaal-geproduseerde Trichoderma reesei Cel5A en Talaromyces emersonii Cel7A aktiwiteite van die natuurlike ras YI13 onderskeidelik 3.5 - en 3.7 - keer hoër in aktiwiteit as die verwysingsras S288c. Wanneer die hoogste uitskeidingsaktiwiteit van die drie gene in verskillende stamme egter vergelyk word, het nie een van die stamme uitgestaan vir die hoogste sekresieproduksie van al die ensieme nie. Dit dui daarop dat selspesifieke aktiwiteits vlakke 
afhanklik van die genetiese agtergrond van die gasheersel en die eienskappe van die proteïne was. Nietemin, is YI13 as hoogs verdraagsaam vir sekresie en selwandspanning geidentifiseer. $\mathrm{Na}$ die evaluering van ander industrieel-relevante eienskappe, insluitend groeikrag, fermentasiekrag, en verdraagsaamheid van industriële stressors is daar getoon dat verskeie natuurlike stamme belowende eienskappe het vir die produksie van $2 \mathrm{G}$ sellulolitiese etanol. Variasies is in die fermentatiewe (YP-glukose en Avicel sellulose) profiele van S. cerevisiae stamme waargeneem, waar die natuurlike stamme soortgelyke hoeveelhede etanol $(9.0 \mathrm{~g} / \mathrm{L})$ vervaardiging het, wat ooreenstem met die fermentasiekondisies van die verwysingsras MH1000 in YP-glukose. Multi-verdraagsaamheid eienskappe in industriële stamme is vir YI13 geïdentifiseer, waaronder hoë etanol verdraagsaamheid $(10 \% \mathrm{w} / \mathrm{v})$, temperatuur $\left(37^{\circ} \mathrm{C}\right.$ en $\left.40^{\circ} \mathrm{C}\right)$, en die verdraagsaamheid van 'n mengsel van inhiberende verbindings gevind in sellulose hidrosilate ingesluit was. Dit dui daarop dat hierdie stam 'n balans het tussen 'n effektiewe afskeidingspad en duursaamheid om omgewingstoestande te weerstaan. Hierdie stamme verteenwoordig ' $n$ belangrike stap in die skep van 'n doeltreffende gis wat sellulases afskei vir produksie van $2 \mathrm{G}$ bio-etanol. 


\section{Acknowledgments}

I wish to express my sincere gratitude and appreciation to the following persons and institutions for their invaluable contributions to the successful completion of this study:

- My parents, Susan and John Davison, to whom this thesis is dedicated. Thank you for supporting me (financially and emotionally) through all my years at university; for believing in me and allowing me to follow my dreams.

- My brother and sister, Jason and Megan, for their constant encouragement and understanding.

- Prof. W.H. van Zyl, Department of Microbiology, University of Stellenbosch, who acted as my supervisor, for accepting me as a student, for his constant enthusiasm, encouragement and allowing me to grow as a biologist.

- Dr. R. den Haan, Department of Microbiology, University of the Western Cape, who acted as my co-supervisor, for his academic guidance, patience, proof-reading, dry sense of humour and heart-warming stories.

- My co-workers in Lab 335 who help and guided me over the years: Heinrich (smartest guy I know), Lisa (for proving that women can look good doing science), John-Henry (we'll always have Italy), Maria (for all the hugs), Bianca (baby bones), Marlin, Trudy and Annatjie.

- The Staff of the Microbiology Department.

- My friends, especially Annica (for second chances), Nicole (who made everything up), Veronique (for being just a little bit), Kalyn (for wine and Pulse nights), Linda (for being my person) and Monica (for lunch and moaning sessions), but overall for their understanding and encouragement, and above all their friendship.

- National Research Foundation and University of Stellenbosch for financial support. 
"Look deep into nature and then you will understand everything better." Albert Einstein (1897-1955) 


\section{Index}

\section{CHAPTER 1: GENERAL INTRODUCTION, PROBLEM STATEMENT AND PROJECT AIMS}

1.1. General introduction: 1

1.2. Problem Statement 2

1.3. Aims and interests of the study 4

1.4. References 6

CHAPTER 2: REVIEW OF LITERATURE 11

2.1. Bioenergy: Biofuels 11

2.2. Biofuels according to technology 12

2.2.1. First generation (1G) biofuels $\quad 12$

2.2.2. Second generation (2G) biofuels 13

2.3. Feedstocks for biofuel types 18

2.3.1. Substrates for $1 \mathrm{G}$ technology 18

2.3.2. Substrates for $2 \mathrm{G}$ technology 19

2.4. Steps in $2 \mathrm{G}$ ethanol production 21

2.4.1. Pre-treatment and inhibitors 21

2.4.2. Cellulose hydrolysis by cellulolytic enzymes 23

2.4.3. Fermentation and process configurations 32

2.4.3.1. Environmental stresses in CBP and general stress response 33

2.4.3.1.1. Variation in tolerance capabilities of S. cerevisiae strains 36

2.5. Hosts for recombinant DNA technology 30

2.5.1 Saccharomyces cerevisiae as CBP hosts 39

2.5.2. Expression of cellulase genes $\quad 41$

2.5.2. Protein secretion capacity and secretion stress 44

2.6. Diversity of Saccharomyces cerevisiae: Industrial and laboratory strains 47

2.6.1 Exploitation of natural diversity for industry 48

2.7. This study $\quad 50$

2.8. References $\quad 50$

CHAPTER 3: HETEROLOGOUS EXPRESSION OF CELLULASE GENES IN NATURAL SÁCCHAROMYCES CEREVISIAE STRAINS

$\begin{array}{ll}\text { Abstract } & 67\end{array}$

3.1. Introduction $\quad 68$

3.2.1. DNA manipulation and yeast transformation $\quad 71$

$\begin{array}{ll}\text { 3.2.2. Strains } & 73\end{array}$

$\begin{array}{ll}\text { 3.2.3. Enzyme activity assays } & 73\end{array}$

$\begin{array}{ll}\text { 3.2.4. Ploidy determination } & 74\end{array}$

$\begin{array}{ll}\text { 3.2.5. Gene copy number } & 75\end{array}$ 
3.2.5. Growth analysis $\quad 75$

3.2.6. SDS-PAGE, zymograms and $N$-deglycosylation $\quad 75$

3.2.7. Oxygen-limited fermentation in $2 \%$ glucose YP media 76

3.2.8. Co-culture fermentations using Avicel cellulose 76

3.2.9. Screening for tolerance to bioethanol-specific stressors 77

3.3. Results and discussion $\quad 79$

3.3.1. Preliminary screening for superior S.f.Cel3A activity from natural transformants 79

3.3.2. Recombinant T.r.cel5A and T.e.cel7A activity of selected natural strains 83

3.3.3. Plasmid and integrated gene copy numbers $\quad 87$

3.3.4. Transformant stability and ploidy determination of natural strains. 89

3.3.5. Growth rates between transformants $\quad 92$

3.3.6. Fermentation and S.f.Cel3A activity in oxygen-limited conditions 94

3.3.7. Co-culture fermentations using Avicel cellulose 98

3.3.8. Phenotyping natural strains for bioethanol specific stresses and secretion stresses 104

3.4. Conclusions $\quad 110$

3.5. References 110

CHAPTER 4: GENERAL DISCUSSION AND CONCLUSIONS 119

4.1. General discussion $\quad 119$

4.1.1. Differential heterologous cellulase activity 120

4.1.2. Tolerance to environmental and metabolic stresses 122

4.2. Conclusions $\quad 124$

4.3. Future prospectives $\quad 125$

$\begin{array}{ll}\text { 4.4. References } & 128\end{array}$

CHAPTER 5: ADDENDUM 120

5.1. Results and supplementary data not included in previous chapters 131

5.1.1. Empty vector constructions 131

5.1.2. Primers for qPCR copy number determination and Mat gene amplification $\quad 132$

5.1.3. Scatter plots from flow cytometry 132

5.1.4. Histogram statistics 133

$\begin{array}{ll}\text { 5.1.3. Ethanol tolerance assays } & 134\end{array}$

5.1.4. Composition of the inhibitory cocktail 135

$\begin{array}{ll}\text { 5.1.5. Cell viability assays } & 137\end{array}$

5.1.6. Protein determination 137

5.1.7. Growth assays of transformants in aerobic conditions 139

5.1.8. Raw data of co-culture fermentations with Avicel cellulose $\quad 140$

5.1.9. Raw data of stress tolerance assays $\quad 140$

5.1.10. Stress tolerance compounds and mode of action 141

$\begin{array}{ll}\text { 5.2. References } & 142\end{array}$ 


\section{List of Abbreviations}

\begin{tabular}{|c|c|c|c|}
\hline $1 \mathbf{G}$ & first generation & GH & glycosyl hydrolase \\
\hline $2 \mathbf{G}$ & second generation & GPI & glycosylphosphatidylinositol \\
\hline ATP & adenosine trinhosnhate & GRAS & generally regarded as safe \\
\hline & & HOG & High Osmolarity Glycerol \\
\hline BGL & $\beta$-glucosidase & HSP & heat shock protein \\
\hline $\mathrm{C}_{\mathrm{t}}$ & cycle threshold & HSR & heat shock response \\
\hline CAZY & carbohydrate active enzyme & HPLC & $\begin{array}{l}\text { High performance liquid } \\
\text { chromatography }\end{array}$ \\
\hline CBH & cellobiohydrolase & IRENA & international renewable energy \\
\hline CBM & cellulose binding domain & & agency \\
\hline CBP & consolidated bioprocessing & LPMO & $\begin{array}{l}\text { lytic polysaccharide } \\
\text { moonoxygenase }\end{array}$ \\
\hline CD & catalytic domain & mRNA & messenger ribonucleic acid \\
\hline CER & common environmental response & MULac & methylumbelliferyl- $\beta$-D-lactoside \\
\hline CFU & colony forming units & N/A & not applicable \\
\hline CMC & carboxymethyl cellulose & OD & optical density \\
\hline $\mathrm{CO}_{2}$ & carbon dioxide & PASC & phosphoric acid swollen cellulose \\
\hline $\mathbf{C R}$ & Congo Red & PCR & polymerase chain reaction \\
\hline DCW & dry cell weight & PI & propidium iodide \\
\hline DIC & differential interference contrast & $p \mathbf{N P}$ & $p$-nitrophenol \\
\hline DMSO & dimethyl sulfoxide & $p$ NPC & $p$-nitrophenyl- $\beta$-D-cellobioside \\
\hline DNA & deoxyribonucleic acid & $p$ NPG & $p$-nitrophenyl- $\beta$-D-glucopyranoside \\
\hline DNS & 3,5-dinitrosalicylic acid & qPCR & quantitative polymerase chain \\
\hline DTT & dithiothreitol & & reaction \\
\hline ESR & environmental stress response & SC & synthetic complete \\
\hline EC & enzyme commission number & SDS-PAGE & $\begin{array}{l}\text { sodium dodecyl sulphate - } \\
\text { polyacrylamide gel electrophoresis }\end{array}$ \\
\hline EDTA & ethylenediaminetetraacetic acid & SHF & separate hydrolysis and \\
\hline EG & endoglucanase & & fermentation \\
\hline EH & enzyme hydrolysis & SSC & side scatter light \\
\hline $\mathbf{E R}$ & endoplasmic reticulum & SSF & $\begin{array}{l}\text { simultaneous saccharification and } \\
\text { fermentation }\end{array}$ \\
\hline ERAD & $\begin{array}{l}\text { endoplasmic reticulum associated } \\
\text { degradation }\end{array}$ & TM & tunicamycin \\
\hline FDA & food \& drug administration & $\mathbf{U}$ & units \\
\hline FSC & forward scatter light & UPR & unfolded protein response \\
\hline gDNA & genomic deoxyribonucleic acid & vs. & versus \\
\hline Gg & gigagram & YPD & yeast extract, peptone, glucose \\
\hline
\end{tabular}




\section{List of Tables}

Table 2.1. Classification of transportation-based fuel and biofuels as reviewed by Naik et al. (23) and Baskar et al. (26).

Table 2.2. Countries that produce the highest levels of bioethanol, ranked according to production levels in 2014 (data adapted Renewable Fuels Association 2014, www.ethanolrfa.org/) (32)

Table 2.3. Composition of common lignocellulosic raw materials and wastes as reviewed by Kumar et al. (44) (weight $\%$ on dry biomass).

Table 2.4. The inhibitory effects of degradation by-products found in lignocellulosic hydrolysates on the yeast $S$. cerevisiae during $2 \mathrm{G}$ bioethanol production as reviewed by Field et al. (25)

Table 2.5. Difficulties in saccharification of cellulosic biomass resulting in large amounts of cellulolytic enzymes being required for CBP as reviewed by Yang et al. (100) and Hasunuma et al. (103).

Table 2.6. Categories and main characteristics of most important expression systems used for recombinant protein production as summarised in the review by Demain et al. (135).

Table 2.7. Secretion enhancing strategies in S. cerevisiae strains

Table 3.1. Plasmids and primers used for cellulase expression in natural S. cerevisiae strains.

Table 3.2. Cell specific total, secreted and percentage released S.f.Cel3A activity obtained from the $S$. cerevisiae transformants generated in this work.

Table 3.3. The quantification of heterologous S.f.cel3A, T.r.cel5A and T.e.cel7A genes expressed episomally and integrated into the genome of reference strain S288c and natural strains FIN1, YI13 and MF15.

Table 3.4. Maximum specific growth rate of the plasmid-containing reference strain S288c and natural strain YI13.

Table 3.5. Remarkable physiological and technological differences in the fermentation profiles of S. cerevisiae transformants expressing S.f.Cel3A on episomal plasmids in YPD medium under oxygen-limited conditions ${ }^{\mathrm{a}} \ldots 95$

Table 3.6. Co-culturing of $S$. cerevisiae transformants expressing heterologous cellulases in $25 \mathrm{~mL}$ medium containing $0.5 \mathrm{~g}$ Avicel (equivalent to $2 \% \mathrm{w} / \mathrm{v}$ ) as a sole carbon source. 101

Table 1A. All plasmids and primers used in this study.

Table 2A. Inhibitory cocktail consisting of the major inhibitory compounds in lignocellulosic hydrolsylate as described by Martin et al. (3)

Table 3A. Raw phenotypes scores, conditions, and stress doses used to make Figure 3.13. 138

Table 4A. Mode of action of secretion, endoplasmic reticulum and cell wall stresses used in this study. 141 


\section{List of Figures}

Figure 2.1. Schematic representation of the pathways for metabolic conversion of feedstocks into biofuels can be loosely divided into (a) feed pathways, which convert carbohydrate biomass into the central metabolic intermediates pyruvate and acetyl-CoA; and (b) product pathways, which converts these central intermediates into fuels. Image adapted from Fischer et al. (24)....

Figure 2.2. Schematic representation of enzyme-based cellulosic ethanol production process. After the initial pre-treatment step, enzyme hydrolysis and fermentation is either carried out separately (SHF) or simultaneous (SSF) by microbes to release monomeric and disaccharide sugars which are fermented into ethanol.

Figure 2.3. Schematic representation of biomass classifications, composition and chemical structures of (a) sugars, (b) starch and (c) inulin. Images taken from www.namrata.com.

Figure 2.4. Schematic representation of the (a) 3D structure of lignocellulose complex and (b) chemical structure of major compounds in plant cell walls (40). From the 3D image, the major components in lignocellulosic biomass include cellulose fibers (green), lignin molecules (brown wooden texture) and hemi-cellulose (light green). Image was taken from www.scisctyle.com, by Thomas Spletttoesser

Figure 2.5. Schematic representation of the inhibitor classes and the cellular energy consequences of lignocellulosic hydrolysate inhibitors. Presented are examples from three main classes of inhibitors and the ways cells can cope with these: efflux via pumps, detoxification via enzymes, and repair of the damage caused by the compounds. Image adapted from Piotrowski et al. (55).

Figure 2.6. Schematic representation indicating the mode of action of the cellulase enzymes of non-complexed cellulase systems in the hydrolysis of crystalline cellulose (www.cheminfo2010.wikispaces.com).

Figure 2.7. The ribbon structure of (a) Cel5A from T. aurantiacus, the closest homolog to T. reesei Cel5A (which is used in this present study). (b) Ribbon structure of native Talaromyces emersonii Cel7 A - similar to enzyme used in the present study with difference being a modified carbohydrate binding module (CBM). (c) Ribbon structure of S. fibuligera Cel3A (www.cazy.org).

Figure 2.8. Diagram of the conversion of lignocellulose to ethanol through hydrolysis and fermentation which can be performed separately, called separate hydrolysis and fermentation (SHF, indicated by broken arrows) or as simultaneous saccharification and fermentation (SSF). In consolidated bio-processing (CBP) all bioconversion steps are minimized to one step in a reactor using microorganisms. Diagram adapted from Dashthan et al. (128)........ 32

Figure 2.9. Challenges in different steps of bioethanol production process using lignocellulosic materials. (a) Environmental stresses in the bioethanol process that impact yeast. After pre-treatment of biomass, furan derivative, organic acids and phenolic compounds are produced during the release of sugar. Inhibitors may prevent fermentation; however both high temperatures and the ethanol produced as end product are known to inhibit growth. (b) Various factors affecting different steps of the process are responsible for the inefficient conversion of biomass at high solids content. Image adapted from Koppram et al. (192)....

Figure 2.10. Overview of host expression systems producing recombinant proteins including (a) biopharmaceuticals and (b) industrial enzymes as review by Demain et al. (150).

Figure 3.1. Schematic representation of the biological steps and ideal qualities a CBP host strain (text in blue) requires for bioethanol production in an enzyme-based process. During the enzyme hydrolysis (EH) step, the glucose contained in cellulose is liberated by the action of the cellulolytic enzymes (cellulases). The glucose is the converted to ethanol by fermenting microorganisms (bacteria or yeasts). The main advantage of the SSF process is that the continuous removal of the glucose by the microorganism (red arrow), which minimises the end product inhibition of the cellulolytic enzymes, therefore higher EH rates are obtained and better overall yields are reached. Another advantage of this process is that only one fermenter is used resulting in the subsequent reduction in costs.

Figure 3.2. Schematic representation of cellulase gene expressing plasmids. (a) Episomal plasmids pMUSD1/2/3 and (b) $\delta$-integration vectors pRDSD1/2/3 were used to screen S.f.Cel3A, T.r.Cel5A and T.e.Cel7A enzyme activity levels, respectively. The genes encoding the cellulases were cloned under the transcriptional control of the genes ENO1 promoter/terminator system and the marker gene kanMX in all cases. 
Figure 3.3. Heterologous (a) supernatant and (b) total cell specific $S . f$.Cel3A activities ranked based on supernatant enzyme ranking of natural strains in comparison to the reference strains S288c and MH1000, after $72 \mathrm{~h}$ expression in YPD. Values obtained were normalised with the dry cell weight (DCW) (c) Wild-type strains were confirmed to have negligible S.f.Cel3A I activity. Error bars indicate standard deviation from the mean value obtained from three biological repeats. The dotted line in (a) and (b) represents the average activity of the four reference strains...... 82

Figure 3.4. Spot test assays for the detection of (a) S.f.Cel3A and (b) T.r.Cel5A activities of S. cerevisiae transformants. Supernatant cultures were spotted onto SC agar plates supplemented with either esculin and ferric citrate, or CMC for $48 \mathrm{~h}$ and $24 \mathrm{~h}$, respectively. The wild-types did not show any extracellular Cel3A and Cel5A activity.

Figure 3.5. Comparison between secreted (blue bars) and total cell (orange bars) (a) S.f.Cel3A (b) T.r.Cel5A and (c) T.e.Cel7A cell specific activities of S. cerevisiae transformants. (d) Extracellular endogenous invertase activities were also evaluated. The error bars represent standard deviations from the mean. Values obtained were normalised with the dry cell weight (DCW) of the yeast after $72 \mathrm{~h}$ incubation. Wild-type strains demonstrated negligible activity on all substrates assayed (data not shown). The dotted line in (a) - (d) represents the average secreted activity levels of the four reference strains.

Figure 3.6. Comparison between total cell (orange bars) and extracellular (blue bars) (a) S.f.Cel3A (b) T.r.Cel5A and (c) T.e.Cel7 A activity levels of delta integrated transformants. Strains are arranged according to extracellular enzyme activity and compared to the reference laboratory strains S288c and Y294, and industrial strains MH1000 and Hoeg. The error bars represent standard deviations from the mean. 86

Figure 3.7. Supernatant (blue bars) and total (orange bars) recombinant cellulolytic activities normalised per relative plasmid copy number as determined by quantitative PCR. Transformants are ranked against the reference strain S288c expressing (a) T.r.cel5A, (b) T.e.cel7A and (c) S.f.cel3A genes from episomal plasmids. Each enzymatic assay and PCR was performed in triplicate. The error bars represent standard deviations from the mean from three biological repeats.

Figure 3.8. Genetic stability of $S$. cerevisiae transformants expressing the gene kanMX from (a) episomal plasmids and (b) integrated gene cassettes.

Figure 3.9. Ploidy determination of strains used in this study. (a) Yeast ascospores are indicated by the arrows. Cells were cultivated on sporulation media, then visualised with $100 \mathrm{X} 1.3$ objective using a differential interference contrast (DIC). (b) DNA content comparison of natural strains with a standard (haploid S288c strain). Fluorescent histograms of strains stained with propidium iodide (PI). The two peaks present in the histograms are a result of different cell populations. One peak represents the G1 and another (with twice the channel value) represents the $\mathrm{G} 2 / \mathrm{M}$ phase of the cell cycle..

Figure 3.10. Growth curves of the (a) S288c reference transformants and (b) YI13 transformants episomally expressing S.f.cel3A, T.r.cel5A and T.e.cel7A genes or an empty plasmid during the cultivation period. Absorbance was measured at $600 \mathrm{~nm}$. Mean values from triplicate experiments are shown and error bars indicate the standard deviation from the mean.

Figure 3.11. Fermentation and recombinant S.f.Cel3A activity profiles of natural strains compared to the reference strains MH1000 and S288c. Graphs display (a) ethanol titer and (b) residual glucose and (c) acetate produced at end point after $96 \mathrm{~h}$, and (d) supernatant and (e) total cell S.f.Cel3A activity, and (f) cell biomass over the period of 96 h. Error bars are standard deviations from the mean calculated from three biological triplicates. The percentages are calculated theoretical ethanol yields.

Figure 3.12. Co-culture fermentations of the (a) YI13 and (b) S288c episomal transformants expressing heterologous cellulase genes in $25 \mathrm{~mL}$ of YPD media containing $0.5 \mathrm{~g}$ Avicel after allowing the precipitate to settle for $24 \mathrm{~h}$. Co-culture fermentations of S. cerevisiae strains secreting S.f.Cel3A, T.r.Cel5A and T.e.Cel7A (without the external addition of BGL) were analysed using HPLC. (c) Levels of accumulated cellobiose measured for the strains at $48 \mathrm{~h}, 96 \mathrm{~h}$ and $168 \mathrm{~h}$. (d) Levels of ethanol measured for the strains at $48 \mathrm{~h}, 96 \mathrm{~h}$ and $148 \mathrm{~h}$. The values shown are the mean values of three repeats \pm standard deviations.

Figure 3.13. Inter-strain diversity of tolerance between natural and reference strains. The viability of seven natural strains, two reference strains MH1000 and S288c, and 21 recombinant strains cultivated under seven different environmental conditions was measured. Each row on the plot represents a different strain and each column indicates 
a given environment. Coloured boxes represent the average growth rate score of each strain cultivated in each environment, according to the key shown at the lower right [as adapted from Kvitek et al. (62)]. Episomal plasmid-containing strains are indicated with [ ] symbol, and integrated recombinants are indicted with _ symbol.

Figure 3.14. Viability analysis of two fold serial dilution of natural strains in plate viability assays after $24 \mathrm{~h}$. Resistance to $40 \mu \mathrm{g} / \mathrm{mL}$ DTT, $400 \mu \mathrm{g} / \mathrm{mL} \mathrm{CR,} 200 \mu \mathrm{g} / \mathrm{mL}$ sodium orthovanadate and $0.5 \mu \mathrm{g} / \mathrm{mL}$ tunicamycin was evaluated. Growth for all strains was compared to the reference laboratory strains S288c and Y294, and commercial strains MH1000 and Hoeg on YPD agar plates without inhibitor supplementation (Addendum, Figure 8A)... 109

Figure 4.1. Simplified scheme for the reverse metabolic engineering cycle and (encircled) approaches used at each step of the cycle. Image adapted from Salinas et al. (37).

Figure 1A. Empty (a) episomal plasmid and (b) integration vectors expressing kanMX gene.

Figure 2A. Dot plots with a gate encompassing the yeast population. Correlated measurements of FSC and SSC allow for differentiation of cell types in a heterogeneous cell population. The cell sub-populations are based on forward scatter light (FSC) vs. side scatter light (SSC). The use of gating is to restrict analysis to one population and is denoted by the black line on the scatter plots

Figure 3A. Histogram statistics. Statistical percentages of the negatives and the positives are calculated by comparing the event count with the gated events. For example in data file labelled MH1000 background there are 31,595 events, but 20,010 events were found inside the gate. We want the percentage of cells that are positive, so we would look at the \%Parent for MH1000 background: $20010 / 31595=63.33 \%$. Because the populations that represent a DNA histogram $(\mathrm{G} 0 / \mathrm{G} 1, \mathrm{~S}$, and G2+M) are not discrete, special algorithms are used. The area under the curve is integrated; then the percentages of each population present are calculated....

Figure 4A. Viability plate assay of natural strains compared to reference strains S288c and MH1000 cultivated for 7 days on YPD agar supplemented with $10 \%(\mathrm{w} / \mathrm{v})$ ethanol.

Figure 5A. Cell viability of $S$. cerevisiae transformants after $72 \mathrm{~h}$ cultivation under $\mathrm{G} 418$ selective pressure was measured using methylene blue straining technique (4). Measurements were simultaneously taken with the activity assays.

Figure 6A. Silver stained 10\% SDS-PAGE gels (a-c, f) and zymogram analysis (d \& e) of the secreted proteins from transformants expressing T.e.cel7A, T.r.cel5A and S.f.cel3A. (+) Denotes deglycosylated samples, (-) denotes untreated samples, $(\mathrm{Wt})$ denotes wild-type strains and [ ] denotes episomal transformants.....

Figure 7A. Cell biomass $\left(\mathrm{OD}_{600 \mathrm{~nm}}\right)$ of transformants grown in $\mathrm{YP}$ with $2 \%$ glucose over $72 \mathrm{~h}$ period.

Figure 8A. (a-b) Visual representation of Avicel precipitate (after $168 \mathrm{~h}$ ) and (c) chemical analysis of the supernatant of co-culture fermentations with and without externally added Novozyme 188 (+BGL). 140

Figure 9A. Analysis of 2-fold serial dilutions of natural strains with reference strains S288c, Y294, MH1000 and Hoeg in a plate viability assay after $24 \mathrm{~h}$. Resistance to $50 \mu \mathrm{g} / \mathrm{mL}$ Congo Red, $50 \mu \mathrm{g} / \mathrm{mL}$ sodium orthovanadate, 150 $\mu \mathrm{g} / \mathrm{mL}$ hygromycin $\mathrm{B}$ and $0.3 \mu \mathrm{g} / \mathrm{mL}$ tunicamycin (after $48 \mathrm{~h}$ ) were evaluated. using SC agar supplemented with various inhibitors 


\section{Chapter 1}

General Introduction, Problem Statement and Study Aims 


\section{Chapter 1: General introduction, problem statement and project aims}

\subsection{General introduction:}

Since 1970's, biofuel production has mainly focused on ethanol, which comprises $\sim 76 \%$ of the total biofuel consumption worldwide as of 2012 (data taken from International Energy Statistics, U.S Energy Information Administration, www.eia.gov/) (1). Second generation (2G) biofuel technologies such as cellulosic biomass conversion to ethanol are becoming an important alternative renewable fuel resources as is evidenced by a number of newly established pilot and commercial scale facilities (www.biofuelstp.eu/cellulosic-ethanol.html). This technology is particularly important because of its low-cost potential and abundance of substrate for example lignocellulosic biomass from agricultural waste products, forest and wood industries, and energy crops (2). However, this type of biomass used in cellulosic bioethanol production is not readily fermentable and expensive pre-treatments are required to increase access to the sugars within the biomass (3-6). After pre-treatment, the substrate is subsequently hydrolysed by cellulolytic enzymes to yield sugars, mostly glucose and xylose which are fermented to ethanol (7).

The conversion of lignocellulosic biomass to ethanol on a large scale does have several different technical challenges that must be overcome before it can become economically feasible (8). For the last 40 years, significant investment in research and development (from both private and public sectors) has been carried out in this area to ensure not only the reduction of inhibitors but also the development of fermenting organisms for their efficient conversion (4). In this context, the yeast Saccharomyces cerevisiae has been the subject of intensive research aimed at improving its fermentation and recombinant protein production capacity, which has resulted not only in the development of strains better adapted for lignocellulosic ethanol production but also in a better understanding of the biology of this model organism (9). However, important difficulties regarding the different factors that affect the performance of the yeast still need to be overcome (10).

It is widely recognised that fast, effective hydrolysis of pre-treated substrates requires the synergistic action of multiple hydrolytic and non-hydrolytic proteins, namely cellulolytic enzymes (11). Ideally, consolidated bio-processing (CBP) results in a single fermentative microorganism expressing multiple components of the cellulase enzyme system for efficient cellulose hydrolysis without the addition of external enzymes, resulting in decreased production costs. In order for full hydrolysis to occur, the synergistic actions of three core 
hydrolytic enzymes are needed: (a) endoglucanases (EGs) (b) exoglucanases, such as cellobiohydrolases (CBHs) and (c) $\beta$-glucosidases (BGLs). Despite a number of articles on cellulase gene expression in S. cerevisiae as reviewed by Yamada et al. (12), La Grange et al. (13) and Van Zyl et al. (10), recombinant yeast strains with the capability of the efficient enzyme production, cellulose saccharification, and ethanol production are not available today.

The aim of the work presented in this thesis was to evaluate and identify natural S. cerevisiae strains with higher heterologous cellulolytic activity compared to reference laboratory and industrial strains. A secondary aim was to identify strains with high tolerance to environmental stresses e.g., hydrolysate-derived inhibitors, high ethanol yields, high temperatures and fluctuation in osmolarity. These are the types of stressors encountered during the fermentation of lignocellulosic biomass that affect ethanol yield and productivity [as reviewed by Baskar et al. (14)].

As an introduction to the thesis, Chapter 2 gives a general description of the lignocellulosic feedstocks, the different steps of the ethanol production process, and some of the challenges associated with the fermentation of lignocellulosic biomass by $S$. cerevisiae, as well as heterologous cellulolytic enzyme production and secretion by $S$. cerevisiae. In Chapter 3, the natural strains are evaluated based on ability to express individual heterologous cellulases. Based on the levels produced, strains are further characterised based on the growth vigour, ploidy, fermentation profiles and tolerance to secretion and cell wall stresses. As a more integrative view of natural strains ability to cope in bioethanol environments, the viability of the strains to inhibitors and other environmental stresses were evaluated. This section introduces the concept of 'superior' strains demonstrating a balance between a high secretory phenotype and tolerance capabilities, whilst also highlighting the phenotypic diversity that exists between strains. Chapter 4 of the thesis summarises the main conclusions of the research and discusses some ideas for future studies to address some of the unanswered questions.

\subsection{Problem Statement}

The consolidation of saccharification and fermentation processes is a promising strategy (named consolidated bioprocessing $[\mathrm{CBP}]$ ), but requires the development of an ideal host microorganism capable of cellulose/hemicellulose hydrolysis and target chemical production $(10,15,16)$. Organisms that can hydrolyse these biomasses and, simultaneously, produce a compound of economic value such as ethanol at high titers and rates would significantly reduce the costs associated with the conversion process and improve overall process economics (6). 
By using engineering strategies, we can construct CBP-enabling microbes and develop a robust, ethanogenic microorganism, with the ability to express recombinant cellulolytic enzymes needed to hydrolyse the complex cellulosic biomass to fermentable, monomeric sugars (5).

To date, no ideal natural yeast has been identified with all the desired properties for CBP, although several candidates have been identified (17). The yeasts Pichia pastoris, Yarrowia lipolytica and Hansenula polymorpha have recently enjoyed more attention as hosts for the expression of recombinant proteins, demonstrating a number of advantages including high levels of protein production (18-20). However, these organisms have a low tolerance to ethanol, low ethanol yields, inactivity at low $\mathrm{pH}$, produce high levels of metabolic heat and have a high oxygen demand $(7,21)$. Therefore, the $S$. cerevisiae remains the host of choice due to its long history associated with fermentation, high ethanol yields and general robustness to environmental stresses encountered during industrial fermentations, although this species has a low recombinant protein secretion capacity $(13,22-27)$.

A variation of recombinant secreted proteins between $S$. cerevisiae strains have been shown by Gurgu et al. (28) and De Baetselier et al. (29) with reporter proteins S. fibuligera BGL and Aspergillus niger glucose being oxidase utilised, respectively. Moderate to low secretion levels of cellulases have been observed when using laboratory strains, particularly for the production of CBHs $(26,30)$, BGLs $(31,32)$ and EGs $(33-35)$. These features have led to the conclusion that secretion is a limiting factor for CBP with $S$. cerevisiae $(36,37)$. Therefore, production of cellulolytic enzymes represents a particular challenge and a logical focus for recombinant enzyme expression $(37,38)$. Several studies have managed to enhance protein secretion levels in $S$. cerevisiae $(27,39,40)$. Although these approaches have been successfully applied to enhance secreted levels of a variety of different reporter proteins, a wide range in secreted protein titers were observed $(24,41-44)$. The secretion enhancing abilities of many strains vary depending on the specific reporter protein characteristics and the properties of the host strain that may influence the protein's transit through the secretion pathway (20, 24, 45-47). Therefore, it is important to identity a strain(s) with a good general secretion capability of all three key cellulolytic enzymes utilised in CBP.

Cellulolytic enzyme secretion studies have been almost solely focused on heterologous expression in domesticated strains of $S$. cerevisiae. Although numerous studies have indicated that natural strains possess good ethanol production and tolerance to various industrial stresses 
of bioethanol processes (48-54), no studies, to our knowledge, have evaluated cellulolytic enzyme secreted activity levels and production capacity of natural $S$. cerevisiae strains. Exploring the natural biodiversity of yeast strains is a simple, yet very powerful way of selecting a strain(s) that contain desirable genetic traits that can be transferred to an industrial strain. In this study, we compared the cell-specific heterologous activities between natural strains of S. cerevisiae and reference strains (Section 3.3.1-3.3.3).

To date, the co-expression of all crucial enzymes, as well as the necessary enzyme dosage for efficient cellulose conversion produced by engineered yeasts has not yet been achieved, mainly due to the limited secretion capacity and potential metabolic burden related to extra enzyme synthesis and growth on cellulose (38). Although, the use of such a microorganism would be ideal, another proposed solution is a consortium of $\mathrm{CBP}$ microbes in an appropriate ratio for the expression of complementary enzymes instead of co-expressing all the enzymes in a single yeast $(12,55)$. Therefore, the ideal CBP-microbe would effectively secrete high titers of a single cellulolytic enzyme, thereby significantly reducing the titers of externally added enzymes. In this study, we evaluated co-culture fermentations on Avicel cellulose with transformants expressing individual cellulolytic enzymes (Section 3.3.7).

A clear difference in gene expression levels between natural, industrial, and laboratory strains of $S$. cerevisiae have been observed $(49,56,57)$. Several commercial strains, as well as natural strains of $S$. cerevisiae have demonstrated to be resistant to common industrial stresses such as high ethanol concentrations $(22,58)$, temperature shocks and osmotic stress $(59)$, as well as variation in ethanol yield and productivity (60). In this this study, we evaluated the strains' viability in the presence of environmental stresses (Section 3.3.8) as well as growth and fermentation vigour (Section 3.3.6-3.3.7).

\subsection{Aims and interests of the study}

The theory of developing a natural strain as a CBP organism prompted us to extend the expression of cellulolytic enzymes to natural $S$. cerevisiae strains. The strains used in this study were isolated from various vineyards along the winery, coastal regions of Western Cape, South Africa by Van der Westhuizen et al. (61). The overall aim of this study was to investigate the secreted and total activity levels of different cellulases transformed into the natural S. cerevisiae, in comparison to laboratory and industrial strains, to ascertain the most suitable heterologous host for the degradation of cellulose-based biomass and its conversion into bioethanol. 
This study will investigate natural strains that can maximise recombinant enzyme activity levels, in order to provide information on host strains required for $\mathrm{CBP}$ and may have future applications for heterologous protein secretion in general. By understanding the secreted activity patterns of natural strains, scientific research is one-step closer to creating an ideal host for economically advanced biofuel technology. This would not only give us insight on the variation of $S$. cerevisiae strains as expression hosts, but also provide valuable data on how efficiently these yeast strains cope with the secretion of each cellulolytic enzyme.

The specific aims of the present study were as follows:

(i) To evaluate and identify natural $S$. cerevisiae strains demonstrating superior total and secreted cell specific enzyme activity by producing key cellulolytic enzymes.

(ii) To compare natural, industrial and laboratory strains for desirable bioethanol production features, and identified strains which produced high ethanol titers and had innately high tolerance to various industrial stressors, such as inhibitors found in lignocellulosic hydrolysates.

(iii) To obtain strains more adapted to industrial fermentations, containing characteristics (genetic traits) suited for the biofuels industries, thereby extending the number of strains available to distilleries and bio-refineries. 


\subsection{References}

1. Von Grebmer K, Ringler C, Rosegrant MW, Olofinbiyi T, Wiesmann D, Fritschel H, Badiane O, Torero M, Yohannes Y. 2012. Global hunger index: the challenge of hunger: Ensuring sustainable food security under land, water, and energy stresses. Intl Food Policy Res Inst.70

2. Fujita Y, Ito J, Ueda M, Fukuda H, Kondo A. 2004. Synergistic Saccharification, and Direct Fermentation to Ethanol, of Amorphous Cellulose by Use of an Engineered Yeast Strain Codisplaying Three Types of Cellulolytic Enzyme. Applied and Environ. Micro. 70:12071212.

3. Den Haan R, van Zyl JM, Harms TM, van Zyl WH. 2013. Modeling the minimum enzymatic requirements for optimal cellulose conversion. Environ. Res. Lett. 8:025013.

4. Hasunuma T, Kondo A. 2012. Consolidated bioprocessing and simultaneous saccharification and fermentation of lignocellulose to ethanol with thermotolerant yeast strains. Process Biochem. 47:1287-1294.

5. Olson DG, McBride JE, Shaw A J, Lynd LR. 2012. Recent progress in consolidated bioprocessing. Curr. Opin. Biotechnol. 23:396-405.

6. Yamada R, Hasunuma T, Kondo A. 2013. Endowing non-cellulolytic microorganisms with cellulolytic activity aiming for consolidated bioprocessing. Biotechnol. Adv. 31:754-63.

7. Baeyens J, Kang Q, Appels L, Dewil R, Lv Y, Tan T. 2015. Challenges and opportunities in improving the production of bio-ethanol. Prog. Energy Combust. Sci. 47:60-88.

8. Hasunuma T, Kondo A. 2012. Development of yeast cell factories for consolidated bioprocessing of lignocellulose to bioethanol through cell surface engineering. Biotechnol. Adv. 30:1207-18.

9. Jeon E, Hyeon JE, Eun LS, Park B-S, Kim SW, Lee J, Han SO. 2009. Cellulosic alcoholic fermentation using recombinant Saccharomyces cerevisiae engineered for the production of Clostridium cellulovorans endoglucanase and Saccharomycopsis fibuligera beta-glucosidase. FEMS Microbiol. Lett. 301:130-6.

10. Van Zyl, W.H., Lynd, L.R., den Haan, R. and McBride, J.E., 2007. Consolidated bioprocessing for bioethanol production using Saccharomyces cerevisiae. In Biofuels (pp. 205235). Springer Berlin Heidelberg.

11. Wilson DB. 2009. Cellulases and biofuels. Curr. Opin. Biotechnol. 20:295-9.

12. Yamada R, Taniguchi N, Tanaka T, Ogino C, Fukuda H, Kondo A. 2010. Cocktail deltaintegration: a novel method to construct cellulolytic enzyme expression ratio-optimized yeast strains. Microb. Cell Fact. 9:32.

13. La Grange DC, Pretorius IS, van Zyl WH. 1996. Expression of a Trichoderma reesei betaxylanase gene (XYN2) in Saccharomyces cerevisiae. Appl. Environ. Microbiol. 62:1036-1044.

14. Baskar C, Baskar S, Dhillon RS. 2012. Biomass Conversion: The Interface of Biotechnology, Chemistry and Materials Science. Springer Science \& Business Media. 
15. Axelsson J. 2011. Separate Hydrolysis and Fermentation of Pretreated Spruce Separate Hydrolysis and Fermentation of Pretreated Spruce. SEKAB E-Technology, Linkoping, Sweden. Dissertation for $\mathrm{PhD}$.

16. Stephanopoulos G. 2007. Challenges in engineering microbes for biofuels production. Science 315:801-4.

17. La Grange DC, den Haan R, van Zyl WH. 2010. Engineering cellulolytic ability into bioprocessing organisms. Appl. Microbiol. Biotechnol. 87:1195-208.

18. Yu P, Zhu Q, Chen K, Lv X. 2014. Improving the Secretory Production of the Heterologous Protein in Pichia pastoris by Focusing on Protein Folding. Appl. Biochem. Biotechnol.

19. Celik E, Calık P. 2012. Production of recombinant proteins by yeast cells. Biotechnol. Adv. 30:1108-18.

20. Lynd LR, Van Zyl WH, McBride JE, Laser M. 2005. Consolidated bioprocessing of cellulosic biomass: An update. Curr. Opin. Biotechnol. 16:577-583.

21. Baumann K, Dato L, Graf AB, Frascotti G, Dragosits M, Porro D, Mattanovich D, Ferrer P, Branduardi P. 2011. The impact of oxygen on the transcriptome of recombinant S. cerevisiae and P. pastoris - a comparative analysis. BMC Genomics 12:218.

22. Li H, Wu M, Xu L, Hou J, Guo T, Bao X, Shen Y. 2015. Evaluation of industrial Saccharomyces cerevisiae strains as the chassis cell for second-generation bioethanol production. Microb. Biotechnol. 8:266-274

23. Van Rooyen R, Hahn-Hägerdal B, La Grange DC, van Zyl WH. 2005. Construction of cellobiose-growing and fermenting Saccharomyces cerevisiae strains. J. Biotechnol. 120:28495.

24. Kroukamp H, den Haan R, van Wyk N, van Zyl WH. 2013. Overexpression of native PSE1 and SOD1 in Saccharomyces cerevisiae improved heterologous cellulase secretion. Appl. Energy 102:150-156.

25. Den Haan R, Rose SH, Lynd LR, van Zyl WH. 2007. Hydrolysis and fermentation of amorphous cellulose by recombinant Saccharomyces cerevisiae. Metab. Eng. 9:87-94.

26. Ilmén M, den Haan R, Brevnova E, McBride J, Wiswall E, Froehlich A, Koivula A, Voutilainen SP, Siika-Aho M, la Grange DC, Thorngren N, Ahlgren S, Mellon M, Deleault K, Rajgarhia V, van Zyl WH, Penttilä M. 2011. High level secretion of cellobiohydrolases by Saccharomyces cerevisiae. Biotechnol. Biofuels 4:30.

27. Idiris A, Tohda H, Kumagai H, Takegawa K. 2010. Engineering of protein secretion in yeast: strategies and impact on protein production. Appl. Microbiol. Biotechnol. 86:403-17.

28. Gurgu L, Lafraya Á, Polaina J, Marín-Navarro J. 2011. Fermentation of cellobiose to ethanol by industrial Saccharomyces strains carrying the $\beta$-glucosidase gene (BGL1) from Saccharomycopsis fibuligera. Bioresour. Technol. 102:5229-36.

29. De Baetselier A, Vasavada A, Dohet P, Ha-Thi V, De Beukelaer M, Erpicum T, De Clerck L, Hanotier J, Rosenberg S. 1991. Fermentation of a yeast producing A. niger glucose oxidase: 
scale-up, purification and characterization of the recombinant enzyme. Nat. Biotechnol. 9:559561.

30. Den Haan R, Kroukamp H, van Zyl J-HD, van Zyl WH. 2013. Cellobiohydrolase secretion by yeast: Current state and prospects for improvement. Process Biochem. 48:1-12.

31. Cummings C, Fowler T. 1996. Secretion of Trichoderma reesei beta-glucosidase by Saccharomyces cerevisiae. Curr. Genet. 29:227-33.

32. Njokweni A P, Rose SH, van Zyl WH. 2012. Fungal $\beta$-glucosidase expression in Saccharomyces cerevisiae. J. Ind. Microbiol. Biotechnol. 39:1445-52.

33. Zhang W, Liu C, Wang G, Zhang K, Zou S, Zhang M. 2012. Comparison of the expression in Saccharomyces cerevisiae of endoglucanase II from Trichoderma reesei and endoglucanase I from Aspergillus aculeatus 7:4031-4045.

34. Du Plessis L, Rose SH, van Zyl WH. 2010. Exploring improved endoglucanase expression in Saccharomyces cerevisiae strains. Appl. Microbiol. Biotechnol. 86:1503-11.

35. Gupta S, Adlakha N, Yazdani SS. 2013. Efficient extracellular secretion of an endoglucanase and a Beta-glucosidase in E. coli. Protein Expr. Purif. 88:20-25.

36. Yan S, Wu G. 2013. Secretory pathway of cellulase: a mini-review. Biotechnol. Biofuels 6:177.

37. Den Haan R, van Zyl JM, Harms TM, van Zyl WH. 2013. Modeling the minimum enzymatic requirements for optimal cellulose conversion. Environ. Res. Lett. 8:025013.

38. Van Rensburg E, den Haan R, Smith J, van Zyl WH, Görgens JF. 2012. The metabolic burden of cellulase expression by recombinant Saccharomyces cerevisiae Y294 in aerobic batch culture. Appl. Microbiol. Biotechnol. 96:197-209.

39. Burgess-Brown N A, Sharma S, Sobott F, Loenarz C, Oppermann U, Gileadi O. 2008. Codon optimization can improve expression of human genes in Escherichia coli: A multi-gene study. Protein Expr. Purif. 59:94-102.

40. Munjal N, Jawed K, Wajid S, Yazdani SS. 2015. A Constitutive Expression System for Cellulase Secretion in Escherichia coli and Its Use in Bioethanol Production. PLoS One 10:e0119917.

41. Bitter GA, Chen KK, Banks AR, Lai P. 1984. Secretion of foreign proteins from Saccharomyces cerevisiae directed by a-factor gene fusions 81:5330-5334.

42. Van Zyl JHD, Den Haan R, Van Zyl WH. 2014. Over-expression of native Saccharomyces cerevisiae exocytic SNARE genes increased heterologous cellulase secretion. Appl. Microbiol. Biotechnol.

43. Teng D, Xi D, Zhang J, Wang X, Mao R, Zhang Y, Wang J. 2015. Multiple copies of the target gene enhances plectasin secretion in Pichia pastoris X-33. Process Biochem.

44. Ruohonen L, Toikkanen J, Tieaho V, Outola M, Soderlund H, Keranen S. 1997. Enhancement of protein secretion in Saccharomyces cerevisiae by overproduction of Sso protein, a late-acting component of the secretory machinery. Yeast 13:337-51. 
45. Linger JG, Adney WS, Darzins A. 2010. Heterologous expression and extracellular secretion of cellulolytic enzymes by Zymomonas mobilis. Appl. Environ. Microbiol. 76:6360-9.

46. Wang T-Y, Huang C-J, Chen H-L, Ho P-C, Ke H-M, Cho H-Y, Ruan S-K, Hung K-Y, Wang I-L, Cai Y-W, Sung H-M, Li W-H, Shih M-C. 2013. Systematic screening of glycosylation- and trafficking-associated gene knockouts in Saccharomyces cerevisiae identifies mutants with improved heterologous exocellulase activity and host secretion. BMC Biotechnol. 13:71.

47. Fitzpatrick J, Kricka W, James TC, Bond U. 2014. Expression of three Trichoderma reesei cellulase genes in Saccharomyces pastorianus for the development of a two-step process of hydrolysis and fermentation of cellulose. J. Appl. Microbiol. 117:96-108.

48. Lewis JA, Elkon IM, Mcgee MA, Higbee AJ, Gasch AP. 2010. Exploiting Natural Variation in Saccharomyces cerevisiae to Identify Genes for Increased Ethanol Resistance. Genetics, 186: 1197-1205.

49. Kvitek DJ, Will JL, Gasch AP. 2008. Variations in stress sensitivity and genomic expression in diverse S. cerevisiae isolates. PLoS Genet. 4:e1000223.

50. Ramos CL, Duarte WF, Freire AL, Dias DR, Cristina E, Eleutherio A, Schwan RF. 2013. Evaluation of stress tolerance and fermentative behavior of indigenous Saccharomyces cerevisiae 944:935-944.

51. Jin M, Sarks C, Gunawan C, Bice BD, Simonett SP, Avanasi Narasimhan R, Willis LB, Dale BE, Balan V, Sato TK. 2013. Phenotypic selection of a wild Saccharomyces cerevisiae strain for simultaneous saccharification and co-fermentation of $\mathrm{AFEX}^{\mathrm{TM}}$ pretreated corn stover. Biotechnol. Biofuels 6:108.

52. Mukherjee V, Steensels J, Lievens B, Van de Voorde I, Verplaetse A, Aerts G, Willems K, Thevelein JM, Verstrepen KJ, Ruyters S. 2014. Phenotypic evaluation of natural and industrial Saccharomyces yeasts for different traits desirable in industrial bioethanol production. Appl. Microbiol. Biotechnol.

53. Mart C, Jönsson LJ. 2003. Comparison of the resistance of industrial and laboratory strains of Saccharomyces and Zygosaccharomyces to lignocellulose-derived fermentation inhibitors 32:386-395.

54. Field SJ, Ryden P, Wilson D, James S A, Roberts IN, Richardson DJ, Waldron KW, Clarke T. 2015. Identification of furfural resistant strains of Saccharomyces cerevisiae and Saccharomyces paradoxus from a collection of environmental and industrial isolates. Biotechnol. Biofuels 8:33.

55. Baek S-H, Kim S, Lee K, Lee J-K, Hahn J-S. 2012. Cellulosic ethanol production by combination of cellulase-displaying yeast cells. Enzyme Microb. Technol. 51:366-72.

56. Carreto L, Eiriz MF, Gomes AC, Pereira PM, Schuller D, Santos M A S. 2008. Comparative genomics of wild type yeast strains unveils important genome diversity. BMC Genomics 9:524.

57. Borneman AR, Desany B A, Riches D, Affourtit JP, Forgan AH, Pretorius IS, Egholm M, Chambers PJ. 2011. Whole-genome comparison reveals novel genetic elements that characterize the genome of industrial strains of Saccharomyces cerevisiae. PLoS Genet. 7:e1001287. 
58. Almeida RM, Modig T, Petersson A. 2007. Increased tolerance and conversion of inhibitors in lignocellulosic hydrolysates by Saccharomyces cerevisiae 349:340-349.

59. Ruyters S, Mukherjee V, Verstrepen KJ, Thevelein JM, Willems K A, Lievens B. 2014. Assessing the potential of wild yeasts for bioethanol production. J. Ind. Microbiol. Biotechnol. $1-10$.

60. Pereira FB, Romaní A, Ruiz H A, Teixeira J A, Domingues L. 2014. Industrial robust yeast isolates with great potential for fermentation of lignocellulosic biomass. Bioresour. Technol. 161:192-9.

61. Van der Westhuizen TJ, Augustyn OPH, Pretorius IS. 2000. Geographical Distribution of Indigenous Saccharomyces cerevisiae Strains Isolated from Vineyards in the Coastal Regions of the Western Cape in South Africa 21:3-9. 
Chapter 2

Review of literature 


\section{Chapter 2: Review of literature}

\subsection{Bioenergy: Biofuels}

Bioenergy is defined as renewable energy that is made from materials derived from biological sources and has been rapidly emerging as a top priority in the international agenda as countries face the triple challenge of ensuring food security, energy security and sustainable development $(1,2)$. According to International Renewable Energy Agency (IRENA), if the realisable potential of all renewable energy technologies are implemented, renewable energy could account for $36 \%$ of the global energy mix by 2030 (www.irena.org). Significant attention towards renewable petroleum substitutes has been garnered, especially 'biofuels' which is defined as solid, liquid or gaseous fuels obtained from biological material (3). The South African government, as part of its efforts to alleviate the effects of the current energy crisis and diversify its energy industry, has proposed that biofuels form an important part of the country's energy supply $(4,5)$. The rationale for bioenergy developments in Africa differs from that in Western Europe, where the focus is on decreasing carbon dioxide emissions, or in the case of that in America, where reliance on fossil-fuels and energy security is the key issue $(6,7)$. The real benefit of a bioenergy sector in South Africa, and Africa in general, is in social development, whereby an innovative, inclusive and reliable energy platform can be created (5).

The idea for converting biomass-derived sugars to transportation biofuels was first proposed in 1970s (7-8). According to IRENA's Bioenergy Roadmap, by 2030, biomass is predicted to account for $60 \%$ of total final renewable energy use (www.irena.org). Today, however, biomass accounts for approximately $10 \%$ of total primary energy consumed globally, but not all of it is used in a sustainable manner (data retrieved from International Energy Statistics, U.S Energy Information Administration, www.eia.gov). Biomass, defined as any plant-derived organic matter, is the main source of energy for most of southern Africa (5, 9). Herbaceous and woody energy crops, agricultural food and feed crops, wood wastes and residues, aquatic plants, and other waste materials including some municipal wastes are abundantly available biomasses for sustainable energy (10). Biomass is the best choice to regulate the carbon cycle in the lithosphere, although it is often a challenging substrate due to its heterogeneous and chemically complex composition (9).

Currently, sugarcane in Brazil and starchy materials, for example, corn in USA, and wheat in Europe, are the main feedstocks for 1st generation (1G) biofuels (www.ethanolrfa.org). However, food insecurities in Africa are a key issue facing the continent (5), therefore there is 
a need to develop a bioenergy capacity that complements food production to ensure a sustainable future. In the last decade, lignocellulosic materials (2nd generation [2G] biofuel or lignocellulosic ethanol) and more recently algal biomass (3rd generation biofuel) have been suggested as more appropriate raw materials for conversion to biofuels (11).

\subsection{Biofuels according to technology}

\subsubsection{First generation (1G) biofuels}

Some of the most popular first generation biofuels include: biodiesel, biogas, bio-alcohols and syngas as reviewed by Naik et al. (12). Biodiesel is made mainly through a process called trans-esterification, which is the reaction of a fat or oil with an alcohol to form esters and glycerol (13). This fuel is similar to the mineral diesel and is produced after mixing the lipids with methanol and sodium hydroxide and replacing the glycerol moiety with a methylester (14). The chemical reaction thereof produces biodiesel. Batch and continuous processes are used for industrial purposes with a typical yield of 7.26-7.5 $\mathrm{Ggy}^{-1}$ and 8-125 $\mathrm{Ggy}^{-1}$ (15). However, the production costs of biodiesel are high due to the high cost of lipids (particularly virgin vegetable oil) and processing costs (14).

Biogas is mainly produced during the anaerobic digestion of the organic materials such as municipal waste, dairy waste, agricultural waste (such as fodder residue and manure) and energy crops such as maize (corn) (16). The ability to make biogas out of many different substrates is one of the main advantages of anaerobic digestion over other production processes like ethanol production (17). Although there is widespread acceptance of biogas technology, one of the main limitations is that lignin cannot be degraded by anaerobic bacteria (17), although this has been challenged (18).

Bio-alcohols are produced using enzymes and micro-organisms through the process of fermentation of sugar (19). Ethanol is one of the most common types of bio-alcohol whereas butanol and propanol are produced to a lesser extent (19). First generation bioethanol is currently the predominant biofuel and is manufactured from cane-derived sucrose and corn-derived starch (12). Using S. cerevisiae and other closely related yeast strains as hosts, industrial ethanol titers on sucrose are up to $93 \%$ of the stoichiometric maximum (11). Both continuous and batch system production is used, with residence times in the fermenters being $6-10 \mathrm{~h}(11,20)$. Although the process for production of ethanol from these sources is highly efficient, cellulosic (dry plant matter) biomass has a larger resource base than maize or sugar cane (12). 
In contrast to the biochemical conversion of biomass into bio-alcohols by enzymatic hydrolysis and fermentation, alcohols can also be produced by combination of thermochemical and fermentative pathways. Biomass can be gastified to synthesis gas (syngas) by heating it with a controlled level of oxygen. This syngas can be converted into ethanol either by catalytic conversion or with bacterial fermentation (21). Challenges, however, are up-scaling to a commercial scale, high capital costs and the low ethanol tolerance of the bacteria involved (22).

\subsubsection{Second generation (2G) biofuels}

Second generation $(2 \mathrm{G})$ biofuel technology is becoming an important alternative renewable fuel resource, because of its low cost and abundance of plant biomass, referring specifically to lignocellulosic biomass (plant dry matter) (12). Also known as advanced biofuels, $2 \mathrm{G}$ biofuels such as cellulosic ethanol production allows the organic carbon to be rapidly renewed as part of the carbon cycle (11). The cellulosic biomass is a polymeric source for glucose and xylose that can be converted by microbial fermentation into bioethanol (23), and it has been estimated that 419 billion litres of bioethanol could be produced each year from crop wastage (24). Among the ethanol production processes, there is special interest in the development of those based on enzymatic hydrolysis, since they are specific (25) and result in less effluent formation compared with acid hydrolysis (22).

A comparison between $1 \mathrm{G}, 2 \mathrm{G}$ and petroleum fuel production are made in Table 2.1. It is important to note that the structure of the biofuels does not change between generations, but rather the source from which the fuel is derived. As the replacement of fossil fuels takes place, the way to avoid the negative effects of producing biofuels from food supplies is to make lignocellulosic-derived fuels available within the shortest possible time. First generation (1G) bioethanol is based on non-recalcitrant, sugar rich feedstocks, hence, the technology required to extract the sugars is easier than for $2 \mathrm{G}$ bioethanol (which is still under development) $(12,22)$. 
Table 2.1. Classification of transportation-based fuel and biofuels as reviewed by Naik et al. (12) and Baskar et al. (24).

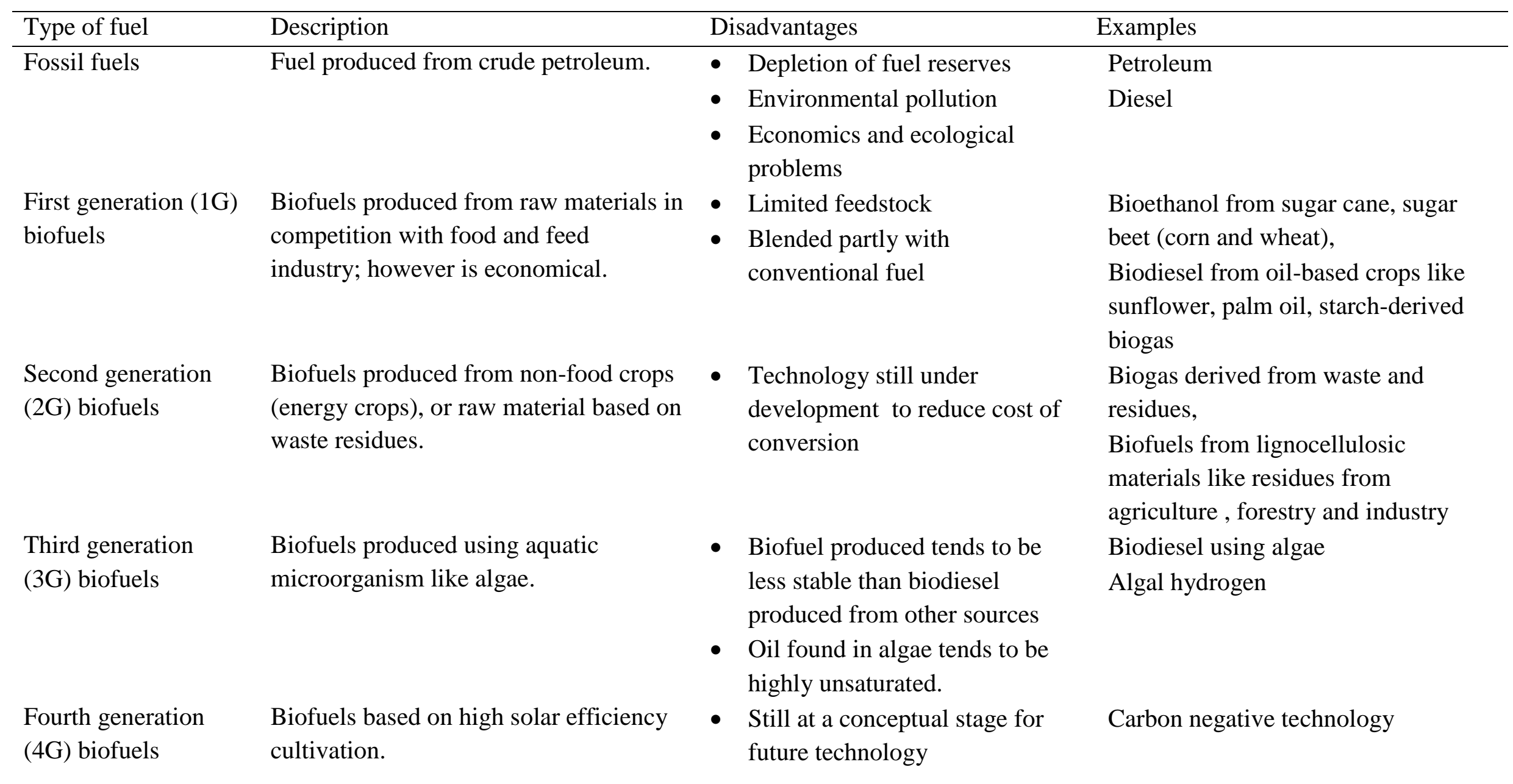


The synthesis of the different biofuels proceeds through common metabolic pathways and metabolic intermediates such as acetyl-CoA or pyruvate (25). The pathways can be effectively divided into "feed" pathways, which convert biomass to common metabolic intermediates which, in turn, can be converted into the chosen fuels (Figure 2.1).

(a)

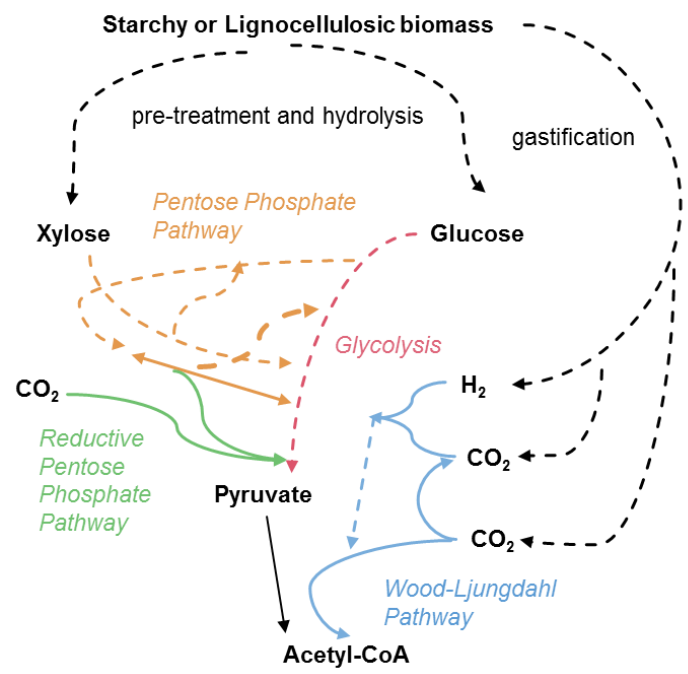

(b)

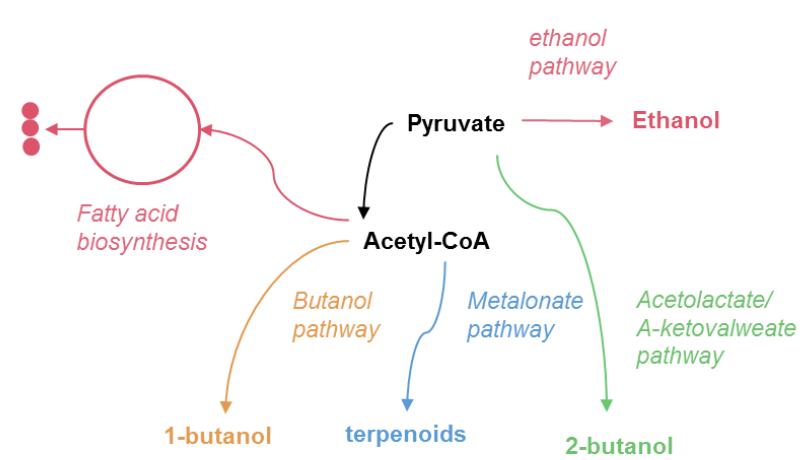

Figure 2.1. Schematic representation of the pathways for metabolic conversion of feedstocks into biofuels can be loosely divided into (a) feed pathways, which convert carbohydrate biomass into the central metabolic intermediates pyruvate and acetyl-CoA; and (b) product pathways, which converts these central intermediates into fuels. Image adapted from Fischer et al. (25).

\subsubsection{Cellulosic bioethanol production}

Ethanol was used in the first car engines and received a resurgence in appeal as a viable candidate to replace fossil fuels ever since the energy crisis in the 1970s (26). Bioethanol is also a very attractive biofuel to the automotive industry due to its miscibility with petroleum gasoline and can be used in low concentration blends $(<10 \%)$ in vehicles with no modifications (27). The use of ethanol blends has benefits to reducing water contamination and poses no significant adverse impacts on the public health or environment, generating lower emissions of $\mathrm{CO}_{2}$, non-combusted hydrocarbons, carbon monoxide, nitrogen oxides and volatile organic compounds $(28,29)$. Another advantage of using ethanol as a transportation fuel is that it offers high octane and high heat of vaporization, resulting in a greater energy output and improved net performance (27). The USA and Brazil are the largest 1G bioethanol producers, together contributing to $72,6 \%$ of the total bioethanol produced worldwide, with South Africa only 
ranked $33^{\text {rd }}$ in the world as of 2014 (Table 2.2) (according to the United States Energy Information Administration, www.eia.gov/).

Table 2.2. Countries that produce the highest levels of bioethanol, ranked according to production Table 2.2 Ranking of countries based on annual bioethanol production.

\begin{tabular}{ll}
\hline Country & Millions of gallons \\
\hline United States & 14,300 \\
Brazil & 6,190 \\
European countries & 1,445 \\
China & 635 \\
Canada & 510 \\
Thailand & 310 \\
Argentina & 160 \\
India & 155 \\
South Africa & 104 \\
\hline
\end{tabular}

levels in 2014 (data adapted Renewable Fuels Association 2014, www.ethanolrfa.org/) (30).

Source: RFA analysis of public and private estimates.

Second generation cellulosic bioethanol technology is still under development and one of the main technological impediments to a more widespread use of lignocellulose for production of biofuels and chemicals is the lack of economically feasible technologies $(3,30)$. There are four biologically mediated events that need to occur during the conversion of lignocellulose to bioethanol namely: production of depolymerising enzymes (cellulases and hemi-cellulases), hydrolysis of the polysaccharide constituents of pre-treated biomass, fermentation of hexose sugars present and fermentation of pentose sugars present (30) (Figure 2.2). Various designs in the strategies of the thermochemical conversion have been studied in the review by Petersen et al. (31) and tended to encompass alternative technologies for all the major conversion processes, where variants on the biological routes focused on the pre-treatment step (most economically and energy intensive step), enzyme production (costly production and use of large dosages), and fermentation (yields are low due toxicity and inability to co-ferment all the sugars) (32). 


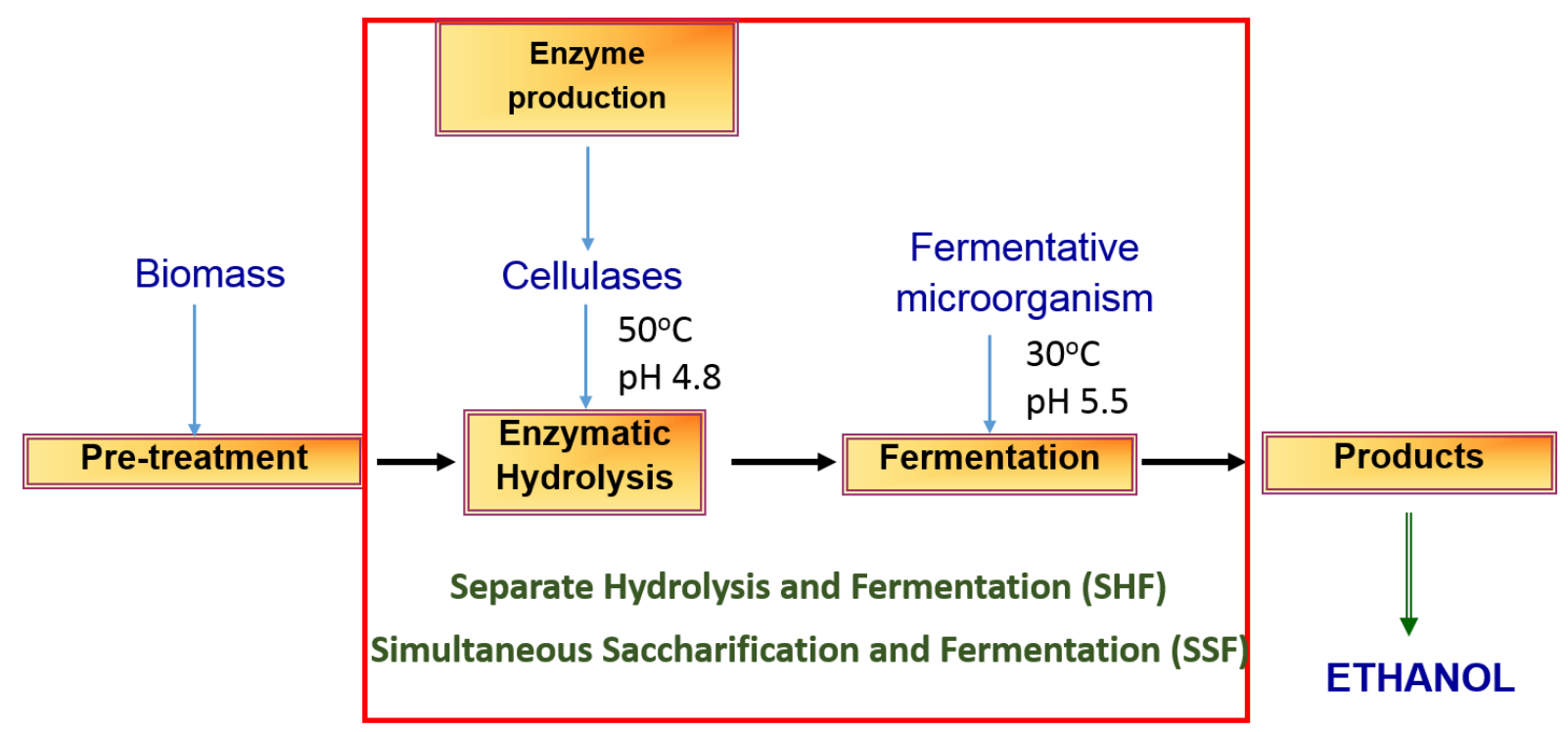

Figure 2.2. Schematic representation of enzyme-based cellulosic ethanol production process. After the initial pre-treatment step, enzyme hydrolysis and fermentation is either carried out separately (SHF) or simultaneous (SSF) by microbes to release monomeric and disaccharide sugars which are fermented into ethanol (32).

Separate hydrolysis and fermentation (SHF) is a central processing step in the biological scenarios, since it allows each step to be operated optimally (Figure 2.2) (32). The disadvantage of this process is the end product inhibition, whereby the glucose accumulation inhibits the cellulolytic enzymes causing low enzymatic hydrolysis yields (32). This last drawback can be solved by carrying out the competing technology, simultaneous saccharification and fermentation (SSF), where both stages occur simultaneously in the same vessel (32). The main advantage of this SSF process is that the continuous removal of the glucose by the microorganism, which minimises the end product inhibition, therefore higher enzyme hydrolysis rates are obtained and better overall yields are reached (32). Additionally, the SSF process would potentially reduce the capital costs, since the setup combines fermentation and hydrolysis reactions, the only capital expenditure should be one set of reactors instead of two (33). Experimental yields of ethanol from C5 and C6 sugars for SSF have generally been higher than SHF (32). The disadvantage of this process is the different optimal condition of enzyme hydrolysis and fermentation (32). As result, fairly robust microbes are required. Establishing economically feasible fermentation processes requires markedly increased final product titers due to the energy demands of product recovery steps, as well as the capital and production costs associated with the bio-refinery (34). In order to be economically viable, ethanol yield for $2 \mathrm{G}$ cellulosic bioethanol production needs to reach the 
bench mark of $40 \mathrm{~g} / \mathrm{L}$ in the fermentation broth so that distillation is economically viable (2, 15, 35-38). Achieving these high titers inevitably requires an increase in feedstock loading levels in SSF processes, which in turn, increases the concentration of toxic compounds released during pre-treatment and hydrolysis (39). In context of this study, we look at the development of highly fermentative, robust yeast with the ability to produce recombinant cellulolytic enzymes to hydrolyse cellulosic substrates and ferment to bioethanol.

\subsection{Feedstocks for biofuel types}

\subsubsection{Substrates for $1 \mathrm{G}$ technology}

First generation $(1 \mathrm{G})$ biofuels refers to the fuels that have been derived from food crops rich in starch like corn, wheat, animal fats, and vegetable oil (15). Some of the crops suggested for $1 \mathrm{G}$ biofuel technology in South Africa include canola, sunflower oil and soybeans (9). This type of biomass is classified by compositions and chemical structure in Figure 2.3. While this technology offers some carbon dioxide benefits and can help to improve domestic energy security, it relies on biomass from agricultural crops such as sugar cane and corn raising ethical issues regarding "food vs fuel"(12). Although this type of biomass is easily fermented to bioethanol, concerns exist about this technology including the impact it may have on biodiversity, land use, and competition with food crops (12).

(a)

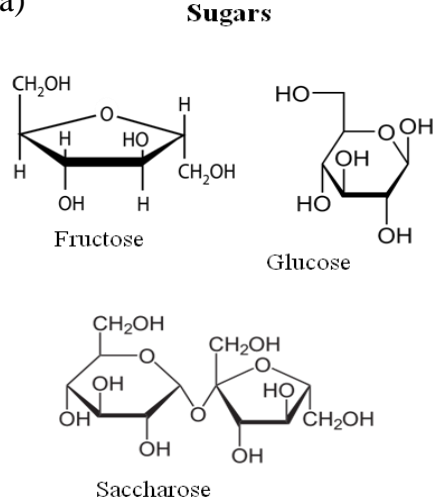

(b) Starch

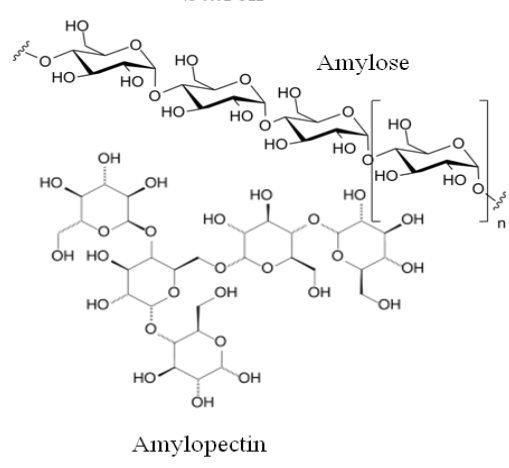

(c)

Inulin

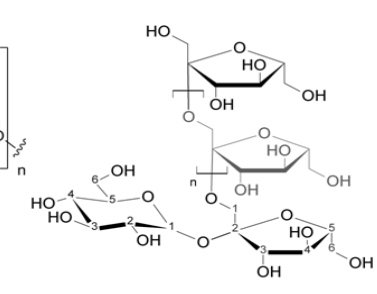

Figure 2.3. Schematic representation of biomass classifications, composition and chemical structures of (a) sugars, (b) starch and (c) inulin. Images taken from www.namrata.com. 


\subsubsection{Substrates for $2 G$ technology}

In general, lignocellulosic feedstocks are divided into three main categories: agricultural residues (e.g., crop residues, sugar canes bagasse), forest residues, and, herbaceous and woody energy crops (40). Agricultural by-products such as bagasse, corncob and stover, wood chips, wheat straw etc., can be used as substrate for biofuels (Table 2.3) (31). In South Africa, there is varying degrees of biomass resources that are available to establish a local bioenergy industry, such as agricultural residues (maize stover, sugarcane bagasse, wheat straw, sunflower stalks etc.), forestry and wood industry (forest residues, sawmill residue, paper and board mill sludge) and invasive plant species (5). These are abundant and attractive substrates for biofuel production by economically and environmentally sustainable fermentation processes.

Table 2.3. Composition of common lignocellulosic raw materials and wastes as reviewed by Kumar et al. (39) (weight $\%$ on dry biomass).

\begin{tabular}{llll}
\hline Lignocellulosic material & Cellulose (\%) & Hemi-cellulose (\%) & Lignin (\%) \\
\hline Hardwood stems & $40-55$ & $24-40$ & $18-25$ \\
Softwood stems & $45-50$ & $25-35$ & $25-35$ \\
But shells & $25-30$ & $25-30$ & $30-40$ \\
Corn cobs & 45 & 35 & 15 \\
Grasses & $25-40$ & $35-50$ & $10-30$ \\
Paper & $85-99$ & 0 & $0-15$ \\
Wheat straw & 30 & 50 & 15 \\
Sorted refuse & 60 & 20 & 20 \\
Leaves & $12-20$ & $80-85$ & 0 \\
Cotton seed hairs & $80-95$ & $5-20$ & 0 \\
Newspaper & $40-55$ & $25-40$ & $18-30$ \\
Waste papers (chemical pulps) & $60-70$ & $10-20$ & $5-10$ \\
Primary wastewater solids & $8-15$ & $\mathrm{~N} / \mathrm{a}$ & $\mathrm{N} / \mathrm{a}$ \\
Solid cattle manure & $1.6-4.5$ & $1.3-3.3$ & $2.5-5.7$ \\
Coastal bermugrass & 25 & 35.7 & 6.4 \\
Switchgrass & 45 & 31.4 & 12 \\
Swine waste & 6.0 & 28 & $\mathrm{Na}$ \\
\hline
\end{tabular}

All natural fibers essentially comprise of three groups of components: polysaccharides, including cellulose, hemicelluloses (xylan, etc.), pectin; lignin; and water- and solvent soluble compounds (e.g., waxes, minerals, etc.) (34). As depicted in Figure 2.4a, plant cell walls are composed of cellulose, hemi-cellulose, and lignin (36). Hemicellulose has a lower molecular weight than cellulose and its role is to connect lignin and cellulose fibers, while lignin holds together cellulose and hemi-cellulose fibers and gives support, resistance and impermeability 
to the plant (36). Cellulose (Figure 2.4b[i]) comprises of $\beta$-glucan linked by $\beta$-1,4,-glycosidic bonds and organised into crystalline fibers containing tightly packed microfibrils of approximately $30 \beta$-glucan chains containing amorphous regions (38). Cellulose has two distinct forms, one is a tightly packed crystalline homo-polymer, the other has non-organised soluble amorphous regions (2). Hemi-cellulose (Figure 2.4b[ii]) is a highly branched heteropolymer made up of hexose and pentose sugars as well as other sugar acids. While lignin (Figure 2.4b[iii]) consists of phenyl propanoids, it does not contribute to the carbohydrate pool (2). The distribution of cell wall components in the plant cell wall is shown in Figure 2.4b.

(a)

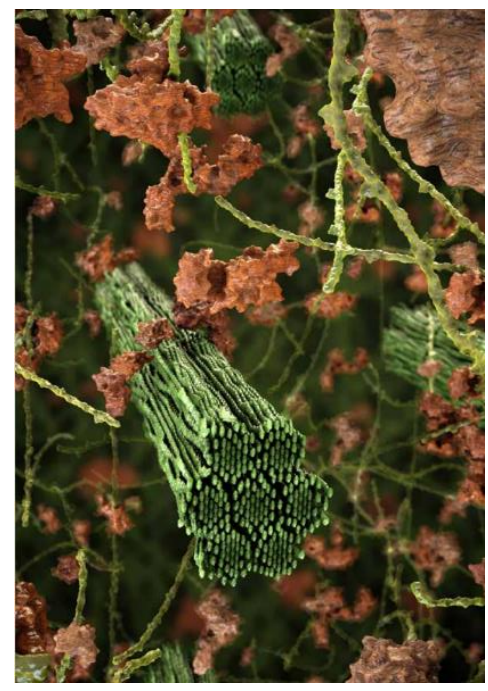

(b)

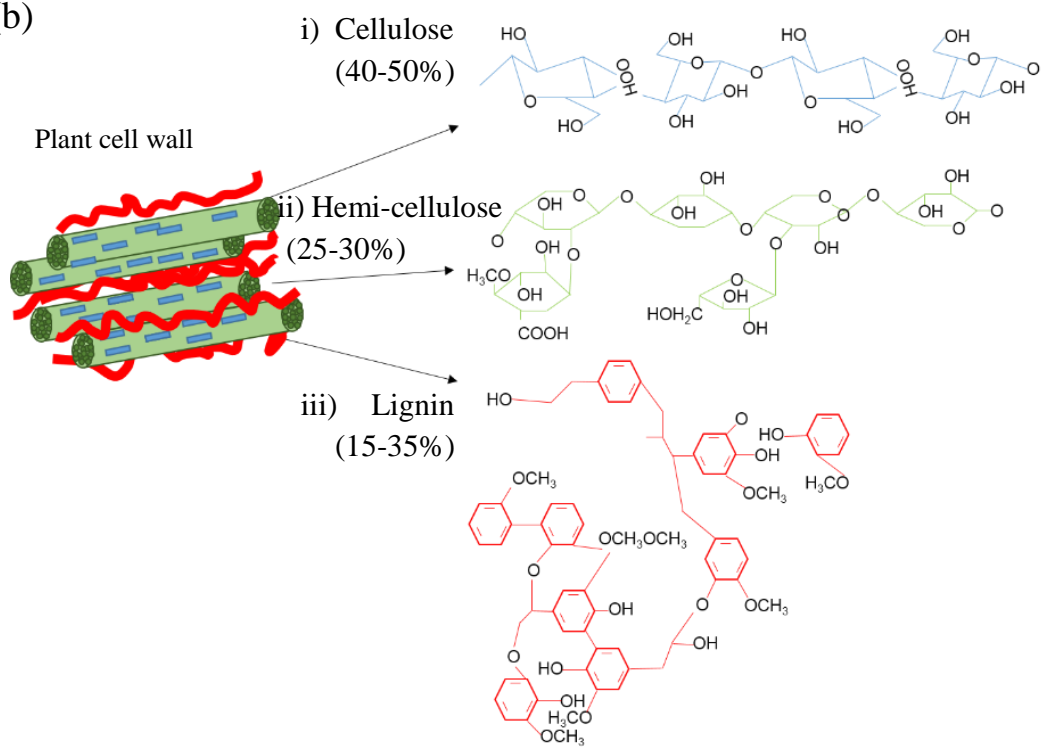

Figure 2.4. Schematic representation of the (a) 3D-structure of the lignocellulose complex and (b) chemical structure of major compounds in plant cell walls in plant cell walls (37). From the 3D image, the major components in lignocellulosic biomass include cellulose fibers (green), lignin molecules (brown wooden texture) and hemi-cellulose (light green). Image was taken from www.scistyle.com, by Thomas Splettstoesser.

The digestibility of cellulose present in lignocellulosic biomass is hindered by physiochemical, structural and compositional factors (39). One of the challenges for cellulosic ethanol production is that lignocellulosic materials have complex structures and are highly resistant to enzymatic hydrolysis to mono- and disaccharides (41). Cellulose is more difficult to convert into fermentable sugars than starch biomass, because (i) cellulose is highly crystalline and compact in nature, (ii) hemi-cellulose acts as a barrier for the cellulases to reach the cellulose (41), and (iii) the presence of lignin which links cellulose and hemi-cellulose together to form a recalcitrant barrier (42), making it difficult to degrade through microbial attack and 
hydrolysis by cellulolytic enzymes to its monomeric, fermentable sugars unlike starch substrates.

\subsection{Steps in $2 G$ ethanol production}

\subsubsection{Pre-treatment and inhibitors}

The recalcitrant nature of lignocellulosic feedstocks requires an initial pre-treatment step in order to alter its structure and make it more accessible for the cellulases enzymes during the enzyme hydrolysis step (43). Pre-treatment is necessary, but increases the overall process costs $(43,44)$. The pre-treatment itself solubilises little glucose and generally solubilises hemi-celluloses, although it depends on the pre-treatment method (45). Types of pre-treatments currently used include ammonia fiber explosion, chemical treatment, biological treatment, and steam explosion (39). The type of pre-treatment defines the optimal enzyme mixture to be used and the composition of the hydrolysis products (46). Glucose is by the far the most abundant in lignocellulosic biomass accounting for $30-50 \%$ of the biomass dry weight, while mannose and galactose are present in much lower amounts approximately $1-3 \%$ and $1-2 \%$ respectively (47). The xylose content of lignocellulose varies broadly depending on the source and averages between $18 \%$ of the dry weight while arabinose accounts for $\sim 3 \%$ (47). Therefore, it is important to note the composition of common agricultural residues and waste as seen in Table 2.3. After pre-treatment, the solid suspension is exposed to cellulolytic enzymes that digest the cellulosic and hemi-cellulosic biomass components to release the hydrolysis products, primarily six- and five-carbon sugars, respectively (along with acetic acid and lignin-derived phenolic by-products) (46).

Biomass pre-treatment and hydrolysis are areas that need drastic improvement (46). A disadvantage of pre-treatment of lignocellulosic biomass is the release and generation of a broad range of undesirable by-products as reviewed by Kricka et al. (47) (Figure 2.5). These by-products include acetic acid, formic and levulinic acids resulting from the hydrolysis of sugars (47). Other inhibitors such as furfural and 5-hydroxymethyl furfural (HMF) are produced from the degradation of pentoses and hexoses at high temperatures and pressures, whereas phenolics are a by-product of lignin degradation (47). However, there are many other hydrolysate inhibitors that have not been studied. In particular, the large number of aromatic compounds together with their diversity has complicated their study (48). 


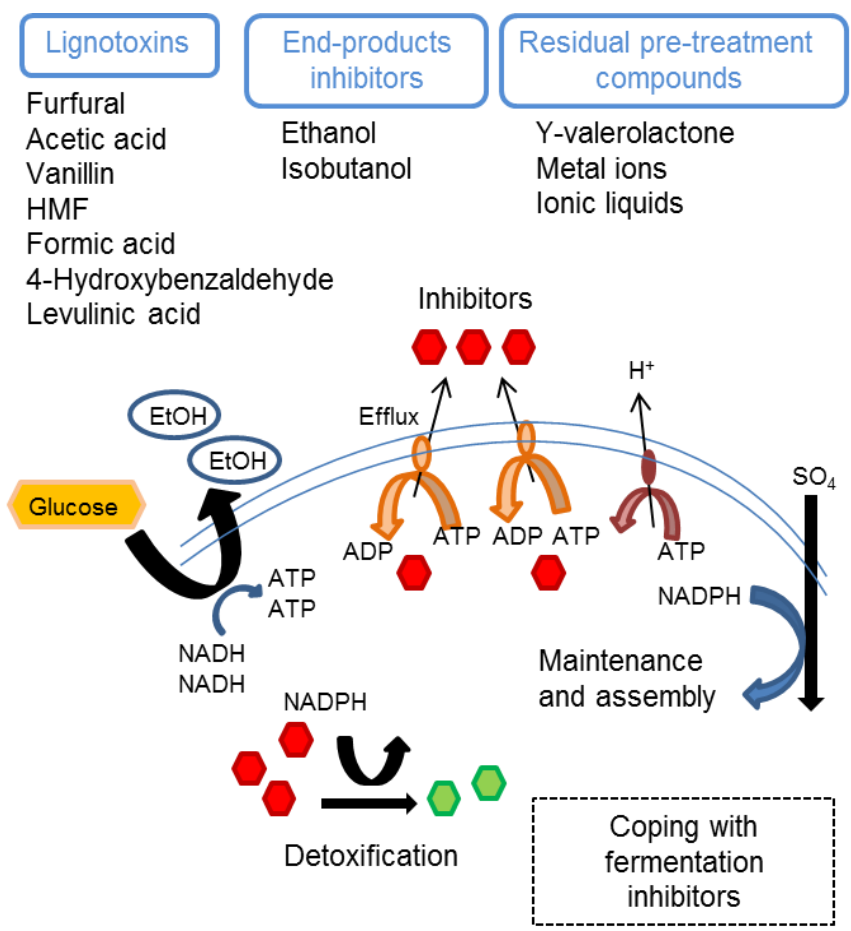

Figure 2.5. Schematic representation of the inhibitor classes and the cellular energy consequences of lignocellulosic hydrolysate inhibitors. Presented are examples from three main classes of inhibitors and the ways cells can cope with these: efflux via pumps, detoxification via enzymes, and repair of the damage caused by the compounds. Image adapted from Piotrowski et al. (49).

The degradation products produced by pre-treatment methods are inhibitory to microbial growth, enzymatic hydrolysis, and fermentation (as reviewed in Table 2.4). These inhibitory compounds can increase yeast sensitivity to osmotic stress and salt stress, specifically inhibiting the essential enzymes needed in carbon metabolism (50). These toxic effects lead to an increased lag phase during growth and reduced ethanol production at low furan concentrations with cell death at high concentrations (51). The pre-treated biomass often needs to be washed to reduce the concentration of inhibitors, however this decreases the overall saccharification yield by removing soluble sugars (39). Other detoxification strategies, including alkali or sulfite treatment, evaporation, anion exchange, and laccase addition have been developed to remove inhibitors or decrease their actions, although these methods are not economically or technologically feasible $(42,43)$. Therefore, the development of host microorganism(s) with innate high tolerance to these inhibitors is desirable. 
Table 2.4. The inhibitory effects of degradation by-products found in lignocellulosic hydrolysates on the yeast $S$. cerevisiae during $2 \mathrm{G}$ bioethanol production as reviewed by Field et al. (48).

\begin{tabular}{|c|c|c|}
\hline Inhibitor & Effect & Reference \\
\hline Furfural and & - Lag phase increase in lab strains. & $(47)$ \\
\hline HMF & $\begin{array}{l}\text { - Specific growth rate } \mu\left(\mathrm{h}^{-1}\right) \text { decreased in lab strain. } \\
\text { - Specific ethanol production rate }(\mathrm{g} / \mathrm{g} . \mathrm{h}) \text { decreased in } \\
\text { lab strain. }\end{array}$ & (43) \\
\hline Acetic acid & $\begin{array}{l}\text { - Biomass formation decreased in lab strain. } \\
\text { - Specific xylose consumption rates decreased in } \\
\text { xylose-consuming strains. }\end{array}$ & $(48)$ \\
\hline $\begin{array}{l}\text { Aromatic } \\
\text { (Phenolics) }\end{array}$ & $\begin{array}{l}\text { - Volumetric ethanol productivity (g/L.h) was reduced } \\
\text { in commercial strain. }\end{array}$ & (44) \\
\hline
\end{tabular}

\subsubsection{Cellulose hydrolysis by cellulolytic enzymes}

\subsubsection{Microbial cellulases and their industrial applications}

Research on cellulolytic enzymes (also known as cellulases) started as early as the 1950's as a result of their advantageous ability to convert lignocellulose to glucose and other soluble sugars (52). During the early 1990's extensive research into cellulases, hemi-cellulases and pectinases revealed its biotechnological potential that is still used today in many industrial processes, ranging from cotton and paper manufacturing to detergent enzymes, juice extraction and the biofuel industry (53). Cellulases are inducible enzymes synthesised by a large diversity of microorganisms including both fungi and bacteria during their growth on cellulosic materials (54). These microbes can be aerobic, anaerobic, mesophilic or thermophilic (54). In nature a large portion of wood degradation is carried out by white rot and soft rot fungi, both of which degrade cellulose and hemi-cellulose to more soluble carbohydrates by secreted synthesised enzymes (55). White rot fungi are Basidiomycetes and mineralise lignin, while soft rot, often Ascomycetes, do affect lignin but do not mineralise it $(55,56)$. A third class of aerobic wood degrading fungi, the brown rot fungi, are suggested to conduct a large part of wood degradation non-enzymatically (56). These wood-degrading enzymes secreted by fungi are mainly hydrolases, for example cellulases, xylanases, etc. (56-57). Homologous enzymes from yeasts have received less attention because they are considered to have lower performance and to be produced at lower yields (58). For industrial purposes, most commonly studied cellulolytic organisms are from the fungal species: Trichoderma, Humicola, Penicillium, and Aspergillus because of their capacity to produce the enzymes extracellularly and in large amounts as 
reviewed by Gautam et al. (54). Many fungi also secrete redox enzymes, such as manganese peroxidases and the copper-containing phenoloxidase, laccase, hydrogen peroxide-producing oxidases and cellobiose dehydrogenase as reviewed in detail by Hendriksson et al. (57). More recently, a new class of enzymes have been discovered that are capable of oxidising recalcitrant polysaccharides, namely lytic polysaccharides monooxygenases (LPMO) (59). It has been suggested that LPMOs have a beneficial effect in current commercial cellulose mixtures by having a significant impact on the efficiency of enzymatic biomass depolymerisation $(59,60)$. LPMOs are known to carry out oxidative cleavage of glycoside bonds crystalline structure of cellulose and chitin, thus boosting the activity of well-known hydrolytic depolymerising enzymes through synergy (80).

\subsubsection{Structure of cellulolytic enzymes}

The complexity of wood makes it an energy rich, but difficult substrate for degradation by microbes, therefore the enzymes involved in this process often have unusual and interesting features (3). Structurally, fungal cellulases are simpler compared to bacterial cellulase systems, called cellulosomes (61), and typically have two separate domains, namely: a catalytic domain (CD) and a cellulose binding domain (CBM) which is bound to the N-terminal of the CD by a short polylinker region (62). These domains are independently folding, structurally and functionally discrete units (62). The CBM is comprised of $\sim 35$ amino acids and the polylinker is rich in serine and threonine (62). The difference between free cellulase enzymes vs. cellulosomes complexes is the cellulosome-cohesion contains scaffolding and dockerincontaining enzymes which direct the entire cellulosome complex to the cellulosic material (61).

\subsubsection{Key cellulolytic enzymes required for consolidated bio-processing}

The Carbohydrate-Active Enzyme (CAZy) (www.cazy.org) database is a knowledge-based resource specialising in enzymes that build or catalyse complex carbohydrates and gluco-conjugates $(63,64)$. The classification reflects the structural features better than substrate specificity or evolutionary relationship e.g., cellulolytic enzymes have been grouped into sequence and structurally-related glycosyl hydrolase $(\mathrm{GH})$ families, thus providing a framework to understand the mechanistic properties of the enzymes (64). The enzyme commission number (EC) is associated with a recommended name for the prospective enzyme (64). 
The cellulase system consists of three main enzymes, namely endoglucanases (endo-1,4- $\beta$-glucanases; $\quad$ EC 3.2.1.4) (EGs), exoglucanases (exo-1,4- $\beta$-glucanases; EC 3.2.1.91) and $\beta$-glucosidases (1,4,- $\beta$-glucosidases; EC 3.2.1.21) (BGLs) (61). All three key enzyme types have similar CD which cleave $\beta$-glycosidic bond between glucose molecules, but differ in their binding substrates and substrate interacting domains that act to tether them to their polymeric substrate, and allows the processive degradation of cellulose by crawling along its strand (Figure 2.6) (52).

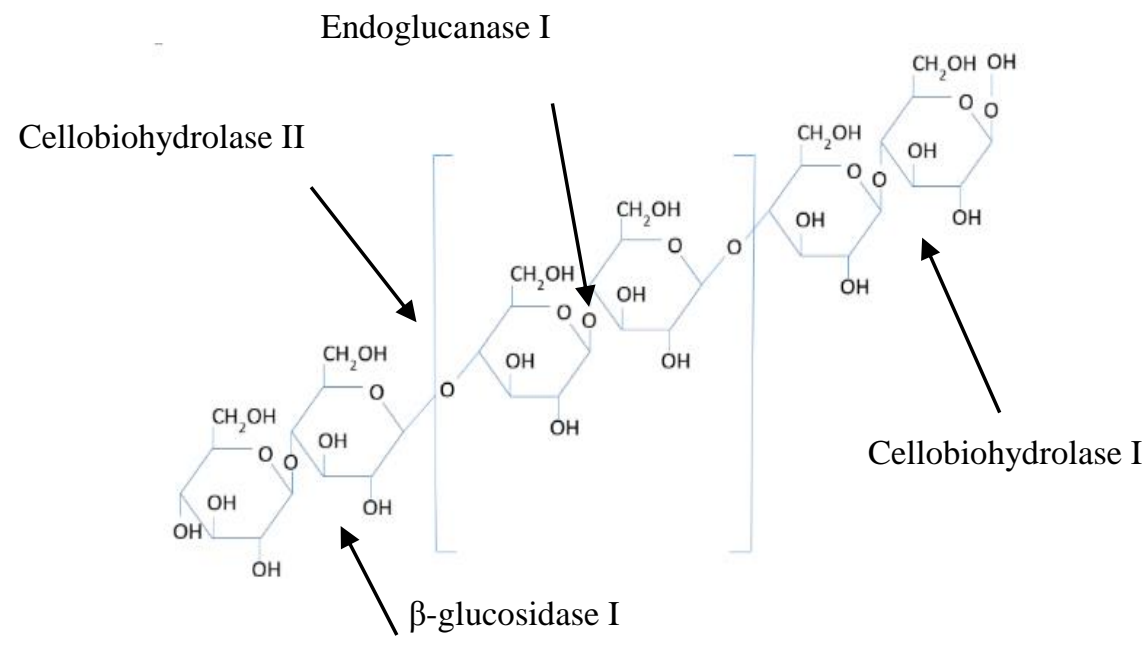

Figure 2.6. Schematic representation indicating the mode of action of the cellulase enzymes of non-complexed cellulase systems in the hydrolysis of crystalline cellulose (www.cheminfo2010.wikispaces.com).

Cellulose is hydrolysed to glucose monomers by the synergistic action of cellulases (58). Exoglucanases (cellobiohydrolases [CBHs]) progressively act on the reducing and non-reducing ends of cellulose chains to release short-chained cello-oligosaccharides that are further hydrolysed through endo-exo synergism with EGs (65). The exoglucanases disrupt the crystalline structure of cellulose and are, therefore, pivotal to the biomass conversion process (2). The BGL activity is the last step of the enzymatic degradation of cellulose degradation by hydrolysing soluble cello-oligosaccharides (e.g., cellobiose) to glucose (2). Cellobiose, consisting of two glucose molecules linked by $\beta$-1,4-glycosidic bonds, is an inhibitor of EGs and $\mathrm{CBHs}$, therefore BGL alleviates inhibition by cleaving cellobiose and producing glucose molecules (2)

The study focus of this project is on heterologous production of cellulolytic enzymes which will be described in more in detail in terms of their specific activities and structure in the next subsections. The enzymes BGLI (S.f.Cel3A), EGII (T.r.Cel5A) and CBHI (T.e.Cel7A) were 
chosen for analysis of total cell and secreted activity levels based on the fact that they represent the three main hydrolytic activities in a cellulase system and based on previous data relating to their known enzymatic activity and final cellular location $(2,66-70)$. With the exception of Saccharomycopsis fibuligera Cel3A (expressed from S.f.cel3A gene), the recombinant cellulases used in this study all preserved the native secretion signals of their proteins. Previous studies demonstrated that the use of foreign signals resulted in misdirection or retention of cellulolytic enzymes in the periplasmic space during secretion (71). This was not the case in S.f.cel3A gene expression, which has been shown to secrete well with xyn2 secretory signal (67).

\subsection{Endoglucanases (EGs, EC3.2.1.4)}

Endo- $\beta-1,4$ glucanase II (EGII) (also known as Cel5A), because it is grouped into family 5 of the glycosyl hydrolases [GHs]) is one of the major endoglucanases secreted by Trichoderma reesei (also known as Hypocria jecorina) (70). In this study, we use $T$. ressei Cel5A (T.r.Cel5A) as a reporter protein. With the exception of Cel12A, most T. reesei cellulases consist of a heavily $O$-glycosylated linker tethering a small carbohydrate binding domain (CBD) to a larger catalytic domain (72). Enzyme of the GH5 family show a common $(\beta / \alpha)$ TIM-barrel fold in which the catalytic acid/base and nucleophile are located on strands $\beta-4$ and $\beta-7$ of the barrel fold (72). The general topology bears a striking resemblance to Cel5A from Thermoascus aurantiacus (Figure 2.7a) (70).

(a)

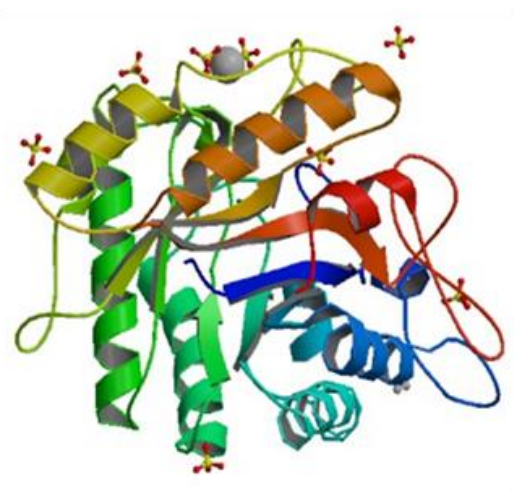

(b)

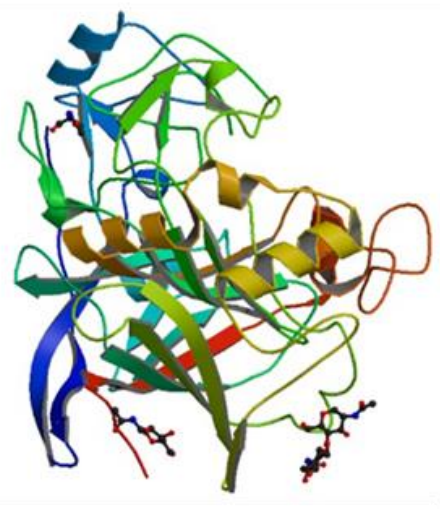

(c)

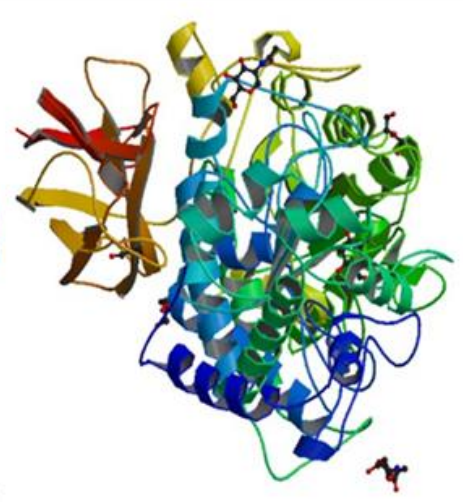

Figure 2.7. The ribbon structure of (a) Cel5A from T. aurantiacus, the closest homolog to T. reesei Cel5A (which is used in this present study). (b) Ribbon structure of native Talaromyces emersonii Cel7A - similar to enzyme used in the present study with difference being a modified carbohydrate binding module (CBM). (c) Ribbon structure of S. fibuligera Cel3A. Images taken from www.cazy.org. 
With a molecular weight of $48 \mathrm{kDa}$, EGII cleaves the more amorphous regions of cellulose, facilitating hydrolysis of cellulose by rapid depolymerisation, releasing cellodextrins of various lengths and producing more chain ends for processive enzymes to act upon (70). However, the EGII displays strict specificity towards cellulose and its derivatives e.g., hydrolysing cellotetrato cellohexaose, but prefers cleaving internal $\beta$-1,4-glycosidic bonds near the reducing ends of oligosaccharides producing glucose, cellobiose and cellotriose (73). Consistent with previously described endoglucanase structures, the crystal structure of a prevalent endonuclease II from T. reesei (also known as $H$. jecorina) reveals an active site containing a primary hydrophobic substrate binding groove and a series of hydrogen bond networks surrounding two catalytic glutamates (www.rcsb.org and www.expasy.org). The reported structure has stark differences between side-chain identity, loop regions, and the number of disulfides $(70,72)$. This structure has two $N$-glycosylation sites (www.netnglyc.org).

\subsection{Cellobiohydrolases (CBHs, EC3.2.1.91)}

Cellobiohydrolases (CBHs), from family 7 of $\mathrm{GHs}$ (Cel7A), are classified as processive enzymes as these enzymes hydrolyse cellulose chains from the ends in a continuous manner (74). Found exclusively in eukaryotic organisms, CBHs are also the major cellulases produced by the filamentous fungi such as $T$. reesei and Talaromyces emersonii. CBHs are needed for the hydrolysis of crystalline cellulose and subsequent release of cellobiose by acting on the reducing and non-reducing ends (75). The $\mathrm{CBM}$ is attached to the $\mathrm{C}$-terminus through a linker, and enhances the hydrolysis of crystalline cellulose (66). In this study, we used a T.r-T.e CBH chimera which contains the catalytic domain from T. emersonii Cel7A and the linker and carbohydrate binding domain from T. reesei Cel7A (68). For simplicity, T.r-T.e CBHI is referred to as T.e.Cel7A in text.

The crystal structure of T. emersonii Cel7A (Figure 2.7b) reveals a $\beta$-sandwich fold, where altogether six loops extend from the $\beta$-sandwich and participate in forming an enclosed tunnellike active site for cellulose binding and hydrolysis (www.expasy.org). The active site tunnel is roughly $50 \AA$ long and can accommodate 9-10 substitutes for the glycosyl units of a cellulose chain $(75,76)$. The catalytic amino acids (three carboxylic acids) are located near one end of the tunnel and allow release of the product (mainly cellobiose, a disaccharide) from the reducing end of the cellulose chain (76). This protein has three putative $N$-glycosylation sites (www.netnglc.org). 


\subsection{Glucosidases (BGLs, EC3.2.1.21)}

$\beta$-Glucosidases (BGLs) constitute a major group among GHs, mainly hydrolyses cellobiose which inhibits other cellulase enzymes (77). They have been the focus of much research recently because of their important roles in a variety of fundamental biological and biotechnological processes (99). They belong to families 1 and 3 of the GHs and hydrolyse either $O$-linked $\beta$-glycosidic bonds ( $\beta$-D-glucoside glucohydrolase, EC.3.2.1.21) or $S$-linked $\beta$-glycosidic bonds (myrosinase, EC.3.2.3.1) (www.expasy.com). Being the final step in the cellulose hydrolysis process, BGLs produce glucose from hydrolysing cellobiose and other longer cello-oligomers produced by EGs and $\mathrm{CBHs}$ (78). The hydrolysis of longer cello-oligosaccharides, such as aryl- and alkyl- $\beta$-D-glucosidases shows this enzyme's broad substrate specificity, however this enzyme prefers substrates with a larger number of available chain ends, with the pocket-like active site favouring the $\beta$-O-glycosidic bond at the

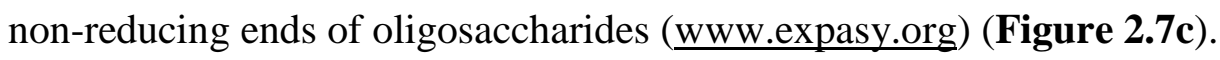

In this study, we use S. fibuligera BGLI (S.f.Cel3A) as reporter protein. This enzyme falls under the glycosyl hydrolase family 3, hence its alternative nomenclature, Cel3A (www.cazy.org). A portion of the $S . f . C e l 3$ A remains attached to the cell wall (cell wall bound) of the yeast cell $(67,71,79,80)$, which is an important parameter to consider when determining the enzyme activity in culture media. The $S$. $f$.Cel3A also contains 14 putative $N$-glycosylation sites (www.expasy.org and www.netnglyc.org).

\subsubsection{Enzyme hydrolysis}

The $2 \mathrm{G}$ cellulosic ethanol production process has difficulties in lignocellulose breakdown resulting in costs being driven up due to cellulose hydrolysis $(1,78)$ (as summarised in Table 2.5). Enzymatic hydrolysis of cellulose consists of three steps: absorption of cellulases to the surface of cellulose, hydrolysis of cellulases, and desorption of cellulases (as reviewed by Pandey et al. (81). Enzymatic hydrolysis of cellulose is one of the bottlenecks in the commercialisation of the process due to low hydrolysis rates and cost of enzymes (78). Theoretically, cellulase enzymes reactions should have high specificity that would result in the efficient hydrolysis of cellulose to glucose (78). The cellulolytic enzyme itself is less specific compared to amylases (100-fold less specific), therefore the dosage amount required for complete cellulose hydrolysis is much higher (82). 
Table 2.5. Difficulties in saccharification of cellulosic biomass resulting in large amounts of cellulolytic enzymes being required for CBP as review by Yang et al. (78) and Hasunuma et al. (1).

\begin{tabular}{|c|c|c|}
\hline Factors & Mechanism & Ref. \\
\hline $\begin{array}{l}\text { Complex enzyme } \\
\text { substrate interactions }\end{array}$ & Irreversible and non-specific absorption of cellulolytic enzymes. & $(1,83)$ \\
\hline Enzyme-related factors & $\begin{array}{l}\text { Thermal instability of cellulases. } \\
\text { Product inhibition (e.g., xylan, glucose and lignin derivatives, especially xylan oligomers, were } \\
\text { reported to show different degrees of inhibition of enzymatic hydrolysis. } \\
\text { Enzyme inactivation. } \\
\text { Enzyme slowing down. } \\
\text { Inactivation of key components of cellulase complex. }\end{array}$ & $\begin{array}{l}(84) \\
(43,85) \\
(86) \\
(87) \\
(88)\end{array}$ \\
\hline Substrate-related factors & $\begin{array}{l}\text { Substrate transformation into less digestible form, heterogenous structure of the substrate. } \\
\text { Cellulosic characteristics (e.g., size, structure, crystallinity, degree polymerization and accessible } \\
\text { surface area) were shown to affect cellulase absorption, synergism and processitivity. } \\
\text { Low water and high viscosity of pre-treated materials. }\end{array}$ & $(89)$ \\
\hline Cellulase components & $\begin{array}{l}\text { Different cellulase components have been shown to have different adsorption capacities and activities } \\
\text { for cellulose. } \\
\text { Cross-linking among chains of cellulose fibers, coupled with their being imbedded in a matrix of } \\
\text { polysaccharides involving lignin and other polymers, provides extra rigidity in native plant cell walls } \\
\text { but complexity for enzymatic digestion. }\end{array}$ & $\begin{array}{l}(90) \\
(91)\end{array}$ \\
\hline $\begin{array}{l}\text { Derived insoluble matter } \\
\text { distribution effects }\end{array}$ & $\begin{array}{l}\text { Deacetylation was reported to improve cellulose digestibility. } \\
\text { Hemicellulose (e.g., xylan) and lignin removal appeared to improve cellulose digestibility, but some } \\
\text { pre-treatment methods are effective without removing either (e.g., ammonia fiber expansion). } \\
\text { Solid lignin could cause non-specific binding of cellulases. } \\
\text { Hemi-cellulose sugars (e.g., xylan mono/oligomers) have inhibitory effects on cellulases. }\end{array}$ & $\begin{array}{l}(92) \\
(39) \\
(93)\end{array}$ \\
\hline
\end{tabular}


In practice the yields of glucose are influenced by external factors that affect both the rate and extent of hydrolysis (78). These factors include the cellulose structure and complex enzymesubstrate interactions during hydrolysis as reviewed by Yang et al. (78). It is known that the hydrolysis rate progressively declines over time due to a range of substrate and enzyme related factors, such as end-product inhibition, the irreversible and non-specific absorption of cellulolytic enzymes onto the substrate, as well as the inactivation of key components of the cellulase complex as reviewed by Pandey et al. (81). Substrate concentrations are also one of the main factors that affect the yield and initial rate of enzymatic hydrolysis of cellulose (83). The extent of hydrolysis has also been shown to influence both the surface area available for enzyme substrate interaction, which is determined by cellulose pore size and the shielding effects of lignin and hemicelluloses (76). Ma et al. (83) revealed an inverse relationship in which an apparent decrease in the hydrolysis rate of $T$. reesei $\mathrm{CBH} 1$ was observed with increasing surface density of cellulose substrate.

There are various ways in which cellulase effectiveness can be enhanced. For example, the low specific activity of cellulolytic enzyme preparations and drop in saccharification rates during hydrolysis has led to the requirement for high cellulase loadings (78). This has resulted in high enzyme production costs contributing to the overall cost for $2 \mathrm{G}$ bioethanol production (3). A considerable amount of research is now focused on enzymatic and inhibitory mechanisms associated with the cellulase complex $(86,88,89)$. The supplementation with BGLs during hydrolysis, and removal of sugars during hydrolysis by ultra-filtration or SSF are some of the methods that have been developed to reduce inhibition of hydrolysis (94). Consolidated bio-processing (CBP) is one of the strategies that have been proposed as a solution to reduce enzyme cost contribution, whereby a single microorganism capable of both producing biomass hydrolysing enzymes and fermenting the released sugars to ethanol e.g., a fermentative microbe is engineered with a cellulolytic system (95). Previous studies have used a variety of strains and conditions to express recombinant cellulolytic enzymes, which is problematic since the impact of the secretion of recombinant proteins on gene expression is influenced by the genetic background of the host strains $(79,96,97)$. Therefore, the choice of host for heterologous expression of cellulase genes for CBP is an important factor to consider and discussed in later subsections of this chapter.

There is also an inherent difficulty in developing recombinant strains for the metabolism of cellulose as a sole carbon source (3). As discussed previously, cellulose is a large 
polysaccharide that needs to be hydrolysed in the extracellular media to produce glucose, which is then transported to the cell to be fermented (74). However, this creates a "chicken and the egg" situation because in order to produce cellulases for hydrolysis, cell growth is needed, which is limited due to the lack of fermentable sugars freely available during the start of fermentation (43). The construction and utilisation of cellulosomes tethered to the cell surface has provided a partial solution, however, even with this new system, cellulose hydrolysis has not substantially improved compared to freely secreted enzyme systems as reviewed by Wieczorek et al. (98). Another solution is genetically modifying industrial strains with xylose (and arabinose) pathways, to allow a broader range of sugars to be metabolised (61).

\subsubsection{Synergism concept}

Synergism is the phenomena whereby a mixture of enzymes exhibit higher specific activity compared to the sum total of the individual enzymes (58). This effect is common amongst cellulases, with the effect more prominent when acting on crystalline cellulose (58). To date there are four types of synergy that have been described with regards to cellulolytic enzymes:(i) endo-exo synergy can be created through the simultaneous action of an EG and a CBH resulting in cellulose degrading to cellobiose and cello-oligosaccharides (87), ii) exo-exo synergy can be between two CBHs acting on the reducing and non-reducing chain ends of cellulose (99), (iii) synergistic interaction between exo-glucanase and BGLs which remove cellobiose which inhibits the first two enzymes (100), and (iv) intramolecular synergy between CBMs and catalytic domains (101).

Synergistic expression of cellulase genes for degradation of cellulosic substrates has been demonstrated by various studies (7, 99-101), and growth on cellulose has been accomplished through co-expression of cellulase genes in S. cerevisiae (102). Various hypotheses have been proposed to explain the mechanism of synergistic interactions, however research has shown that the extent of cellulase synergism is influenced by enzyme concentration and the nature of the lignocellulosic substrate (65), therefore synergism is dependent on the ratio of individual enzymes, the substrate saturation and the properties of the substrate (99). It has been demonstrated that the synergistic cooperation not only substantially enhances the hydrolysis content, but also dramatically reduces the required cellulase dosage (in some cases 7-fold) needed to achieve reasonable cellulose hydrolysis yield (65). In order to find a solution to the optimal ratios of different types of cellulases, Yamada and co-workers (103) developed a cocktail of cellulase gene cassettes which were introduced into the S. cerevisiae chromosome 
simultaneously in one step using a single selection marker and the genes $T$. reesei cel7 $B$ and cel7A, and Aspergillus aculeatus cel3A. After three rounds of cocktail delta integration, Yamada and co-workers (103) were able to create a strain with half the number of cellulase genes than a conventional strain but twice the activity on PASC due to optimised activity ratios.

\subsubsection{Fermentation and process configurations}

Generally, two process configurations, SSF and SHF, have been compared as methods to produce bioethanol from lignocellulosic materials (Figure 2.8) (32, 33, 104, 105). The SSF process was first studied in 1977 by Takagi et al. (107) for cellulose conversion to ethanol, whereby both enzyme and yeast were added to the same bioreactor, allowing one-step conversion. The SSF typically lasts 3-6 days, with the cellulose hydrolysis being the slower and costly step, and the product of SSF is a dilute ethanol stream of 4-4.5\% from which ethanol is separated by distillation (32-33).
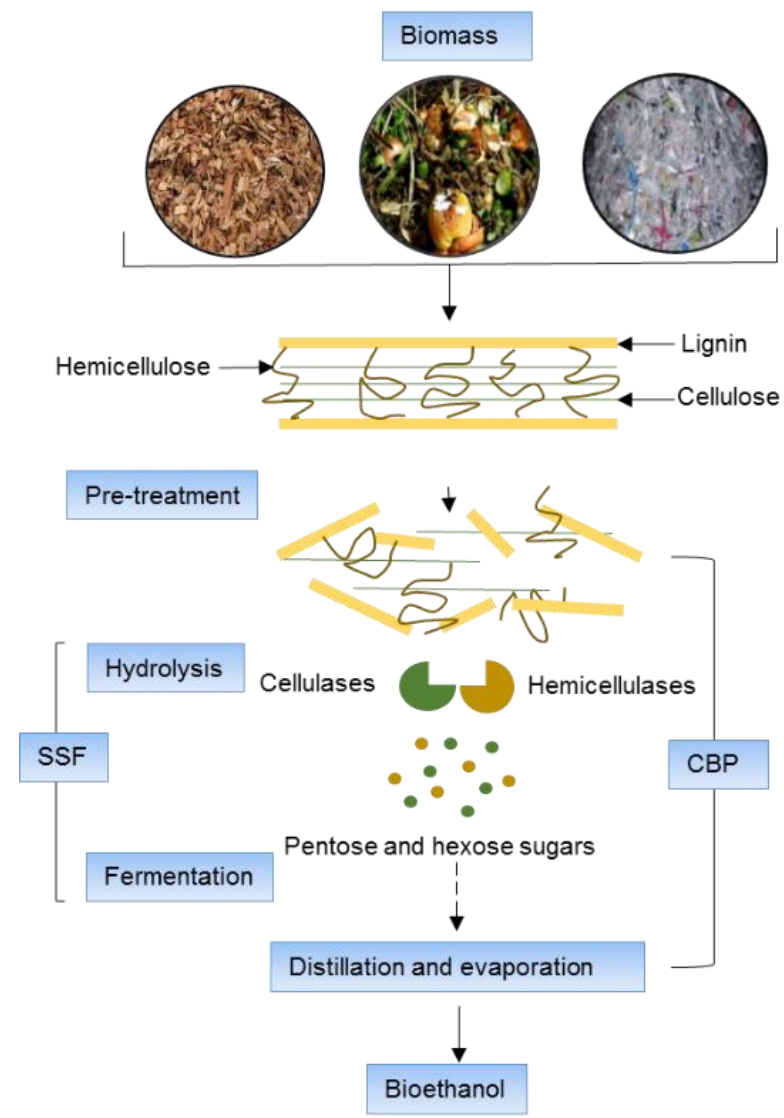

Figure 2.8. Diagram of the conversion of lignocellulose to ethanol through hydrolysis and fermentation which can be performed separately, called separate hydrolysis and fermentation (SHF, indicated by broken arrows) or as simultaneous saccharification and fermentation (SSF). In CBP, all bioconversion steps are minimised to one step in a reactor using microorganisms. Diagram adapted from Dashthan et al. (106). 


\subsubsection{Environmental stresses in $\mathrm{CBP}$ and general stress response}

Compared to beer, bread, and wine fermentations, the bioethanol fermentation environment is a relatively new man-made fermentation process consisting of very specific challenges, which differ greatly from conditions commonly encountered in traditional food and beverage fermentation, including the presence of inhibitory compounds that are formed during lignocellulose hydrolysis (Figure 2.9) (49, 108). The conditions encountered in bioethanol fermentations pose specific challenges, including varying ethanol concentrations, high temperatures and the presence of lignocellulose-derived inhibitors (109). In addition, yeasts are exposed to stresses in sequential and multiple manners (110). Under severe stress conditions, it is known that yeasts fermentation is inhibited or limited, thereby lowering the efficiency of CBP (Figure 2.9a) (107). Industrial stresses and fermentation processes have close correlations with cell growth and viability, internal secretory pathway mechanisms, secretion levels of proteins and their stability in the medium (111-114). Therefore, the main beneficial characteristics for bioethanol production strains include high tolerance and fermentative capabilities.

Yeast cells have stress-adaptation mechanisms, such as the induction of stress-related proteins (112), changes in membrane composition (lipid composition and membrane fluidity) (115), repression of translation mechanism (kinases that inhibit translation initiation and protein synthesis) (116), accumulation of stress protectants (trehalose, proline, glycogen, sterols and intracellular glycerol) $(117,118)$ and by regulation of gene expression through signal transduction pathways (110-112). During heat-shock and ethanol stress, cells are known to alter plasma membrane properties, by reducing plasma membrane fluidity and increasing the degree of saturation of membrane lipids (119). Stress protectants e.g., proline and trehalose are accumulated in the cell during stressed conditions and have a stress-protective activity, serving multiple functions in vitro such as protein and membrane stabiliser, lowering the $T_{m}$ of DNA, and scavenging of reactive oxygen species (117). 
(a)

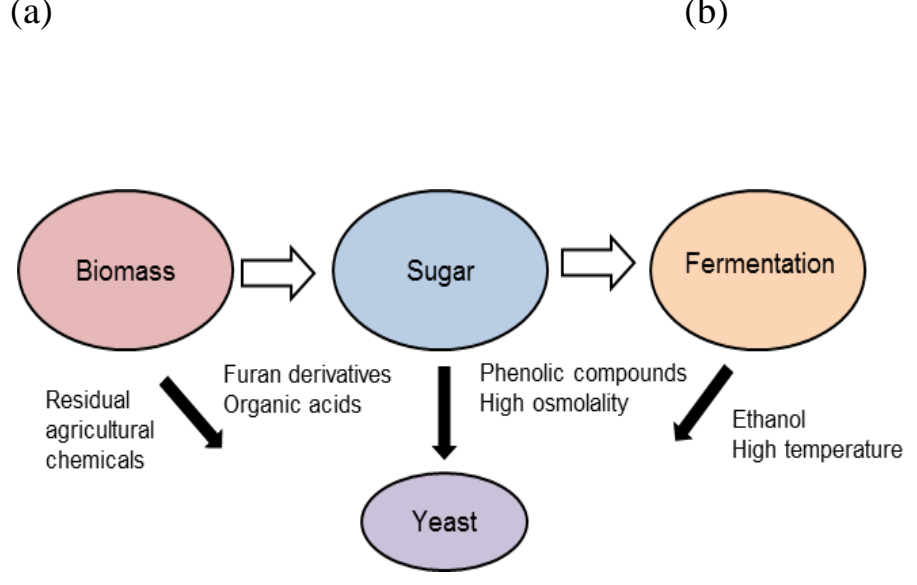

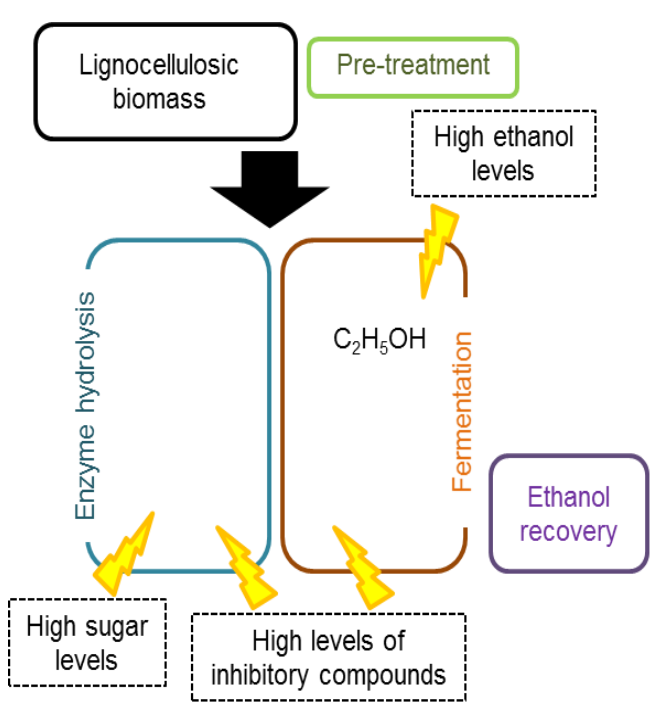

Figure 2.9. Challenges in different steps of bioethanol production process using lignocellulosic materials. (a) Environmental stresses in the bioethanol process that impact yeast. After pre-treatment of biomass, furan derivative, organic acids and phenolic compounds are produced during the release of sugar (51). Inhibitors may prevent fermentation; however both high temperatures and the ethanol produced as an end product are known to inhibit growth (albeit low concentrations of ethanol have been produced to date) (51). (b) Various factors affect different steps of the process and are responsible for the inefficient conversion of biomass at high solids content. Image adapted from Koppram et al. (120).

The most comprehensive data on global genome-wide expression pattern changes in S. cerevisiae following environmental stresses are derived from Gasch et al. (112) and Causton et al. (121). Both research groups suggest a general regulatory programme with genome wide transcriptional changes as a reaction to environmental stresses. It was generally observed by these studies that the common environmental response (ESR or CER) genes are up- or down regulated transiently as a reaction to adjust to a stress, and return to the near normal expression levels after adaptation. Also known as heat shock response (HSR), this ancient and highly conserved transcriptional program results in the immediate synthesis of a battery of cytoprotective genes in the presence of thermal and other environmental stresses. At a genetic level, the general stress response in yeasts is controlled by stress-responsive cis elements (STREs) in the promoter region of a wide range of stress-induced genes $(112,122)$. This had led to the theory that the ESR/CER genes are sensitive to stress conditions that result in a coordinated regulation of transient change for the level expression of about 900 genes $(\sim 14 \%$ of the genes so far predicted to occur in the S. cerevisiae genome). Interestingly, it appears that part of the purpose of the general stress response is to transfer tolerance to the cell so as to withstand future stresses (123). At a phenotypic level, the general stress response can be 
observed upon pre-exposure/pre-adaptation to stress (123), in which exposing the cells to a mild stress condition from a particular stressor gives the cells the ability to survive a severe dose of the same stressor. Hyperosmotic stress is a typical problem in high cell density fermentations because the media require high salt concentrations e.g., batch media have an osmolarity of similar to $0.5 \mathrm{M} \mathrm{NaCl}$ solution (113). During high osmolarity conditions, cells accumulate osmolytes, mainly glycerol, thereby increasing the intracellular osmolarity accordingly (130). The main regulatory stress response to osmotic stress is the HOG (high osmolarity glycerol) pathway and the MAPK (mitogen activated protein kinase) cascade (131). The same genes involved in HSR, namely Msn2p and Msn4p, are induced in osmotic stress, demonstrating ESR is interconnected with osmotic stress (131).

While it is known that a specific inhibitors result in stress-specific responses, it has also been shown that there was a level of overlap between the different stress response pathways, resulting in cross-resistance (125). It has been observed that the heat and ethanol stresses induce essentially identical stress response in yeast, causing misfolding and accumulation of proteins $(112,124)$. The adaptive stress response activates the expression of several heat shock protein (HSPs) that protect the cell by either refolding or degrading the misfolded proteins (125). In eukaryotes, the resident proteins found in the endoplasmic reticulum (ER) are responsible for correct folding (126). These molecular chaperones facilitate protein folding and prevent the accumulation of misfolded protein or aggregate proteins (127). The HSP releases ER stress, suggesting an overlap in the role of (HSR) (often cytosolic) and unfolded protein response (UPR) (an ER response) (128), indicating that the protein-folding process and subsequent secretion is a complex and interdependent process involving many interacting participants (126). It has become clear that metabolic and environmental stresses impact the recombinant protein production (127). Interestingly, there are examples of inducing heat shock response systems which improved secretion yields of recombinant proteins such as $\alpha$-amylase and endogenous invertase secretion in S. cerevisiae, although this was also highly protein-specific (129). The natural S. cerevisiae strains were evaluated for several environmental stresses including high temperature, a range of ethanol concentrations, high $\mathrm{NaCl}$ concentrations (osmolarity), ER- and cell wall stresses as well as inhibitors found in lignocellulosic hydrolysates. 


\subsection{Variation in tolerance capabilities of $S$. cerevisiae strains}

Most microorganisms have shown the ability to adapt to environmental stresses, as a result there is a large degree of phenotypical variation in stress sensitivity and gene expression between different environmental and industrial isolates of $S$. cerevisiae strains, but particularly in vineyard isolates $(109,132-139)$. Interestingly, natural isolates, in particular, have demonstrated innate high tolerance to inhibitory compounds. Comparisons have been made between industrial and laboratory strains in terms of stress tolerance in industrial, lignocellulosic fermentations (138-140) and expression of recombinant genes $(79,96)$. The limitations of laboratory strains are highlighted when compared to industrial S. cerevisiae as done by Pereira et al. (136). The researchers studied peak ethanol levels using biomass hydrolysates and demonstrated that laboratory strains produced 25 -fold less than industrial isolates. The performances of the natural $S$. cerevisiae isolates often outcompeted the domesticated strains for specific traits. Favaro et al. (132), Pereira et al. (136) and Wohlbach et al. (135) all demonstrated the potential of natural isolates of $S$. cerevisiae, which were characterised with robust growth in pre-treated lignocellulosic hydrolysate or tolerance to industrial bioethanol stress conditions. In studies by Ramos et al. (137) and Ruyters et al. (134), natural $S$. cerevisiae isolates were evaluated for ethanol resistance and various stresses for tolerance, as well as evaluating the fermentation yield in stressed fermentation environments, respectively. Ramos et al. (137) observed that most of the natural strains had acquired higher tolerance towards pre-treatment inhibitors, unlike laboratory strain S288c strain. Ruyters et al. (134) found that natural isolates performed better than the industrial strain Ethanol Red in terms of ethanol yield in fermentation experiments mimicking high gravity fermentation and lignocellulosic hydrolysates.

Saccharomyces cerevisiae strains from different genetic backgrounds display a variation in heterologous protein production $(96,141)$, growth rates $(142)$, and ethanol yields $(79,132)$. It is reasonable to assume the same variations exist in the secretion capabilities of key cellulolytic enzymes and abilities to tolerate secretion stress. Therefore, exploring the natural biodiversity of Saccharomyces strains, especially from the ethanol production industry such as wine-making, is was a strategy used in this study to find superior traits for bioethanol strains 


\subsection{Hosts for recombinant DNA technology}

Some of the first biotechnologically produced proteins on the market were made through recombinant DNA, including biopharmaceuticals for example, insulin, interferons, erythropoietin, a vaccine against hepatitis B and industrial enzymes for use in the food, feed, detergents and paper pulp industries $(143,144)$. A suitable host can be selected from a large number of species (Table 2.6) based on its performance regarding parameters such as product yield, productivity, and tolerance to the product or other environmental stresses (e.g., $\mathrm{pH}$, temperature, salt) (145). Escherichia coli was the first host to be used for the production of heterologous proteins due to its high growth rate, cost effective cultivation, high protein production rate and wealth of information available on its genetics, biochemistry and fermentation characteristics (146). However, the limitation of this genus involves the inability of correct protein folding and post-translational processing systems, which leads to heterologous protein build-up in inclusion bodies in the cells, causing proteins to lose their activity and/or structure (147). Therefore, eukaryotic microbial host systems were investigated and evaluated, and found to have a combination of advantages including the ability to perform protein-folding, assembly and post-translational modifications required for a functional protein to be expressed heterologously (143).

As shown in Figure 2.10, around half of the protein based biopharmaceuticals are produced in microbial systems ( $\sim 30 \%$ E. coli and $\sim 20 \%$ S. cerevisiae), with the rest being produced by mammalian cells (148). In a review by Demain et al. (148), it was summarised that more than half of the industrial enzymes are produced by fungi and 30\% in bacteria. Optimisation of such a broad range of hosts is not possible due to limited tools for genetic analysis and engineering, leaving only evolutionary optimisation or random mutagenesis to produce optimised strains (148).

(a)

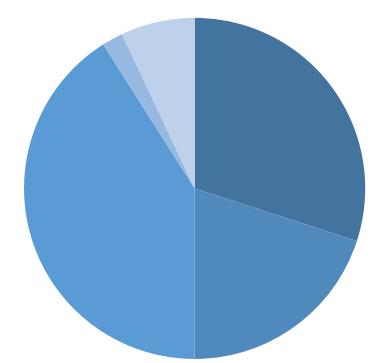

E.coli

- S. cerevisiae

- Mammalian cells

Insect cells

Other systems (b)

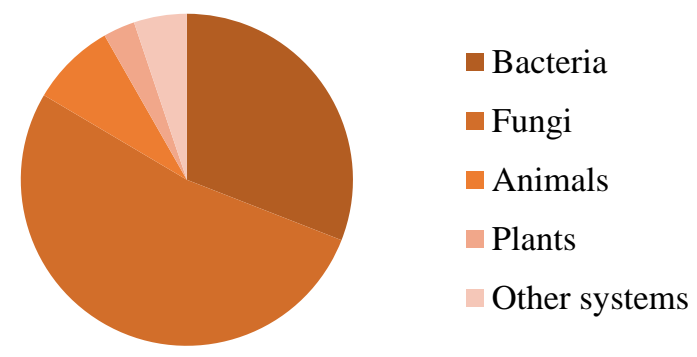

Figure 2.10. Overview of host expression systems producing recombinant proteins including (a) biopharmaceuticals and (b) industrial enzymes as review by Demain et al. (148). 
Table 2.6. Categories and main characteristics of the most important expression systems used for recombinant protein production as summarised in the review by Demain et al. (148).

\begin{tabular}{|c|c|c|c|c|c|c|c|c|}
\hline Category & Organism & Product titer & $\begin{array}{c}\text { Cell } \\
\text { growth }\end{array}$ & $\begin{array}{l}\text { Growth } \\
\text { medium }\end{array}$ & Glycosylation & Folding & Secretion & Advantages \\
\hline Mammalian & BHK & $0.05 \mathrm{mg} / \mathrm{L}$ & \multirow{4}{*}{$\begin{array}{l}\text { Slow } \\
(24 \mathrm{~h})\end{array}$} & \multirow{4}{*}{$\begin{array}{l}\text { Complex } \\
\text { and high } \\
\text { cost }\end{array}$} & Optimal & Optimal & Good & \multirow{4}{*}{$\begin{array}{l}\text { Human-like post translational } \\
\text { modifications (glycosylation, } \\
\text { phosphorylation, acylation), high } \\
\text { productivity, high cell densities at } \\
\text { industrial volumes. }\end{array}$} \\
\hline & $\mathrm{CHO}$ & $3-10 \mathrm{~g} / \mathrm{L}$ & & & Optimal & Optimal & Good & \\
\hline & $\begin{array}{l}\text { NSO-BHK. } \\
\text { HEK }\end{array}$ & $3-5 \mathrm{~g} / \mathrm{L}$ & & & Optimal & Optimal & Good & \\
\hline & PER.C6 & $15-25 \mathrm{~g} / \mathrm{L}$ & & & Optimal & Optimal & Good & \\
\hline \multirow[t]{2}{*}{ Bacterial } & E. coli & $3-15 \mathrm{~g} / \mathrm{L}$ & \multirow[t]{2}{*}{$\begin{array}{l}\text { Rapid } \\
(30 \mathrm{~min})\end{array}$} & \multirow[t]{2}{*}{$\begin{array}{l}\text { Minimum } \\
\text { and low } \\
\text { cost }\end{array}$} & None & $\begin{array}{l}\text { Cytoplasm } \\
\text { (none) } \\
\text { Periplasm } \\
\text { (good) }\end{array}$ & $\begin{array}{l}\text { Media (poor) } \\
\text { Periplasm (good) }\end{array}$ & \multirow{2}{*}{$\begin{array}{l}\text { Fast growth rate, high productivity, } \\
\text { ideal for smaller protein production, } \\
\text { cheap media, well characterised, easy } \\
\text { manipulation. }\end{array}$} \\
\hline & Bacillus spp. & $4-20 \mathrm{~g} / \mathrm{L}$ & & & None & Optimal & Periplasm (good) & \\
\hline \multirow{4}{*}{ Yeast } & Baculovirus & $0.6-11 \mathrm{~g} / \mathrm{L}$ & $\begin{array}{l}\text { Slow } \\
(18-24 \mathrm{~h})\end{array}$ & $\begin{array}{l}\text { Complex } \\
\text { and high } \\
\text { cost }\end{array}$ & Optimal & Optimal & Good & $\begin{array}{l}\text { Easy scale up with high-density } \\
\text { suspension cultures, safety, lack of limit } \\
\text { on protein size, efficient cleavage of } \\
\text { signal peptides, simultaneous } \\
\text { expression of multiple genes. }\end{array}$ \\
\hline & S. cerevisiae & $1.5-9 \mathrm{~g} / \mathrm{L}$ & \multirow{3}{*}{$\begin{array}{l}\text { Rapid } \\
\text { (90 min) }\end{array}$} & \multirow{3}{*}{$\begin{array}{l}\text { Minimum } \\
\text { and low } \\
\text { cost }\end{array}$} & Optimal & Optimal & Optimal & \multirow{3}{*}{$\begin{array}{l}\text { Superior long-term genetic stability, } \\
\text { ideal for larger protein (larger } 50 \mathrm{kD} \text { ) } \\
\text { production, post translational } \\
\text { modifications, ideal for enzyme } \\
\text { production on a large scale. }\end{array}$} \\
\hline & P. pastoris & $1.5-14 \mathrm{~g} / \mathrm{L}$ & & & Optimal & Optimal & Optimal & \\
\hline & H. polymorpha & $1.4-13.5 \mathrm{~g} / \mathrm{L}$ & & & Optimal & Optimal & Optimal & \\
\hline \multirow{2}{*}{$\begin{array}{l}\text { Filamentous } \\
\text { fungi } \\
\text { (moulds) }\end{array}$} & $\begin{array}{l}\text { A niger, } \\
\text { Fusarium spp. }\end{array}$ & $1-25 \mathrm{~g} / \mathrm{L}$ & \multirow{2}{*}{$\begin{array}{l}\text { Rapid } \\
(90 \mathrm{~min})\end{array}$} & \multirow{2}{*}{$\begin{array}{l}\text { Minimum } \\
\text { and low } \\
\text { cost }\end{array}$} & Optimal & Optimal & Optimal & \multirow{2}{*}{$\begin{array}{l}\text { Secret high levels of bioactive proteins, } \\
\text { post-translational modifications, } \\
\text { superior long-term genetic stability. }\end{array}$} \\
\hline & $\begin{array}{l}\text { Trichoderma } \\
\text { spp. }\end{array}$ & $1-35 \mathrm{~g} / \mathrm{L}$ & & & & Optimal & Optimal & \\
\hline $\begin{array}{l}\text { Transgenic } \\
\text { animal }\end{array}$ & $\begin{array}{l}\text { Cows, sheep, } \\
\text { goats }\end{array}$ & $10-40 \mathrm{~g} / \mathrm{L}$ & N/A & N/A & Optimal & Optimal & $\begin{array}{l}\text { Mainly produced } \\
\text { in milk and urine, } \\
\text { also egg white, } \\
\text { blood and seminal } \\
\text { plasma }\end{array}$ & $\begin{array}{l}\text { Large quantities of proteins produced, } \\
\text { easy to scale production up or down to } \\
\text { meet demand, glycosylation, easy } \\
\text { harvesting. }\end{array}$ \\
\hline
\end{tabular}


In order to lower costs of the production of cellulolytic enzymes needed for hydrolysis of the biomass, the biological steps of enzyme hydrolysis and fermentation can be performed simultaneously by a single microbe through the process of CBP (2). As a result, fermenting organisms need to be able to efficiently express cellulases and ferment sugars into a single product at high titers (46). As of yet, no natural microorganism exhibits all the features desired for CBP, however a number of microorganisms, both bacteria and fungi, possess some of the desired properties as reviewed by Fischer et al. (25). Some of the candidates considered as potential recombinant cellulolytic microorganisms into which saccharolytic systems have been engineered include E. coli, A. niger, H. polymorpha, P. pastoris, Bacillus spp., Corynebacterium spp., Glutamicum spp., lactic acid bacteria and S. cerevisiae (as reviewed in Table 2.6) (1). Since there is no clear path to creating the optimal host, most researchers combine desirable features of different microbes into an engineered strain using recombinant DNA technology (2). Recent progress in the development of microorganisms through evolutionary, metabolic, and synthetic engineering approaches have paved the way for using organisms that natively produce the compound of interest, to be endowed with heterologous cellulose hydrolysis (1). This strategy started with well-known species, such as $S$. cerevisiae and E. coli, and optimises it for the desired product and required bio-processing conditions (148). Saccharomyces cerevisiae is one of the widely studied and used yeasts in both laboratory and industrial levels due to certain advantages it has over bacteria as a cloning host, including rapidly growing in simple media, reaching high cell densities, robust, high ethanol titers, secreting heterologous proteins into extracellular broth and having the most advanced genetic research database than any other eukaryote (82).

\subsubsection{Saccharomyces cerevisiae as CBP hosts}

Evidence for the production of fermented beverages by Saccharomyces yeasts, mainly S. cerevisiae, dates at least as far back as 7000 B.C., with the earliest found in China (149), then Iran, and, slightly later, Egypt (150). Further specialising and selection of yeasts resulted in development of different types of alcoholic beverages by natural selection for growth on differing substrates (grapes vs. grain) (151). As a result of this long history of domestication, there now exists different strains of $S$. cerevisiae that have been collected from differing industrial and wild habitats (152). Being one of the organisms furthest along in research and development stage, S. cerevisiae has high ethanol yields and productivity, high growth rates,

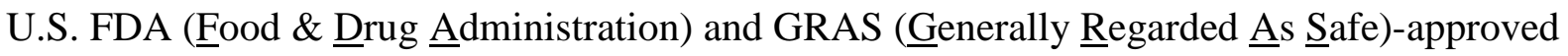
status and a general robustness to environmental stresses encountered during industrial 
fermentations (95). This species can generate ethanol as its main fermentation product and is superior to bacteria, other yeasts and filamentous fungi due to various physiological characteristics regarding ethanol production in context (149). Being a strong fermenting strain, S. cerevisiae can produce up to $200 \mathrm{~g} / \mathrm{L}$ ethanol in classical industrial fermentations (8). Other robust $S$. cerevisiae strains, including industrial strain Ethanol Red, have been reported to produce up to $250 \mathrm{~g} / \mathrm{L}$ ethanol and are being used for expression of recombinant genes for bioethanol production (153). However, in order for $2 \mathrm{G}$ cellulosic ethanol distillation to be economically feasible, ethanol titer needs to reach $40 \mathrm{~g} / \mathrm{L}$ within a $96 \mathrm{~h}$ period with as low enzyme loading as possible $(154,155)$. One of the reasons for the high cost is the high steam energy consumption in the distillation of fermentation broth with low ethanol titer when lignocellulose materials are used as feedstock $(156,157)$. Nevertheless, economic ethanol can be produced from lignocellulosic substrates using S. cerevisiae (157). For example, currently $0.21 \mathrm{~g}$ ethanol/ $1 \mathrm{~g}$ dry cellulosic feedstock is being produced with available technologies and can be increased to at least $0.27 \mathrm{~g}$ ethanol/ $\mathrm{g}$ biomass using simpler processes (158).

The ideal CBP host needs to tolerate varying concentrations of the end product at high temperatures and extreme $\mathrm{pH}$ (to avoid cooling and sterilization costs) (159). During the fermentation process, a series of compounds influence the optimum $\mathrm{pH}$ for yeast development in such a way that the yeast Saccharomyces species often becomes dominant (160). Furthermore, its ability to grow in both anaerobic and aerobic environments, and high glycolytic flux enables it to thrive in all stages of the fermentation process whilst competing with other microbes (3). This yeast is fast growing, therefore managing to inhibit the growth of other non-Saccharomyces yeast strains (62). Another important feature associated with any large scale industrial process is the high cost of maintaining sterile conditions and the high risk of contamination (20). The use of antibiotics is undesirable due to economic feasibility and because resistance to antibiotics may develop (20). Up to now, high temperatures and low pHs have been an effective measure in this regard, but this strategy requires highly tolerant hosts. Fortunately, S. cerevisiae is a generally robust yeast and can perform well under challenging culturing conditions (including pre-treated lignocellulosic biomass) $(161,162)$.

Finding or constructing an optimal CBP host is a necessary prerequisite of any metabolic engineering effort (159). In this context, the ideal host for CBP would hydrolyse lignocellulose, hemicellulose and cellulose and utilise all available sugars to produce ethanol, or a similar valuable product, at high rates and titers (159). Hexose sugars such as glucose, mannose, and 
galactose can be readily fermented to ethanol by most yeast species, however, only a small number of yeast species that can naturally metabolise xylose or arabinose have been identified (163). Examples of xylose and arabinose - utilising species include Candida spp. and isolates of Pichia spp. and several genes required for uptake and metabolism have been characterised in these strains (163). Despite their potential for diverse sugar metabolism, these species have not advanced for development as cell factories for bioethanol production because of low ethanol yields (163). Although natural isolates of $S$. cerevisiae have been identified to grow slowly on medium containing sole carbon source of xylose (164), in general, xylose metabolism in this yeast is inefficient and unsuitable for industrial processes and are likely a fail-safe mechanism for survival in nutrient-deprived conditions.

Saccharomyces cerevisiae demonstrates characteristics for an ideal host including genetic malleability, high transformation efficiency, well characterised metabolic engineering tools, availability of "omics" platforms and knowledge on the physiology of the strain (25). Genetic engineering requires the alteration of phenotypes dictated by multiple genes (25), and thus a systematic approach is required of which a prerequisite is substantial knowledge of the host. For this reason laboratory strains are used since they are "research-friendly", however may not necessarily be robust enough for industrial processes (2). As a heterologous host, S. cerevisiae can produce up to $1 \mathrm{~g} / \mathrm{L}$ of recombinant protein levels (68), however this pales in comparison to the cellulase secretion observed in natural cellulolytic species. For example, hypersecretor T. reesei mutant RUT-C30 is known to secrete between 20-100 g/L cellulase enzymes (23). Recently, it has been observed that significantly higher recombinant protein levels and enzyme activities can be obtained by expressing cellulases in polyploid yeasts Saccharomyces pastorianus (97). However, this increased activity in S. pastorianus was suggested to be due to increased protein stability due to its tetraploid status (97).

\subsubsection{Expression of cellulase genes}

Milestone studies have demonstrated significant progress towards the development of CBP strains by engineering cellulolytic systems into fermenting strains. As early as the 1990s, cellulolytic enzymes were expressed in bacteria $(165,166)$ and yeast $(167)$ as a way of reducing the cost of cellulase production. Attempts at expressing recombinant cellulase genes in yeasts are plentiful due to the traditional role of the brewer's yeast S. cerevisiae in bioethanol production. Research has been performed in S. cerevisiae regarding single or multiple 
production of the three main classes of cellulases required for the hydrolysis of crystalline cellulose, namely EGs, CBHs and BGLs $(6,168)$ and will be discussed briefly in this section.

Myung et al. (169) first reported ethanol production from media containing cellulose by expressing several endo/exo-glucanases and BGLs in S. cerevisiae. Using delta integration and high-copy plasmids, multiple copies of a bifunctional endo/exo-glucanase and BGL were inserted into laboratory $S$. cerevisiae strains, resulting in growth on cello-oligosaccharides. Furthermore, less enzymes were needed to be externally added when applied in SSF. However, the cellulase enzyme levels and ethanol production levels were low, and did not allow for growth on cellulose as a sole carbon source. It was suggested that cell growth and ethanol production are controlled by glucose concentration in culture broth and during an initial stage of cultivation carbon flux was directed to ethanol production due to the fact that the glucose concentration contained cellodextrins high enough to convert it to ethanol. During glucose starvation, the cellulolytic enzyme titers of transformants did not reach the amount needed to convert the carbon flux from cellodextrins to ethanol. Therefore, higher enzyme activity levels are needed to produce more ethanol from cellulose.

Recently, studies have shown that co-expression of cellulases tethered to the cell wall (170), as free enzymes (171) or as part of a mini- cellulosomes (172) have been effective in allowing conversion of amorphous cellulose to ethanol. Early studies by Den Haan and co-workers (102) demonstrated ethanol production directly from amorphous cellulose by co-expressing T. reesei EG (cel7B) and S. fibuligera BGL (cel3A) genes in a laboratory strain of S. cerevisiae. The recombinant strains were able to grow on and hydrolyse YP-phosphoric acid swollen cellulose (PASC), producing modest amounts of ethanol after fermentation $(1.0 \mathrm{~g} / \mathrm{L}$ in $192 \mathrm{~h})$. Following these landmark studies, other groups demonstrated the expression of cellulase genes in S. cerevisiae and their use for fermentation of lignocellulose to ethanol.

Recent advances in the field have shown that expression of S.f.cel3A, T.r.cel5A and T.e.cel7A genes have been expressed in S. cerevisiae resulting in concomitant ethanol production from cellulose $(6,68,173)$, however this does not hold true for all studies, in some cases no growth on cellulose or low enzyme activity levels were observed $(167,174,175)$. Assessing the impact of advances reported by Ilmén et al. (68), further data is needed under anaerobic conditions and industrial conditions. In this study, we investigate BGL (S.f.Cel3A) activity levels under oxygen-limited conditions (Section 3.3.6), as well as assessed the growth of transformants expressing cellulase genes on cellulose substrate (Section 3.3.7). 
Two different cellulase systems, referred to as complexed and non-complexed have been described. Complexed cellulase systems are multi-enzyme complexes, referred to as cellulosomes, which remain tethered to the cell wall of cellulolytic bacteria (3). Cell wall tethering leads to an effective increase in concentration of cellulolytic enzymes (97). On the other hand, expressing cellulolytic enzymes so that the proteins are untethered facilitates the binding of enzymes at multiple sites along the length of the cellulose chain (10). As described previously, another way key enzymes are produced for CBP include being tethered separately to cell walls or tethered to the cell wall in a mini-cellulosome $(170,176,177)$. Yanase and co-workers (10), demonstrated cellulose degradation to ethanol in YP-PASC medium when the T. reesei endoglucanase (T.r.cel5A) and cellobiohydriolase II (cel6A), and S. fibuligera cel3A genes were integrated into genomes of $S$. cerevisiae, with the S.f.Cel3A anchored to the cell surface, while the Cel5A and Cel6A were either anchored or secreted. More progress was seen by Jeon and co-workers (178) with the expression of Clostridium thermocellulm endoglucanase (celD) and S. fibuligera $\beta$-glucosidase (cel3A) genes in $S$. cerevisiae resulting in ethanol production from different media that did not need peptone or yeast extract e.g., carboxymethyl cellulose (CMC) (8.56 g/L), $\beta$-D-glucan $(9.67 \mathrm{~g} / \mathrm{L})$ after $16 \mathrm{~h}$ and PASC $(7.16 \mathrm{~g} / \mathrm{L})$ after $36 \mathrm{~h}$ after pre-culturing in synthetic galactose medium and washing in minimal media.

To date, the co-expression of all crucial enzymes, as well as the necessary enzyme dosage for efficient cellulose conversion produced by engineered yeasts has not yet been achieved, mainly due to the metabolic burden related to heterologous enzyme synthesis and growth on cellulose (179). Although, the use of such a microorganism would be ideal, another proposed solution is a consortium of CBP microbes in an appropriate ratio for the expression of complementary enzymes instead of co-expressing all the enzymes in a single yeast (180). Therefore, ideal CBP-microbes would effectively secrete high titers of a single cellulolytic enzyme, thereby significantly reducing the titers of externally added enzymes. Similar to Wei et al. (181) and Ilmén et al. (68), co-culture fermentations where performed in this study, allowing rational volume mixing of transformant cultures in accordance with the optimal ratio of cellulases required for efficient degradation of cellulosic substrates. In this study, we use co-culture fermentations on Avicel cellulose (Section 3.3.7). 


\subsubsection{Protein secretion capacity and secretion stress}

In order for CBP to effectively produce $2 \mathrm{G}$ cellulosic bioethanol, the host microbe should be able to efficiently secrete high titers of a large set of heterologous enzymes in order to completely hydrolyse cellulose into fermentable sugars (3). The inability of $S$. cerevisiae to degrade lignocellulose is not only due to the lack of relevant enzymes but is also related to the low efficiency of expression and secretion of cellulolytic enzymes $(182,183)$. Therefore, the essential value of cellulase gene expression has shifted the focus of studies towards optimising the titers of protein and enzyme activity secreted by S. cerevisiae (183-187). The production of heterologous proteins by fungal species is usually much less efficient than the production of native proteins and several steps in the secretory pathway (e.g., translation, translocation, folding, transport and secretion) are potential bottlenecks for recombinant protein production (187). It has been theorised that protein secretion is often hampered during the quality control steps of protein folding and membrane crossing events, contributing to the noted observation that the yeast secretory systems is 100 - to 1000 -fold lower than the theoretical protein yields potential $(111,186-188)$.

In order for proteins to be secreted in their active form, they pass through a secretory pathway where they are folded and modified (186). Environmental and physiological demands e.g., cell differentiation, $\mathrm{pH}$ and temperature, nutrient limitation and expression of proteins, etc. can lead to an imbalance of protein folding load and the protein folding capacity in the endoplasmic reticulum (ER), resulting in an accumulation of misfolded proteins i.e. ER stress (169). Several quality control systems have evolved to ensure properly folded proteins move through the secretory pathway (186), including unfolded protein response (UPR) which activates the gene expression programme that restores homeostasis by enhancing ER protein folding capacity and protein degradation response known as the ER-associated degradation (ERAD), reducing translation and entry of new proteins into the ER as reviewed by Gasch et al. (112). In this study we characterised the protein secretory pathway components and the regulatory range of the secretion stress response in the natural strains by inducing ER stress through chemical secretion 'blockers' such as folding inhibitor dithiothreitol (DTT), the glycosylation inhibitor tunicamycin, translation inhibitor hygromycin B and secretion stressor sodium orthovanadate which is known to prevent the release of secretion vesicles (123, 189-191) (Section 3.3.7).

Other factors that can affect secretion yields include the size and charge of the protein, codon usage and optimization, culturing conditions, glycosylation, variation of secretion signals, 
vector systems (type of promoters, codon usage and leader sequences) as reviewed by Idiris et al. (186). Strides have been made towards enhancing secretion capacity of $S$. cerevisiae (as reviewed in Table 2.7). There are several strategies to increase protein production in yeasts including classical mutagenesis, increasing copy numbers of recombinant genes and limiting the degradation of the product by proteases (may be controlled by the use of defective mutants or by changing the sequence of the protein) (192), while other studies have shown that the natural ability of certain strains to produce secreted proteins may differ significantly (68).

The secretion capacity of a strain depends on various genetic and physiological characteristics of the host strain (186) including glycosylation levels. Unpredictable co- and post-translation events can cause alterations in structure and functions of the secreted proteins, which in turn affect secretion titers (200). Studies have revealed that properties such as hyperglycosylation and heterologous, protein stress are important determinants of secretion capabilities $(68,187$, 201). Since almost all secreted proteins are $O$ - or $N$-glycosylated, alterations to these pathways are likely to affect protein production and secretion or change the glycosylation pattern of the secreted proteins, altering their stability and biological activity (202). The cellular limitations of protein overexpression in yeasts include gene dosages and induction (183), mRNA stability (203), translational capacity (rRNA) (204), protein folding (205), proteolytic degradation (206), growth rates and phase (212). Protein quality, stability, yield and productivity are also important parameters that need to be addressed in order to allow sufficiently low cost to allow marketing (207). A high yield of protein is also dependent on the stability of corresponding mRNA e.g., a Bl21 strain has been created with a rne131 mutation which confers high stability of mRNA and ultimately increased gene expression (146). Recombinant protein secretion is also highly protein-specific (182) and unknown factors may be involved as genes with highly similar sequences have been shown to yield vastly different results as seen by Ilmén et al. (68). 
Table 2.7. Secretion enhancing strategies in S. cerevisiae strains.

\begin{tabular}{|c|c|c|}
\hline Secretion enhancing strategies & Description & Ref. \\
\hline Optimising protein folding pathways & $\begin{array}{l}\text { Over-expressing protein folding aids like chaperones and manipulating } \\
\text { regulators of the UPR pathway. }\end{array}$ & $(193)$ \\
\hline Optimising culturing conditions & $\begin{array}{l}\text { Designing an efficient medium for producing heterologous proteins. } \\
\text { Manipulating proteolytic degradation which is dependent on the nitrogen } \\
\text { composition of medium. }\end{array}$ & $\begin{array}{l}(194) \\
(195)\end{array}$ \\
\hline Minimise protease activity & $\begin{array}{l}\text { Protease activity can be minimised by using protease inhibitors or gene } \\
\text { deletions to form protease deficient strains. Buffering the media could greatly } \\
\text { reduce proteolytic degradation because some proteases are inhibited at a lower } \\
\mathrm{pH} \text {. }\end{array}$ & $\begin{array}{l}(186) \\
(195)\end{array}$ \\
\hline Selecting suitable hosts & Select hosts based on host-protein compatibility. & (196) \\
\hline Optimising fermentation conditions & Low $\mathrm{pH}$ and rich media resulted in higher cellulase gene expression levels. & $(197)$ \\
\hline Optimising codon and promoters & $\begin{array}{l}\text { Codon usage played role in production of large quantities of heterologous } \\
\text { proteins. Select optimal promoters for enhanced secretion levels. }\end{array}$ & $(198)$ \\
\hline Increasing gene copy number & $\begin{array}{l}\text { Multi-copy expression plasmid generally yielded higher levels of recombinant } \\
\text { proteins. }\end{array}$ & $(199)$ \\
\hline
\end{tabular}




\subsection{Diversity of Saccharomyces cerevisiae: Industrial and laboratory strains}

Different studies on the population genomics on $S$. cerevisiae e.g., from industrial fermentations to vineyards (208-215), have generated a large amount of information that help to explain genetic variability within the species and also the evolutionary processes that have led to the adaptation of particular strains to specific environments $(216,217)$. For the purposes of this thesis, however, diversity of $S$. cerevisiae strains will be classified into three main groups: laboratory, industrial and natural strains. The purpose of such a classification relies on physiological, phenotypic and genetic differences between these groups that are of importance when evaluating relevant industrial phenotypes.

Industrial S. cerevisiae strains are usually polyploidy and/or aneuploid strains that are classified according to the production purpose (218). These strains have developed and adapted over long periods of time to a specific industrial environment e.g., bread, wine, beer, sake, ad bioethanol yeast (219). In general, $2 \mathrm{G}$ cellulosic ethanol fermentation conditions are harsh, especially with additional challenges of difficult substrates such as lignocellulosic biomasses, and require the use of so-called industrial strains. Regarding industrial strains for ethanol production, especially looking at the Brazilian bioethanol industrial (based on diluted sugar cane juice and molasses), the strains used are selected for their ability to keep high fermentative capacity and viability under specific environmental stressors such as low $\mathrm{pH}$, poor nutrient availability, high ethanol concentration, fluctuating osmolality, high sugar concentrations and fluctuating temperatures (218-220). The MH1000 strain (industrial distillery yeast, Stellenbosch University, South Africa) is a prime example of a commercial strain that has a proven track record of excellent fermentation capacity and yield, high robustness to dehydration and stress tolerance during industrial conditions and transport (221). Therefore, MH1000 is used as a reference strain in the context of this study.

In stark contrast to industrial strains, academic or laboratory strains are defined as a set of reference strains, with a defined ploidy (often haploid), defined mating type and easily manipulated using modern molecular techniques for experimental procedures and are used in physiological, genetic, and biochemical engineering research (218). Some of the most commonly used laboratory strains include S288c and Y294, which have been used as reference strains for the yeast genome sequencing project (139) and are also used as reference strains in this study (139). The laboratory strains are characterised by - and have been selected for - high sporulation efficiency, spore viability and mating efficiency, high transformation efficiency, 
heterothallic behaviour, and the availability of auxotrophic markers and isogenic strains (222, 223). This makes laboratory strains very attractive for manipulations, however, laboratory strain are also characterised by having a generally inferior robustness and reduced fermentation capacity under non-optimal conditions $(218,224)$. This can be seen in S288c, a S. cerevisiae laboratory strain, which was unable to grow in low $\mathrm{pH}$ and high osmolality, and therefore, cannot be used in high ethanol producing industries $(222,223)$.

So far, most of the research regarding surmounting the challenges imposed by lignocellulosic substrate for ethanol has been carried out in domestic yeast strains, with the research mainly being carried out under standard laboratory conditions (e.g., rich, mineral medium and well-controlled environmental conditions). However, the development of efficient industrial processes requires the transfer of all relevant genetic modification of the more robust background of industrial strains and to assess the changes under processes conditions. However, in the past, genetic manipulations on industrial strains were feasible, but burdensome (218). In this context, it is worth noticing that the tools to genetically manipulate industrial strains have expanded exponentially and previous limitations associated with the lack of markers or restriction of the use of antibiotics have been overcome.

\subsubsection{Exploitation of natural diversity for industry}

Ethanol plants in Brazil traditionally use baker's yeast as starter cultures, due to its low cost and availability in amounts required (18). However, many starter strains were unable to survive the stressful condition imposed by the industrial fermentation process including high ethanol concentrations, high temperature and osmotic stress due to sugars and salts, acidity, sulphite and bacterial contamination. A study by da Silva-Filho et al. (228) performed karyotyping analyses/PCR-fingerprinting of yeast samples from five different distilleries and two other industrial $S$. cerevisiae strains, finding that these strains could not outcompete the indigenous yeasts that often contaminated the industrial process, suggesting that indigenous strains could be more adapted to the industrial process than commercial strains. Additionally, the yeast used in the plants generally do not survive more than 30 days in industrial processes for ethanol production due to the stressful conditions imposed by industrial fermentation (228). This confirms the results shown by Basso et al. (160) that observed that only a natural strain previously isolated from a distillery could survive the recycling process, and in most distilleries the natural strains of Saccharomyces were dominant and persisted in the fermenters. As a result, 
new natural strain were isolated, characterised and proposed to be used as a starter culture for $1 \mathrm{G}$ bioethanol production.

Interactions between an organism and its environment can significantly influence phenotypic evolution, therefore, natural yeast isolates from diverse environments also have widely varying phenotypes under various conditions, and many of these phenotypes may be related to variation in gene expression (225). Several attempts have been made to select suitable industrial strains of $S$. cerevisiae for CBP $(109,153,218,224,226)$, however, the scope documented by these studies were either limited to the tolerance or fermentation abilities of these strains. For example, these studies have mainly focused on certain characteristics, like ethanol yields, growth rates and resistances $(133,137,225,227)$, with natural strains receiving special attention because of their suggested competitiveness and stress tolerance during industrial fermentation $(109,135)$. The same variations would be expected for their protein secretion capacity and their ability to tolerate ER and secretion stress.

A research paper by Gurgu et al. (79) took advantage of natural diversity $S$. cerevisiae strains to identify host strains for increased secretion ability of heterologous enzymes. By comparing the heterologous S.f.Cel3A expression levels and ethanol yields in eleven industrial strains of S. cerevisiae, a positive correlation between enzyme expression and cellobiose fermentation efficiency was described. The genetic background of host strains is an important parameter governing heterologous protein production, as observed by the work of De Baetselier et al. (96) on $S$. cerevisiae. After screening several recombinant $S$. cerevisiae strains producing A. niger glucose oxidase, a 100-fold difference was found between the lower and higher performances. The fermentation processes produced up to $3 \mathrm{~g} / \mathrm{L}$ of active enzyme using an ADH2-GPD hybrid promoter. Thus, despite its crucial importance, the impact of the genetic background is often neglected, probably due to the difficulties of such a study. It is thus reasonable to speculate that a diverse range of secretion phenotypes would be observed using different natural yeast isolates.

In the following section, we sought to address the shortcomings of low enzyme titers by assessing the secretion phenotypes that exists in S. cerevisiae strains, from a culture collection of environmentally-isolated $S$. cerevisiae strains, by comparing them to known industrial and laboratory strains. To our knowledge, no study has evaluated different cellulase genes expressed in natural $S$. cerevisiae strains, demonstrating variation in secreted cellulase activity. Nevertheless, such information might be crucial for selection of new, multi-tolerant strains that 
could serve as efficient bioethanol production strains or as good candidates for identifying desirable phenotypic traits that could be transferred to industrial strains through genetic engineering or breeding.

\subsection{This study}

This study was undertaken in the light of pressing need to find alternative renewable fuel resource. Cellulosic bioethanol technology is becoming important, especially in developing countries, because this technology is inclusive, innovative, socially acceptable, financially viable, and balanced with adequate and sustainable food production (5). Finding an optimal strain for CBP, a microbe that can express high titers of cellulolytic enzymes to hydrolyse biomasses and simultaneously produce ethanol at a high titer in the presence of environmental stresses, would significantly reduce the costs associated with the conversion process (3). Cellulolytic enzyme secretion studies have been solely focused on heterologous expression in domesticated strains of $S$. cerevisiae $(109,219)$ with no studies to our knowledge focusing on the comparative analysis of enzyme expression patterns among natural yeast strains. In this study, a comprehensive secretion evaluation of a large collection of natural $S$. cerevisiae strains was performed. Thirty strains were evaluated based on their capabilities to heterologously produce and secrete different cellulolytic activities (Section 3.3.1-3.3.2). Natural strains identified to have desirable phenotypes were further characterised (Section 3.3.3-3.3.4) and evaluated for industrially relevant characteristics including ploidy state (Section 3.3.4), growth vigour (Section 3.3.5), fermentation profiles (Section 3.3.6-3.3.7) and stress sensitivity to environmental factors (Section 3.3.8). This study accentuates the value of natural $S$. cerevisiae strains to serve as potentially robust and highly productive "chassis" organisms for future biofuel strain development.

\subsection{References}

1. Hasunuma T, Okazaki F, Okai N, Hara KY, Ishii J, Kondo A. 2013. A review of enzymes and microbes for lignocellulosic biorefinery and the possibility of their application to consolidated bioprocessing technology. Bioresour. Technol. 135:513-22.

2. Wilson DB. 2009. Cellulases and biofuels. Curr. Opin. Biotechnol. 20:295-9.

3. Lynd LR, Van Zyl WH, McBride JE, Laser M. 2005. Consolidated bioprocessing of cellulosic biomass: An update. Curr. Opin. Biotechnol. 16:577-583.

4. Yamada R, Hasunuma T, Kondo A. 2013. Endowing non-cellulolytic microorganisms with cellulolytic activity aiming for consolidated bioprocessing. Biotechnol. Adv. 31:754-63. 
5. Walwyn DR, Brent AC. 2015. Renewable energy gathers steam in South Africa. Renew. Sustain. Energy Rev. 41:390-401.

6. Van Zyl W.H, Lynd L.R., Den Haan R. and McBride J.E., 2007. Consolidated bioprocessing for bioethanol production using Saccharomyces cerevisiae. In Biofuels (pp. 205-235). Springer Berlin Heidelberg.

7. Fujita Y, Ito J, Ueda M, Fukuda H, Kondo A. 2004. Synergistic Saccharification, and Direct Fermentation to Ethanol , of Amorphous Cellulose by Use of an Engineered Yeast Strain Codisplaying Three Types of Cellulolytic Enzyme 70:1207-1212.

8. Lin Y, Tanaka S. 2006. Ethanol fermentation from biomass resources: current state and prospects. Appl. Microbiol. Biotechnol. 69:627-42.

9. Blanchard R, Richardson DM, O'Farrell PJ, Von Maltitz GP. 2011. Biofuels and biodiversity in South Africa. S. Afr. J. Sci. 107:1-8.

10. Yanase S, Yamada R, Kaneko S, Noda H, Hasunuma T, Tanaka T, Ogino C, Fukuda H, Kondo A. 2010. Ethanol production from cellulosic materials using cellulase-expressing yeast. Biotechnol. J. 5:449-55.

11. Weber C, Farwick A, Benisch F, Brat D, Dietz H, Subtil T, Boles E. 2010. Trends and challenges in the microbial production of lignocellulosic bioalcohol fuels. Appl. Microbiol. Biotechnol. 87:1303-15.

12. Naik SN, Goud V V, Rout PK, Dalai AK. 2010. Production of first and second generation biofuels: A comprehensive review. Renew. Sustain. Energy Rev. 14:578-597.

13. Ma F, Hanna MA. 1999. Biodiesel production : a review . Bioresource tech.1 70:1-15.

14. Bart JCJ, Palmeri N, Cavallaro S. 2010. Biodiesel science and technology: from soil to oil. Elsevier.

15. Christophe G, Kumar V, Nouaille R, Gaudet G, Fontanille P, Pandey A, Soccol CR, Larroche C. 2012. Recent developments in microbial oils production: a possible alternative to vegetable oils for biodiesel without competition with human food? Brazilian Arch. Biol. Technol. 55:29-46.

16. Weiland P. 2010. Biogas production: current state and perspectives. Appl. Microbiol. Biotechnol. 85:849-60.

17. Montgomery LFR. 2014. Pretreatment of feedstock for enhanced biogas production.IEA Bioenergy. Ireland.

18. DeAngelis KM, Allgaier M, Chavarria Y, Fortney JL, Hugenholtz P, Simmons B, Sublette K, Silver WL, Hazen TC. 2011. Characterization of trapped lignin-degrading microbes in tropical forest soil. PLoS One 6:e19306-e19306.

19. Waldron KW. 2010. Bioalcohol production: biochemical conversion of lignocellulosic biomass. Elsevier.

20. Menon V, Rao M. 2012. Trends in bioconversion of lignocellulose: Biofuels, platform chemicals \& biorefinery concept. Prog. Energy Combust. Sci. 38:522-550. 
21. Wang G, Li W, Li B, Chen H. 2008. TG study on pyrolysis of biomass and its three components under syngas. Fuel 87:552-558.

22. Kim S, Dale BE. 2004. Global potential bioethanol production from wasted crops and crop residues. Biomass and Bioenergy 26:361-375.

23. Lambertz C, Garvey M, Klinger J, Heesel D, Klose H, Fischer R, Commandeur U. 2014. Challenges and advances in the heterologous expression of cellulolytic enzymes: a review. Biotechnol. Biofuels 7:135.

24. Baskar C, Baskar S, Dhillon RS. 2012. Biomass Conversion: The Interface of Biotechnology, Chemistry and Materials Science. Springer Science \& Business Media.

25. Fischer CR, Klein-Marcuschamer D, Stephanopoulos G. 2008. Selection and optimization of microbial hosts for biofuels production. Metab. Eng. 10:295-304.

26. Wang M, Saricks C, Santini D. 1999. Effects of fuel ethanol use on fuel-cycle energy and greenhouse gas emissions.

27. Hamelinck CN, Van Hooijdonk G, Faaij APC. 2005. Ethanol from lignocellulosic biomass: techno-economic performance in short-, middle-and long-term. Biomass and bioenergy 28:384410.

28. Al-Baghdadi MAS. 2003. Hydrogen-ethanol blending as an alternative fuel of spark ignition engines. Renew. Energy 28:1471-1478.

29. He B-Q, Hao J-M, Yan X-G, Xiao J-H. 2003. A study on emission characteristics of an EFI engine with ethanol blended gasoline fuels. Atmos. Environ. 37:949-957.

30. Zaldivar J, Nielsen J, Olsson L. 2001. Fuel ethanol production from lignocellulose: a challenge for metabolic engineering and process integration. Appl. Microbiol. Biotechnol. 56:17-34.

31. Petersen A. M, Melamu R, Knoetze JH, Görgens JF. 2015. Comparison of second-generation processes for the conversion of sugarcane bagasse to liquid biofuels in terms of energy efficiency, pinch point analysis and Life Cycle Analysis. Energy Convers. Manag. 91:292-301.

32. Tomás-Pejó E, Oliva JM, Ballesteros M, Olsson L. 2008. Comparison of SHF and SSF processes from steam-exploded wheat straw for ethanol production by xylose-fermenting and robust glucose-fermenting Saccharomyces cerevisiae strains. Biotechnol. Bioeng. 100:11221131.

33. Cavka A, Alriksson B, Rose SH, van Zyl WH, Jönsson LJ. 2014. Production of cellulosic ethanol and enzyme from waste fiber sludge using SSF, recycling of hydrolytic enzymes and yeast, and recombinant cellulase-producing Aspergillus niger. J. Ind. Microbiol. Biotechnol. 41:1191-200.

34. Tabatabaei M, Karimi K, Kumar R, Horváth IS. 2015. Renewable Energy and Alternative Fuel Technologies. Biomed Res. Int.

35. Saha BC, Cotta MA. 2012. Ethanol production from lignocellulosic biomass by recombinant Escherichia coli strain FBR5. Landes Bioscience.197-202.

36. Maria A, Galletti R, Antonetti C. 2011. Lignocellulosic biomass. Bioresources 7:1824-1835. 
37. Ratanakhanokchai K, Waeonukul R, Sakka K, Kosugi A, Mori Y. 2013. Strain B-6 Multienzyme Complex: A Novel System for Biomass Utilization.Biomass Now-cultivation and utilization.

38. Maitan-Alfenas GP, Visser EM, Guimarães VM. 2014. Enzymatic Hydrolysis of Lignocellulosic Biomass: Converting Food Waste in Valuable Products. Curr. Opin. Food Sci.

39. Kumar P, Barrett DM, Delwiche MJ, Stroeve P. 2009. Methods for Pretreatment of Lignocellulosic Biomass for Efficient Hydrolysis and Biofuel Production. Ind. Eng. Chem. Res. 48:3713-3729.

40. Ullah K, Kumar Sharma V, Dhingra S, Braccio G, Ahmad M, Sofia S. 2015. Assessing the lignocellulosic biomass resources potential in developing countries: A critical review. Renew. Sustain. Energy Rev. 51:682-698.

41. Hall M, Bansal P, Lee JH, Realff MJ, Bommarius AS. 2010. Cellulose crystallinity - A key predictor of the enzymatic hydrolysis rate. FEBS J. 277:1571-1582.

42. Margeot A, Hahn-Hagerdal B, Edlund M, Slade R, Monot F. 2009. New improvements for lignocellulosic ethanol. Curr. Opin. Biotechnol. 20:372-80.

43. Yang B, Wyman CE. 2008. Pretreatment: the key to unlocking low-cost cellulosic ethanol. Biofuels, Bioprod. Biorefining 2:26-40.

44. Shi J, George KW, Sun N, He W, Li C, Stavila V, Keasling JD, Simmons B, Lee TS, Singh S. 2015. Impact of Pretreatment Technologies on Saccharification and Isopentenol Fermentation of Mixed Lignocellulosic Feedstocks. BioEnergy Res.

45. Brodeur G, Yau E, Badal K, Collier J, Ramachandran KB, Ramakrishnan S. 2011. Chemical and physicochemical pretreatment of lignocellulosic biomass: a review. Enzyme Res. 2011:787532.

46. Stephanopoulos G. 2007. Challenges in engineering microbes for biofuels production. Science 315:801-4.

47. Kricka W, Fitzpatrick J, Bond U. 2015. Challenges for the production of bioethanol from biomass using recombinant yeasts.Advances in applied microbiology. Elsevier.

48. Field SJ, Ryden P, Wilson D, James S A, Roberts IN, Richardson DJ, Waldron KW, Clarke T A. 2015. Identification of furfural resistant strains of Saccharomyces cerevisiae and Saccharomyces paradoxus from a collection of environmental and industrial isolates. Biotechnol. Biofuels 8:33.

49. Piotrowski JS, Zhang Y, Bates DM, Keating DH, Sato TK, Ong IM, Landick R. 2014. Death by a thousand cuts: the challenges and diverse landscape of lignocellulosic hydrolysate inhibitors. Front. Microbiol. 5.

50. Klinke HB, Olsson L, Thomsen AB, Ahring BK. 2003. Potential inhibitors from wet oxidation of wheat straw and their effect on ethanol production of Saccharomyces cerevisiae: wet oxidation and fermentation by yeast. Biotechnol. Bioeng. 81:738-747.

51. Palmqvist E, Hahn-Hägerdal B. 2000. Fermentation of lignocellulosic hydrolysates. II: inhibitors and mechanisms of inhibition. Bioresour. Technol. 74:25-33. 
52. Bhat MK. 2000. Cellulases and related enzymes in biotechnology. Biotechnol. Adv. 18:355383.

53. Phitsuwan P, Laohakunjit N, Kerdchoechuen O, Kyu KL, Ratanakhanokchai K. 2013. Present and potential applications of cellulases in agriculture, biotechnology, and bioenergy. Folia Microbiol. (Praha). 58:163-76.

54. Gautam SP, Bundela PS, Pandey AK, Awasthi MK, Sarsaiya S. 2012. Diversity of cellulolytic microbes and the biodegradation of municipal solid waste by a potential strain. Int. J. Microbiol. 2012.

55. Eriksson K-EL, Blanchette R, Ander P. 2012. Microbial and enzymatic degradation of wood and wood components. Springer Science \& Business Media.

56. Kaffenberger JT, Schilling JS. 2014. Comparing lignocellulosephysiochemistry after decomposition by brown rot fungi with distinct evolutionary origins. Environ. Microbiol.

57. Henriksson G., Johansson G. and Pettersson G. 2000. A critical review of cellobiose dehydrogenases. Journal of Biotechnology, 78:2, pp.93-113.

58. Kostylev M, Wilson D. 2012. Synergistic interactions in cellulose hydrolysis. Biofuels 3:6170 .

59. Hemsworth GR, Henrissat B, Davies GJ, Walton PH. 2014. Discovery and characterization of a new family of lytic polysaccharide monooxygenases. Nat Chem Biol 10:122-126.

60. Agger JW, Isaksen T, Várnai A, Vidal-Melgosa S, Willats WGT, Ludwig R, Horn SJ, Eijsink VGH, Westereng B. 2014. Discovery of LPMO activity on hemicelluloses shows the importance of oxidative processes in plant cell wall degradation. Proc. Natl. Acad. Sci. 111:6287-6292.

61. Kuhad RC, Gupta R, Singh A. 2011. Microbial cellulases and their industrial applications. Enzyme Res. 2011:280696.

62. Kubicek CP. 1993. Proceedings of the second TRICEL symposium on Trichoderma reesei cellulases and other hydrolytic enzymes. From cellulose to cellulase inducers: facts and fiction, p. $181-188$.

63. Henrissat B, Teeri TT, Warren RAJ. 1998. A scheme for designating enzymes that hydrolyse the polysaccharides in the cell walls of plants. Febs Lett. 425:352-354.

64. Cantarel BL, Coutinho PM, Rancurel C, Bernard T, Lombard V, Henrissat B. 2009. The Carbohydrate-Active EnZymes database (CAZy): an expert resource for glycogenomics. Nucleic Acids Res. 37:D233-D238.

65. Hu J, Arantes V, Pribowo A, Saddler JN. 2013. The synergistic action of accessory enzymes enhances the hydrolytic potential of a "cellulase mixture" but is highly substrate specific. Biotechnol. Biofuels 6:112.

66. Voutilainen SP, Murray PG, Tuohy MG, Koivula A. 2010. Expression of Talaromyces emersonii cellobiohydrolase Cel7A in Saccharomyces cerevisiae and rational mutagenesis to improve its thermostability and activity. Protein Eng. Des. Sel. 23:69-79. 
67. Njokweni A P, Rose SH, van Zyl WH. 2012. Fungal $\beta$-glucosidase expression in Saccharomyces cerevisiae. J. Ind. Microbiol. Biotechnol. 39:1445-52.

68. Ilmén M, den Haan R, Brevnova E, McBride J, Wiswall E, Froehlich A, Koivula A, Voutilainen SP, Siika-Aho M, la Grange DC, Thorngren N, Ahlgren S, Mellon M, Deleault K, Rajgarhia V, van Zyl WH, Penttilä M. 2011. High level secretion of cellobiohydrolases by Saccharomyces cerevisiae. Biotechnol. Biofuels 4:30.

69. Den Haan R, Mcbride JE, Grange DC La, Lynd LR, Van Zyl WH. 2007. Functional expression of cellobiohydrolases in Saccharomyces cerevisiae towards one-step conversion of cellulose to ethanol. Enzyme Microb. Technol. 40:1291-1299.

70. Lee TM, Farrow MF, Arnold FH, Mayo SL. 2011. A structural study of Hypocrea jecorina Cel5A. Protein Sci. 20:1935-40.

71. La Grange DC, Pretorius IS, van Zyl WH. 1996. Expression of a Trichoderma reesei betaxylanase gene (XYN2) in Saccharomyces cerevisiae. Appl. Environ. Microbiol. 62:1036-1044.

72. Pereira JH, Chen Z, McAndrew RP, Sapra R, Chhabra SR, Sale KL, Simmons BA, Adams PD. 2010. Biochemical characterization and crystal structure of endoglucanase Cel5A from the hyperthermophilic Thermotoga maritima. J. Struct. Biol. 172:372-379.

73. Van Zyl JM, van Rensburg E, van Zyl WH, Harms TM, Lynd LR. 2011. A kinetic model for simultaneous saccharification and fermentation of Avicel with Saccharomyces cerevisiae. Biotechnol. Bioeng. 108:924-33.

74. Teeri TT. 1996. Crystalline cellulose degradation: new insight into the function of cellobiohydrolases . Trends in Biotech. G3 7799:141-148.

75. Divne C, Ståhlberg J, Teeri TT, Jones TA. 1998. High-resolution crystal structures reveal how a cellulose chain is bound in the $50 \AA$ long tunnel of cellobiohydrolase I from Trichoderma reesei. J. Mol. Biol. 275:309-325.

76. Parkkinen L, Pirttilä T, Alafuzoff I. 2008. Applicability of current staging/categorization of $\alpha$-synuclein pathology and their clinical relevance. Acta Neuropathol. 115:399-407.

77. Bevan DR, Henrissat B, Esen A, Czjzek M, Cicek M. 2000. The mechanism of substrate ( aglycone ) specificity in beta -glucosidases is revealed by crystal structures of mutant maize beta-glucosidase. The EMBO journal 6: 1396-1405.

78. Yang B, Dai Z, Ding S-Y, Wyman CE. 2011. Enzymatic hydrolysis of cellulosic biomass. Biofuels 2:421-449.

79. Gurgu L, Lafraya Á, Polaina J, Marín-Navarro J. 2011. Fermentation of cellobiose to ethanol by industrial Saccharomyces strains carrying the $\beta$-glucosidase gene (BGL1) from Saccharomycopsis fibuligera. Bioresour. Technol. 102:5229-36.

80. Zhang L, Guo Z, Hong J, Ding Z, Gao Z, He Z, Shi G. 2011. Expressing $\beta$-glucosidase from Saccharomycopsis fibuligera in industrial ethanol producing yeast and evaluation of the expressing sufficiency. Ann. Microbiol. 62:539-544.

81. Pandey A. 2011. Biofuels: alternative feedstocks and conversion processes. Academic Press. 
82. Adrio JL, Demain AL. 2014. Microbial enzymes: Tools for biotechnological processes. Biomolecules 4:117-139.

83. Ma A, Hu Q, Qu Y, Bai Z, Liu W, Zhuang G. 2008. The enzymatic hydrolysis rate of cellulose decreases with irreversible adsorption of cellobiohydrolase I. Enzyme Microb. Technol. 42:543547.

84. Rahikainen J, Mikander S, Marjamaa K, Tamminen T, Lappas A, Viikari L, Kruus K. 2011. Inhibition of enzymatic hydrolysis by residual lignins from softwood-study of enzyme binding and inactivation on lignin-rich surface. Biotechnol. Bioeng. 108:2823-2834.

85. Skory CD, Freer SN, Bothast RJ. 1996. Expression and secretion of the Candida wickerhamii extracellular beta-glucosidase gene, bglB, in Saccharomyces cerevisiae. Curr. Genet. 30:41722.

86. Xiao Z, Zhang X, Gregg DJ, Saddler JN. 2004. Effects of sugar inhibition on cellulases and $\beta$-glucosidase during enzymatic hydrolysis of softwood substrates, p. 1115-1126. In Proceedings of the Twenty-Fifth Symposium on Biotechnology for Fuels and Chemicals Held May 4-7, 2003, in Breckenridge, CO. Springer.

87. Howell JA, Mangat M. 1978. Enzyme deactivation during cellulose hydrolysis. Biotechnol. Bioeng. 20:847-863.

88. Qing Q, Yang B, Wyman CE. 2010. Xylooligomers are strong inhibitors of cellulose hydrolysis by enzymes. Bioresour. Technol. 101:9624-9630.

89. Mansfield SD, Mooney C, Saddler JN. 1999. Substrate and enzyme characteristics that limit cellulose hydrolysis. Biotechnol. Prog. 15:804-816.

90. Fan LT, Lee Y, Beardmore DH. 1980. Mechanism of the enzymatic hydrolysis of cellulose: effects of major structural features of cellulose on enzymatic hydrolysis. Biotechnol. Bioeng. 22:177-199.

91. Zhang Y-HP, Lynd LR. 2004. Toward an aggregated understanding of enzymatic hydrolysis of cellulose: noncomplexed cellulase systems. Biotechnol. Bioeng. 88:797-824.

92. Kang I-S, Yang CQ, Wei W, Lickfield GC. 1998. Mechanical strength of durable press finished cotton fabrics part I: effects of acid degradation and crosslinking of cellulose by polycarboxylic acids. Text. Res. J. 68:865-870.

93. Zhu L, O'Dwyer JP, Chang VS, Granda CB, Holtzapple MT. 2008. Structural features affecting biomass enzymatic digestibility. Bioresour. Technol. 99:3817-3828.

94. Yang B, Willies DM, Wyman CE. 2006. Changes in the Enzymatic Hydrolysis Rate of Avicel Cellulose With Conversion. Biotech. and Bioengin. 6: 1122-1128.

95. Olson DG, McBride JE, Shaw A J, Lynd LR. 2012. Recent progress in consolidated bioprocessing. Curr. Opin. Biotechnol. 23:396-405.

96. De Baetselier A, Vasavada A, Dohet P, Ha-Thi V, De Beukelaer M, Erpicum T, De Clerck L, Hanotier J, Rosenberg S. 1991. Fermentation of a yeast producing A. niger glucose oxidase: scale-up, purification and characterization of the recombinant enzyme. Nat. Biotechnol. 9:559561. 
97. Fitzpatrick J, Kricka W, James TC, Bond U. 2014. Expression of three Trichoderma reesei cellulase genes in Saccharomyces pastorianus for the development of a two-step process of hydrolysis and fermentation of cellulose. J. Appl. Microbiol. 117:96-108.

98. Wieczorek AS, Biot-pelletier D, Martin VJJ. 2013. Recombinant Cellulase and Cellulosome Systems. Edited by Theo van de Ven and John Kadla, 101.

99. Medve J, Karlsson J, Lee D, Tjerneld F. 1998. Hydrolysis of microcrystalline cellulose by cellobiohydrolase I and endoglucanase II from Trichoderma reesei: adsorption, sugar production pattern, and synergism of the enzymes. Biotechnol. Bioeng. 59:621-634.

100. Kleman-Leyer KM, SiiKa-Aho M, Teeri TT, Kirk TK. 1996. The Cellulases Endoglucanase I and Cellobiohydrolase II of Trichoderma reesei Act Synergistically To Solubilize Native Cotton Cellulose but Not To Decrease Its Molecular Size. Appl. Environ. Microbiol. 62:28832887.

101. Spada CS, Woodward DF, Hawley SB, Nieves AL, Williams LS, Feldmann BJ. 1988. Synergistic effects of LTB4 and LTD4 on leukocyte emigration into the guinea pig conjunctiva. Am. J. Pathol. 130:354.

102. Den Haan R, Rose SH, Lynd LR, van Zyl WH. 2007. Hydrolysis and fermentation of amorphous cellulose by recombinant Saccharomyces cerevisiae. Metab. Eng. 9:87-94.

103. Yamada R, Taniguchi N, Tanaka T, Ogino C, Fukuda H, Kondo A. 2010. Cocktail deltaintegration: a novel method to construct cellulolytic enzyme expression ratio-optimized yeast strains. Microb. Cell Fact. 9:32.

104. Axelsson J. 2011. Separate Hydrolysis and Fermentation of Pretreated Spruce Separate Hydrolysis and Fermentation of Pretreated Spruce.

105. Diaz JT, Chinn MS, Truong V-D. 2014. Simultaneous saccharification and fermentation of industrial sweetpotatoes for ethanol production and anthocyanins extraction. Ind. Crops Prod. 62:53-60.

106. Dashtban M, Schraft H, Qin W. 2009. Fungal bioconversion of lignocellulosic residues; opportunities \& perspectives. Int. J. Biol. Sci. 5:578.

107. Takagi M, Abe S, Suzuki S, Emert G, Yata N. 1977. A method for production of alcohol directly from cellulose using cellulase and yeast, p. 551-571. In Bioconversion Symposium; New Dehli, India.

108. Sun Y, Cheng J. 2002. Hydrolysis of lignocellulosic materials for ethanol production: a review. Bioresour. Technol. 83:1-11.

109. Mukherjee V, Steensels J, Lievens B, Van de Voorde I, Verplaetse A, Aerts G, Willems K A, Thevelein JM, Verstrepen KJ, Ruyters S. 2014. Phenotypic evaluation of natural and industrial Saccharomyces yeasts for different traits desirable in industrial bioethanol production. Appl. Microbiol. Biotechnol.

110. Nicolaou S A, Gaida SM, Papoutsakis ET. 2010. A comparative view of metabolite and substrate stress and tolerance in microbial bioprocessing: From biofuels and chemicals, to biocatalysis and bioremediation. Metab. Eng. 12:307-31. 
111. Kauffman KJ, Pridgen EM, Doyle FJ, Dhurjati PS, Robinson AS. 2002. Decreased protein expression and intermittent recoveries in BiP levels result from cellular stress during heterologous protein expression in Saccharomyces cerevisiae. Biotechnol. Prog. 18:942-950.

112. Gasch AP. 2003. The environmental stress response: a common yeast response to diverse environmental stresses. In Yeast stress responses .pp. 11-70. Springer Berlin Heidelberg.

113. Hohmann S. 2002. Osmotic Stress Signaling and Osmoadaptation in Yeasts. Micro and molecular bio reviews. 66:300-372.

114. Bauer EF, Pretorius LS. 2000. Yeast Stress Response and Fermentation Efficiency : How to Survive the Making of Wine - A Review. South African J. Enol. Vitic. 21:27-51.

115. Swan TM, Watson K. 1999. Stress tolerance in a yeast lipid mutant: membrane lipids influence tolerance to heat and ethanol independently of heat shock proteins and trehalose. Can. J. Microbiol. 45:472-479.

116. Harding HP, Novoa I, Zhang Y, Zeng H, Wek R, Schapira M, Ron D. 2000. Regulated translation initiation controls stress-induced gene expression in mammalian cells. Mol. Cell 6:1099-1108.

117. Takagi H. 2008. Proline as a stress protectant in yeast: physiological functions, metabolic regulations, and biotechnological applications. Appl. Microbiol. Biotechnol. 81:211-223.

118. Majara M, O'Connor-Cox ESC, Axcell BC. 1996. Trehalose--a stress protectant and stress indicator compound for yeast exposed to adverse conditions. J. Am. Soc. Brew. Chem.136: 395403.

119. Verduyn, C., Postma, E., Scheffers, W.A. and van Dijken, J.P. 1990. Physiology of Saccharomyces Cerevisiae in Anaerobic Glucose-Limited Chemostat Cultures. Microbiology, 136:3, pp.395-403.

120. Koppram R, Tomás-Pejó E, Xiros C, Olsson L. 2014. Lignocellulosic ethanol production at high-gravity: challenges and perspectives. Trends Biotechnol. 32:46-53.

121. Causton HC, Ren B, Koh SS, Harbison CT, Kanin E, Jennings EG, Lee TI, True HL, Lander ES, Young RA. 2001. Remodeling of yeast genome expression in response to environmental changes. Mol. Biol. Cell 12:323-337.

122. Causton HC, Ren B, Koh SS, Harbison CT, Kanin E, Jennings EG, Lee TI, True HL, Lander ES, Young R A. 2001. Remodeling of yeast genome expression in response to environmental changes. Mol. Biol. Cell 12:323-37.

123. Berry DB, Guan Q, Hose J, Haroon S, Gebbia M, Heisler LE, Nislow C, Giaever G, Gasch AP. 2011. Multiple means to the same end: the genetic basis of acquired stress resistance in yeast. PLoS Genet. 7:e1002353.

124. Morano K A, Grant CM, Moye-Rowley WS. 2012. The response to heat shock and oxidative stress in Saccharomyces cerevisiae. Genetics 190:1157-95.

125. Ding M-Z, Wang X, Liu W, Cheng J-S, Yang Y, Yuan Y-J. 2012. Proteomic research reveals the stress response and detoxification of yeast to combined inhibitors. PLoS One 7:e43474. 
126. Gasser B, Saloheimo M, Rinas U, Dragosits M, Rodríguez-Carmona E, Baumann K, Giuliani M, Parrilli E, Branduardi P, Lang C, Porro D, Ferrer P, Tutino ML, Mattanovich D, Villaverde A. 2008. Protein folding and conformational stress in microbial cells producing recombinant proteins: a host comparative overview. Microb. Cell Fact. 7:11.

127. Mattanovich D, Gasser B, Hohenblum H, Sauer M. 2004. Stress in recombinant protein producing yeasts. J. Biotechnol. 113:121-35.

128. Liu Y, Chang A. 2008. Heat shock response relieves ER stress. EMBO J. 27:1049-1059.

129. Hou J, Osterlund T, Liu Z, Petranovic D, Nielsen J. 2013. Heat shock response improves heterologous protein secretion in Saccharomyces cerevisiae. Appl. Microbiol. Biotechnol. 97:3559-68.

130. Clark JH, Deswarte F. 2015. Introduction to chemicals from biomass. John Wiley \& Sons.

131. Shock TR, Thompson J, Yates JR, Madhani HD. 2009. Hog1 mitogen-activated protein kinase (MAPK) interrupts signal transduction between the Kss1 MAPK and the Tec1 transcription factor to maintain pathway specificity. Eukaryot. Cell 8:606-16.

132. Favaro L, Basaglia M, Trento A, Van Rensburg E, García-Aparicio M, Van Zyl WH, Casella S. 2013. Exploring grape marc as trove for new thermotolerant and inhibitor-tolerant Saccharomyces cerevisiae strains for second-generation bioethanol production. Biotechnol. Biofuels 6:168.

133. Kvitek DJ, Will JL, Gasch AP. 2008. Variations in stress sensitivity and genomic expression in diverse S. cerevisiae isolates. PLoS Genet. 4:e1000223.

134. Ruyters S, Mukherjee V, Verstrepen KJ, Thevelein JM, Willems K A, Lievens B. 2014. Assessing the potential of wild yeasts for bioethanol production. J. Ind. Microbiol. Biotechnol. $1-10$.

135. Wohlbach DJ, Rovinskiy N, Lewis J A, Sardi M, Schackwitz WS, Martin J A, Deshpande S, Daum CG, Lipzen A, Sato TK, Gasch AP. 2014. Comparative genomics of Saccharomyces cerevisiae natural isolates for bioenergy production. Genome Biol. Evol.

136. Pereira FB, Romaní A, Ruiz H A, Teixeira J A, Domingues L. 2014. Industrial robust yeast isolates with great potential for fermentation of lignocellulosic biomass. Bioresour. Technol. 161:192-9.

137. Ramos CL, Duarte WF, Freire AL, Dias DR, Cristina E, Eleutherio A, Schwan RF. 2013. Evaluation of stress tolerance and fermentative behavior of indigenous Saccharomyces cerevisiae 944:935-944.

138. Garay-Arroyo A, Covarrubias AA, Clark I, Niño I, Gosset G, Martinez A. 2004. Response to different environmental stress conditions of industrial and laboratory Saccharomyces cerevisiae strains. Appl. Microbiol. Biotechnol. 63:734-41.

139. Martín C. and Jönsson L.J, 2003. Comparison of the resistance of industrial and laboratory strains of Saccharomyces and Zygosaccharomyces to lignocellulose-derived fermentation inhibitors. Enzyme and Microbial Technology, 32:3, 386-395. 
140. Favaro L, Viktor MJ, Rose SH, Viljoen-Bloom M, van Zyl WH, Basaglia M, Cagnin L, Casella S. 2015. Consolidated bioprocessing of starchy substrates into ethanol by industrial Saccharomyces cerevisiae strains secreting fungal amylases. Biotechnol. Bioeng.

141. Marín-Navarro J, Gurgu L, Alamar S, Polaina J. 2011. Structural and functional analysis of hybrid enzymes generated by domain shuffling between Saccharomyces cerevisiae (var. diastaticus) Sta1 glucoamylase and Saccharomycopsis fibuligera Bgl1 $\beta$-glucosidase. Appl. Microbiol. Biotechnol. 89:121-30.

142. Ziv N, Siegal ML, Gresham D. 2013. Genetic and nongenetic determinants of cell growth variation assessed by high-throughput microscopy. Mol. Biol. Evol. 30:2568-2578.

143. Celik E, Calık P. 2012. Production of recombinant proteins by yeast cells. Biotechnol. Adv. 30:1108-18.

144. Nevalainen KMH, Te'o VSJ, Bergquist PL. 2005. Heterologous protein expression in filamentous fungi. Trends Biotechnol. 23:468-74.

145. Kavšček M, Stražar M, Curk T, Natter K, Petrovič U. 2015. Yeast as a cell factory: current state and perspectives. Microb. Cell Fact. 14:94.

146. Gopal GJ, Kumar A. 2013. Strategies for the production of recombinant protein in Escherichia coli. Protein J. 32:419-425.

147. Gupta S, Adlakha N, Yazdani SS. 2013. Efficient extracellular secretion of an endoglucanase and a Beta-glucosidase in E. coli. Protein Expr. Purif. 88:20-25.

148. Demain AL, Vaishnav P. 2009. Production of recombinant proteins by microbes and higher organisms. Biotechnol. Adv. 27:297-306.

149. McGovern PE, Zhang J, Tang J, Zhang Z, Hall GR, Moreau R A, Nuñez A, Butrym ED, Richards MP, Wang C-S, Cheng G, Zhao Z, Wang C. 2004. Fermented beverages of pre- and proto-historic China. Proc. Natl. Acad. Sci. U. S. A. 101:17593-8.

150. Cavalieri D, Townsend JP, Hartl DL. 2000. Manifold anomalies in gene expression in a vineyard isolate of Saccharomyces cerevisiae revealed by DNA microarray analysis. Proc. Natl. Acad. Sci. U. S. A. 97:12369-74.

151. Dunn B, Richter C, Kvitek DJ, Pugh T, Sherlock G. 2012. Analysis of the Saccharomyces cerevisiae pan-genome reveals a pool of copy number variants distributed in diverse yeast strains from differing industrial environments. Genome Res. 22:908-24.

152. June C, Page SEEL, Kammen DM. 2006. Ethanol can contribute and environmental Goals.Science. 311:506-508.

153. Demeke MM, Dietz H, Li Y, Foulquié-Moreno MR, Mutturi S, Deprez S, Den Abt T, Bonini BM, Liden G, Dumortier F. 2013. Development of a D-xylose fermenting and inhibitor tolerant industrial Saccharomyces cerevisiae strain with high performance in lignocellulose hydrolysates using metabolic and evolutionary engineering. Biotechnol Biofuels 6:89.

154. Den Haan R, van Rensburg E, Rose SH, Görgens JF, van Zyl WH. 2014. Progress and challenges in the engineering of non-cellulolytic microorganisms for consolidated bioprocessing. Curr. Opin. Biotechnol. 33C:32-38. 
155. Finkelstein M, Davison BH. 2012. Twenty-First Symposium on Biotechnology for Fuels and Chemicals: Held May 2-6, 1999, in Fort Collins, Colorado. Springer Science \& Business Media.

156. Talebnia F, Karakashev D, Angelidaki I. 2010. Production of bioethanol from wheat straw: an overview on pretreatment, hydrolysis and fermentation. Bioresour. Technol. 101:4744-4753.

157. Park JM, Oh B-R, Seo J-W, Hong W-K, Yu A, Sohn J-H, Kim CH. 2013. Efficient production of ethanol from empty palm fruit bunch fibers by fed-batch simultaneous saccharification and fermentation using Saccharomyces cerevisiae. Appl. Biochem. Biotechnol. 170:1807-1814.

158. Geddes CC, Nieves IU, Ingram LO. 2011. Advances in ethanol production. Curr. Opin. Biotechnol. 22:312-319.

159. Xu L, Shen Y, Hou J, Peng B, Tang H, Bao X. 2014. Secretory pathway engineering enhances secretion of cellobiohydrolase I from Trichoderma reesei in Saccharomyces cerevisiae. J. Biosci. Bioeng. 117:45-52.

160. Basso LC, de Amorim HV, de Oliveira AJ, Lopes ML. 2008. Yeast selection for fuel ethanol production in Brazil. FEMS Yeast Res. 8:1155-63.

161. Kim S-K, Jin Y-S, Choi I-G, Park Y-C, Seo J-H. 2015. Enhanced tolerance of Saccharomyces cerevisiae to multiple lignocellulose-derived inhibitors through modulation of spermidine contents. Metab. Eng. 1-10.

162. Zaki A M, Wimalasena TT, Greetham D. 2014. Phenotypic characterisation of Saccharomyces spp. for tolerance to 1-butanol. J. Ind. Microbiol. Biotechnol.

163. Madhavan A, Srivastava A, Kondo A, Bisaria VS. 2012. Bioconversion of lignocellulosederived sugars to ethanol by engineered Saccharomyces cerevisiae. Crit. Rev. Biotechnol. 32:22-48.

164. Wenger JW, Schwartz K, Sherlock G. 2010. Bulk segregant analysis by high-throughput sequencing reveals a novel xylose utilization gene from Saccharomyces cerevisiae. PLoS Genet 6:e1000942.

165. Reinhold-Hurek B, Hurek T, Claeyssens M, Van Montagu M. 1993. Cloning, expression in Escherichia coli, and characterization of cellulolytic enzymes of Azoarcus sp., a root-invading diazotroph. J. Bacteriol. 175:7056-7065.

166. Flint HJ, McPherson CA, Martin J. 1991. Expression of two xylanase genes from the rumen cellulolytic bacterium Ruminococcus flavefaciens 17 cloned in pUC13. J. Gen. Microbiol. 137:123-129.

167. Cho HP, Nakamura MT, Clarke SD. 1999. Cloning, expression, and nutritional regulation of the mammalian $\Delta-6$ desaturase. J. Biol. Chem. 274:471-477.

168. La Grange DC, den Haan R, van Zyl WH. 2010. Engineering cellulolytic ability into bioprocessing organisms. Appl. Microbiol. Biotechnol. 87:1195-208.

169. Cho, Kwang Myung, Young Je Yoo, and Hyen Sam Kang.1999. $\delta$-Integration of endo/exoglucanase and $\beta$-glucosidase genes into the yeast chromosomes for direct conversion of cellulose to ethanol. Enzyme and Microbial Technology.1: 23-30. 
170. Wen F, Sun J, Zhao H. 2010. Yeast surface display of trifunctional minicellulosomes for simultaneous saccharification and fermentation of cellulose to ethanol. Appl. Environ. Microbiol. 76:1251-60.

171. Yamada R, Taniguchi N, Tanaka T, Ogino C, Fukuda H, Kondo A. 2011. Direct ethanol production from cellulosic materials using a diploid strain of Saccharomyces cerevisiae with optimized cellulase expression. Biotechnol. Biofuels 4:8.

172. Bayer EA, Morag E, Lamed R. 1994. The cellulosome-a treasure-trove for biotechnology. Trends Biotechnol. 12:379-386.

173. Van Rooyen R, Hahn-Hägerdal B, La Grange DC, van Zyl WH. 2005. Construction of cellobiose-growing and fermenting Saccharomyces cerevisiae strains. J. Biotechnol. 120:28495.

174. Du Plessis L, Rose SH, van Zyl WH. 2010. Exploring improved endoglucanase expression in Saccharomyces cerevisiae strains. Appl. Microbiol. Biotechnol. 86:1503-11.

175. Den Haan R, van Zyl JM, Harms TM, van Zyl WH. 2013. Modeling the minimum enzymatic requirements for optimal cellulose conversion. Environ. Res. Lett. 8:025013.

176. Linger JG, Adney WS, Darzins A. 2010. Heterologous expression and extracellular secretion of cellulolytic enzymes by Zymomonas mobilis. Appl. Environ. Microbiol. 76:6360-9.

177. Tanaka T, Kondo A. 2014. Cell-surface display of enzymes by the yeast Saccharomyces cerevisiae for synthetic biology. FEMS Yeast Res.

178. Jeon E, Hyeon JE, Eun LS, Park B-S, Kim SW, Lee J, Han SO. 2009. Cellulosic alcoholic fermentation using recombinant Saccharomyces cerevisiae engineered for the production of Clostridium cellulovorans endoglucanase and Saccharomycopsis fibuligera beta-glucosidase. FEMS Microbiol. Lett. 301:130-6.

179. Van Rensburg E, den Haan R, Smith J, van Zyl WH, Görgens JF. 2012. The metabolic burden of cellulase expression by recombinant Saccharomyces cerevisiae Y294 in aerobic batch culture. Appl. Microbiol. Biotechnol. 96:197-209.

180. Baek S-H, Kim S, Lee K, Lee J-K, Hahn J-S. 2012. Cellulosic ethanol production by combination of cellulase-displaying yeast cells. Enzyme Microb. Technol. 51:366-72.

181. Wei H, Wang W, Alahuhta M, Vander Wall T, Baker JO, Taylor LE, Decker SR, Himmel ME, Zhang M. 2014. Engineering towards a complete heterologous cellulase secretome in Yarrowia lipolytica reveals its potential for consolidated bioprocessing. Biotechnol. Biofuels 7:148.

182. Kroukamp H. 2015. Improving the protein secretion capacity of Saccharomyces cerevisiae with strain engineering. Disssertation for PhD. Stellenbosch University.

183. Kroukamp H, den Haan R, van Wyk N, van Zyl WH. 2013. Overexpression of native PSE1 and SOD1 in Saccharomyces cerevisiae improved heterologous cellulase secretion. Appl. Energy 102:150-156.

184. Yu P, Zhu Q, Chen K, Lv X. 2014. Improving the Secretory Production of the Heterologous Protein in Pichia pastoris by Focusing on Protein Folding. Appl. Biochem. Biotechnol. 
185. Ruohonen L, Toikkanen J, Tieaho V, Outola M, Soderlund H, Keranen S. 1997. Enhancement of protein secretion in Saccharomyces cerevisiae by overproduction of Sso protein, a late-acting component of the secretory machinery. Yeast 13:337-51.

186. Idiris A, Tohda H, Kumagai H, Takegawa K. 2010. Engineering of protein secretion in yeast: strategies and impact on protein production. Appl. Microbiol. Biotechnol. 86:403-17.

187. Wang T-Y, Huang C-J, Chen H-L, Ho P-C, Ke H-M, Cho H-Y, Ruan S-K, Hung K-Y, Wang I-L, Cai Y-W, Sung H-M, Li W-H, Shih M-C. 2013. Systematic screening of glycosylation- and trafficking-associated gene knockouts in Saccharomyces cerevisiae identifies mutants with improved heterologous exocellulase activity and host secretion. BMC Biotechnol. 13:71.

188. Cudna RE, Dickson AJ. 2003. Endoplasmic reticulum signaling as a determinant of recombinant protein expression. Biotechnol. Bioeng. 81:56-65.

189. Arvas M, Pakula T, Lanthaler K, Saloheimo M, Valkonen M, Suortti T, Robson G, Penttilä M. 2006. Common features and interesting differences in transcriptional responses to secretion stress in the fungi Trichoderma reesei and Saccharomyces cerevisiae. BMC Genomics 7:32.

190. Bull VH, Thiede B. 2012. Proteome analysis of tunicamycin-induced ER stress. Electrophoresis 33:1814-23.

191. Ballou L, Hitzeman RA, Lewis MS, Ballou CE. 1991. Vanadate-resistant yeast mutants are defective in protein glycosylation. Proc. Natl. Acad. Sci. U. S. A. 88:3209-12.

192. Toikkanen J. 2001. Powerpoint presentation. Expression of proteins in yeast systems. VTT Biotechnology Seminar.

193. Schröder M, Kaufman RJ. 2005. The mammalian unfolded protein response. Annu. Rev. Biochem. 74:739-89.

194. Gasmi N, Ayed A, Nicaud J-M, Kallel H. 2011. Design of an efficient medium for heterologous protein production in Yarrowia lipolytica: case of human interferon alpha $2 b$. Microb. Cell Fact. 10:38.

195. Hahn-Hägerdal B, Karhumaa K, Larsson CU, Gorwa-Grauslund M, Görgens J, van Zyl WH. 2005. Role of cultivation media in the development of yeast strains for large scale industrial use. Microb. Cell Fact. 4:31.

196. Bernaudat F, Frelet-Barrand A, Pochon N, Dementin S, Hivin P, Boutigny S, Rioux J-B, Salvi D, Seigneurin-Berny D, Richaud P, Joyard J, Pignol D, Sabaty M, Desnos T, PebayPeyroula E, Darrouzet E, Vernet T, Rolland N. 2011. Heterologous expression of membrane proteins: choosing the appropriate host. PLoS One 6:e29191.

197. Tew JG, Mandel TE. 1979. Prolonged antigen half-life in the lymphoid follicles of specifically immunized mice. Immunology 37:69-76.

198. Burgess-Brown N A, Sharma S, Sobott F, Loenarz C, Oppermann U, Gileadi O. 2008. Codon optimization can improve expression of human genes in Escherichia coli: A multi-gene study. Protein Expr. Purif. 59:94-102. 
199. Mansur M, Cabello C, Hernández L, País J, Varas L, Valdés J, Terrero Y, Hidalgo A, Plana L, Besada V, García L, Lamazares E, Castellanos L, Martínez E. 2005. Multiple gene copy number enhances insulin precursor secretion in the yeast Pichia pastoris. Biotechnol. Lett. 27:339-45.

200. Baeyens J, Kang Q, Appels L, Dewil R, Lv Y, Tan T. 2015. Challenges and opportunities in improving the production of bio-ethanol. Prog. Energy Combust. Sci. 47:60-88.

201. Uzbas F, Sezerman U, Hartl L, Kubicek CP, Seiboth B. 2012. A homologous production system for Trichoderma reesei secreted proteins in a cellulase-free background. Appl. Microbiol. Biotechnol. 93:1601-8.

202. Kruszewska JS, Perlińska-lenart U, Górka-nieć W, Orłowski J, Zembek P, Palamarczyk G. 2008. Alterations in protein secretion caused by metabolic engineering of glycosylation pathways in fungi 55:447-456.

203. De Nadal E, Ammerer G, Posas F. 2011. Controlling gene expression in response to stress. Nat. Rev. Genet. 12:833-45.

204. Laxman S, Sutter BM, Wu X, Kumar S, Guo X, Trudgian DC, Mirzaei H, Tu BP. 2013. Sulfur amino acids regulate translational capacity and metabolic homeostasis through modulation of tRNA thiolation. Cell 154:416-429.

205. Mattanovich D, Gasser B, Hohenblum H, Sauer M. 2004. Stress in recombinant protein producing yeasts. Journal of Biotech. 113:121-135.

206. Kerry-Williams SM, Gilbert SC, Evans LR, Ballance DJ. 1998. Disruption of the Saccharomyces cerevisiae YAP3 gene reduces the proteolytic degradation of secreted recombinant human albumin. Yeast 14:161-169.

207. Hou J, Tyo KEJ, Liu Z, Petranovic D, Nielsen J. 2012. Metabolic engineering of recombinant protein secretion by Saccharomyces cerevisiae. FEMS Yeast Res. 12:491-510.

208. Li S-S, Cheng C, Li Z, Chen J-Y, Yan B, Han B-Z, Reeves M. 2010. Yeast species associated with wine grapes in China. Int. J. Food Microbiol. 138:85-90.

209. Romano P, Caruso M, Capece A, Lipani G, Paraggio M, Fiore C. 2003. Metabolic diversity of Saccharomyces cerevisiae strains from spontaneously fermented grape musts. World J. Microbiol. Biotechnol. 19:311-315.

210. Török T, Mortimer RK, Romano P, Suzzi G, Polsinelli M. 1996. Quest for wine yeasts-an old story revisited. J. Ind. Microbiol. 17:303-313.

211. Garijo P, Santamaría P, López R, Sanz S, Olarte C, Gutiérrez AR. 2008. The occurrence of fungi, yeasts and bacteria in the air of a Spanish winery during vintage. Int. J. Food Microbiol. 125:141-145.

212. Schuller D, Casal M. 2007. The genetic structure of fermentative vineyard-associated Saccharomyces cerevisiae populations revealed by microsatellite analysis. Antonie Van Leeuwenhoek 91:137-150. 
213. Mortimer RK, Romano P, Suzzi G, Polsinelli M. 1994. Genome renewal: a new phenomenon revealed from a genetic study of 43 strains of Saccharomyces cerevisiae derived from natural fermentation of grape musts. Yeast 10:1543-1552.

214. Lopandic K, Gangl H, Wallner E, Tscheik G, Leitner G, Querol A, Borth N, Breitenbach M, Prillinger H, Tiefenbrunner W. 2007. Genetically different wine yeasts isolated from Austrian vine-growing regions influence wine aroma differently and contain putative hybrids between Saccharomyces cerevisiae and Saccharomyces kudriavzevii. FEMS Yeast Res. 7:953965.

215. Versavaud A, Courcoux P, Roulland C, Dulau L, Hallet J-N. 1995. Genetic diversity and geographical distribution of wild Saccharomyces cerevisiae strains from the wine-producing area of Charentes, France. Appl. Environ. Microbiol. 61:3521-3529.

216. Skelly D A, Merrihew GE, Riffle M, Connelly CF, Kerr EO, Johansson M, Jaschob D, Graczyk B, Shulman NJ, Wakefield J, Cooper SJ, Fields S, Noble WS, Muller EGD, Davis TN, Dunham MJ, Maccoss MJ, Akey JM. 2013. Integrative phenomics reveals insight into the structure of phenotypic diversity in budding yeast. Genome Res. 23:1496-504.

217. Warringer J, Zörgö E, Cubillos F A, Zia A, Gjuvsland A, Simpson JT, Forsmark A, Durbin R, Omholt SW, Louis EJ, Liti G, Moses A, Blomberg A. 2011. Trait variation in yeast is defined by population history. PLoS Genet. 7:e1002111.

218. Albers E, Larsson C. 2009. A comparison of stress tolerance in YPD and industrial lignocellulose-based medium among industrial and laboratory yeast strains. J. Ind. Microbiol. Biotechnol. 36:1085-91.

219. Khramtsov N, McDade L, Amerik A, Yu E, Divatia K, Tikhonov A, Minto M, KabongoMubalamate G, Markovic Z, Ruiz-Martinez M, Henck S. 2011. Industrial yeast strain engineered to ferment ethanol from lignocellulosic biomass. Bioresour. Technol. 102:8310-3.

220. Romaní A, Pereira F, Johansson B, Domingues L. 2014. Metabolic engineering of Saccharomyces cerevisiae ethanol strains PE-2 and CAT-1 for efficient lignocellulosic fermentation. Bioresour. Technol. 179C:150-158.

221. Demeke MM, Dumortier F, Li Y, Broeckx T, Foulquié-Moreno MR, Thevelein JM. 2013. Combining inhibitor tolerance and D-xylose fermentation in industrial Saccharomyces cerevisiae for efficient lignocellulose-based bioethanol production. Biotechnol. Biofuels 6:120.

222. Swiegers JH, Pretorius IS. 2005. Yeast modulation of wine flavor. Adv. Appl. Microbiol. 57:131-75.

223. Lambrechts MG, Pretorius IS. 2000. Yeast and its Importance to Wine Aroma - A Review . South African journal for Enology and viticulture. 21:97-129

224. Garay-Arroyo A, Covarrubias AA, Clark I, Niño I, Gosset G, Martinez A. 2004. Response to different environmental stress conditions of industrial and laboratory Saccharomyces cerevisiae strains. Appl. Microbiol. Biotechnol. 63:734-41.

225. Lewis JA, Elkon IM, Mcgee MA, Higbee AJ, Gasch AP. 2010. Exploiting Natural Variation in Saccharomyces cerevisiae to Identify Genes for Increased Ethanol Resistance. Genetics 4: 1197-1205. 
226. Borneman AR, Desany B A, Riches D, Affourtit JP, Forgan AH, Pretorius IS, Egholm M, Chambers PJ. 2011. Whole-genome comparison reveals novel genetic elements that characterize the genome of industrial strains of Saccharomyces cerevisiae. PLoS Genet. 7:e1001287.

227. Kim HS, Fay JC. 2007. Genetic variation in the cysteine biosynthesis pathway causes sensitivity to pharmacological compounds. Proc. Natl. Acad. Sci. U. S. A. 104:19387-91.

228. da Silva-Filho, E. A., Dos Santos, S. K. B., do Monte Resende, A., de Morais, J. O. F., de Morais Jr, M. A., \& Simões, D. A. 2005. Yeast population dynamics of industrial fuel-ethanol fermentation process assessed by PCR-fingerprinting. Antonie van Leeuwenhoek. 88:1 13-23. 


\section{Chapter 3:}

Heterologous expression of cellulase genes in natural Saccharomyces cerevisiae strains

(Poster presentations at $27^{\text {th }}$ International Conference on Yeast Genetics and

Molecular Biology, and 32 $2^{\text {nd }}$ International Specialised Symposium on Yeasts) 


\title{
Heterologous expression of cellulase genes in natural Saccharomyces cerevisiae strains
}

\author{
Steffi A. Davison ${ }^{1}$, Riaan den $\mathrm{Haan}^{2}$, Willem H. van Zyl ${ }^{1}$ \\ ${ }^{1}$ Department of Microbiology, Stellenbosch University, Stellenbosch, South Africa \\ ${ }^{2}$ Department of Biotechnology, University of the Western Cape, Bellville, South Africa
}

\begin{abstract}
Enzyme cost is one of the main impediments of cellulosic ethanol production. One of the strategies to reduce enzyme cost is to engineer enzyme production capacity in a fermentative microorganism to enable consolidated bio-processing (CBP), thereby reducing the amount of bioreactors needed as all biologically mediated steps will be carried out simultaneously. One approach to satisfy the aim is to utilise a strain with a high secretory phenotype, high fermentative capacity as well as an innate robustness to bioethanol-specific stressors, including tolerance to products formed during pre-treatment and fermentation of lignocellulosic substrates. Saccharomyces cerevisiae is a robust fermentative yeast but has limitations as a potential CBP host, for example low secretion titers. In this study, we evaluated natural S. cerevisiae strains for superior secretion activity and other industrially relevant characteristics needed during the process of lignocellulosic ethanol production. Individual cellulolytic enzymes namely Saccharomycopsis fibuligera Cel3A ( $\beta$-glucosidase), Talaromyces emersonii Cel7A (cellobiohydrolase) and Trichoderma reesei Cel5A (endoglucanase) were utilised as reporter proteins. Natural strain YI13 was identified to have a high secretory phenotype, demonstrating a 3.7-fold and 3.5-fold higher Cel7A and Cel5A activity, respectively, compared to the reference strain S288c. This natural strain also demonstrated other industrially relevant characteristics such as growth vigour, high ethanol titer $(9.0 \mathrm{~g} / \mathrm{L})$, multi-tolerance to high temperatures $\left(37^{\circ} \mathrm{C}\right.$ and $\left.40^{\circ} \mathrm{C}\right)$, high ethanol tolerance $(10 \% \mathrm{w} / \mathrm{v})$ and high tolerance towards various concentrations of a cocktail of inhibitory compounds commonly found in lignocellulose hydrolysates. This study accentuates the value of natural $S$. cerevisiae strains to serve as potential robust and highly productive "chassis" organisms for future strain development for CBP production.
\end{abstract}




\subsection{Introduction}

In order for commercial lignocellulosic ethanol to be cost-competitive with other fuels, an increased rate and efficiency of lignocellulosic biomass conversion needs to be achieved $(1,2)$. Lignocellulosic biomass can be hydrolysed by cellulolytic enzymes to yield monomeric sugars which are converted to ethanol by fermentation (3). However, the external addition of large amounts of cellulolytic enzymes to the lignocellulosic substrate is needed due to (i) the presence of lignin, which links cellulose and hemicellulose together to form a recalcitrant barrier and (ii) the highly crystalline and compact structure of cellulose itself, making it recalcitrant and difficult to degrade $(3,4)$. One of the goals into using lignocellulosic biomass as substrate for production of bioethanol is engineering fermentative microorganisms to display high cellulolytic enzyme production capabilities $(5,6)$, thereby reducing global production costs as lower amounts of external enzymes will be required (3). Subsequently, this will also reduce the amount of bioreactors needed since the three steps of biomass bio-processing namely production of saccharolytic enzymes, hydrolysis of polysaccharides present in the pre-treated biomass, and fermentation of hexose and pentose sugars could be carried out simultaneously in one bioreactor in a consolidated bio-process (CBP) (3).

There are key cellulolytic enzymes, such as endoglucanases (EGs), cellobiohydrolases (CBHs) and $\beta$-glucosidases (BGLs) that need to be produced from the host microbe in order to efficiently hydrolyse polymeric substrates into fermentable sugars (2). The yeasts Pichia pastoris and Hansenula polymorpha have recently enjoyed more attention as host for expression of recombinant proteins (7). These methylotrophic yeasts have a number of advantages for production of heterologous proteins compared to $S$. cerevisiae, including a high level of protein production $(6,8-10)$. However, these yeasts cannot efficiently produce ethanol from lignocellulosic substrates as their carbon flux favours metabolism and high cell density formation (11). This, in turn, creates high levels of metabolic heat that needs to be removed, as well as a high oxygen demand (11). Therefore, S. cerevisiae remains the first choice for first generation (1G) and second generation (2G) bioethanol production due to its high ethanol yields and ethanol tolerance (12). However, as outlined in the Chapter 2, the fermentation environment in $2 \mathrm{G}$ bioethanol production differs greatly from the classical fermentation set up. The ideal bioethanol producing strain would not only have to display high levels of recombinant cellulase activity, but also be able to tolerate the complex and challenging fermentation medium presented by lignocellulosic hydrolysates (Figure 3.1) (13). Common features of the CBP process include (i) the presence of inhibitory molecules as a result of 
pre-treatment of biomass, and (ii) the inhibitory nature of the desirable products (ethanol) and by-products (13). To overcome these limitations, many researchers are evaluating wild and industrial S. cerevisiae isolates for high tolerance capabilities to hydrolysis products generated in the conversion of lignocellulosic biomass to bioethanol (14-20).

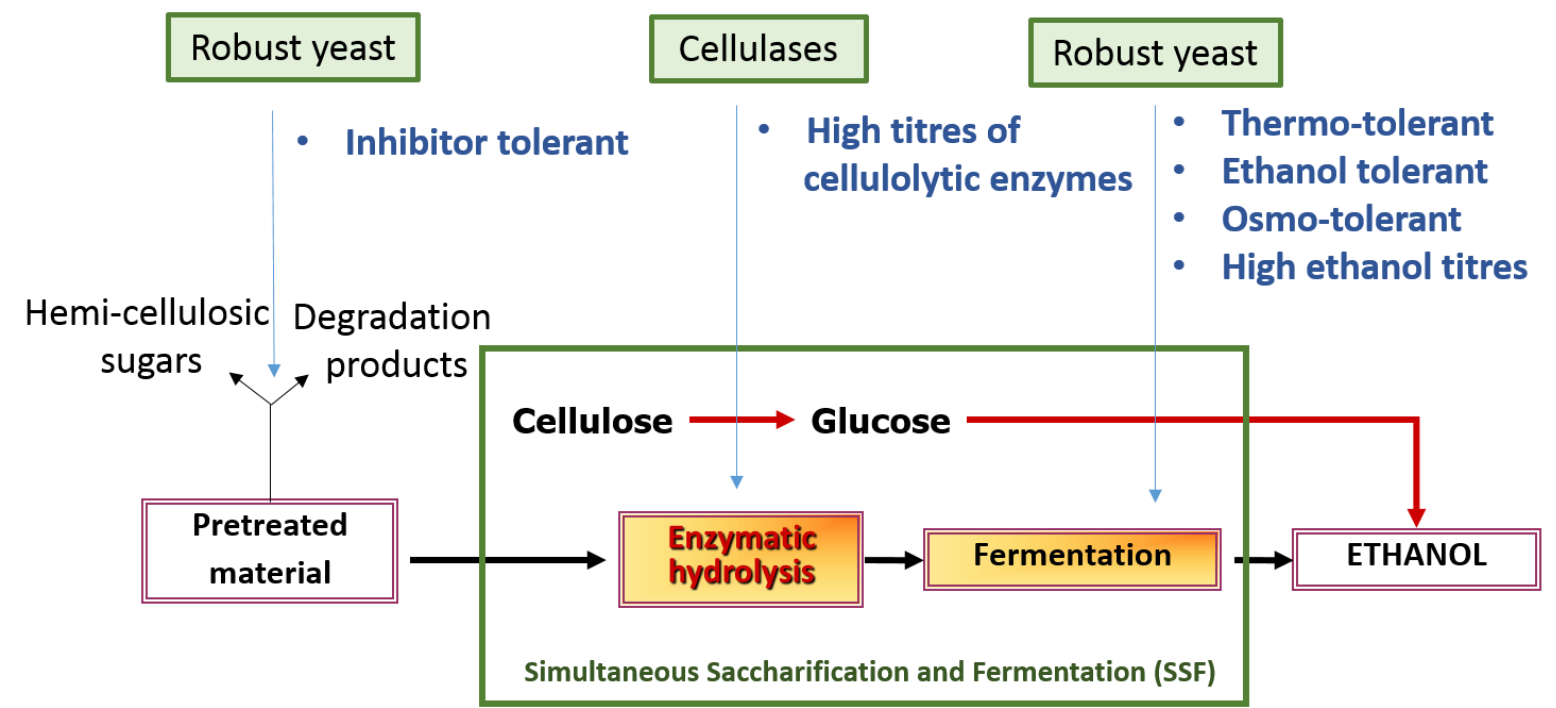

Figure 3.1. Schematic representation of the biological steps and ideal qualities a CBP host strain (text in blue) requires for $2 \mathrm{G}$ cellulosic bioethanol production in an enzyme-based process. During the enzyme hydrolysis (EH) step, the glucose contained in cellulose is liberated by the action of the cellulolytic enzymes (cellulases). The glucose is then converted to ethanol by fermenting microorganisms (bacteria or yeasts). The main advantage of the SSF process is that the continuous removal of the glucose by the microorganism (red arrow), which minimises the end product inhibition of the cellulolytic enzymes, therefore higher EH rates are obtained and better overall yields are reached. Another advantage of this process is that only one fermenter is used resulting in the subsequent reduction in costs.

To date, low to moderate secreted activity levels of cellulolytic enzymes have been found in laboratory and industrial $S$. cerevisiae strains, particularly for BGL and CBH expression $(4,21$, 22). Overproduction and misfolding of heterologous and endogenous proteins can trigger cell stress and cause secretory bottlenecks, increasing metabolic burden, inhibiting growth and hampering secretion yield of heterologous proteins $(7,23-25)$. However, yeasts with diverse genetic backgrounds display variation in secreted heterologous protein titers $(26,27)$, tolerance to inhibitors $(28,29)$, ethanol tolerance $(30)$, growth rates (31), ploidy states (32) and ethanol yields (15). It stands to reason that those same variations would be expected for their cellulase production and secretion capacity and their ability to tolerate endoplasmic reticulum (ER) 
stress. A clear example of the difference in secretion capacity was the significant variation in secreted activity levels of Saccharomycopsis fibuligera Cel3A among seven genetically diverse S. cerevisiae strains, with enzyme activities ranging from $73 \mathrm{mU} / \mathrm{mL}$ to $250 \mathrm{mU} / \mathrm{mL}$ (26). Finding a better recombinant host would not only benefit the energy sector, but also other industries such as the pharmaceutical industries which use yeast to produce insulin, interferons, erythropoietin and several vaccines, such as the human papilloma virus vaccine (7). The prospect of developing $S$. cerevisiae as a CBP organism prompted us to look to natural strains, testing the principle that these strains can be engineered to function as better CBP strains compared to currently used laboratory and industrial strains. No studies, to date, focus on the comparative analysis of enzyme expression patterns among natural strains. Unlike the domesticated strains, natural strains have adapted to overcome a variety of environmental stresses (33). Therefore, natural isolates represent a mostly untapped pool of phenotypic diversity with great potential in biotechnological applications.

In this study, natural strains from a culture collection of environmental isolates of S. cerevisiae were engineered to produce key enzymes in the cellulolytic system and assessed for high innate tolerance to industrial stress factors. To achieve this goal, multiple approaches were used: First, we conducted a comprehensive secretion evaluation of a large collection of natural S. cerevisiae isolates using a multi-copy plasmid containing the $S$. fibuligera cel $3 A$ (S.f.cel3A) gene. In order to serve as a reference, laboratory strains S288c and Y294, and industrial strains MH1000 (industrial distillery yeast; Stellenbosch University, South Africa) and Hoeg (industrial brewing yeast; Stellenbosch University, South Africa) were utilised. Secondly, we individually expressed the Trichoderma reesei cel5A (T.r.cel5A) endoglucanase gene as well as the gene encoding chimeric Talaromyces emersonii Cel7A, a cellobiohydrolase. The T. emersonii Cel7A used in this study contains the catalytic domain from T. emersonii Cel7A, and the linker and carbohydrate binding module (CBM) from T. reesei Cel7A (34). For simplicity, the T. emersonii-T. reesei chimeric Cel7A is generally referred to as T.e.Cel7A and the gene is referred to as T.e.cel7A in the text. The reporter enzymes used in this study were chosen based on their known activity levels and final cellular location. In addition, the transformants were evaluated based on industrially relevant characteristics such as fermentation and tolerance characteristics, ploidy state and growth vigour. The information obtained in this study will be valuable to select strains as platforms for future yeast engineering experiments directed to convert cellulosic substrates to ethanol. 


\subsection{Materials and methods}

\subsubsection{DNA manipulation and yeast transformation}

Standard molecular biology techniques were used for DNA manipulations as described by Sambrook et al. (35). Restriction endonucleases and T4 DNA ligase were purchased from ThermoScientific or New England Biolabs. Digested DNA was extracted from agarose gels with the Zymoclean Gel DNA Recovery Kit from Zymo Research. For polymerase chain reactions (PCR), Phusion DNA polymerase was purchased from ThermoScientific. All kits and enzymes were used as recommended by the manufacturer. Details of primers and constructs used in this study are given in Table 3.1.

Table 3.1. Plasmids and primers used for cellulase gene expression in natural S. cerevisiae strains.

\begin{tabular}{|c|c|c|c|c|}
\hline $\begin{array}{l}\text { Cellulase } \\
\text { gene }\end{array}$ & $\begin{array}{l}\text { Gene } \\
\text { abbrev. }\end{array}$ & $\begin{array}{l}\text { Expression } \\
\text { plasmid }\end{array}$ & $\begin{array}{l}\text { Recombinant } \\
\text { abbrev. }^{\text {d }}\end{array}$ & Primers used for verification $\left(5^{\prime}-3^{\prime}\right)$ \\
\hline S. fibuligera & & pMUSD1 & {$[\mathrm{Cel} 3 \mathrm{~A}]$} & L-GACTCGCGAGTCCCAATTCAAAACTATACC \\
\hline $\operatorname{cel} 3 A^{a}$ & S.f.cel3A & pRDSD1 & _Cel3A & R-CCGCTCGAGCGGTCAAATAGTAAACAGGACAGATG \\
\hline T. reesei & & pMUSD2 & [Cel5A] & L-GTTAACAACAATTTGGGTGG \\
\hline cel5A $A^{b}$ & T.r.cel5A & pRDSD2 & _Cel5A & R-CAATGGAGAAAAAGCACC \\
\hline T. emersonii & T.e.cel7A & pMUSD3 & [Cel7A] & L-GACTTTAATTAAAATGCTAAGAAGAGCTTTACTATTG \\
\hline cel7 $A^{c}$ & & pRDSD3 & _Cel7A & R-GACTGGCGCGCCTTACAAACATTGAGAGTAGTATGGG \\
\hline
\end{tabular}

${ }^{\mathrm{a}}$ T. reesei xyn 2 secretion signal.

${ }^{\mathrm{b}}$ Native secretion signal.

cNative secretion signal, contains the catalytic domain from T. emersonii Cel7A and modified carbohydrate binding module (CBM) from T. reesei Cel7A (34).

dThe brackets [ ] indicates episomal plasmid transformant, whereas the _ indicates delta integrated transformant.

The zeocin resistance marker (sh ble gene) was removed from the episomal plasmid pMU1531 with a BamHI and SpeI restriction digest and replaced by the marker gene encoding for KanMX resistance from plasmid pBKD2 (34), resulting in pMU1531-G418. The DNA sequences containing S.f.cel3A, T.r.cel5A and T.e.cel7A were retrieved from plasmids pMU1531, pRDH147 and pRDH226 (Addendum, Table 1A), respectively, by a restriction digest with PacI and AscI. These fragments were ligated into the corresponding sites of pMU1531-G418 (Addendum, Figure 1Aa) as well as corresponding sites of integration plasmid pBKD2 (Addendum, Figure 1Ab) to yield plasmids pMUSD1/2/3 and pRDSD1/2/3, respectively, with all plasmids containing the selectable marker gene (kanMX) encoding for geneticin (Figure 3.2). With the exception of S.f.cel3A, the expressed genes all preserved the native secretion signals for proteins as previous studies demonstrated that the use of foreign signals can result in misdirection or retention of cellulolytic enzymes in the periplasmic space during secretion $(36,37)$. This was not the case in heterologous production of S.f.Cel3A which has been shown to be secreted well with the $x y n 2$ secretory signal $(36,37)$. 
(a)

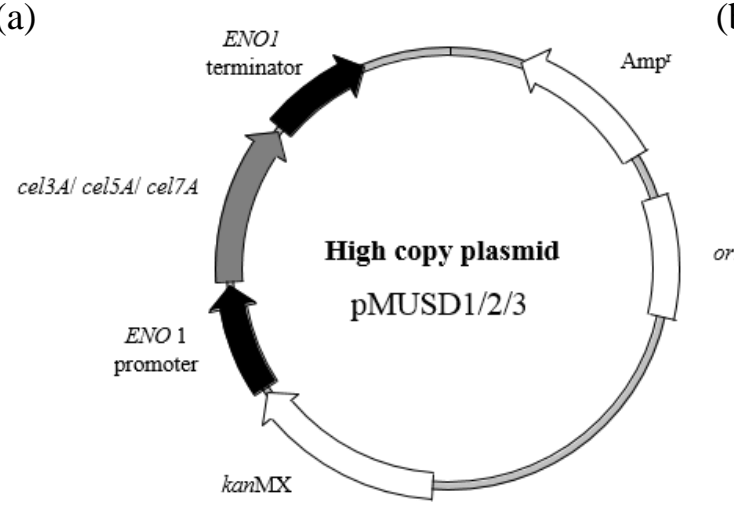

(b)

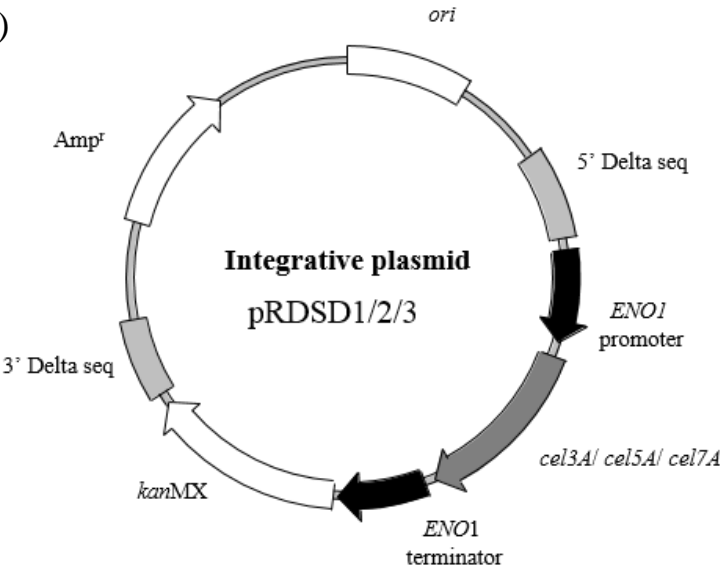

Figure 3.2. Schematic representation of cellulase gene expressing plasmids. (a) Episomal plasmids pMUSD1/2/3 and (b) delta ( $\delta$ )-integration vectors pRDSD1/2/3 were used to screen S.f.Cel3A, T.r.Cel5A and T.e.Cel7A enzyme activity levels, respectively. The genes encoding the cellulases were cloned under the transcriptional control of the strong ENO1 promoter/terminator system and the marker gene kanMX in all cases. The reporter enzymes used in this have been shown to secrete well with the ENO1 promoter/terminator system (36-38).

The episomal plasmids (Figure 3.2a) and integration vectors (Figure 3.2b) were transformed into yeast strains by the electroporation method (35). Integration vectors were linearised with Bst 1107I before transformation. Transformants were selected on $200 \mu \mathrm{g} / \mathrm{mL}$ geneticin (G418) (InvivoGen) - containing plates after an expression step of $3 \mathrm{~h}$ in liquid yeast extract peptone with $2 \%$ glucose (YPD) medium containing $1 \mathrm{M}$ sorbitol. Up to ten colonies from each transformant strain were screened in $5 \mathrm{~mL}$ YPD based on total cell-specific activity, to account for clonal variance. The colony transformants with the highest cell-specific activity of S.f.Cel3A were chosen for triplicate assays. Preliminary screening for high levels of secreted enzyme activity was performed with the reporter protein S.f.Cel3A produced from an episomal plasmid pMUSD1 (Figure 3.2a), before further screening with pMUSD2 and pMUSD3 expressing T.r.cel5A and T.e.cel7A genes, respectively. Delta $(\delta)$ integration was performed using the vectors pRDSD1/2/3 (Figure 3.2b) containing the S.f.cel3A, T.r.cel5A and T.e.cel3A genes, respectively.

The total DNA of the selected transformants were isolated using methods described by Hoffman et al. (39) and the presence of the recombinant cellulase genes in the strains were confirmed by PCR using the primers indicated in Table 3.1. Plate assays confirmed the presence of recombinant activities (Figure 3.4). Extracellular BGL enzyme activity was confirmed using an esculin (esculin 6-O-glucoside) hydrolysis test (42). The secreted $S$.f.Cel3A 
activity produced by different $S$. cerevisiae strains used in this study was observed as dark brown growth on synthetic complete (SC) medium plates $(1.7 \mathrm{~g} / \mathrm{L}$ Bacto-yeast nitrogen base without amino acids [Sigma], $5 \mathrm{~g} / \mathrm{L}$ of ammonium sulphate [Sigma], $20 \mathrm{~g} / \mathrm{L}$ agar [Sigma] and $20 \mathrm{~g} / \mathrm{L}$ glucose) supplemented with $0.1 \%$ esculin and $0.05 \%$ ferric citrate. The active BGLI enzyme cleaves the glycoside group, releasing esculin which reacts with the ferric citrate, resulting in the formation of black zones around the colonies (40). The secreted T.r.Cel5A activities were observed as hydrolysed halos on 1\% CMC agar plates stained for 30 min with $0.1 \%$ Congo Red and de-stained with $1 \mathrm{M} \mathrm{NaCl}$, respectively (38).

\subsubsection{Strains}

The strains utilised in this study were obtained from a culture collection of strains isolated from the various vineyards along the coastal region of the Western Cape, South Africa by the Agricultural Research Council (ARC) Infruitec - Nietvoorbij Wine Research Centre (41) (Table 3.2). Commercial strains MH1000 (industrial distillery yeast, Stellenbosch University) and Hoeg (industrial brewing yeast, Stellenbosch University), and laboratory strains S288c and Y294 (Stellenbosch University) were included in this study as reference stains. The laboratory strains S288c and Y294 are constructed to be diploid, due to the fact that most natural isolates are heterozygous $(41,42)$. Thirty strains were chosen from this culture collection based on fermentation vigour during stressed environments as previously described in unpublished work by Blaauw et al. (43).

\subsubsection{Enzyme activity assays}

Preliminary screening for superior recombinant cellulolytic activity was performed in YPD media with G418 selection by cultivating the yeast strains and determining S.f.Cel3A enzyme activity of total yeast cell cultures and supernatants in liquid assays by use of $p$-nitrophenyl $\beta$-D-glucopyranoside ( $p$ NPG) (Sigma-Aldrich) as previously described (44). The carboxymethyl cellulose (CMC) (Sigma) / 3,5-dinitrosalicylic acid (DNS) method was used to assay EG activity in T.r.Cel5A producing strains, and confirmed with the substrate Cellazyme C (Megazyme) which was used as described by the manufacturer. Methyllumberiferyl $\beta$-D-lactopyranoside (MULac) (Sigma) was used as an assay substrate for Cel7A producing strains $((34,45)$. All volumetric values were normalised with dry cell weight (DCW) of the corresponding yeast cultures in $\mathrm{mg} / \mathrm{mL}$ (46). Enzyme activities were expressed as units/mg DCW, where one unit (U) is defined as the amount of enzyme required to release $1 \mu$ mol of reducing sugar or equivalent per minute. For the $p$ NPG assays, a $p$ NP standard curve in the range of $1.5 \mathrm{mM}-3 \mathrm{mM}$ was used. The range for the DNS standard curve was between 
$0.5 \mathrm{mM}-1.5 \mathrm{mM}$ glucose and the range for the MU standard curve was between $0.63 \mu \mathrm{M}-20$ $\mu \mathrm{M}$. Transformants were initially screened after cultivation in $5 \mathrm{~mL}$ YPD grown for $48 \mathrm{~h}$ on a rotary wheel. Transformants with the highest normalised activity compared to the reference strains were subsequently assayed in triplicate. These transformant strains were cultured in 10 $\mathrm{mL}$ shake flasks with either YPD or double-strength $\mathrm{SC}$ media for $72 \mathrm{~h}$ at $30^{\circ} \mathrm{C}$.

Native invertase activity was measured by adapting the protocol of Troy et al. (46) to act as a comparative reference for secreted enzyme activity levels. Strains were cultured in YP with $2 \%$ galactose for $48 \mathrm{~h}$ after which $10 \mu \mathrm{L}$ of the supernatant was incubated with $70 \mu \mathrm{L} 10 \%$ sucrose for $30 \mathrm{~min}$ at $35^{\circ} \mathrm{C}$. The addition of $120 \mu \mathrm{L} \mathrm{DNS}$ to the mixture and boiling for $5 \mathrm{~min}$ terminated the reaction. Absorbance was measured at $540 \mathrm{~nm}$. The data sets for enzyme activities were tested for statistical significance using the Student's T test and ANOVA, using a $95 \%$ confidence level and $p$-values $<0.05$ were deemed significant. Cell viability and vitality was evaluated using methylene blue exclusion technique (47). Enzymatic assay samples were taken after $72 \mathrm{~h}$ and suitably diluted cell suspension was mixed with an equal volume of methylene blue dye solution for $1 \mathrm{~min}$. The suspension is then mounted on a haemocytometer to count the percentage of live cells in the total population (47). Cells that take up methylene blue are considered dead cells, whereas colourless cells are considered live cells (47).

\subsubsection{Ploidy determination}

The reference strains and seven natural strains, selected based on secretion phenotype and tolerance capabilities, were cultivated in minimal synthetic complete (SC) agar supplemented with $0.1 \mathrm{~g} / \mathrm{L}$ potassium acetate to induce sporulation (48). Protocols for ploidy determination were adapted from published methods (49) and cells were prepared for flow cytometry analysis according to Dumortier et al. (50). Correlated measurements of forward scatter light (FSC) and side scatter light (SSC) allow for differentiation of cell types in a heterogeneous cell population (49). Major subpopulations can be differentiated using FSC and SSC as indicated in Figure 2A (49). A gate is drawn around the population of interest, which in this case is the living cells. A gate or a region is a boundary drawn around a subpopulation to isolate events for analysis or sorting (50). A linear relationship between DNA content and propidium iodide (PI) fluorescence was demonstrated for haploid and diploid transition states of the control haploid S288c and diploid MH1000 cells. DNA histograms were recorded with a FACS Diva Version 6.1.3 flow cytometer. The DNA histograms were analysed with a mathematical model to determine the distribution of cells in the various ploidy classes. 


\subsubsection{Gene copy number}

Real-time quantitative PCR (qPCR) was used to enumerate the kanMX antibiotic selection marker gene that had been used to facilitate the gene integrations and plasmid transformation, allowing us to elucidate the copy numbers of each of the cellulase gene expression cassettes. A single reference gene encoding alpha-1,2-mannosyltransferase ( $A L G 9$ ) was selected to normalise the copy number of our genes of interest, as it is present as a single copy in the haploid complement $S$. cerevisiae genome (51). This method was performed as previously described by Van Zyl et al. (52), using primers listed in the Addendum, Table 1A. These primers are specific to the $A L G 9$ gene present on the yeast genome and the kanMX gene present on gene cassettes and plasmids that were utilised. The qPCR analysis was carried out using the KAPA $^{\mathrm{TM}}$ HRM Fast PCR Kit and the Applied Biosystems StepOne Real-Time PCR System, whilst quantifications of gene copy number were determined using the relative standard curve method (52). The efficiency of amplification for each primer set was determined from a plot of cycle threshold $\left(\mathrm{C}_{\mathrm{t}}\right)$ values of serial dilutions of the template DNA. The efficiency of amplification of the qPCR analysis was based on the slope of the standard curve of the kanMX gene $(98.75 \%)$ and of the $A L G 9$ gene $(108.9 \%)$. The relative copy numbers of the cellulase gene cassettes and plasmids were determined relative to the $A L G 9$ and $k a n M X$ DNA concentrations.

\subsubsection{Growth analysis}

Strains were inoculated in triplicate at a starting optical density $\left(\mathrm{OD}_{600 \mathrm{~nm}}\right)$ of 1 into $20 \mathrm{~mL}$ YP medium supplemented with $2 \%$ glucose, added after autoclaving, in $125 \mathrm{~mL}$ Erlenmeyer flasks. These flasks were incubated on a rotary shaker $(200 \mathrm{rpm})$ at $30^{\circ} \mathrm{C}$ for the duration of the analysis. Samples were diluted (1:20), after which OD $_{600 \mathrm{~nm}}$ readings were taken using Biorad x Mark ${ }^{\mathrm{TM}}$ Microplate Spectrophotometer and the data was adapted to change the microtiter plate readings to $1 \mathrm{~cm}$ light path cuvette readings. Samples were taken every $3 \mathrm{~h}$ for the first $32 \mathrm{~h}$, after which samples were taken at $6 \mathrm{~h}, 9 \mathrm{~h}$ and $10 \mathrm{~h}$, with the final sample taken after $72 \mathrm{~h}$, when growth had ceased or strains had reached stationary phase.

\subsubsection{SDS-PAGE, zymograms and $N$-deglycosylation}

Protein samples were separated by SDS-polyacrylamide gel electrophoresis (SDS-PAGE) (53) and visualised by use of silver staining. To establish cellulase activity for the strains expressing T.e.cel7A and T.r.cel5A genes, a $8 \%$ SDS-PAGE gel with $0.2 \%$ low viscosity CMC (Sigma) was utilised. For the protein gels determining S.f.Cel3A protein bands, a 5\% SDS Page gel was 
utilised. The zymograms were performed as described by Kroukamp et al. (45). To remove protein $N$-linked glycans, $1 \mu \mathrm{L}$ Endoglycosidase H (Endo H) (New England Biolabs) was added into $20 \mu \mathrm{L}$ cell-free culture supernatant and incubated overnight according to the manufacturer's instructions. In control samples, Endo H was replaced by water. To ensure that active enzymes were maintained during the zymogram method, the protocol was adjusted as follows: $1 \mu \mathrm{L}$ deglycosylation buffer was added to $18 \mu \mathrm{L}$ of supernatant sample and incubated at $50^{\circ} \mathrm{C}$ for $10 \mathrm{~min}$. Two microlitres of G5 buffer and $5 \mu \mathrm{L}$ deionised water were then added, followed by $1 \mu \mathrm{L}$ of Endo $\mathrm{H}$ enzyme to the sample to be deglycosylated (indicated by a+ on the gels and zymograms) or $1 \mu \mathrm{L}$ deionised water for the other samples (indicated by a- on the gels and zymograms). The reaction mixes were incubated at $37^{\circ} \mathrm{C}$ for $16 \mathrm{~h}$ after which $7 \mu \mathrm{L}$ of loading buffer was added and $20 \mu \mathrm{L}$ of this mixture was loaded onto the SDS-PAGE gels described above.

\subsubsection{Oxygen-limited fermentation in $2 \%$ glucose YP media}

Fermentations were performed in triplicate in serum bottles containing $100 \mathrm{~mL}$ YPD. Samples were inoculated to an initial $\mathrm{OD}_{600 \mathrm{~nm}}$ of 0.1 and bottles were sealed with a rubber plug to maintain the oxygen-limited conditions. A 0.8 x $25 \mathrm{~mm}$ needle was pierced in each rubber plug to function as $\mathrm{CO}_{2}$ outlet. The serum bottles were incubated on a rotary shaker at $250 \mathrm{rpm}$ for $96 \mathrm{~h}$ at $30^{\circ} \mathrm{C}$. Ethanol, glycerol, acetate and glucose concentrations were quantified with High Performance Liquid Chromatography (HPLC), using a Surveyor Plus Liquid Chromatograph (ThermoScientific) consisting of a LC pump, Autosampler and Refractive Index Detector. The compounds were separated on a Rezex RHM Monosaccharide 7.8 x $300 \mathrm{~mm}$ column (00H0132-K0, Phenomenex) at $80^{\circ} \mathrm{C}$ with $5 \mathrm{mM} \mathrm{H}_{2} \mathrm{SO}_{4}$ as mobile phase at a flow rate of $0.6 \mathrm{~mL} / \mathrm{min}$.

\subsubsection{Co-culture fermentations using Avicel cellulose}

As described in the Section 3.3.1 and 3.3.2, cellulase enzyme secretion yields varied for different YI13 and S288c transformants, specifically, the secreted enzyme activity yield for T.e.Cel7A, T.r.Cel5A and S.f.Cel3A which were approximately $10.0 \mathrm{U} / \mathrm{mg}, 1.75 \mathrm{U} / \mathrm{mg}$ and $0.25 \mathrm{U} / \mathrm{mg}$ DCW for the YI13 transformants and approximately $2.8 \mathrm{U} / \mathrm{mg}, 6.50 \mathrm{U} / \mathrm{mg}$ and $0.78 \mathrm{U} / \mathrm{mg}$ DCW for reference S288c transformants, respectively, based on expression in YPD liquid medium. Such differences in enzyme activity yields were used to design the co-culture experiments for testing the synergy and hydrolysis capabilities of distinct transformants 
utilising Avicel. This type of co-culture experiment was adapted from Wei et al. (54) and Ilmén et al. (34).

Cultures for transformants episomally expressing an empty vector, T.e.cel7A, T.r.cel5A and S.f.cel3A genes were cultivated for $96 \mathrm{~h}$ in $2 \times 250 \mathrm{~mL}$ YPD supplemented with $400 \mu \mathrm{g} / \mathrm{mL}$ G418. The cultures were adjusted to have same $\mathrm{OD}_{600 \mathrm{~nm}}$, then used to prepare cell mixtures by adding the appropriate volumes of cultures to make up $25 \mathrm{~mL}$ of cultures containing $0.5 \mathrm{~g}$ Avicel PH-105 in McCartney bottles, resulting in a final concentration of $20 \mathrm{~g} / \mathrm{L}$. It is noteworthy that targeted cellulase enzyme activity ratios were based on reported optimal ratios of T.e.Cel7A/T.r.Cel7A and T.e.Cel7A/T.r.Cel5A/S.f.Cel3A for efficient hydrolysis of cellulose $(20,58,59)$. For example, 1) for the control, $25 \mathrm{~mL}$ of empty vector transformant cells were added, 2) for binary mixtures, $20.3 \mathrm{~mL}$ of YI13[Cel7A] and $4.7 \mathrm{~mL}$ of YI13 [Cel5A] were added, 3) for tertiary mixtures, $0.59 \mathrm{~mL}$ of YI13[Cel7A], $0.88 \mathrm{~mL}$ of YI13[Cel5A] and $23.52 \mathrm{~mL} \mathrm{YI13[Cel3A]}$ were added and 4) another ternary mixture $0.86 \mathrm{~mL}$ of YI13[Cel7A], $3.45 \mathrm{~mL}$ of YI13[Cel5A] and $20.69 \mathrm{mLYI13[Cel3A]} \mathrm{were} \mathrm{added.} \mathrm{After}$ normalising the above ratios-described as enzyme activity secreted ratios, the expected (target) cellulase enzyme ratio in the secretome of the bi-culture is $8 / 1$ for T.e.Cel7A/T.r.Cel7A proteins, whereas the tri-cultures are $1 / 1 / 1$ and $5 / 2 / 3$, respectively, for the T.e.Cel7A/T.r.Cel5A/S.f.Cel3A proteins. Since BGL is known to be a limiting factor in cellulose hydrolysis, the addition of $100 \mu \mathrm{L}$ of the BGL preparation Novozyme 188 (Sigma) was added for each type of cell mixtures in duplicate bottles. After setup of the cell-mediumAvicel mixtures, the bottles were sealed with a rubber lined caps to maintain the cultures anaerobically and stirred on magnetic stirrers for seven days. Samples were taken on periodically at 0,2, 4 and 7 days and for imaging and HPLC analyses. Cellobiose, glucose, acetic acid, glycerol and ethanol content were determined with HPLC.

\subsubsection{Screening for tolerance to bioethanol-specific stressors}

Yeast strains were cultivated in YPD medium at $30^{\circ} \mathrm{C}$ to an $\mathrm{OD}_{600 \mathrm{~nm}}$ of 0.3 . Ten-fold serial dilutions were spotted onto YPD agar plates containing the appropriate inhibitors, as well as incubated at different temperatures $\left(30^{\circ} \mathrm{C}, 37^{\circ} \mathrm{C}\right.$ and $\left.40^{\circ} \mathrm{C}\right)$, to determine the tolerance capabilities of the strains. Cells were cultivated for $2-3$ days at $30^{\circ} \mathrm{C}$ unless otherwise noted. The inhibitors used in this study include ethanol (7.5\%, 8.0\%, 8.5\%, 9.0\% and 10\% w/v), $\mathrm{NaCl}$ (0.4 M, $0.6 \mathrm{M}, 1 \mathrm{M}$ and $1.2 \mathrm{M})$, tunicamycin $(0.2 \mu \mathrm{g} / \mathrm{mL}, 0.5 \mu \mathrm{g} / \mathrm{mL}, 0.8 \mu \mathrm{g} / \mathrm{mL}$, $1.2 \mu \mathrm{g} / \mathrm{mL}$ and $1.5 \mu \mathrm{g} / \mathrm{mL})$, sodium orthovanadate (0.4 M and $0.5 \mathrm{M})$. 
To evaluate inhibitor tolerance, a five-fold concentrated inhibitor cocktail was prepared as described by Martin et al. (29) containing inhibitors commonly found in spruce (lignocellulosic) hydrolysates. The components in the cocktail include: hydroxymethylfurfural (HMF) (Sigma), cinnamic acid (Sigma) and coniferyl aldehyde (Sigma) dissolved in redistilled water, after which formic acid (Sigma), acetic acid (Sigma) and finally furfural (Sigma) were added, resulting in a $\mathrm{pH}$ range of $2-4$. Concentrations of the individual components of the inhibitor cocktail were chosen based on knowledge of industrial conditions and are detailed in the Addendum, Table 2A. Different concentrations of the cocktail were evaluated $(0 \%, 10 \%$, 25\%, 50\%, 75\% and 100\%). Ten-fold serial dilutions were spotted onto YPD plates supplemented with inhibitors and the viability of each dilution was scored relative to the unchallenged control for each strain. To determine inhibitor resistance, final resistance scores were summed over the three serial dilutions then averaged over replicates and stress doses, providing a score ranging from no growth, initial growth, and medium growth to complete growth for each strain and for each stress factor (Addendum A, Table 3A). The scores were colour coded to create a toelrance map as demonstrated by Kvitek et al. (55).

\subsubsection{Screening for tolerance to secretion and cell wall stresses}

A two-fold serial dilution of yeast cultures (without any episomal plasmid or delta integration), cultivated in YPD until saturated, were spotted onto YPD and SC agar plates containing selected inhibitors including endoplasmic reticulum (ER) stressors (tunicamycin and dithiothreitol), secretion stressor (sodium orthovanadate) and cell wall stressor (Congo Red). Significantly less inhibitor concentrations were required when strains were spotted onto SC agar media compared with the rich YPD agar plates, therefore SC agar plates were utilised for this screening. No variation in strain ranking was observed in the differential media. The mode of action of these inhibitors is discussed in Table $\mathbf{4 A}$ in the Addendum. Strain resistance to tunicamycin (TM) $(0.1 \mu \mathrm{g} / \mathrm{mL}, 0.5 \mu \mathrm{g} / \mathrm{mL}, 0.8 \mu \mathrm{g} / \mathrm{mL}$ and $1.0 \mu \mathrm{g} / \mathrm{mL})$ hygromycin $\mathrm{B}$ (50 $\mu \mathrm{g} / \mathrm{mL}, 100 \mu \mathrm{g} / \mathrm{mL}, 200 \mu \mathrm{g} / \mathrm{mL}$ and $400 \mu \mathrm{g} / \mathrm{mL})$, sodium orthovanadate $(50 \mu \mathrm{g} / \mathrm{mL}, 100$ $\mu \mathrm{g} / \mathrm{mL}, 200 \mu \mathrm{g} / \mathrm{mL}$ and $400 \mu \mathrm{g} / \mathrm{mL})$, dithiothreitol (DTT) $(10 \mathrm{mM}, 20 \mathrm{mM}, 30 \mathrm{mM}, 40 \mathrm{mM}$ and $50 \mathrm{mM})$ and Congo Red $(50 \mu \mathrm{g} / \mathrm{mL}, 100 \mu \mathrm{g} / \mathrm{mL}, 200 \mu \mathrm{g} / \mathrm{mL}$ and $400 \mu \mathrm{g} / \mathrm{mL})$ were evaluated. 


\subsection{Results and discussion}

\subsubsection{Preliminary screening for superior $S$.f. Cel3A activity from natural transformants}

In previous work by Van der Westhuizen et al. (41), natural S. cerevisiae strains were isolated from vineyards along the winery, coastal regions of the Western Cape, South Africa (Table 3.2). Thirty natural strains were selected from this culture collection based on fermentative vigour in stressed conditions as reported in unpublished work by Blauuw et al. (46). Industrial, benchmark strains MH1000 (distillery yeast, Stellenbosch University, South Africa) and Hoeg (brewing yeast, Stellenbosch University, South Africa), and laboratory stains S288c and Y294 (Stellenbosch University, South Africa) $(56,57)$ were included in this study for comparison of relatively diverse backgrounds and to act as reference strains. Low secreted activity of BGL by $S$. cerevisiae has often been reported $(26,37,58)$, however, this enzyme represents a ratelimiting step in saccharification of cellobiose as the enzyme converts cellobiose into fermentable glucose (2). For this reason, the constitutive expression of S.f.cel3A on an episomal plasmid was used as a reporter enzyme to screen for more favourable production and secretion of heterologous BGLI activity. First, the sensitivities of the strains to several drugs commonly used for genetic manipulation of industrial strains were assessed. Strains are sensitive to 400 $\mu \mathrm{g} / \mathrm{mL} \mathrm{G} 418$ and above $600 \mu \mathrm{g} / \mathrm{mL}$ for zeocin and hygromycin (data not shown). Therefore, the most effective marker to use in this study was determined to be kanMX gene. 
Table 3.2. Cell-specific total, secreted and percentage released of S.f.Cel3A activity obtained from the S. cerevisiae transformants generated in this work.

\begin{tabular}{|c|c|c|c|c|}
\hline \multirow[b]{2}{*}{ Ranking $^{\mathrm{a}}$} & \multirow[b]{2}{*}{ Host strain ${ }^{\mathrm{b}}$} & \multicolumn{3}{|c|}{ S.f.Cel3A activity ${ }^{\mathrm{cd}}$ (U/mg DCW) } \\
\hline & & Supernatant activity & $\begin{array}{l}\text { Total cell } \\
\text { activity }\end{array}$ & $\begin{array}{c}\text { \% Released into } \\
\text { media }^{\mathrm{e}}\end{array}$ \\
\hline 1 & FIN1 & $\$ 2.54 \pm 1.38$ & $7.07 \pm 2.49$ & $36 \pm 0.09$ \\
\hline 2 & MF15 & $\dagger 1.22 \pm 0.57$ & $2.12 \pm 0.96$ & $58 \pm 0.09$ \\
\hline 3 & YI19 & ${ }^{\dagger} 1.19 \pm 0.24$ & $1.72 \pm 1.45$ & $70 \pm 0.11$ \\
\hline 4 & YI27 & $1.05 \pm 0.81$ & $2.18 \pm 1.46$ & $48 \pm 0.01$ \\
\hline 5 & HR4 & ${ }^{\dagger} 0.90 \pm 0.26$ & $0.86 \pm 0.81$ & $46 \pm 0.00$ \\
\hline 6 & YI59 & $\dagger^{\dagger} 0.88 \pm 0.15$ & $1.89 \pm 1.32$ & $46 \pm 0.04$ \\
\hline 7 & W21 & $0.87 \pm 0.28$ & $1.45 \pm 1.07$ & $60 \pm 0.08$ \\
\hline 8 & YI9 & $\dagger 0.74 \pm 0.39$ & $1.38 \pm 1.06$ & $54 \pm 0.06$ \\
\hline 9 & MF1 & $0.59 \pm 0.16$ & $1.75 \pm 1.24$ & $34 \pm 0.68$ \\
\hline 10 & YI14 & $0.56 \pm 0.17$ & $2.09 \pm 1.38$ & $27 \pm 0.15$ \\
\hline 11 & B25 & $0.53 \pm 0.25$ & $1.24 \pm 0.70$ & $43 \pm 0.08$ \\
\hline 12 & C11 & $0.50 \pm 0.09$ & $3.93 \pm 1.72$ & $13 \pm 0.15$ \\
\hline 13 & YI64 & $0.44 \pm 0.08$ & $1.04 \pm 0.92$ & $42 \pm 0.13$ \\
\hline 14 & YI2 & $0.32 \pm 0.23$ & $1.17 \pm 0.90$ & $27 \pm 0.13$ \\
\hline 15 & W13 & $0.31 \pm 0.09$ & $1.11 \pm 0.84$ & $28 \pm 0.11$ \\
\hline 16 & YI57 & $\dagger 0.30 \pm 0.04$ & $1.08 \pm 0.73$ & $28 \pm 0.10$ \\
\hline 17 & YI13 & $0.27 \pm 0.10$ & $2.01 \pm 1.45$ & $14 \pm 0.14$ \\
\hline 18 & YI52 & $0.26 \pm 0.13$ & $1.84 \pm 1.47$ & $14 \pm 0.14$ \\
\hline 19 & YI38 & $0.25 \pm 0.05$ & $2.52 \pm 1.26$ & $10 \pm 0.28$ \\
\hline 20 & W12 & $0.24 \pm 0.05$ & $2.21 \pm 1.33$ & $11 \pm 0.28$ \\
\hline 21 & W24 & $0.23 \pm 0.04$ & $1.79 \pm 1.41$ & $13 \pm 0.27$ \\
\hline 22 & Y11 & $0.20 \pm 0.07$ & $1.50 \pm 1.15$ & $13 \pm 0.42$ \\
\hline 23 & V3 & $0.20 \pm 0.14$ & $1.33 \pm 1.04$ & $15 \pm 0.13$ \\
\hline 24 & F11 & $0.18 \pm 0.25$ & $2.25 \pm 1.04$ & $08 \pm 0.43$ \\
\hline 25 & YI46 & $0.18 \pm 0.31$ & $1.18 \pm 0.98$ & $15 \pm 0.27$ \\
\hline 26 & W5 & $0.18 \pm 0.14$ & $0.26 \pm 0.60$ & $68 \pm 0.34$ \\
\hline 27 & YI56 & $0.13 \pm 0.17$ & $2.08 \pm 1.77$ & $06 \pm 0.54$ \\
\hline 28 & $\mathrm{~W} 1$ & $0.11 \pm 0.04$ & $1.43 \pm 1.23$ & $08 \pm 0.60$ \\
\hline 29 & YI40 & $0.04 \pm 0.18$ & $1.16 \pm 0.95$ & $04 \pm 0.46$ \\
\hline 30 & YI32 & $0.01 \pm 0.33$ & $4.99 \pm 2.87$ & $00 \pm 0.46$ \\
\hline Ref. & Hoeg $^{f}$ & $0.61 \pm 0.05$ & $0.67 \pm 0.92$ & $09 \pm 0.48$ \\
\hline Ref. & MH1000g & $0.01 \pm 0.21$ & $1.05 \pm 0.91$ & $01 \pm 0.70$ \\
\hline Ref. & Y294 & $0.42 \pm 0.22$ & $1.83 \pm 0.21$ & $09 \pm 0.58$ \\
\hline Ref. & $\mathrm{S} 288 \mathrm{c}^{\mathrm{i}}$ & $0.12 \pm 0.05$ & $1.15 \pm 0.95$ & $11 \pm 0.36$ \\
\hline
\end{tabular}

${ }^{a}$ Enzyme ranking according to supernatant activity level.

${ }^{\mathrm{b}}$ Strains are from microbial collection of S. cerevisiae (Microbiology Department, Stellenbosch University, South Africa).

${ }^{\mathrm{c}}$ Standard deviation of triplicates is indicated with \pm .

${ }^{\mathrm{d}} S . f$.Cel3A activities significantly higher than the reference strain $\mathrm{S} 288 \mathrm{c}$ are indicated with $\dagger(95 \%$ confidence $)$ and $+(99 \%$ confidence $)$.

${ }^{\mathrm{e}}$ Percentage of the supernatant $S . f$.Cel3A activity measured in the cell fraction.

${ }^{\mathrm{f}}$ Reference industrial strain (commercial brewing yeast, Stellenbosch University, South Africa).

${ }^{\mathrm{g}}$ Reference commercial strain (industrial distillery yeast, Stellenbosch University, South Africa) (28).

${ }^{\mathrm{h}}$ Reference laboratory strain (ATCC 201160).

${ }^{\mathrm{i}}$ Reference laboratory strain $(56,57)$. 
After transforming the thirty natural strains with episomal plasmid pMUSD1, ten different colonies obtained from each transformation were inoculated into $5 \mathrm{~mL}$ YPD with $400 \mu \mathrm{g} / \mathrm{mL}$ G418 and tested for S.f.Cel3A activity. It was observed that there is expression variance between transformants of the same strain, likely due to clonal variance. Therefore, three transformants with the highest enzyme activity per gram dry cell weight (DCW) were selected for further study. Cell-specific enzyme activity was analysed in both culture medium and in the total cell fraction (Table 3.2). Prior to enzyme assays, untransformed strains are confirmed to have no or negligible natural S.f.Cel3A activity (Figure 3.3c). A clear variation in secreted enzyme cell specific activity of S.f.Cel3A was evident between the natural strains ranging between 0.00-2.54 U/mg DCW (Figure 3.3a), even though the same regulatory sequence (ENO1 promoter and terminator) and the same vector backbone (pMUSD1) was used. It was noted that the reference strains S288c and MH1000 produced levels of extracellular S.f.Cel3A activity that confirmed poor secretion levels previously observed in prior studies $(26,37,59)$ To ensure that the low levels of enzymatic activity observed in S288c was not an anomaly particular to that strain, activity from episomal expression of S.f.cel3A, T.r.cel5A and T.e.cel7A genes was examined in two further $S$. cerevisiae reference strains namely; laboratory Y294 (ATCC 201160) $(56,57)$ and brewing strain Hoeg (distillery yeast, Stellenbosch University, South Africa). These strains were found to have similar enzyme activity levels to the S288c and MH1000 based on the results seen in Table 3.2.

Based on enzyme activity ranking of all the strains, the FIN1[Cel3A] strain had the highest total cell (7.07 U/mg DCW) and extracellular (2.54 U/mg DCW) activity (Figure 3.3a \& b). The extracellular enzyme activity was 21-fold higher than that of the reference strain S288c ( $p$ value 0.005) (Figure 3.3a). From Figure 3.3b, YI32 also demonstrated high total cell S.f.Cel3A activity (4.99 U/mg DCW). This suggests that naturally occurring strains of S. cerevisiae could be potential CBP strains with higher secreted cell specific activity levels of S.f.Cel3A than currently used commercial strains. The superior activity levels observed from the natural strains provide a preliminary platform to identifying strains with a high general secretion phenotype. This preliminary screening with the episomal S.f.cel3A gene expression allowed us to select four superior strains (FIN1, MF15, and YI19 and YI59) with promising secretion phenotypes, to act as host strains for further cellulase activity studies. A further three strains with moderate secreted enzyme activity levels (V3, YI1 and YI13) were included based on their high ethanol tolerance performance (Addendum, Figure 4A). 
(a)

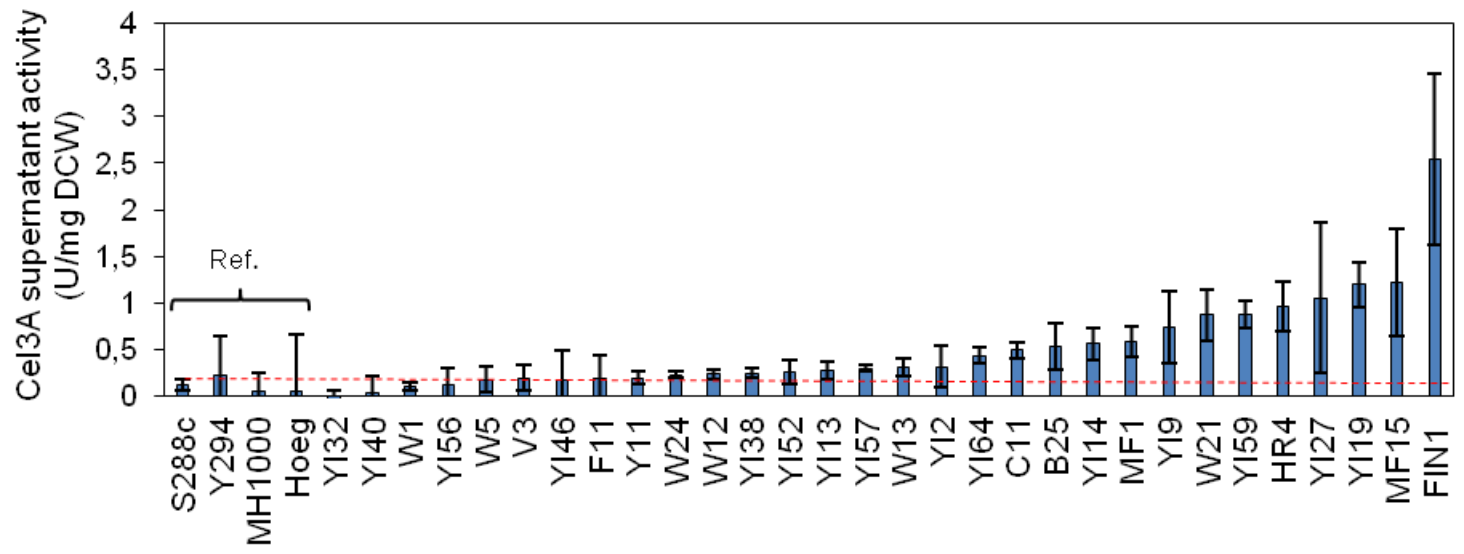

(b)

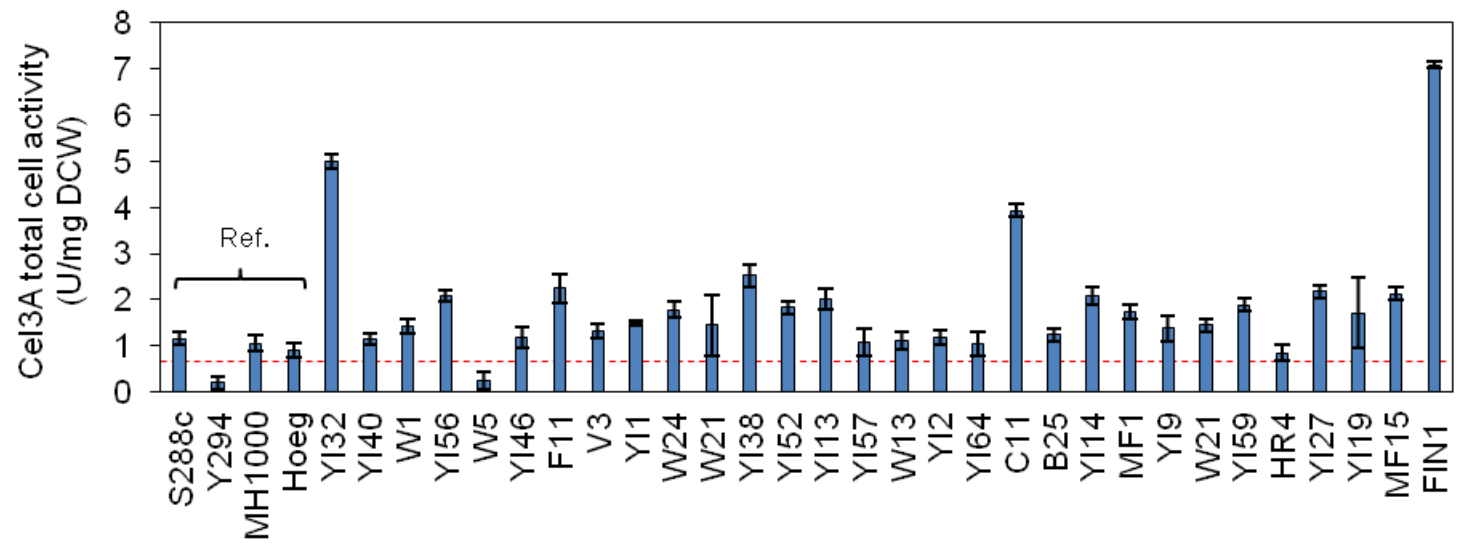

(c)

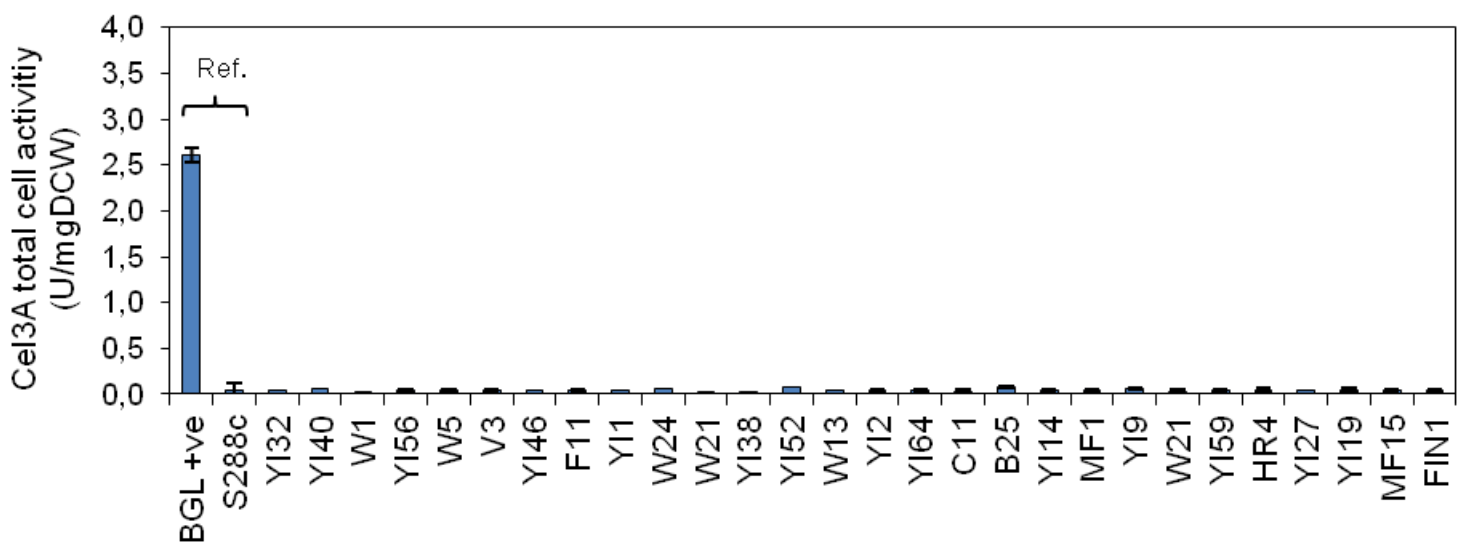

Figure 3.3. Heterologous (a) supernatant and (b) total cell-specific S.f.Cel3A (BGL1) activities ranked based on supernatant enzyme ranking of natural strains in comparison to the reference strains (indicated as Ref. on graph) after $72 \mathrm{~h}$ expression in YPD. Values obtained were normalised with the dry cell weight (DCW). (c) Wild-type strains are confirmed to have negligible Cel3A activity. Error bars indicate standard deviation from the mean value obtained from three biological repeats. The dotted lines shown in (a) and (b) represents the average activity of the four reference strains. A positive control strain containing pMUSD1 (named BGL +ve) was used as reference the graph (c).

Confirming the results of Gurgu et al. (26), we demonstrated that the strains vary in degree of S.f.Cel3A association to the cell, ranging in $0.1 \%-70 \%$ of the enzyme being freely secreted into the extracellular media (Table 3.2). More than half the strains released less than $30 \%$ of 
S.f.Cel3A activity into the supernatant, suggesting that this enzyme is highly cell-associated, especially in reference strains. For example, the high S.f.Cel3A-producing strain FIN1 was noted to only release $36 \%$ of the total S.f.Cel3A cell specific activity into the supernatant, while the reference strains released only $0.1-11 \%$ of the enzyme into the culture media. As suggested by previous studies, this confirms that $S . f$.Cel3A is largely a cell associated enzyme $(26,37$, 60), even with a strong secretion signal present. It has been shown that the putative carbohydrate recognition domain of the Cel3A may be influenced by cell wall composition (60). Saccharomyces cerevisiae does not effectively secrete proteins with a molecular mass exceeding $30 \mathrm{kDa}$, presumably because of the physical barrier presented by the yeast cell wall $(36,60)$. Therefore, the recombinant S.f.Cel3A enzyme produced by $S$. cerevisiae is successfully directed through the secretion pathway with the aid of the xyn 2 secretion signal, but may be held back in the periplasmic space by the cell wall matrix due to its size $(120 \mathrm{kDa})$ (36). Further research is needed to look at the cell wall structure in the superior strain FIN1 in comparison to reference strains.

\subsubsection{Recombinant T.r.cel5A and T.e.cel7A activity of selected natural strains}

The cellulase genes S.f.cel3A, T.r.cel5A and T.e.cel7A were chosen to be individually expressed through episomal plasmids and $\delta$-integration into the selected four superior and three moderate natural strains. Previous studies have indicated that co-expression of recombinant cellulase genes often leads to reduced activities of one or both of the enzymes $(38,43)$. The production of S.f.Cel3A, T.r.Cel5A and T.e.Cel7A enzymes were chosen as reporter proteins in order to evaluate secreted activity levels based on previous data relating to their known enzymatic activity and final cellular location $(38,39,43)$. Transformants were confirmed to have cellulase activity based on plate assays (Figure 3.4). The wild-type strains did not show any growth or hydrolysis activity on the substrates, therefore no cellulase activity was detected. Cell lysis and subsequent leakage is known to be a contributing factor to higher enzyme activity in the culture supernatant, therefore methylene blue dye exclusion technique (50) was used to differentiate between live and dead (lysed) cells during the enzyme assays. Cell count measurements indicated that the percentage of dead cells is minimal (the amount of live cells was on average 97\% after $72 \mathrm{~h}$ cultivation) (Addendum, Figure 5A). To serve as a good comparative reference and internal control for secreted activity levels, endogenous invertase activity was measured because it is expressed from a single copy gene in the strains (64). 
(a) S.f.Cel3A

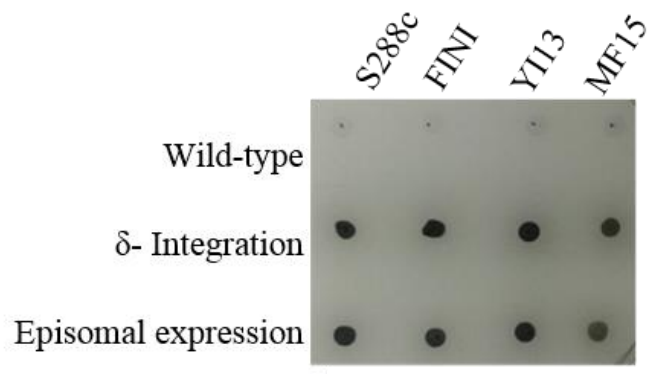

(b) T.r.Cel5A

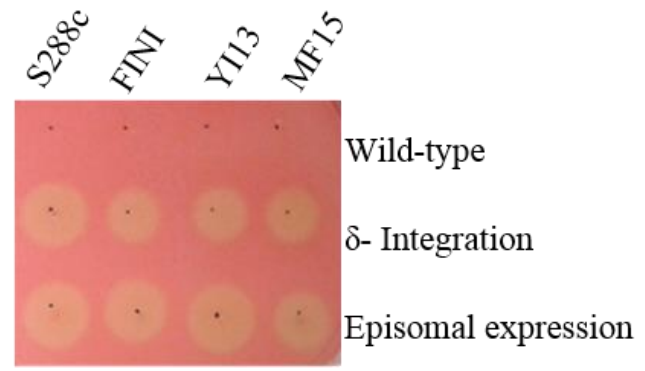

Figure 3.4. Spot test assays for the detection of (a) S.f.Cel3A and (b) T.r.Cel5A activities of S. cerevisiae transformants. Supernatant cultures were spotted onto SC agar plates supplemented with either esculin and ferric citrate, or CMC for $48 \mathrm{~h}$ and $24 \mathrm{~h}$, respectively. The wild-types did not show any extracellular S.f.Cel3A and T.r.Cel5A activity.

In the liquid assays, the FIN1[Cel3A] demonstrated a significantly higher S.f.Cel3A supernatant activity level ( $p$-value 0.0029) compared to the reference strain S288c (Figure 3.5a), despite having low production and secreted activity levels for T.r.Cel5A and T.e.Cel7A, respectively (Figure 3.5b \& c). The YI13 transformants expressing the genes T.e.cel7A and T.r.cel5A from individual episomal plasmids demonstrated the highest cell specific supernatant activity for T.e.Cel7A (9.99 U/mg DCW) and T.r.Cel5A (6.50 U/mg DCW), respectively, compared to the rest of the transformants (Figure 3.5a \& b). A 3.7-fold ( $p$-value 0.041) and 3.5-fold ( $p$-value 0.0296) higher T.e.Cel7A and T.r.Cel5A supernatant enzyme activity, respectively, was observed in the YI13 strain compared to the reference strain S288c, however this strain produced low levels of S.f.Cel3A activity. The secreted invertase activity was 2.6-fold higher in natural strain YI13 (2.4 U/mg DCW) compared to the reference strain S288c (0.9 U/mg DCW). As observed in Figure 3.5d, YI59 strain was noted to have highest secreted invertase activity (3.06 U/mg DCW), despite displaying moderate to low secreted cellulase activity levels. This confirms that variation in secreted invertase activity levels is largely strain-specific.

It would appear that differential cellulolytic activity levels may not only be dependent on the genetic background of the host alone, but may also be distinctly protein-specific as observed by Idiris et al. (7); Kroukamp et al. (61) and Van Zyl et al. (52). A compatibility factor in terms of hosts and cellulase activity may explain why specific cellulolytic enzymes are more compatible to high levels of production and secretion in one host compared with another. Differential enzyme activity most likely results from differences in post-translational processing, ploidy states, gene copy number, protein stability and/or export as suggested by 
Kroukamp et al. (61) and Idiris et al. (7).

(a)

(b)

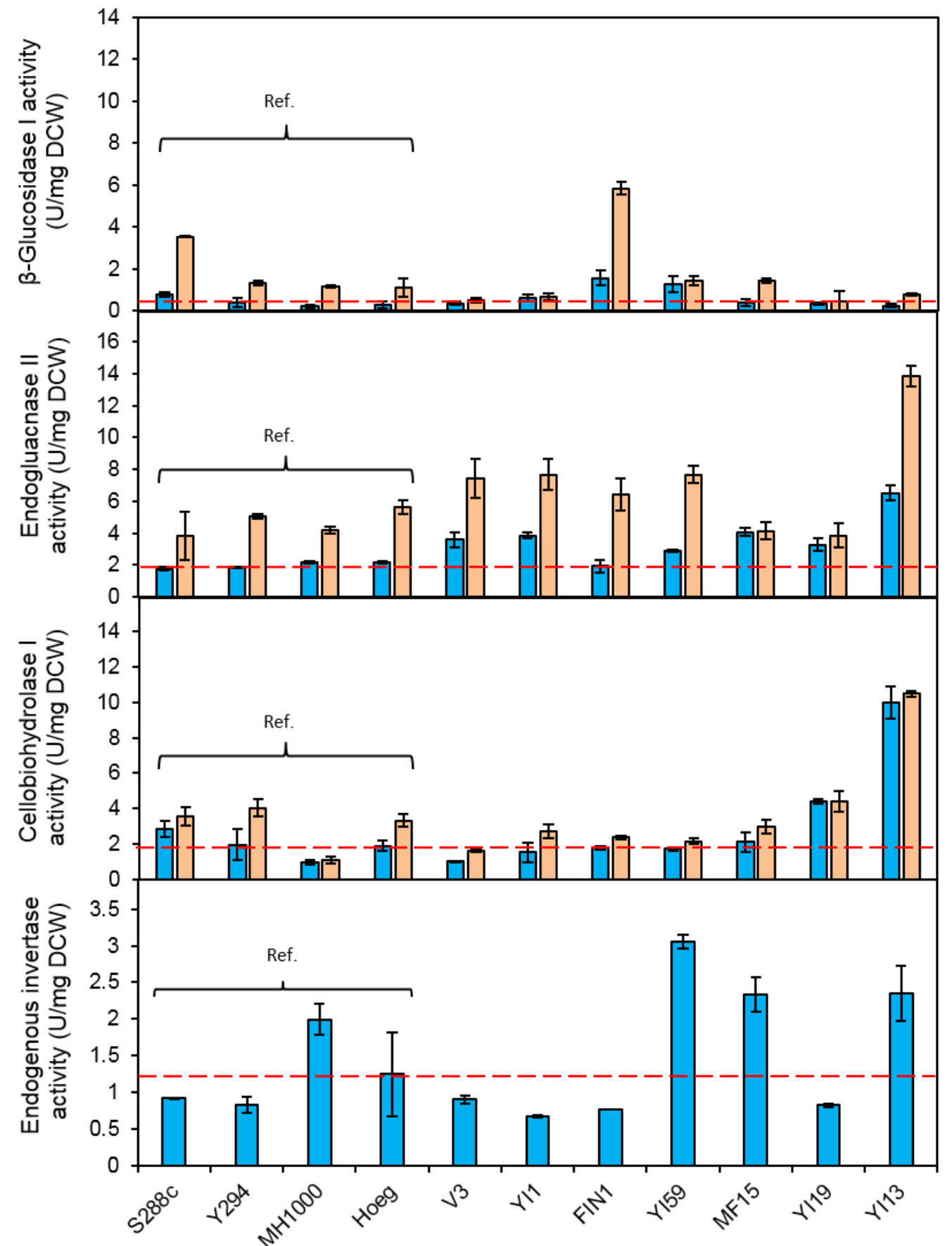

Figure 3.5. Comparison between extracellular (blue bars) and total cell (orange bars) (a) S.f.Cel3A (b) T.r.Cel5A and (c) T.e.Cel7A cell-specific activities of S. cerevisiae episomal transformants. (d) Extracellular endogenous invertase activities were also evaluated. The error bars represent standard deviations from the mean. Values obtained were normalised with the dry cell weight (DCW) of the yeast after $72 \mathrm{~h}$ incubation. Wild-type strains demonstrated negligible activity on all substrates assayed (data not shown). The dotted line shown in (a)-(d) represents the average extracelluar activity levels of the four reference strains. Reference strains are indicated as Ref. on the graphs. 
In order to elucidate the influence of gene copy number in heterologous expression, the $\delta$-integration technique was used as it generally yields lower copy numbers than episomal plasmids (62). This allowed us to generate transformants with low gene copy numbers to evaluate enzyme activity differences between superior natural strains (FIN1, YI13 and MF15) and reference strain S288c (Figure 3.6).

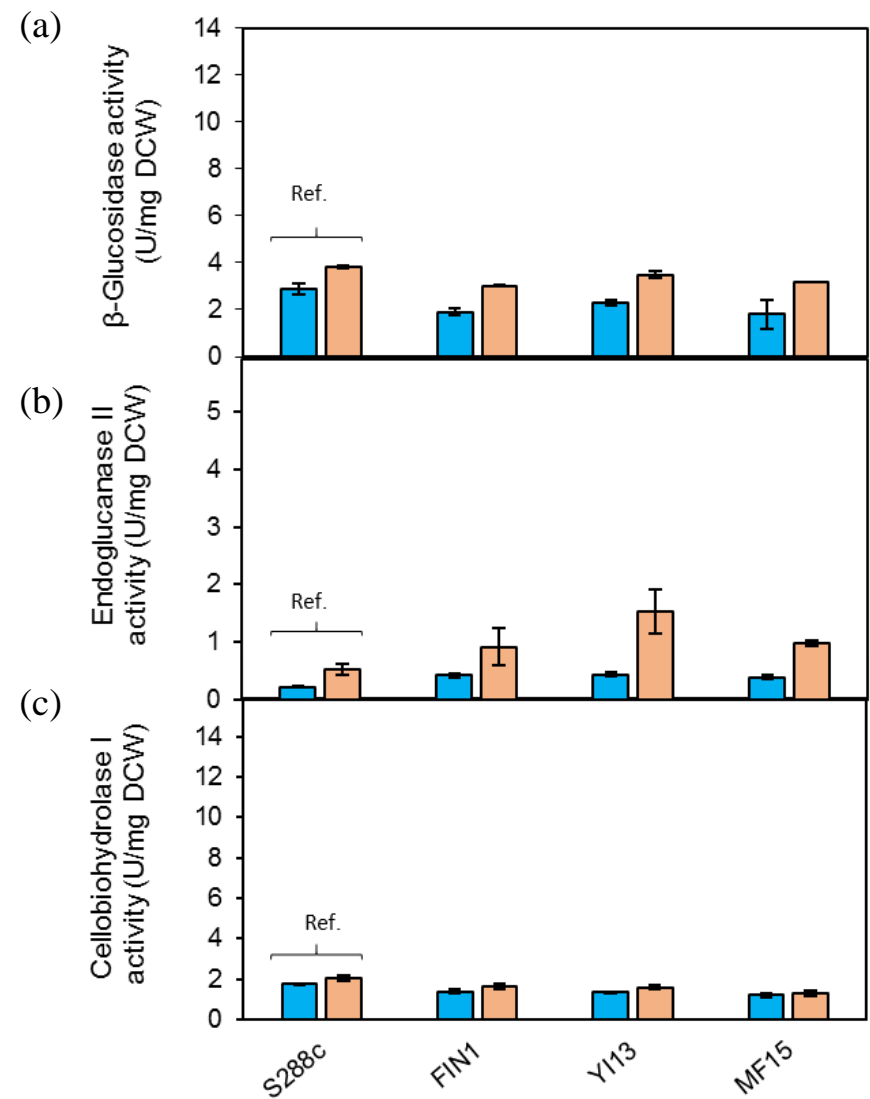

Figure 3.6. Comparison between total cell (orange bars) and extracellular (blue bars) (a) S.f.Cel3A (b) T.r.Cel5A and (c) T.e.Cel7A activity levels of $\delta$-integrated transformants. Strains are compared to the reference laboratory strain S288c (indicated as Ref. on the graphs). The error bars represent standard deviations from the mean.

While no discernible difference in secreted cellulolytic activity level was observed amongst the integrated transformants compared to the reference strain S288c (Figure 3.6a, b \& c c), there was variation in total cell T.r.Cel5A activity obtained by the YI13 natural isolate (Figure 3.6b). The YI13 transformant integrated with the T.r.cel5A gene displayed the highest total cell activity of $1.53 \mathrm{U} / \mathrm{mg}$ DCW compared to the rest of the strains. The levels of enzymes produced by a specific strain are suggested to be dependent on gene copy number as significantly $(p<0.05)$ more activity was detected from cells containing the plasmids than the integrated strains (Figure 3.5 \& 3.6). Therefore, the observed differential activity may have resulted from differences in the levels at which plasmids were maintained between reference strains and 
natural strains.

\subsubsection{Plasmid and integrated gene copy numbers}

The influence of copy number of gene targets and expression levels have been investigated previously (63), and while some studies indicate that increasing gene copy numbers can increase some enzymatic activity, this is not true for all enzymes (64). Results have suggested that higher number of target genes are effective for improving cellulolytic activity, however, it is not proportionate (65). In order to evaluate gene copy number differences between reference and superior natural transformants, episomal plasmids and $\delta$-integration vectors were employed to generate transformants with various gene copy numbers. Two independent quantification methods (using $A L G 9$ and kanMX genes) and using real-time PCR (qPCR) analysis confirmed that the $\delta$-integrated transformants had only one to two gene copies of the cellulase gene correlating to the enzyme activity levels (Table 3.3).

Table 3.3. The quantification of heterologous S.f.cel3A, T.r.cel5A and T.e.cel7A genes expressed episomally or integrated into the genome of reference strain S288c and natural strains FIN1, YI13 and MF15.

\begin{tabular}{rllll}
\hline \multirow{2}{*}{ Strains $^{\mathrm{c}}$} & \multicolumn{4}{l}{ Relative copy number } \\
\cline { 2 - 5 } & S288c & FIN1 & YI13 & MF15 \\
\hline Episomal plasmids & & & & \\
[Cel3A] & $5.16 \pm 0.16(5)$ & $4.11 \pm 0.19(4)$ & $4.19 \pm 0.03(4)$ & $4.00 \pm 0.12(4)$ \\
[Cel5A] & $3.89 \pm 0.20(4)$ & $4.18 \pm 0.07(4)$ & $3.03 \pm 0.24(3)$ & $3.07 \pm 0.78(3)$ \\
[Cel7A] & $4.26 \pm 0.07(4)$ & $3.02 \pm 0.03(3)$ & $3.74 \pm 0.03(4)$ & $3.29 \pm 0.13(3)$ \\
$\delta$-Integrated genes & & & & \\
_Cel3A & $0.97 \pm 0.19(1)$ & $0.98 \pm 0.1(1)$ & $0.71 \pm 0.1(1)$ & $0.95 \pm 0.34(1)$ \\
_Cel5A & $0.59 \pm 0.46(1)$ & $0.77 \pm 0.28(1)$ & $0.85 \pm 1.53(1)$ & $0.98 \pm 0.97(1)$ \\
_Cel7A & $1.85 \pm 0.64(2)$ & $1.66 \pm 0.59(2)$ & $0.72 \pm 1.16(1)$ & $1.53 \pm 0.51(2)$ \\
\hline
\end{tabular}

${ }^{\text {a }}$ Standard deviation of triplicates is indicated with \pm .

${ }^{\mathrm{b}}$ Rounded numbers are indicated in brackets.

Low variation in episomal plasmid copy numbers between episomal transformants was confirmed. No more than a 1.7-fold difference in the copy number of the episomal plasmids was observed (Table 3.3), therefore this parameter alone could not account for the observed significant differences in the secreted cell specific enzyme activities between the reference transformant S288c and natural strains YI13 and FIN1 expressing episomal plasmids. However, to account for variation in copy number, cellulolytic enzyme activity levels were normalised relative to plasmid copy number (Figure 3.7). After normalising with plasmid copy number, no change in enzyme rankings of the strains could be observed (Figure 3.5 compared to Figure 3.7). From Figure 3.7, it was observed that the YI13 transformants continued to have 
the highest activity for T.r.Cel5A and T.e.Cel7A after normalisation with plasmid copy number. Furthermore, this natural strain demonstrated a 4.7-fold and 7.6-fold higher supernatant activity per copy number of T.r.Cel5A and T.e.Cel7A, respectively, compared to the reference strain S288c. The superior FIN1 transformant continued to have the highest $S . f$.Cel3A activities (2.5-fold higher supernatant activity per copy number), but relatively low T.r.Cel5A and T.e.Cel7A activities compared to the rest of the strains.

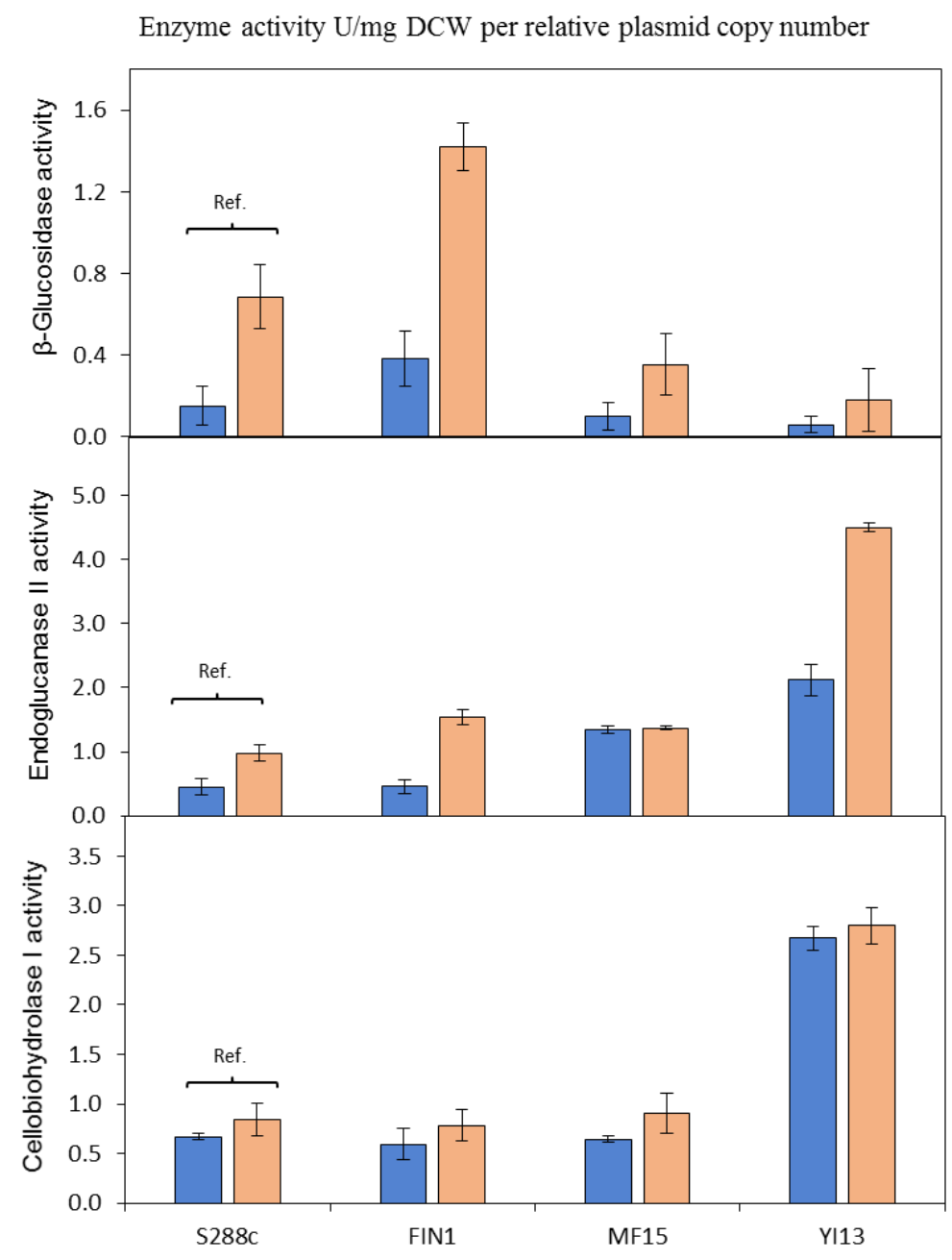

Figure 3.7. Supernatant (orange bars) and total (blue bars) recombinant cellulolytic activities normalised per relative plasmid copy number as determined by quantitative PCR. Transformants are ranked against the reference strain S288c expressing (a) T.r.cel5A, (b) T.e.cel7A and (c) S.f.cel3A genes from episomal plasmids. Each enzymatic assay and PCR was performed in triplicate. The error bars represent standard deviations from the mean from three biological repeats. The reference strain S288c is indicated as Ref. on the graphs. 


\subsubsection{Transformant stability and ploidy determination of natural strains.}

Keeping characteristics obtained by molecular modification stable is an important consideration for industrial use of yeast strains (66). The integration of genes into the yeast chromosomes eliminates segregational instability related to plasmid vectors and offers a more stable alternative for the maintenance of heterologous proteins (67). Since genomic instability varies greatly between strains $(66,68)$, it is important to determine the stability of the transformants.

In order to investigate transformant stability between integrative transformants, the empty control integration vector pBKD2 (Addendum, Figure 1A) was used to express the kanMX gene (conferring geneticin resistance) in superior strains YI13 and FIN1, as well as moderate secreting strain MF15 and the reference strain S288c. Yeast transformants were cultivated at $30^{\circ} \mathrm{C}$ in $5 \mathrm{~mL}$ rich non-selective media and re-inoculated in fresh media every $48 \mathrm{~h}$. For selection of G418-harbouring transformants, media was supplemented $400 \mu \mathrm{g} / \mathrm{mL} \mathrm{G418.} \mathrm{To}$ measure the fraction of G418-containing cells, diluted samples $\left(\times 10^{-4}\right)$ were spread on a non-selective plate and replica plated onto selective YP agar plates. The plates were incubated at $30^{\circ} \mathrm{C}$ for $48 \mathrm{~h}$. The ratio of the number of CFUs (colony forming units) on the selective agar plate was compared to that on the non-selective agar plates and taken as the fraction of G418-containing cells (\% G418-containing cells) (Figure 3.8). The aim of this experiment was to examine whether the stability characteristics of the integration of gene cassettes by pBKD2 vary between the $S$. cerevisiae strains. Based on the results from Figure 3.8, we can confirm the $\delta$-integration gene cassettes were stably integrated into all the transformants.

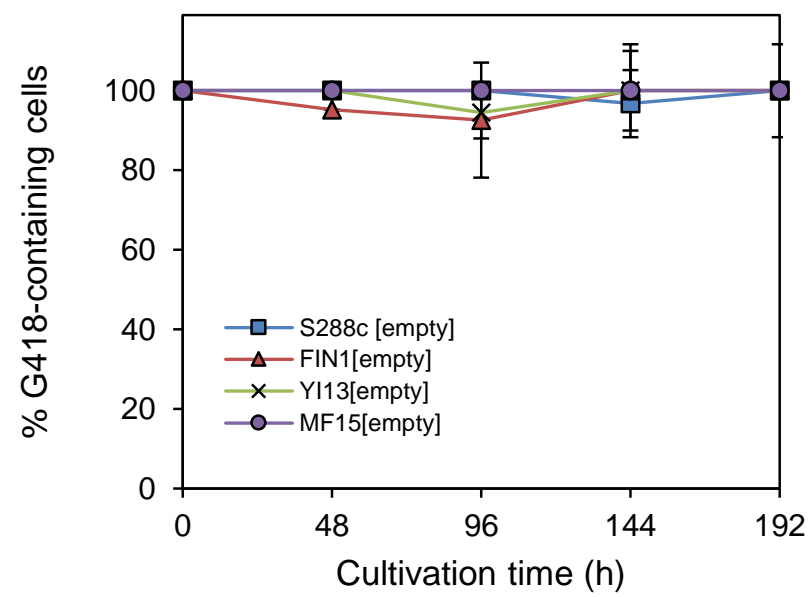

Figure 3.8. Genetic stability of $S$. cerevisiae transformants expressing the gene kanMX from (a) episomal plasmids or (b) $\delta$-integrated gene cassettes. 
Breeding polyploid yeast strains has been shown to improve not only ethanol productivity, but also protein production (64). Therefore, it is necessary to determine the ploidy of the natural strains in comparison to reference strains. For the purposes of this study, reference strains S288c and Y294 were constructed to be diploid. For ploidy determination, the mating type PCR was utilised to confirm the presence of both mating type alleles, the MATa and MAT $\alpha$ for superior natural strains and the reference strains (data not shown). This was done in combination with sporulation and flow cytometry analysis to determine the relative DNA content within the cells. Sporulation was induced using $1 \%$ potassium acetate agar plates and microscopic analysis was performed using $100 \mathrm{X} 1.3$ objective using a differential interference contrast (DIC). The results suggest a higher ploidy state than haploid in the natural strains (Figure 3.9a). Microscopic analysis indicated that all the strains were able to sporulate and produce four ascospores. As expected, we did not detect spores from the control haploid S288c, however the constructed diploid S288c, MH1000, YI13, FIN1, MF15 showed many asci containing four spores.

We carried out flow cytometry for a more accurate determination of cell ploidy. Major subpopulations can be differentiated using forward scatter light (FSC) and side scatter light (SSC) as indicated in Addendum, Figure 2A (49). A gate is drawn around the population of interest, to isolate events for analysis or sorting (50). Data for events within this gate are displayed in subsequent histogram plots which allows you to view a single parameter against the number of events (Figure 3.9b). In the graphs that follow, the fluorescence data from gated events are used to determine the percentages of various subpopulations (subsets) present (Addendum, Figure 3A). A subclass control strain is used to determine where the markers will be placed, in this case haploid and diploid transition states of the control haploid S288c (50 fluorescent units) and diploid MH1000 cells (100 fluorescent units). All cells had the characteristic two peaks; one peak represents the G1 and another (with twice the channel value) represents the G2/M phase of the cell cycle (Figure 3.9b). Using a DNA diploid reference (control sample), we identified the diploid peak in the six natural strains, including the superior natural strains YI13, FIN1 and MF15. It was also noted that the strains FIN1, YI59 and YI13 had additional peaks suggesting haploid state, but this could be due to the natural strains reaching stationary phase very rapidly and skewing the data or that more than one cell population was present. This data, therefore, suggests that the high heterologous enzyme activity observed by the YI13 and FIN1 strains was not influenced by the differences in the ploidy state between the strains, as all the strains were confirmed diploid. 
(a)

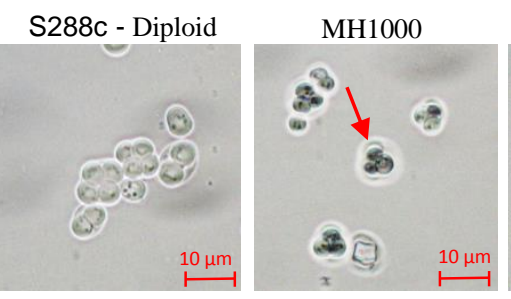

FIN1

MF15
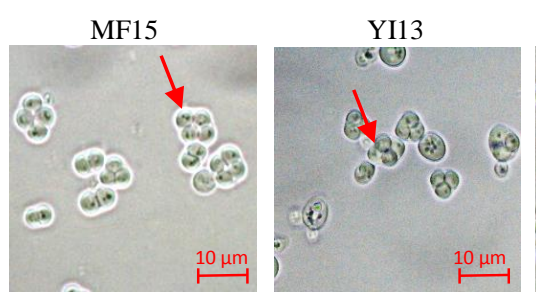

Haploid ref.

(b)
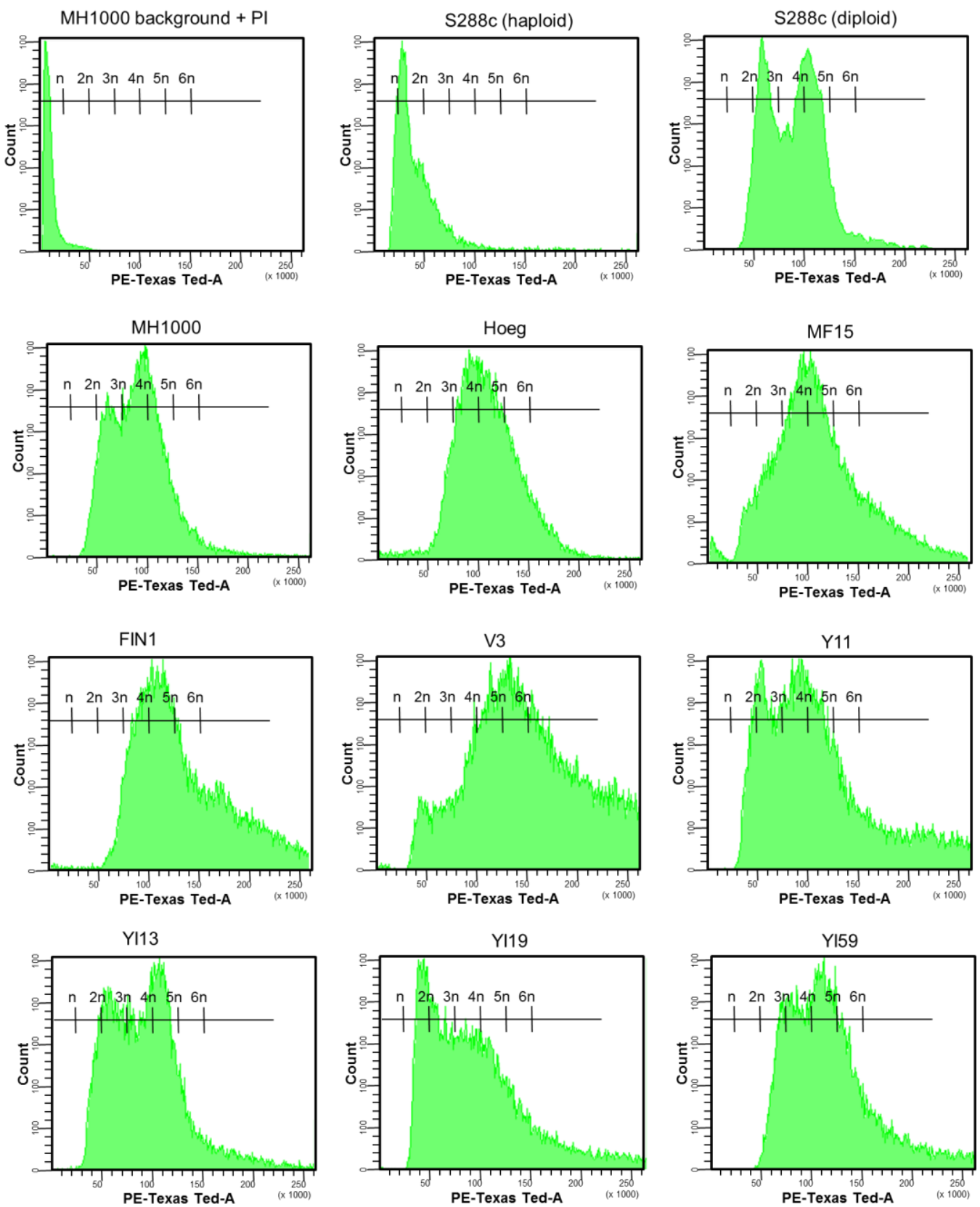

Figure 3.9. Ploidy determination. (a) Yeast ascospores are indicated by the arrows. (b) Histograms comparing control populations (haploid S288c strain) with stained populations: vertical axis represents number of cells within an intensity channel. Horizontal axis to measure fluorescent intensity; here 250 channels were used. The two peaks present in the histograms are a result of different cell populations. One peak represents the G1 and another (with twice the channel value) represents the G2/M phase of the cell cycle. 


\subsubsection{Growth rates between transformants}

Yeasts are well established for the production of a wide range of recombinant proteins but there are limitations e.g., metabolic and cellular stresses that have a strong impact on recombinant protein production (23). Expression of recombinant proteins often triggers many physiological changes, resulting in metabolic burden and reduction of cell growth and protein production (23). Therefore, differences in cellulolytic enzyme production and secretion may arise from divergences in cell growth (24). Since the natural strain YI13 demonstrated relatively high cellulolytic enzyme activity; the effect of cellulolytic enzyme production on growth kinetics was determined in comparison to the reference strain S288c. The growth performance of transformants containing episomal plasmids expressing either S.f.cel3A, T.r.cel5A, T.e.cel7A genes or an empty vector was measured over a cultivation period of $62 \mathrm{~h}$ in YPD (Figure 3.10).
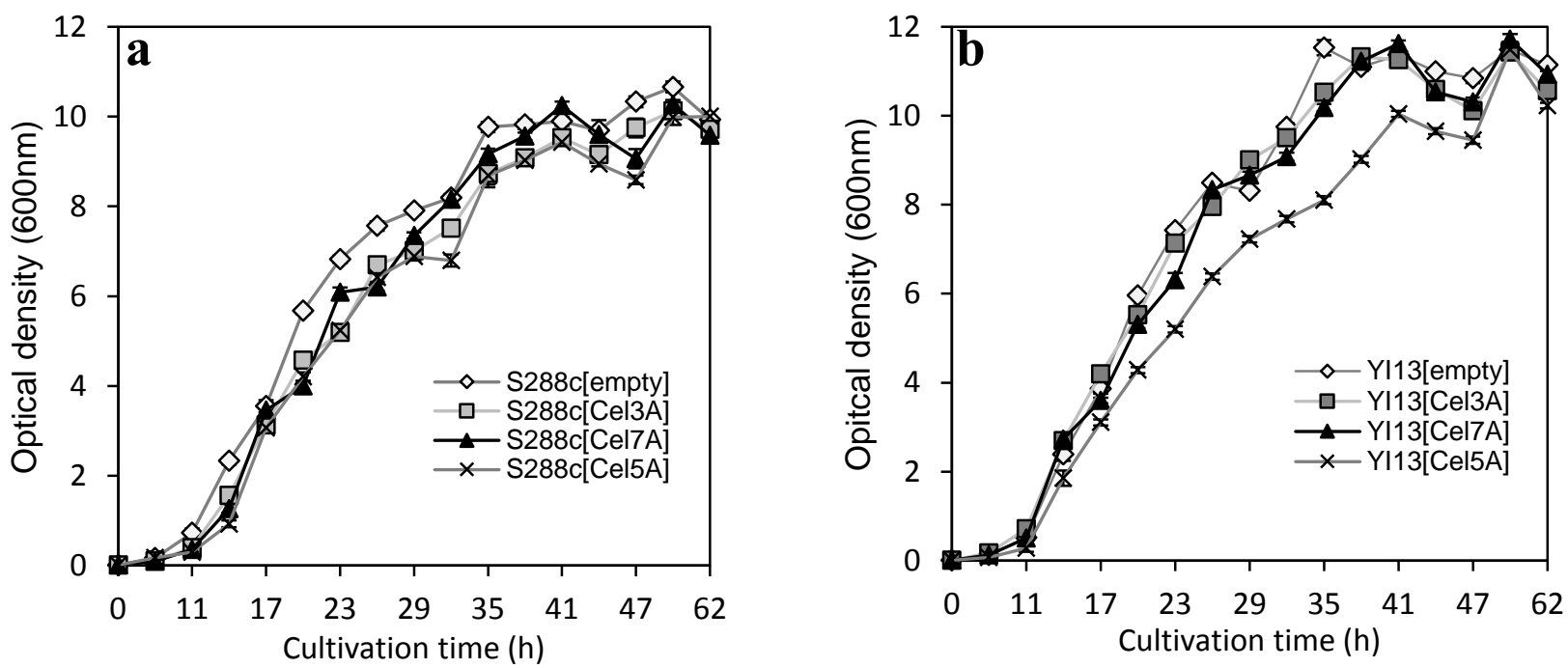

Figure 3.10. Growth curves of the (a) S288c reference transformants and (b) YI13 transformants episomally expressing S.f.cel3A, T.r.cel5A and T.e.cel7A genes or an empty plasmid during the cultivation period in YPD. Absorbance was measured at $600 \mathrm{~nm}$. Mean values from triplicate experiments are shown and error bars indicate the standard deviation from the mean.

The YI13 transformants reached higher OD ${ }_{600 \mathrm{~nm}}$, in the range of $\mathrm{OD}_{600 \mathrm{~nm}} 12.19-9.65$, compared to $\mathrm{S} 288 \mathrm{c}$ transformants which had a range of $\mathrm{OD}_{600 \mathrm{~nm}} 10.00-9.50$. The majority of the heterologous gene expressions had no significant $(p>0.05)$ deleterious effect on the growth capability of the yeasts. However, the expression of T.r.cel5A gene from an episomal plasmid appeared to have a substantial strain on the energy metabolism of the YI13[Cel5A] based on the growth rate value that was statistically significantly lower than that of the empty control strain YI13[empty], but also lower than the reference strain S288c[Cel5A] (Table 3.4). The high secretor strain YI13[Cel5A], illustrated a notable decrease in growth rate $\left(0.43 \mu \mathrm{max} / \mathrm{h}^{-1}\right)$ 
relative to control strain YI13[empty] $\left(0.53 \mu \mathrm{max} / \mathrm{h}^{-1}\right)$ (Table 3.4), suggesting that heterologous enzyme production is counterproductive to yeast biomass production; therefore negatively growth related. An increase in the volumetric activity of T.r.Cel5A was thus counteracted by a decrease in the formation of protein-producing biomass. The diminished growth rate becomes prevalent after $29 \mathrm{~h}$ (Figure 3.10b), after the cultures had entered diauxic growth, a period where the yeast switched its metabolism from utilising glucose through glycolysis to utilisation of ethanol (70). Although T.r.Cel5A production seems to have a significant impact on the growth rate of the YI13 strain, the transformant reaches the same high optical densities after $62 \mathrm{~h}$ compared to the control YI13[empty] (Figure 3.10). The decreased growth rate could be due to higher protein expression levels, however this could not be confirmed as the native proteins levels interfered with protein determination analysis (Addendum, Figure 6A). However, it is important to note that previous studies have demonstrated variation in not only growth rate and density, but also in cell size.

Table 3.4. Maximum specific growth rate of the plasmid-containing reference strain S288c and the natural strain YI13.

\begin{tabular}{llc}
\hline Strain & Heterologous $\operatorname{protein}^{\mathrm{c}}$ & $\mu \mathrm{max}^{\mathrm{abd}}\left(\mathrm{h}^{-1}\right)$ \\
\hline S288c & Empty vector & $0.51 \pm 0.01$ \\
& S.f.Cel3A & $0.52 \pm 0.05$ \\
& T.r.Cel5A & $0.48 \pm 0.02$ \\
& T.e.Cel7A & $0.55 \pm 0.05$ \\
YI13 & Empty vector & $0.53 \pm 0.02$ \\
& S.f.Cel3A & $0.49 \pm 0.03$ \\
& T.r.Cel5A & $0.43 \pm 0.02$ \\
& T.e.Cel7A & $0.52 \pm 0.01$ \\
\hline
\end{tabular}

${ }^{\mathrm{a}}$ Standard deviations from biological triplicate experiments are indicated by \pm .

${ }^{\mathrm{b}}$ Maximum velocity was obtained from the slope of the growth curves from time period of $8-29 \mathrm{~h}$.

${ }^{\mathrm{c}}$ The transformants carrying either pMUSD1/2/3 are denoted S.f.Cel3A/ T.r.Cel5A/ T.e.Cel7A, respectively.

${ }^{\mathrm{d}}$ Specific growth rates significantly lower than the control empty vector strains are indicated with ${ }^{\dagger}$.

In this work we investigated the effect of specific growth rate on the production of cellulases in two different strains of $S$. cerevisiae. In a previous study, S. cerevisiae had achieved the highest yield of $\beta$-galactosidase at the lowest specific growth rate (71) and that the specific activity of cuntinase decreases with increasing specific growth rates $(72,73)$. Andersen et al. (74) has reported that the production of heterologous proteins is either growth associated (reaching a plateau at high specific rate) or inversely associated with growth, depending on cell lines, protein's properties and expression systems. Our study revealed that FIN1 transformants expressing cellulase genes have relatively low growth rates (Addendum, Figure 7A), which 
may be beneficial for cell-specific S.f.Cel3A activity. However, for T.r.Cel5A and T.e.Cel7A specific activities, the higher growth rates of the YI13 strain proved to be beneficial.

\subsubsection{Fermentation and $S . f$. Cel3A activity in oxygen-limited conditions}

Oxygen is an important parameter in cellular metabolism, as well as protein production due to its role in assisting oxidative protein folding (75). Generally, most recombinant proteins are produced at higher levels in highly aerobic fermentation (7). However, several studies have indicated that anaerobic conditions seem to be more favourable in terms of producing recombinant proteins. For example the studies by Liu et al. (76) and Cha et al. (77) demonstrated that $S$. cerevisiae had increased production of $\alpha$-amylase and glucoamylase volumetric activity levels respectively when cultured anaerobically. Likewise in P. pastoris, the human Fab fragment production was increased under anaerobic conditions (10). Therefore, as a starting point to assess the ethanol titers and cellulolytic enzyme activities under fermentation conditions, the episomal transformants expressing the gene S.f.cel3A were cultivated in oxygen-limited conditions. Bioethanol production processes are carried out under such conditions because maintenance of high aeration is difficult and expensive (78). The fermentation profiles of the six transformed natural strains FIN1[Cel3A], YI13[Cel3A], V3[Cel3A], YI19[Cel3A], YI59[Cel3A] and YI1[Cel3A] and the reference strains MH1000[Cel3A] and S288c[Cel3A] are investigated under oxygen-limited conditions in YP media with $2 \%$ glucose. The theoretical maximum ethanol production was calculated from the stoichiometry of the metabolic pathway, with $1 \mathrm{~mol}$ of glucose rendering $2 \mathrm{~mol}$ of ethanol, i.e. $0.511 \mathrm{~g}$ ethanol/ g glucose (79).

The efficiency for converting glucose to ethanol was analysed for the six transformants as an initial control of the intrinsic fermentative capabilities arising from the host strains (Table 3.5). There is a variation in the fermentation profiles among natural, commercial and laboratory S. cerevisiae strains. Although the eight strains did not differ significantly $(p<0.05)$ in the ethanol titers, the commercial strain MH1000[Cel3A] had the highest ethanol titer of $9.09 \mathrm{~g} / \mathrm{L}$ after $96 \mathrm{~h}$ (88\% of the theoretical yield) (Table 3.5). The two recombinant strains YI13[Cel3A] and FIN1[Cel3A] produced relatively high ethanol titers of $9.02 \mathrm{~g} / \mathrm{L}$ and $8.55 \mathrm{~g} / \mathrm{L}$, compared with the industrial strain MH1000[Cel3A] $(9.09 \mathrm{~g} / \mathrm{L})$ after $96 \mathrm{~h}$, thus corresponding to $89 \%$ and $84 \%$ of the theoretical maximum yield, respectively. 
Table 3.5. Remarkable physiological and technological differences in the fermentation profiles of natural S. cerevisiae transformants expressing S.f.cel3A on episomal plasmids in YPD medium under oxygen-limited conditions ${ }^{\mathrm{a}}$.

\begin{tabular}{|c|c|c|c|c|c|c|c|c|}
\hline & MH1000 & $\mathrm{S} 288 \mathrm{c}$ & V3 & FIN1 & YI19 & YI59 & YI1 & YI13 \\
\hline \multicolumn{9}{|l|}{ Product titres $^{\mathrm{b}}(\mathrm{g} / \mathrm{L})$} \\
\hline Cell biomass & $8.79 \pm 0.1$ & $7.11 \pm 0.0$ & $7.01 \pm 0.0$ & $4.80 \pm 0.1$ & $7.91 \pm 0.1$ & $5.32 \pm 0.1$ & $7.20 \pm 0.1$ & $9.01 \pm 0.1$ \\
\hline Residual glucose & $0.26 \pm 0.1$ & $0.17 \pm 0.0$ & $0.21 \pm 0.1$ & $0.51 \pm 0.5$ & $0.54 \pm 0.1$ & $0.21 \pm 0.4$ & $0.50 \pm 0.1$ & $0.17 \pm 0.3$ \\
\hline Glycerol titre & $\begin{array}{l}1.16 \pm \\
0.81\end{array}$ & $1.14 \pm 0.89$ & $0.97 \pm 0.68$ & $\begin{aligned} 1.41 \pm \\
30.08\end{aligned}$ & $\begin{array}{l}1.08 \pm \\
0.01\end{array}$ & $\begin{array}{l}1.44 \pm \\
0.07\end{array}$ & $\begin{array}{l}1.19 \pm \\
0.08\end{array}$ & $\begin{array}{l}1.09 \pm \\
0.00\end{array}$ \\
\hline Ethanol yield (\%) & \multicolumn{3}{|c|}{$88.0 \% \pm 0.489 .2 \% \pm 0.2 \begin{array}{l}88.6 \% \\
0.9\end{array}$} & \multicolumn{5}{|c|}{$83.9 \% \pm 0.288 .5 \% \pm 0.186 .1 \% \pm 0.286 .6 \% \pm 0.988 .5 \% \pm 0.0$} \\
\hline Ethanol titre & $\begin{array}{l}9.09 \pm \\
0.02\end{array}$ & $\begin{array}{l}8.98 \pm \\
0.01\end{array}$ & $\begin{array}{l}9.03 \pm \\
0.03\end{array}$ & $\begin{array}{l}8.55 \pm \\
0.03\end{array}$ & $\begin{array}{l}9.03 \pm \\
0.01\end{array}$ & $\begin{array}{l}8.78 \pm \\
0.01\end{array}$ & $\begin{array}{l}8.83 \pm \\
0.01\end{array}$ & $\begin{array}{l}9.02 \pm \\
0.04\end{array}$ \\
\hline Acetate titre & \multicolumn{3}{|c|}{$0.81 \pm 0.010 .89 \pm 0.01 \begin{array}{l}0.68 \\
\pm 0.01\end{array}$} & \multicolumn{5}{|c|}{$0.72 \pm 0.030 .87 \pm 0.010 .78 \pm 0.010 .74 \pm 0.000 .93 \pm 0.01$} \\
\hline \multicolumn{9}{|l|}{ S.f.Cel3A activity $(\mathrm{U} / \mathrm{mg} \mathrm{DCW})^{\mathrm{c}}$} \\
\hline Total cell activity & $\begin{array}{l}1.77 \pm \\
0.50\end{array}$ & $\begin{array}{l}3.504 \pm \\
1.03\end{array}$ & $\begin{array}{l}3.86 \pm \\
1.15\end{array}$ & $\begin{array}{l}15.97 \pm \\
0.28\end{array}$ & $\begin{array}{l}2.91 \pm \\
1.32\end{array}$ & $\begin{array}{l}1.56 \pm \\
0.26\end{array}$ & $\begin{array}{l}2.50 \pm \\
1.09\end{array}$ & $2.60 \pm 0.75$ \\
\hline Supernatant activity & $\begin{array}{l}0.607 \pm \\
0.13\end{array}$ & $\begin{array}{l}1.233 \pm \\
0.32\end{array}$ & $\begin{array}{l}0.28 \pm \\
0.15\end{array}$ & $\begin{array}{l}3.69 \pm \\
0.15\end{array}$ & $\begin{array}{l}0.34 \pm \\
1.11\end{array}$ & $\begin{array}{l}1.00 \pm \\
1.21\end{array}$ & $\begin{array}{l}1.20 \pm \\
0.83\end{array}$ & $\begin{array}{l}0.78 \pm \\
0.156\end{array}$ \\
\hline$\%$ S.f.Cel3A released into supernatant & $34 \% \pm 0.48$ & $335 \% \pm 0.67$ & $\begin{array}{l}7.5 \% \pm \\
1.14\end{array}$ & $\begin{array}{l}23 \% \pm \\
0.23\end{array}$ & $\begin{array}{l}12 \% \pm \\
0.71\end{array}$ & $\begin{array}{l}64 \% \pm \\
1.18\end{array}$ & $\begin{array}{l}48 \% \pm \\
0.71\end{array}$ & $\begin{array}{l}30 \% \pm \\
0.73\end{array}$ \\
\hline
\end{tabular}

${ }^{a}$ Experiments were carried out in YP medium with $20 \mathrm{~g} / \mathrm{L}$ glucose, $200 \mathrm{rpm}, 30^{\circ} \mathrm{C}$. Reaction proceeded for $96 \mathrm{~h}$. Standard deviations from biological duplicate experiments are indicated by \pm .

${ }^{\mathrm{b}}$ Product titres were based on final concentration of products after $96 \mathrm{~h}$.

${ }^{\mathrm{c}} S$.f.Cel3A activity (U/mg dry cell weight) was based on final enzyme activity levels after $96 \mathrm{~h}$. 
The YI13[Cel3A] and reference MH1000[Cel3A] consumed glucose faster than the FIN1[Cel3A] (0.51 g/L) and S288c[Cel3A] $(0.17 \mathrm{~g} / \mathrm{L})$, with low residual glucose concentrations of $0.17 \mathrm{~g} / \mathrm{L}$ and $0.26 \mathrm{~g} / \mathrm{L}$, respectively, and higher optical densities, $\mathrm{OD}_{600 \mathrm{~nm}}$ 9.01 and 8.79, respectively, after $96 \mathrm{~h}$ compared to the strain FIN1[Cel3A] (OD600nm 4.8) and S288c[Cel3A] (7.12 g/L) (Figure 3.11b \& f). The YI13 strain demonstrates high growth rates and high final cell biomass during aerobic oxygen-limited conditions (Figure 3.11f).
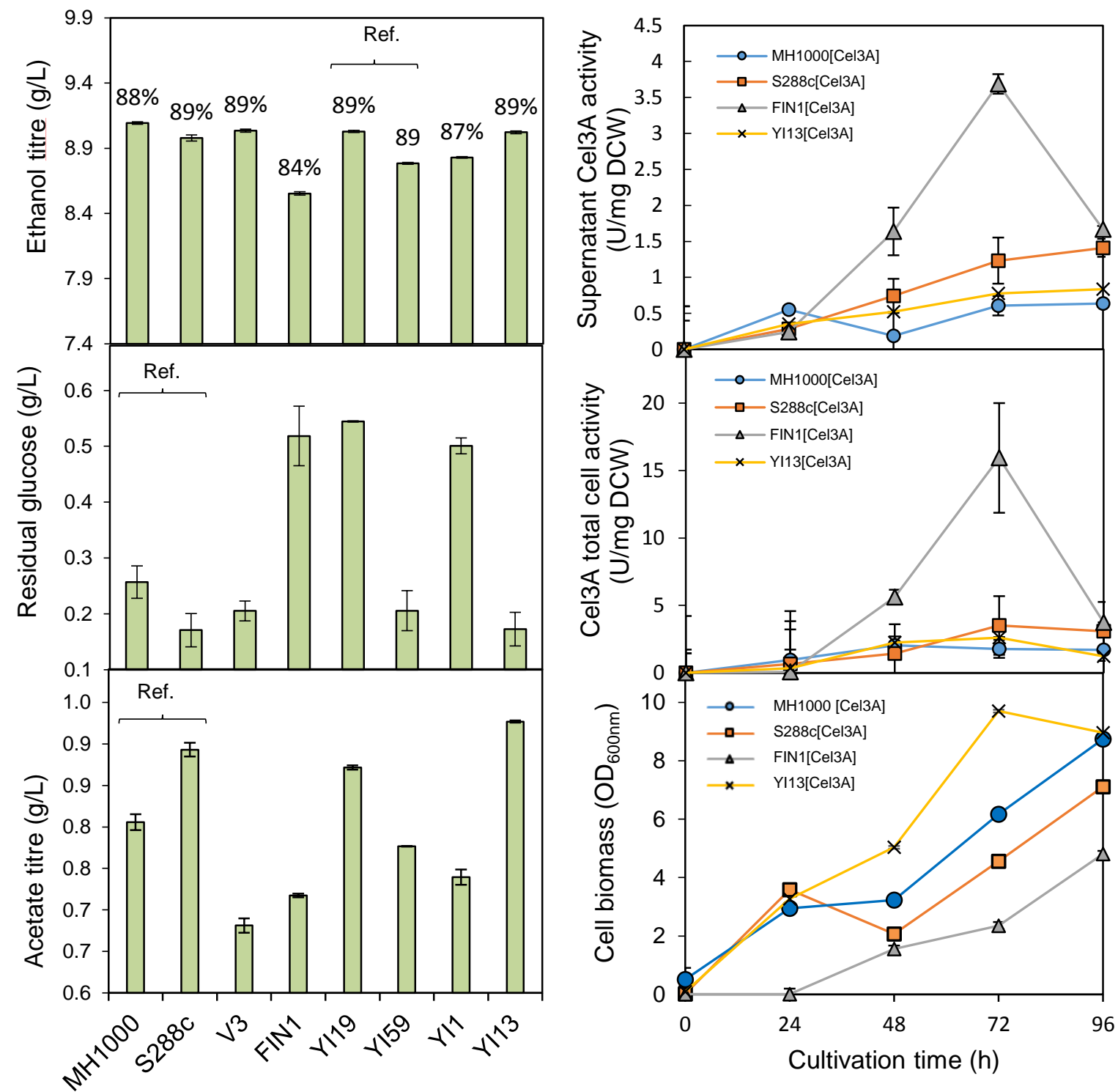

Figure 3.11. Fermentation and recombinant $S . f$.Cel3A activity profiles of natural strains compared to the reference strains MH1000 and S288c. Graphs display (a) ethanol titer and (b) residual glucose and (c) acetate produced at end point after $96 \mathrm{~h}$, and (d) supernatant and (e) total cell S.f.Cel3A activity, and (f) cell biomass over the period of $96 \mathrm{~h}$. Error bars are standard deviations from the mean calculated from three biological triplicates. The percentages are the calculated theoretical ethanol yields. Reference strains are indicated as Ref. on the graphs. 
Although the strains resulted in similar ethanol titers ranging from 8.6-9.1 g/L, the concentrations of the secondary products differed considerably after $96 \mathrm{~h}$. The FIN1[Cel3A], S288c[Cel3A] and YI19[Cel3A] strains demonstrate the highest acetate production titers ranging from $0.93-0.87 \mathrm{~g} / \mathrm{L}$ after $96 \mathrm{~h}$ compared to all the transformants. Acetate production is an undesirable characteristic in bioethanol producing strain since this compound is inhibitory and directs the carbon flow push away from the desired ethanol production (75).

No difference in terms of ranking of the cell-specific S.f.Cel3A activity levels is observed in different culturing conditions. Under oxygen-limited conditions, cell-specific S.f.Cel3A activity levels of the FIN1[Cel3A] continued to be significantly higher than that of the reference strain S288c[Cel3A] (Figure 3.11d \& e). As shown in Figure 3.11d, S.f.Cel3A enzyme secreted cell specific activity levels continued to be highest for the FIN1[Cel3A] strain (producing up to $3.69 \mathrm{U} / \mathrm{mg}$ DCW after $72 \mathrm{~h}$ ) compared to all the transformants evaluated. Interestingly, the same strain resulted in moderate ethanol titers $(8.4 \mathrm{~g} / \mathrm{L})$ (Figure 3.11a) but consumed glucose the slowest resulting in relatively high residual glucose concentration $(0.52 \mathrm{~g} / \mathrm{L})$ remaining after $96 \mathrm{~h}$ fermentation compared to the other recombinant strains (Figure 3.11b \& $\mathbf{f}$ ), indicating that this strain is more effective for the conversion of glucose to ethanol than to biomass. The difference in growth rates likely results in lower ER throughput, therefore less stress, resulting in higher S.f.Cel3A secreted activity. This suggests that for S.f.Cel3A production slow growing strains are required for high production levels.

A majority of the strains had an increase in supernatant S.f.Cel3A activity levels and higher percentage of $S . f$.Cel3A released into the medium under oxygen-limited conditions compared to aerobic conditions (Table 3.2 and Table 3.5). Under oxygen-limited conditions, the FIN $[\mathrm{Cel} 3 \mathrm{~A}]$ and the reference strain $\mathrm{S} 288 \mathrm{c}[\mathrm{Cel} 3 \mathrm{~A}]$ have an increase in supernatant activity (2.2-fold and 10.3-fold, respectively) (Table 3.5), in comparison to aerobic conditions (Table 3.2). This result suggests that the cell-specific secreted activities of these strains are improved under oxygen-limited conditions. Recent research has demonstrated that $\alpha$-amylase enzyme production from $S$. cerevisiae in aerobic conditions is limited by the protein folding capacity and that higher productivity can be obtained under anaerobic conditions (80). The amylase yield increased 2-fold in anaerobic cultivation compared to aerobic conditions suggesting that amylase tends to gain higher production and reduced rates of ER misfolding in these conditions. The increase in supernatant S.f.Cel3A activity observed in this study could be due to the cell wall structure changing during anaerobic fermentation conditions (81), resulting in the release 
of the S.f.Cel3A that is attached to the cell wall or in periplasmic space into the culture supernatant. Another possible reason for this phenomenon is that the FIN1[Cel3A] has significantly slower growth rates during aerobic and in oxygen-limited cultivations. Therefore, although the volumetric activities are higher in aerobic conditions, the increase in biomass resulted in the cell specific activities to be lower in aerobic conditions.

\subsubsection{Co-culture fermentations using Avicel cellulose}

The plasmid-containing transformants producing individual T.r.Cel5A (EGII), T.e.Cel7A (CBHI) and S.f.Cel3A (BGLI), as described in this study, permit us to study their singular and combined effectiveness in utilising cellulosic substrate (20 g/L Avicel) at cell consortia levels. The use of microbial consortia for industrial production of bio-products has not yet been studied to any great extent (82). The main advantage of using a consortia co-culture system is the flexibility that is absent in mono-cultures systems of individual strains for the rational design of secretome compositions (54). Microbial consortia, also known as co-fermentation systems, have been studied due to their usefulness in bio-processing (83), moreover consortia can consist of multiple species or a single species with different engineered lines (82).

In this study, the capability of recombinant $S$. cerevisiae episomal transformants to utilise cellulose was evaluated by firstly growing the transformants in YPD media for $72 \mathrm{~h}$, before the addition of Avicel cellulose was added as a sole carbon source. A mono-culture of S. cerevisiae [Empty vector], a binary culture of $S$. cerevisiae [Cel5A] and [Cel7A], and tertiary cultures of S. cerevisiae [Cel3A], [Cel5A] and [Cel7A] were utilised, respectively. These cultures were analysed at $48 \mathrm{~h}, 96 \mathrm{~h}$ and $148 \mathrm{~h}$ during the fermentation, and differences in the appearance of the precipitate at the bottom of the cultures were observed (Addendum, Figure 8Aa and Figure 3.12). Immediately after $148 \mathrm{~h}$ fermentation, images were taken of the cultures (Addendum, Figure 8Aa). For cultures inoculated with the empty vector transformants, the Avicel and cell precipitate appear compact, whereas the precipitates of various cultures of S. cerevisiae transformants appeared swollen - possibly indicating changes in the cellulose caused by the heterologous cellulase activity. After allowing the precipitate to settle for $48 \mathrm{~h}$, less Avicel residue was observed in the cultures inoculated with transformants expressing 
cellulase genes than the cultures inoculated with the empty vectors controls, further suggesting hydrolysis of the Avicel cellulose (Figure 3.12a \& b).

(a)

(b)

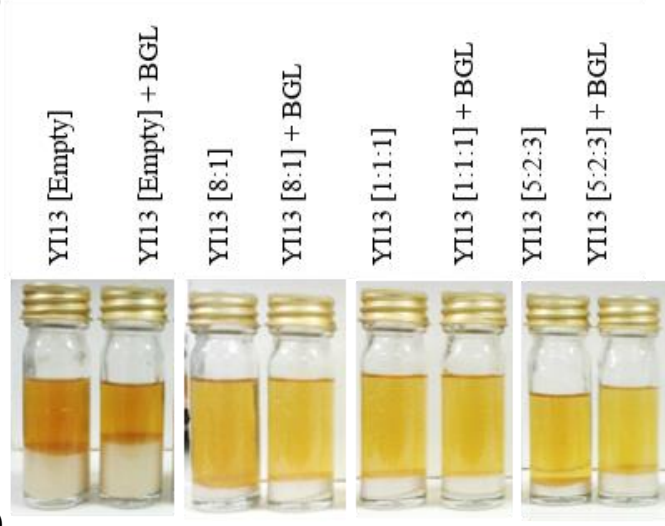

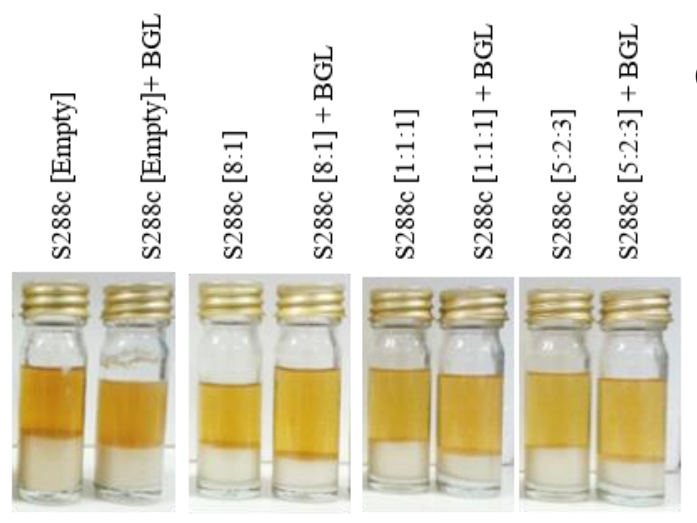

(c)

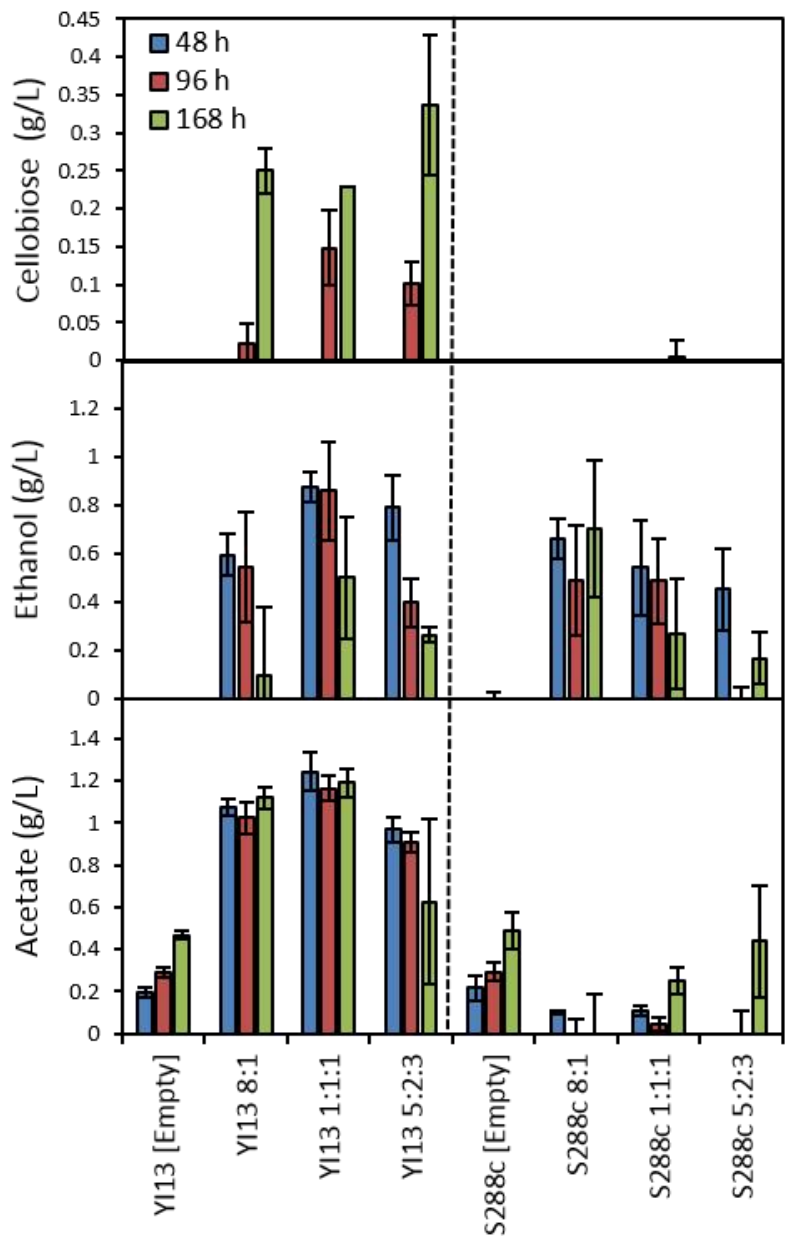

Figure 3.12. Co-culture fermentations of $S$. cerevisiae transformants secreting S.f.Cel3A, T.r.Cel5A and T.e.Cel7A activity in $25 \mathrm{~mL}$ YPD media containing $0.5 \mathrm{~g}$ Avicel (equivalent to $2 \% \mathrm{w} / \mathrm{v}$ ) as sole carbon source. Co-culture ratios of 8:1, 1:1:1 and 5:2:3 were calculated based on cell-specific supernatant activity levels, in the order of [Cel7A]:[Cel5A] for binary cultures and [Cel7A]:[Cel5A]:[Cel3A] for tricultures, respectively. (a and b) Images of the precipitate that settled after $48 \mathrm{~h}$ after fermentation (with and without the external addition of 188 Novozyme). (c) Levels of accumulated cellobiose measured in the supernatant of fermentation at $48 \mathrm{~h}, 96 \mathrm{~h}$ and $168 \mathrm{~h}$. (d) Levels of ethanol and (e) acetate produced in the supernatant during the fermentation at $48 \mathrm{~h}, 96 \mathrm{~h}$ and $148 \mathrm{~h}$. The values shown are the mean values of three repeats \pm standard deviations.

As described above in the Section 3.3.1, the cellulase activity secretion yield varies for different $S$. cerevisiae transformants, specifically, the secretion activity yield for $S . f$.Cel3A, T.r.Cel5A and T.e.Cel7A was approximately $10.0 \mathrm{U} / \mathrm{mg} \mathrm{DCW}, 1.75 \mathrm{U} / \mathrm{mg}$ DCW and 
0.25 U/mg DCW for YI13 transformants and approximately $2.8 \mathrm{U} / \mathrm{mg}$ DCW, $6.50 \mathrm{U} / \mathrm{mg}$ DCW and $0.78 \mathrm{U} / \mathrm{mg}$ DCW. Co-cultures were prepared by adding the appropriate volumes of cultures to make up $25 \mathrm{~mL}$ of cultures containing $0.5 \mathrm{~g}$ Avicel. The targeted cellulase activity rations were based on reported optimal ratio for cellulose hydrolysis (69). The capabilities of S. cerevisiae transformants to utilise cellulose was evaluated by growing transformants in the YPD media with Avicel as the carbon source. While the mono-cultures of the empty transformants produced no ethanol, these parameters increased to $0.27 \mathrm{~g} / \mathrm{L}$ ethanol for the triculture of S288c [1:1:1], and up to $0.50 \mathrm{~g} / \mathrm{L}$ ethanol for the tri-culture YI13 [1:1:1] after $168 \mathrm{~h}$, without added 188 Novozyme (Sigma) (Figure 3.12d). Several studies have examined alcohol yields from the hydrolysis of cellulose with recombinant cellulase genes expressed in yeasts (84-87). It is difficult to compare the alcohol production from cellulose hydrolysis by these studies due to variation in experimental parameters, such as starting substrate concentration, incubation times and combination of cellulase genes used but in general alcohol yields in all studies are in the order of 1-7 g/L, as recently reviewed by Kricka et al. (69).

Co-culture fermentations with Avicel were also performed with and without externally added BGLI (188 Novozyme [Sigma]) and chemical analysis was performed on the culture media using HPLC. The analysis results of all the culture supernatants are summarised in Table 3.6. Ethanol production is higher with externally added BGL (referred to as +BGL), with the YI13 co-cultures producing higher ethanol titers (in the range of $0.82-0.86 \mathrm{~g} / \mathrm{L}$ ) than the reference S288c co-cultures (in the range of 0.22-0.76 g/L) in $25 \mathrm{~mL}$ Avicel-YPD media after $168 \mathrm{~h}$ (Table 3.6). Overall, the results from this study demonstrates that ethanol was produced by transformants, although low yields are observed compared to previous studies. This could be due to too low enzyme activity yields, especially the T.e.Cel7A and T.r.Cel5A activity. It is possible, however, that under different fermentation conditions the natural strains may have higher yields as they confer innately high tolerance to industrial process. 
Table 3.6. Co-culturing of S. cerevisiae transformants expressing heterologous cellulase genes in $25 \mathrm{~mL}$ medium containing $0.5 \mathrm{~g}$ Avicel (equivalent to $2 \%$ $\mathrm{w} / \mathrm{v}$ ) as a sole carbon source.

\begin{tabular}{lccccccccccc}
\hline \multirow{2}{*}{ Co-cultures } & \multicolumn{2}{c}{ Ethanol $^{\mathrm{a}}(\mathrm{g} / \mathrm{L})$} & \multicolumn{2}{c}{ Cellobiose $^{\mathrm{b}}(\mathrm{g} / \mathrm{L})$} & \multicolumn{2}{c}{ Residual glucose $^{\mathrm{c}}(\mathrm{g} / \mathrm{L})$} & \multicolumn{2}{c}{ Acetate $^{\mathrm{d}}(\mathrm{g} / \mathrm{L})$} & $\mathrm{Glycerol}^{\mathrm{e}}(\mathrm{g} / \mathrm{L})$ \\
\cline { 2 - 11 } & -BGL & +BGL & -BGL & +BGL & -BGL & +BGL & -BGL & +BGL & -BGL & +BGL \\
\hline YI13 & & & & & & & & & & \\
[empty vector] & $0.00 \pm 0.02$ & $0.00 \pm 0.04$ & $0.41 \pm 0.00$ & $0.27 \pm 0.07$ & $0.14 \pm 0.07$ & $0.12 \pm 0.06$ & $0.47 \pm 0.02$ & $0.28 \pm 0.09$ & $0.22 \pm 0.03$ & $0.23 \pm 0.05$ \\
Bi-culture & $0.09 \pm 0.28$ & $0.82 \pm 0.29$ & $0.84 \pm 0.03$ & $0.52 \pm 0.11$ & $0.22 \pm 0.01$ & $0.27 \pm 0.02$ & $1.12 \pm 0.05$ & $1.10 \pm 0.03$ & $0.44 \pm 0.01$ & $0.46 \pm 0.04$ \\
Tri-culture (1:1:1) & $0.50 \pm 0.25$ & $0.83 \pm 0.12$ & $0.80 \pm 0.00$ & $0.39 \pm 0.01$ & $0.12 \pm 0.05$ & $0.19 \pm 0.03$ & $1.19 \pm 0.07$ & $1.16 \pm 0.12$ & $0.44 \pm 0.06$ & $0.51 \pm 0.05$ \\
Tri-culture (5:2:3) & $0.26 \pm 0.03$ & $0.86 \pm 0.11$ & $0.80 \pm 0.09$ & $0.45 \pm 0.03$ & $0.11 \pm 0.05$ & $0.15 \pm 0.02$ & $0.62 \pm 0.39$ & $0.93 \pm 0.06$ & $0.29 \pm 0.06$ & $0.38 \pm 0.03$ \\
S288c & & & & & & & & & & & \\
[empty vector] & $0.00 \pm 0.02$ & $0.0 \pm 0.04$ & $0.41 \pm 0.00$ & $0.27 \pm 0.07$ & $0.07 \pm 0.06$ & $0.26 \pm 0.07$ & $0.49 \pm 0.09$ & $0.37 \pm 0.01$ & $0.21 \pm 0.05$ & $0.19 \pm 0.06$ \\
Bi-culture & $0.90 \pm 0.28$ & $0.76 \pm 0.29$ & $0.43 \pm 0.03$ & $0.41 \pm 0.11$ & $0.01 \pm 0.01$ & $0.24 \pm 0.05$ & $0.00 \pm 0.19$ & $0.00 \pm 0.21$ & $0.70 \pm 0.09$ & $0.66 \pm 0.07$ \\
Tri-culture (1:1:1) & $0.27 \pm 0.23$ & $0.43 \pm 0.21$ & $0.34 \pm 0.02$ & $0.33 \pm 0.12$ & $0.13 \pm 0.00$ & $0.13 \pm 0.05$ & $0.25 \pm 0.06$ & $0.18 \pm 0.03$ & $0.48 \pm 0.00$ & $0.51 \pm 0.01$ \\
Tri-culture (5:2:3) & $0.17 \pm 0.11$ & $0.22 \pm 0.09$ & $0.31 \pm 0.03$ & $0.25 \pm 0.02$ & $0.26 \pm 0.00$ & $0.08 \pm 0.00$ & $0.43 \pm 0.27$ & $0.13 \pm 0.05$ & $0.43 \pm 0.29$ & $0.59 \pm 0.13$ \\
\hline
\end{tabular}

${ }^{a d}$ Levels of ethanol and acetate produced from strains after $168 \mathrm{~h}$ (subtracted from values measured at $0 \mathrm{~h}$ ).

${ }^{\text {be }}$ Levels of accumulated cellobiose, residual glucose and glycerol from strains after $168 \mathrm{~h}$. 
Another challenge of the current bioethanol production process is that about $4 \%$ of the sugar is lost to formation of the byproduct glycerol and acetate (88). By-product formation was long considered to be an inevitable consequence of the production conditions during bioethanol production (88). Acetate production is more pronounced in YI13 transformants (ranging from $0.47-1.19 \mathrm{~g} / \mathrm{L}$ ) than the reference S288c transformants (ranging $0.0-0.49 \mathrm{~g} / \mathrm{L}$ ) both with and without externally added BGL (Table 3.6). This result suggests that the carbon flow is pushed towards acetate production instead of the desired ethanol production. Research has suggests that acetate production is dependent on NAD+/NADH level in the cytosol as well as the cytosolic acetaldehyde stress (88). Acetaldehyde is a highly stressful and toxic compound and when it accumulates (due to glycolysis overflow), the yeast promptly converts it to acetate, even at the cost of being counter producing regarding cytosolic $\mathrm{pH}$ (88). The $\mathrm{S} 288 \mathrm{c}$ co-cultures have a more pronounced glycerol yields after $168 \mathrm{~h}$ (with the highest yield of $0.70 \mathrm{~g} / \mathrm{L}$ ) compared to the YI13 co-cultures (with the highest yield of $0.51 \mathrm{~g} / \mathrm{L}$ ) (Table 3.6). An inverse correlation exists between glycerol and ethanol production (88), consistent with the results seen in this study. Glycerol production is indicative of cellular stress (88). Generally, correlations exist in elevated glycerol (HOG response) and elevated acetate as a means to restore the skewed redox balance caused by glycerol production due to osmotic stress (89). However, the HOG response varies from strain to strain and depending on the background of each particular strain (89).

\subsubsection{Phenotyping natural strains for bioethanol specific stresses and secretion stresses}

For bioethanol production, the yeast's ability to secrete heterologous cellulolytic enzymes is not the only factor to consider for CBP, but also tolerance to variations in osmotic stress, product inhibition such as ethanol, variation in growth temperature, and presence of toxic compounds $(4,78)$. Unlike the domesticated $S$. cerevisiae strains, environmental isolates are adapted to overcome a variety of environmental stresses (90-97); representing a mostly untapped pool of phenotypic diversity with potential biotechnological applications. To determine differences in the inherent growth abilities of natural and reference strains, we measured viability in the presence of five industrially relevant stress conditions chosen to provoke diverse physiological responses, including high temperatures, variances in $\mathrm{NaCl}$ concentrations, product inhibition and a cocktail of inhibitor compounds that are found in lignocellulosic hydrolysates. First, cells are cultivated on solid media in the presence of each variable, and cell viability is scored relative to an unchallenged control for each strain, a method adapted from Kvitek et al. (55). In order to determine the effect of genetic manipulation on the 
innate tolerance capabilities of the strains, we examine transformants containing either $\delta$-integrated gene expression cassettes or episomal plasmids for any variations in their stress tolerance.

Although there are similarities between strains, no two strains are exactly alike in phenotypic profile, indicating genomic variation between the strains (Figure 3.13). The performances of the natural S. cerevisiae strains are often equally good or, in the case of YI13, superior to the reference strains. The strains were screened against increasing concentrations of ethanol from $8 \%$ to $20 \%(\mathrm{w} / \mathrm{v}$ ) and, after a 12 day incubation the natural strains V3, MF15 and YI13 are found to be more tolerant to ethanol compared to the reference strain S288c. Natural strains could withstand up to $10 \%(\mathrm{w} / \mathrm{v})$ ethanol concentration, however growth is completely inhibited at higher concentrations. To examine a condition that more closely mimics the bioethanol production environment as a whole, we tested viability of wildtype and transformant strains in the presence of high concentrations of $\mathrm{NaCl}(0.6 \mathrm{M}-1.2 \mathrm{M})$, high temperatures $\left(37^{\circ} \mathrm{C}\right.$ and $40^{\circ} \mathrm{C}$ ) and varying concentrations of the inhibitory cocktail originally designed by Martin et al. (29). 


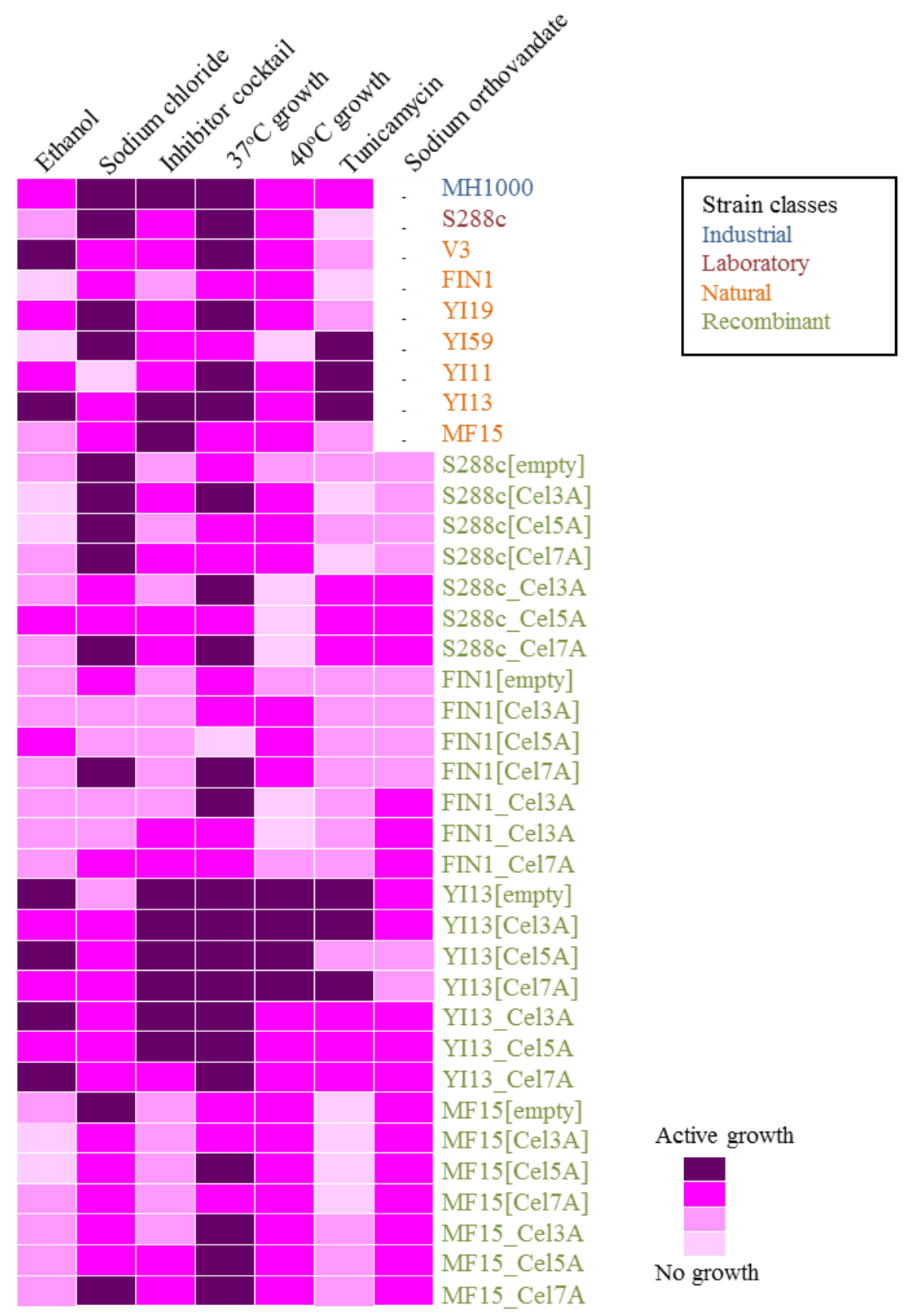

Figure 3.13. Inter-strain diversity of tolerance between natural and reference strains. The viability of seven natural strains, two reference strains MH1000 and S288c, and 28 recombinant strains cultivated under seven different environmental conditions was measured. Each row on the plot represents a different strain and each column indicates a given environment. Coloured boxes represent the average growth rate score of each strain cultivated in each environment, according to the key shown at the lower right as adapted from Kvitek et al. (55). Episomal plasmid-containing strains are indicated with [] symbol, and integrated recombinants are indicted with _ symbol. 
From Figure 3.13, it was concluded that while the tolerance of $S$. cerevisiae to specific inhibitors is strain-dependent (55), several strains demonstrated cross-tolerance to multiple stresses. Not surprisingly the commercial MH1000 strain, used in industry as a distillery yeast (28), is considerably more robust than the laboratory strain S288c; being tolerant to multiple inhibitory factors such as high $\mathrm{NaCl}$ concentrations, high ethanol concentrations, increased temperatures and inhibitory compound. The YI13 transformants also exhibited multi-tolerant characteristics desirable in bioethanol production, i.e. high tolerance to ethanol $(10 \% \mathrm{w} / \mathrm{v})$, hydrolysate inhibitor cocktail (up to $50 \%$ ) and high temperatures $\left(37-40^{\circ} \mathrm{C}\right.$ ). Only the multi-tolerant YI13 wildtype and transformants were able to grow up in 50\% concentration of this medium, therefore demonstrating the ability of the strain to retain its innate tolerance abilities even after transformation. In contrast, the FIN1 strain demonstrated low tolerance to ethanol and the hydrolysate inhibitor cocktail, with growth severely inhibited at $9 \% \mathrm{w} / \mathrm{v}$ ethanol and $50 \%$ concentration of the cocktail. As in nature and industrial applications, yeasts are not exposed to a single stress at a time, but rather exist in complex niches in which many stressful conditions may occur together (94), therefore future research should aim to understand how strains behave when confronted with multiple stresses simultaneously. Better understanding of these regulatory processes may help further exploitation of this organism, and other fungi, for the benefit of industry.

Some of these phenotypic differences observed in this study have been previously reported in the context of other studies $(13,19,95,97-99)$. Carreto et al. (98) demonstrated that gene expression variability is a source of phenotypic diversity among strains. Genome expression plasticity is important in yeast for adaptation to new environments $(18,98)$. For example, genes whose expression are associated with phenotypic variation - such as genes encoding proteins involved in amino acid biosynthesis and transport, sulphur and nitrogen assimilation, and protein degradation are strongly regulated under environmental stress $(99,100)$, resulting in important implications for robustness under environmental stresses. Phenotypic stress assays demonstrated that the natural strain FIN1 had relatively low tolerance to industrial stresses e.g., ethanol, inhibitors and temperature, correlating to the slow growth rates observed by this strain in oxygen-limited conditions (Section 3.3.6) which could have resulted from inhibited growth due to the low concentrations of ethanol in combination with other stress factors. This is in stark contrast to the YI13 strain, which demonstrated high growth rates and tolerance capabilities under oxygen-limited and aerobic conditions. 
While abundant information exists on the stress responses of yeast (mainly $S$. cerevisiae) to environmental changes (101-103), not much is available concerning the connection to heterologous protein productivity with regards to bioethanol-specific stresses. Over the years, it has become clear that metabolic and environmental stresses found in $2 \mathrm{G}$ bioethanol production impact recombinant protein production as reviewed by Mattanovich et al. (23). An intact secretion pathway is important for the cell to withstand environmental conditions (104), and alterations to this pathway result in strains with higher sensitivity to environmental stresses (105). This suggests that there is a trade-off between high secretion capabilities and tolerance to industrial conditions. In order to investigate this hypothesis further, viability stress plates were performed to evaluate the natural strains' resistance to ER stress (induced by tunicamycin [TM]) (106), as well as looking at sensitivity to sodium orthovanadate (indicative of defects in glycosylation and general secretion pathway) (107), Congo Red (CR) (interferes with the construction and stress response of the cell wall) $(108,109)$ and dithiothreitol (DTT) (prevents correct folding of proteins) (110) (details are listed in Addendum, Table 4A).

The plate assays with DTT and sodium orthovanadate demonstrated that the laboratory reference strains S288c and Y294 are more sensitive to ER stresses than the industrial and natural strains (Figure 3.14). From CR plate growth assays, it was clear that the FIN1, YI13 and the laboratory reference strains differ in their cell wall integrity compared to other strains. These strains demonstrated high tolerance to the cell wall stressor CR (up to $400 \mu \mathrm{g} / \mathrm{mL}$ ), however the rest of the strains showed severe sensitivity to CR, although they still showed growth at lower dilution ranges when SC agar was utilised instead of YPD agar (Addendum, Figure 9A). Congo red is known to interfere with the cell wall construction and stress response of the cell wall (109). It is clear that cell wall construction is a dynamic process and that the cell tends to continually adapt the newly formed wall to changing conditions both in terms of cell wall organization and with respect to the cell wall proteins presented at the cell wall surface (109-111). Together, this result raises the possibility that cell wall differences in these strains have been positively selected for when screening for high secretors. Connections between cell wall response and unfolded protein response (UPR) induction have also been studied (111). The UPR maintains ER functionality during exposure to secretion and cell wall stress (111). Therefore, UPR influences secretion and cell wall homeostasis, which in turn impacts upon traits important to industry and biotechnology (111). These results are in accordance with other studies that suggest that cell wall changes might be a primary cause for an enhanced secretion phenotype $(112,113)$. 


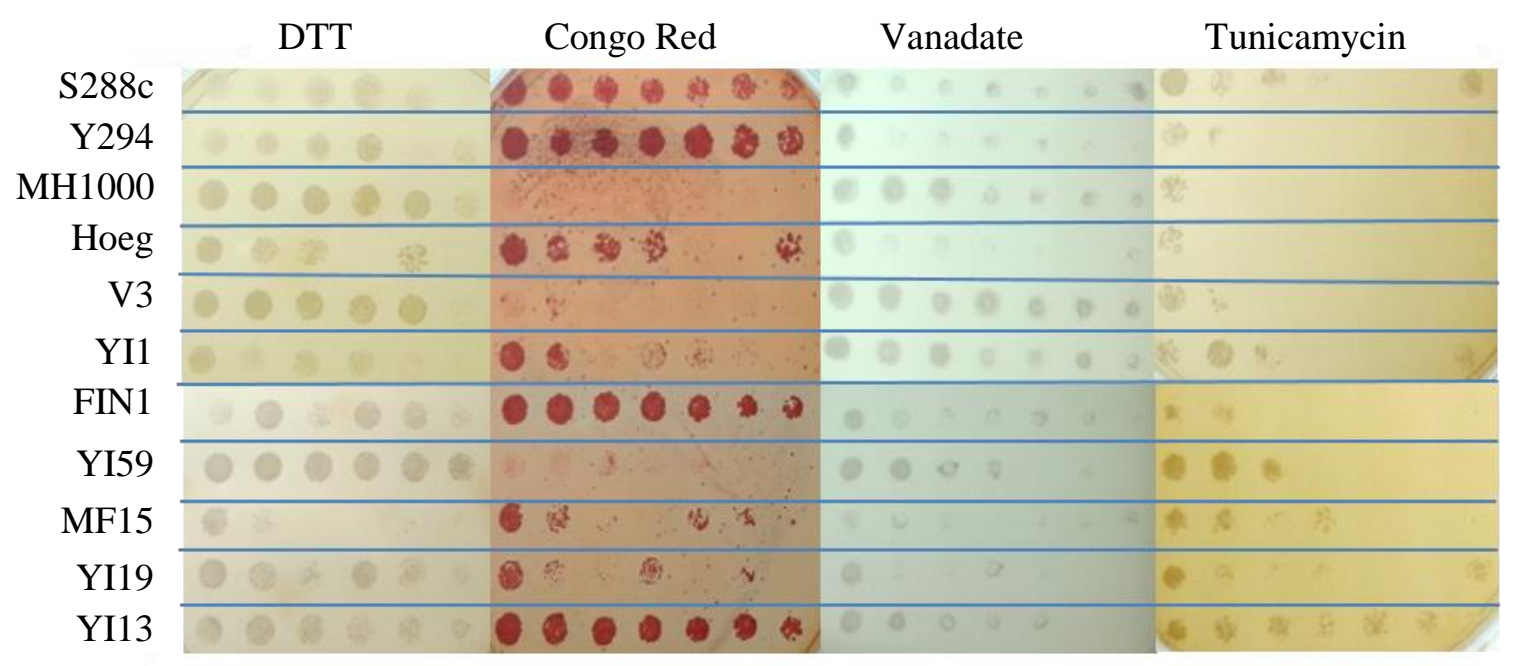

Figure 3.14. Viability analysis of two fold serial dilution of natural strains after $48 \mathrm{~h}$ cultivation SC agar plates supplemented with inhibitors. Resistance to $40 \mu \mathrm{g} / \mathrm{mL}$ DTT, $400 \mu \mathrm{g} / \mathrm{mL} \mathrm{CR}, 200 \mu \mathrm{g} / \mathrm{mL}$ sodium orthovanadate and $0.5 \mu \mathrm{g} / \mathrm{mL}$ tunicamycin was evaluated. Growth for all strains was compared to the reference laboratory strains S288c and Y294, and commercial strains MH1000 and Hoeg, as well as strains cultivated on YPD agar plates without inhibitor supplementation (Addendum, Figure 9A).

From Figure 3.13 \& 3.14, the YI13 strain has demonstrates higher tolerance to secretion stressor TM (withstanding up to $1.0 \mu \mathrm{g} / \mathrm{mL}$ ) compared to the reference strains. This suggests that the natural YI13 strain may have better folding capabilities, allowing the strain to tolerate higher levels of protein processing, resulting in higher secreted cell specific activity levels of heterologous T.r.Cel5A and T.e.Cel7A, as well as tolerance to other stress conditions. A majority of the strains including the reference strain S288c have lowered viability under TM induced stress, with most of the strains inhibited at a relatively low concentration of $0.5 \mu \mathrm{g} / \mathrm{mL}$ TM. As suggested by Ilmén et al. (34) high level secretion of CBH by S. cerevisiae strain could be due to better protein folding capacity relative to other strains. High heterologous protein expression causes ER stress which subsequently activates the unfolded protein response (UPR) which induces genes needed to alleviate stress in the secretory pathway. Studies have indicated that heat shock response proteins HSP (often cytosolic) and the unfolded protein response (an ER response) enhance production of certain heterologous proteins $(114,115)$. Hou et al. (114) demonstrated that the heat shock response (HSR) improves heterologous protein production by releasing ER stress, suggesting a link between tolerance of stress caused by recombinant cellulolytic enzyme production and tolerance to environmental stresses. 


\subsection{Conclusions}

We evaluated and identified natural strains demonstrating superior heterologous cellulolytic activity. Despite being isolated from the natural environment, the YI13 episomal transformants produced promising recombinant T.r.Cel5A and S.f.Cel3A activity levels, while the FIN1 episomal transformant produced high recombinant S.f.Cel3A activity, demonstrating that the genetic background and properties of the protein itself influence recombinant enzyme activity levels. Some of the natural strains were better equipped to survive industrial fermentation conditions, including growth in multiple stresses associated with the bioethanol production. Additionally, our results also illustrated the potential of phenotypically evaluating the natural biodiversity of yeasts to find superior industrial strains that may be useful in biofuel production, providing excellent candidates for further strain improvement though genetic engineering, experimental evolution or breeding. Identifying the genetic elements required for superior recombinant enzyme activity levels and tolerance to industrial stresses may be imperative to engineering optimal strains for CBP.

\subsection{References}

1. Hasunuma T, Okazaki F, Okai N, Hara KY, Ishii J, Kondo A. 2013. A review of enzymes and microbes for lignocellulosic biorefinery and the possibility of their application to consolidated bioprocessing technology. Bioresour Technol 135:513-22.

2. Wilson DB. 2009. Cellulases and biofuels. Curr Opin Biotechnol 20:295-9.

3. Lynd LR, Weimer PJ, Van Zyl WH, Isak S, Pretorius IS. 2002. Microbial Cellulose Utilization: Fundamentals and Biotechnology Microbial Cellulose Utilization : Fundamentals and Biotechnology 66.

4. Den Haan R, van Rensburg E, Rose SH, Görgens JF, van Zyl WH. 2014. Progress and challenges in the engineering of non-cellulolytic microorganisms for consolidated bioprocessing. Curr Opin Biotechnol 33C:32-38.

5. Lynd LR, Van Zyl WH, McBride JE, Laser M. 2005. Consolidated bioprocessing of cellulosic biomass: An update. Curr Opin Biotechnol 16:577-583.

6. Celik E, Calık P. 2012. Production of recombinant proteins by yeast cells. Biotechnol Adv 30:1108-18.

7. Idiris A, Tohda H, Kumagai H, Takegawa K. 2010. Engineering of protein secretion in yeast: strategies and impact on protein production. Appl Microbiol Biotechnol 86:403-17.

8. Mellitzer A, Ruth C, Gustafsson C, Welch M, Birner-Grünberger R, Weis R, Purkarthofer T, Glieder A. 2014. Synergistic modular promoter and gene optimization to push cellulase secretion by Pichia pastoris beyond existing benchmarks. J Biotechnol 1-9. 
9. Porro D, Sauer M, Branduardi P, Mattanovich D. 2005. Recombinant Protein Production in Yeasts Recombinant Protein Production in Yeasts 31.

10. Baumann K, Adelantado N, Lang C, Mattanovich D, Ferrer P. 2011. Protein trafficking, ergosterol biosynthesis and membrane physics impact recombinant protein secretion in Pichia pastoris. Microb Cell Fact 10:93.

11. Baumann K, Dato L, Graf AB, Frascotti G, Dragosits M, Porro D, Mattanovich D, Ferrer P, Branduardi P. 2011. The impact of oxygen on the transcriptome of recombinant S. cerevisiae and P. pastoris - a comparative analysis. BMC Genomics 12:218.

12. Zyl WH Van, Riaan RL, John DH. 2007. Consolidated Bioprocessing for Bioethanol Production Using Saccharomyces cerevisiae 205-235.

13. Weber C, Farwick A, Benisch F, Brat D, Dietz H, Subtil T, Boles E. 2010. Trends and challenges in the microbial production of lignocellulosic bioalcohol fuels. Appl Microbiol Biotechnol 87:1303-15.

14. Wimalasena TT, Greetham D, Marvin ME, Liti G, Chandelia Y, Hart A, Louis EJ, Phister TG, Tucker GA, Smart KA. 2014. Phenotypic characterisation of Saccharomyces spp. yeast for tolerance to stresses encountered during fermentation of lignocellulosic residues to produce bioethanol. Microb Cell Fact 13:47.

15. Ruyters S, Mukherjee V, Verstrepen KJ, Thevelein JM, Willems K a, Lievens B. 2014. Assessing the potential of wild yeasts for bioethanol production. J Ind Microbiol Biotechnol 110.

16. Mukherjee V, Steensels J, Lievens B, Van de Voorde I, Verplaetse A, Aerts G, Willems KA, Thevelein JM, Verstrepen KJ, Ruyters S. 2014. Phenotypic evaluation of natural and industrial Saccharomyces yeasts for different traits desirable in industrial bioethanol production. Appl Microbiol Biotechnol.

17. Wohlbach DJ, Rovinskiy N, Lewis JA, Sardi M, Schackwitz WS, Martin JA, Deshpande S, Daum CG, Lipzen A, Sato TK, Gasch AP. 2014. Comparative Genomics of Saccharomyces cerevisiae Natural Isolates for Bioenergy Production. Genome Biol Evol 6:2557-2566.

18. Carreto L, Eiriz MF, Gomes AC, Pereira PM, Schuller D, Santos MAS. 2008. Comparative genomics of wild type yeast strains unveils important genome diversity. BMC Genomics 9:524.

19. Steensels J, Snoek T, Meersman E, Nicolino MP, Voordeckers K, Verstrepen KJ. 2014. Improving industrial yeast strains: exploiting natural and artificial diversity. FEMS Microbiol Rev 1-49.

20. Albers E, Larsson C. 2009. A comparison of stress tolerance in YPD and industrial lignocellulose-based medium among industrial and laboratory yeast strains. J Ind Microbiol Biotechnol 36:1085-91.

21. Den Haan R, van Zyl JM, Harms TM, van Zyl WH. 2013. Modeling the minimum enzymatic requirements for optimal cellulose conversion. Environ Res Lett 8:025013.

22. Cummings C, Fowler T. 1996. Secretion of Trichoderma reesei beta-glucosidase by Saccharomyces cerevisiae. Curr Genet 29:227-33. 
23. Mattanovich D, Gasser B, Hohenblum H, Sauer M. 2004. Stress in recombinant protein producing yeasts 113:121-135.

24. Van Rensburg E, den Haan R, Smith J, van Zyl WH, Görgens JF. 2012. The metabolic burden of cellulase expression by recombinant Saccharomyces cerevisiae Y294 in aerobic batch culture. Appl Microbiol Biotechnol 96:197-209.

25. Hasunuma T, Ishii J, Kondo A. 2015. Rational design and evolutional fine tuning of Saccharomyces cerevisiae for biomass breakdown. Curr Opin Chem Biol 29:1-9.

26. Gurgu L, Lafraya Á, Polaina J, Marín-Navarro J. 2011. Fermentation of cellobiose to ethanol by industrial Saccharomyces strains carrying the $\beta$-glucosidase gene (BGL1) from Saccharomycopsis fibuligera. Bioresour Technol 102:5229-36.

27. De Baetselier A, Vasavada A, Dohet P, Ha-Thi V, De Beukelaer M, Erpicum T, De Clerck L, Hanotier J, Rosenberg S. 1991. Fermentation of a yeast producing A. niger glucose oxidase: scale-up, purification and characterization of the recombinant enzyme. Nat Biotechnol 9:559561.

28. Favaro L, Basaglia M, Trento A, Van Rensburg E, García-Aparicio M, Van Zyl WH, Casella S. 2013. Exploring grape marc as trove for new thermotolerant and inhibitor-tolerant Saccharomyces cerevisiae strains for second-generation bioethanol production. Biotechnol Biofuels 6:168.

29. Mart C, Jönsson LJ. 2003. Comparison of the resistance of industrial and laboratory strains of Saccharomyces and Zygosaccharomyces to lignocellulose-derived fermentation inhibitors 32:386-395.

30. Salvad Z. 2010. Susceptibility and resistance to ethanol in Saccharomyces strains isolated from wild and fermentative environments 1005-1015.

31. Ziv N, Siegal ML, Gresham D. 2013. Genetic and nongenetic determinants of cell growth variation assessed by high-throughput microscopy. Mol Biol Evol 30:2568-2578.

32. Ezov TK, Boger-Nadjar E, Frenkel Z, Katsperovski I, Kemeny S, Nevo E, Korol A, Kashi Y. 2006. Molecular-genetic biodiversity in a natural population of the yeast Saccharomyces cerevisiae from "Evolution Canyon": microsatellite polymorphism, ploidy and controversial sexual status. Genetics 174:1455-68.

33. Boynton PJ, Greig D. 2014. The ecology and evolution of non-domesticated Saccharomyces species. Yeast.

34. Ilmén M, den Haan R, Brevnova E, McBride J, Wiswall E, Froehlich A, Koivula A, Voutilainen SP, Siika-Aho M, la Grange DC, Thorngren N, Ahlgren S, Mellon M, Deleault K, Rajgarhia V, van Zyl WH, Penttilä M. 2011. High level secretion of cellobiohydrolases by Saccharomyces cerevisiae. Biotechnol Biofuels 4:30.

35. Sambrook J and Russel D.W. 1989. Molecular cloning: () 2001. Cold Spring Habor Laboratory Press, Cold Spring Habor, NJ, USA, pp.19-24.

36. La Grange DC, Pretorius IS, van Zyl WH. 1996. Expression of a Trichoderma reesei betaxylanase gene (XYN2) in Saccharomyces cerevisiae. Appl Environ Microbiol 62:1036-1044. 
37. Njokweni a P, Rose SH, van Zyl WH. 2012. Fungal $\beta$-glucosidase expression in Saccharomyces cerevisiae. J Ind Microbiol Biotechnol 39:1445-52.

38. Du Plessis L, Rose SH, van Zyl WH. 2010. Exploring improved endoglucanase expression in Saccharomyces cerevisiae strains. Appl Microbiol Biotechnol 86:1503-11.

39. Hoffman EP, Brown RH, Kunkel LM. 1987. Dystrophin: the protein product of the Duchenne muscular dystrophy locus. Cell 51:919-928.

40. Pandey S, Sree A, Dash SS, Sethi DP. 2013. A novel method for screening beta-glucosidase inhibitors. BMC Microbiol 13:55.

41. Van der Westhuizen TJ, Augustyn OPH, Pretorius IS. 2000. Geographical Distribution of Indigenous Saccharomyces cerevisiae Strains Isolated from Vineyards in the Coastal Regions of the Western Cape in South Africa. South African J Enol Vitic 21:3-9.

42. Jolly NP, Augustyn OHPH, Pretorius IS. 2003. The occurrence of non-Saccharomyces cerevisiae yeast species over three vintages in four vineyards and grape musts from four production regions of the Western Cape, South Africa. South African J Enol Vitic 24:63-69.

43. Blaauw D. 2015. Crossbreeding of natural Saccharomyces cerevisiae strains for enhanced bioethanol production. MSc Thesis. Stellenbosch University.

44. Van Rooyen R, Hahn-Hägerdal B, La Grange DC, van Zyl WH. 2005. Construction of cellobiose-growing and fermenting Saccharomyces cerevisiae strains. J Biotechnol 120:284-95.

45. Kroukamp H, den Haan R, van Wyk N, van Zyl WH. 2013. Overexpression of native PSE1 and SOD1 in Saccharomyces cerevisiae improved heterologous cellulase secretion. Appl Energy 102:150-156.

46. Troy AAH. 2014. A Simplified Method for Measuring Secreted Invertase Activity in Saccharomyces cerevisiae. Biochem Pharmacol Open Access 03.

47. Smart KA, Chambers KM, Lambert I, Jenkins C, Smart CA. 1999. Use of methylene violet staining procedures to determine yeast viability and vitality. J Am Soc Brew Chem 57:18-23.

48. Gerke JP, Chen CTL, Cohen BA. 2006. Natural Isolates of Saccharomyces cerevisiae Display Complex Genetic Variation in Sporulation Efficiency 997:985-997.

49. Ochatt SJ. 2006. Flow cytometry (ploidy determination, cell cycle analysis, DNA content per nucleus). Medicago truncatula Handb 18:1-13.

50. Dumortier H, Lacotte S, Pastorin G, Marega R, Wu W, Bonifazi D, Briand J-P, Prato M, Muller S, Bianco A. 2006. Functionalized carbon nanotubes are non-cytotoxic and preserve the functionality of primary immune cells. Nano Lett 6:1522-1528.

51. Teste M-A, Duquenne M, François JM, Parrou J-L. 2009. Validation of reference genes for quantitative expression analysis by real-time RT-PCR in Saccharomyces cerevisiae. BMC Mol Biol 10:99.

52. Van Zyl JHD, Den Haan R, Van Zyl WH. 2014. Over-expression of native Saccharomyces cerevisiae exocytic SNARE genes increased heterologous cellulase secretion. Appl Microbiol Biotechnol. 
53. Laemmli UK. 1970. Cleavage of structural proteins during the assembly of the head of bacteriophage T4. Nature 227:680-685.

54. Wei H, Wang W, Alahuhta M, Vander Wall T, Baker JO, Taylor LE, Decker SR, Himmel ME, Zhang M. 2014. Engineering towards a complete heterologous cellulase secretome in Yarrowia lipolytica reveals its potential for consolidated bioprocessing. Biotechnol Biofuels 7:148.

55. Kvitek DJ, Will JL, Gasch AP. 2008. Variations in stress sensitivity and genomic expression in diverse $S$. cerevisiae isolates. PLoS Genet 4:e1000223.

56. Warringer J, Zörgö E, Cubillos F a, Zia A, Gjuvsland A, Simpson JT, Forsmark A, Durbin R, Omholt SW, Louis EJ, Liti G, Moses A, Blomberg A. 2011. Trait variation in yeast is defined by population history. PLoS Genet 7:e1002111.

57. Mortimer RK, Johnston JR. 1986. Genealogy of principal strains of the yeast genetic stock center. Genetics 113:35-43.

58. Tang H, Hou J, Shen Y, Xu L, Yang H, Fang X, Bao X. 2013. High $\beta$-glucosidase secretion in Saccharomyces cerevisiae improves the efficiency of cellulase hydrolysis and ethanol production in simultaneous saccharification and fermentation. J Microbiol Biotechnol 23:157785.

59. Van Rooyen R, Hahn-Hägerdal B, La Grange DC, van Zyl WH. 2005. Construction of cellobiose-growing and fermenting Saccharomyces cerevisiae strains. J Biotechnol 120:284-95.

60. McBride JE, Zietsman JJ, Van Zyl WH, Lynd LR. 2005. Utilization of cellobiose by recombinant $\beta$-glucosidase-expressing strains of Saccharomyces cerevisiae: characterization and evaluation of the sufficiency of expression. Enzyme Microb Technol 37:93-101.

61. Kroukamp H. 2015. Improving the protein secretion capacity of Saccharomyces cerevisiae with strain engineering. PhD THesis. Stellenbosch University.

62. Yamada R, Taniguchi N, Tanaka T, Ogino C, Fukuda H, Kondo A. 2010. Cocktail deltaintegration: a novel method to construct cellulolytic enzyme expression ratio-optimized yeast strains. Microb Cell Fact 9:32.

63. Teng D, Xi D, Zhang J, Wang X, Mao R, Zhang Y, Wang J. 2015. Multiple copies of the target gene enhances plectasin secretion in Pichia pastoris X-33. Process Biochem.

64. Yamada R, Tanaka T, Ogino C, Kondo A. 2010. Gene copy number and polyploidy on products formation in yeast. Appl Microbiol Biotechnol 88:849-57.

65. Mansur M, Cabello C, Hernández L, País J, Varas L, Valdés J, Terrero Y, Hidalgo A, Plana L, Besada V, García L, Lamazares E, Castellanos L, Martínez E. 2005. Multiple gene copy number enhances insulin precursor secretion in the yeast Pichia pastoris. Biotechnol Lett 27:339-45.

66. Zhang Z, Moo-Young M, Chisti Y. 1996. Plasmid stability in recombinant Saccharomyces cerevisiae. Biotechnol Adv 14:401-35.

67. Buckholz RG, Gleeson MAG. 1991. Yeast systems for the commercial production of heterologous proteins. Nat Biotechnol 9:1067-1072. 
68. Futcher AB, Cox BS. 1984. Copy number and the stability of 2-um circle-based artificial plasmids of Saccharomyces cerevisiae. J Bacteriol 157:283-290.

69. Kricka W, Fitzpatrick J, Bond U. 2015. Challenges for the Production of Bioethanol from Biomass Using Recombinant YeastsBS:AAM. Elsevier.

70. Liu Z, Tyo KEJ, Martínez JL, Petranovic D, Nielsen J. 2012. Different expression systems for production of recombinant proteins in Saccharomyces cerevisiae. Biotechnol Bioeng 109:1259-68.

71. Hardjito L, Greenfield PF, Lee PL. 1993. Recombinant protein production via fed-batch culture of the yeast Saccharomyces cerevisiae. Enzyme Microb Technol 15:120-126.

72. Verripsab T, Duboc P, Visser C, Sagt C. 2000. From gene to product in yeast: production of fungal cutinase. Enzyme Microb Technol 26:812-818.

73. Ferreira BS, Calado CRC, Van Keulen F, Fonseca LP, Cabral JMS, Da Fonseca MMR. 2003. Towards a cost effective strategy for cutinase production by a recombinant Saccharomyces cerevisiae: strain physiological aspects. Appl Microbiol Biotechnol 61:69-76.

74. Andersen DC, Krummen L. 2002. Recombinant protein expression for therapeutic applications. Curr Opin Biotechnol 13:117-123.

75. Meinander N, Zacchi G, Hahn-Hägerdal B. 1996. A heterologous reductase affects the redox balance of recombinant Saccharomyces cerevisiae. Microbiology 142:165-172.

76. Liu Z, Österlund T, Hou J, Petranovic D, Nielsen J. 2013. Anaerobic $\alpha$-amylase production and secretion with fumarate as the final electron acceptor in Saccharomyces cerevisiae. Appl Environ Microbiol 79:2962-7.

77. Cha HJ, Choi SS, Yoo YJ, Bentley WE. 1997. Enhancement of production of cloned glucoamylase under conditions of low aeration from recombinant yeast using a SUC2 promoter. Process Biochem 32:679-684.

78. Stephanopoulos G. 2007. Challenges in engineering microbes for biofuels production. Science 315:801-4.

79. Bai FW, Anderson WA, Moo-Young M. 2008. Ethanol fermentation technologies from sugar and starch feedstocks. Biotechnol Adv 26:89-105.

80. Liu Z, Liu L, Osterlund T, Hou J, Huang M, Fagerberg L, Petranovic D, Uhlén M, Nielsen J. 2014. Improved Production of a Heterologous Amylase in Yeast by Inverse Metabolic Engineering. Appl Environ Microbiol 46:5542-5550.

81. Aguilar-Uscanga B, Francois JM. 2003. A study of the yeast cell wall composition and structure in response to growth conditions and mode of cultivation. Lett Appl Microbiol 37:268274.

82. Jiménez DJ, Korenblum E, van Elsas JD. 2014. Novel multispecies microbial consortia involved in lignocellulose and 5-hydroxymethylfurfural bioconversion. Appl Microbiol Biotechnol 98:2789-2803. 
83. Öhgren K, Bengtsson O, Gorwa-Grauslund MF, Galbe M, Hahn-Hägerdal B, Zacchi G. 2006. Simultaneous saccharification and co-fermentation of glucose and xylose in steampretreated corn stover at high fiber content with Saccharomyces cerevisiae TMB3400. J Biotechnol 126:488-498.

84. Den Haan R, Rose SH, Lynd LR, van Zyl WH. 2007. Hydrolysis and fermentation of amorphous cellulose by recombinant Saccharomyces cerevisiae. Metab Eng 9:87-94.

85. Wood BE, Ingram LO. 1992. Ethanol production from cellobiose, amorphous cellulose, and crystalline cellulose by recombinant Klebsiella oxytoca containing chromosomally integrated Zymomonas mobilis genes for ethanol production and plasmids expressing thermostable cellulase genes fr. Appl Environ Microbiol 58:2103-10.

86. Yamada R, Nakatani Y, Ogino C, Kondo A. 2013. Efficient direct ethanol production from cellulose by cellulase- and cellodextrin transporter-co-expressing Saccharomyces cerevisiae. AMB Express 3:34.

87. Medve J, Karlsson J, Lee D, Tjerneld F. 1998. Hydrolysis of microcrystalline cellulose by cellobiohydrolase I and endoglucanase II from Trichoderma reesei: adsorption, sugar production pattern, and synergism of the enzymes. Biotechnol Bioeng 59:621-634.

88. Remize F, Roustan JL, Sablayrolles JM, Barre P. 1999. Glycerol Overproduction by Engineered Saccharomyces cerevisiae Wine Yeast Strains Leads to Substantial Changes in ByProduct Formation and to a Stimulation of Fermentation Rate in Stationary Phase 65:143-149.

89. Shock TR, Thompson J, Yates JR, Madhani HD. 2009. Hog1 mitogen-activated protein kinase (MAPK) interrupts signal transduction between the Kss1 MAPK and the Tec1 transcription factor to maintain pathway specificity. Eukaryot Cell 8:606-16.

90. Dinh TN, Nagahisa K, Hirasawa T, Furusawa C, Shimizu H. 2008. Adaptation of Saccharomyces cerevisiae cells to high ethanol concentration and changes in fatty acid composition of membrane and cell size. PLoS One $\mathbf{3}$.

91. Landaeta R, Aroca G, Acevedo F, Teixeira JA, Mussatto SI. 2013. Adaptation of a flocculent Saccharomyces cerevisiae strain to lignocellulosic inhibitors by cell recycle batch fermentation. Appl Energy 102:124-130.

92. Basso LC, de Amorim HV, de Oliveira AJ, Lopes ML. 2008. Yeast selection for fuel ethanol production in Brazil. FEMS Yeast Res 8:1155-63.

93. Garay-Arroyo A, Covarrubias AA, Clark I, Niño I, Gosset G, Martinez A. 2004. Response to different environmental stress conditions of industrial and laboratory Saccharomyces cerevisiae strains. Appl Microbiol Biotechnol 63:734-41.

94. Kumari R, Pramanik K. 2012. Improvement of multiple stress tolerance in yeast strain by sequential mutagenesis for enhanced bioethanol production. J Biosci Bioeng 114:622-9.

95. Ramos CL, Duarte WF, Freire AL, Dias DR, Cristina E, Eleutherio A, Schwan RF. 2013. Evaluation of stress tolerance and fermentative behavior of indigenous Saccharomyces cerevisiae 944:935-944.

96. Zheng YL, Wang SA. 2015. Stress Tolerance Variations in Saccharomyces cerevisiae Strains from Diverse Ecological Sources and Geographical Locations. PLoS One 10:e133889. 
97. Stanley D, Bandara A, Fraser S, Chambers PJ, Stanley GA. 2010. The ethanol stress response and ethanol tolerance of Saccharomyces cerevisiae. J Appl Microbiol 109:13-24.

98. Carreto L, Eiriz MF, Domingues I, Schuller D, Moura GR, Santos M a S. 2011. Expression variability of co-regulated genes differentiates Saccharomyces cerevisiae strains. BMC Genomics 12:201.

99. Cavalieri D, Townsend JP, Hartl DL. 2000. Manifold anomalies in gene expression in a vineyard isolate of Saccharomyces cerevisiae revealed by DNA microarray analysis. Proc Natl Acad Sci U S A 97:12369-74.

100. Fay JC, Mccullough HL, Sniegowski PD, Eisen MB. 2004. Population genetic variation in gene expression is associated with phenotypic variation in Saccharomyces cerevisiae 1-14.

101. Gasch AP, Werner-Washburne M. 2002. The genomics of yeast responses to environmental stress and starvation. Funct Integr Genomics 2:181-192.

102. Gasch AP. 2003. The environmental stress response: a common yeast response to diverse environmental stresses, p. 11-70. In Yeast stress responses. Springer.

103. Causton HC, Ren B, Koh SS, Harbison CT, Kanin E, Jennings EG, Lee TI, True HL, Lander ES, Young R a. 2001. Remodeling of yeast genome expression in response to environmental changes. Mol Biol Cell 12:323-37.

104. Thorsen M, Perrone GG, Kristiansson E, Traini M, Ye T, Dawes IW, Nerman O, Tamás MJ. 2009. Genetic basis of arsenite and cadmium tolerance in Saccharomyces cerevisiae. BMC Genomics 10:105.

105. Schalén TM. 2015. Monitoring and control of protein production in fungi. Doctoral dissertation, Technical University of Denmark (Danmarks Tekniske Universitet), Department of Systems Biology.Institut for Systembiologi.

106. Bull VH, Thiede B. 2012. Proteome analysis of tunicamycin-induced ER stress. Electrophoresis 33:1814-23.

107. Kanik-ennulat C, Montalvo E, Neff N. 1995. Sodium Orthovanadate-Resistant Mutants of. In Vivo. Genetics 140, no. 3: 933-943.

108. Serrano R, Martin H, Casamayor A, Arino J. 2006. Signaling Alkaline pH Stress in the Yeast Saccharomyces cerevisiae through the Wsc1 Cell Surface Sensor and the Slt2 MAPK Pathway. J Biol Chem 281:39785-39795.

109. Ram AFJ, Klis FM. 2006. Identification of fungal cell wall mutants using susceptibility assays based on Calcofluor white and Congo red. Nat Protoc 1:2253-2256.

110. Yin QY, de Groot PWJ, Dekker HL, de Jong L, Klis FM, de Koster CG. 2005. Comprehensive proteomic analysis of Saccharomyces cerevisiae cell walls identification of proteins covalently attached via glycosylphosphatidylinositol remnants or mild alkali-sensitive linkages. J Biol Chem 280:20894-20901.

111. Krysan DJ. 2009. The cell wall and endoplasmic reticulum stress responses are coordinately regulated in Saccharomyces cerevisiae. Commun Integr Biol 2:233-5. 
112. Bartkeviciute D, Sasnauskas K. 2003. Studies of yeast Kluyveromyces lactis mutations conferring super-secretion of recombinant proteins. Yeast 20:1-11.

113. Bartkeviciūte D, Sasnauskas K. 2004. Disruption of the MNN10 gene enhances protein secretion in Kluyveromyces lactis and Saccharomyces cerevisiae. FEMS Yeast Res 4:833-40.

114. Hou J, Osterlund T, Liu Z, Petranovic D, Nielsen J. 2013. Heat shock response improves heterologous protein secretion in Saccharomyces cerevisiae. Appl Microbiol Biotechnol 97:3559-68.

115. Schröder M,. 2006. The unfolded protein response. Mol Biotechnol 34:279-290. 
Chapter 4:

General Discussion and Conclusions 


\subsection{General discussion}

In South Africa, lignocellulosic biomass is an attractive source of fermentable sugars for the conversion to bioethanol since it is inexpensive, abundant, financially viable and can be balanced with adequate food production (1). One of the current aims of research into using cellulosic biomass for the production of bioethanol is the creation of microorganisms capable of degrading cellulose into monomeric sugars which can be fermented into alcohols at high rates and yields (CBP) $(2,3)$. Due to its long history associated with fermentation, S. cerevisiae is one of the microorganisms of choice for second generation $(2 \mathrm{G})$ bioethanol production (3). It is especially useful in first generation $(1 \mathrm{G})$ bioethanol production due to its high ethanol yields and ethanol tolerance (3). Important challenges regarding different aspects that affect the performance of the $S$. cerevisiae during biomass processing still need to be overcome (4). The aim of the work presented in this thesis was to identify natural $S$. cerevisiae strains with high heterologous cellulase activity (total and secreted cell specific activities) and high tolerance to inhibitors (hydrolysate-derived and other environmental stresses). Therefore, the natural diversity of yeast was exploited to identify $S$. cerevisiae strains with innate high tolerance to a variety of bioethanol-specific stresses e.g., high ethanol concentrations, high temperatures, fluctuating osmolarity and other inhibitors found in lignocellulosic hydrolysates etc. (5).

As outlined in Chapter 2, the fermentation environment in $2 \mathrm{G}$ bioethanol production differs greatly from other classical industrial fermentations. A major challenge for the cellulosic bioethanol industry is to extract fermentable sugars from biomass in a cost-effective manner (6). Lignocellulose accounts for $50 \%$ of the world's biomass (50 billion ton per annum) and is composed of cellulose, hemi-cellulose and lignin (7). Cellulose can be hydrolysed to glucose monomer components by the action of cellulolytic enzymes (8). The heterologous expression of these cellulase genes has mainly been limited to laboratory and commercial S. cerevisiae strains (9-13). The main aim of this study was to exploit the natural biodiversity of $S$. cerevisiae in order to find strains with combined desirable characteristics for CBP. Although the focus of this study was to evaluate natural strains based on phenotypic data such as cell specific cellulase activity levels (Section 3.3.1-3.3.2), fermentation profiles (Section 3.3.6-3.3.7) and tolerance to environmental stresses (Section 3.3.8), strains were also investigated to understand the physiological and phenotypical background of host strain which may contribute to recombinant protein secretion efficiency (Section 3.3.3-3.3.5 and 3.3.8). 


\subsubsection{Differential heterologous cellulase activity}

To expand the concept of strain variation, we assessed the expression of heterologous genes encoding key cellulolytic enzymes in natural S. cerevisiae strains. Episomally produced S.f.Cel3A activity was achieved in all 34 strains evaluated in a preliminary screening, demonstrating differential total and secreted activity between the natural strains and reference strains (Section 3.3.1). In accordance with Gurgu et al. (14), we observed variation in cell wall retention levels between the strains, with a general trend of reference strains releasing less of the S.f.Cel3A activity into the media than the natural strains. Although protein determination analyses were performed, the results based on a visual analysis of a stained SDS PAGE gels were inconclusive. Strategies including (i) column filtration methods (size exclusion) and (ii) freeze dry techniques were attempted to purify and concentrate the protein yields. However, in all cases, the native proteins interfered with protein determination. Future studies should quantify protein yields using alternative methods including Western blotting, Enzyme-linked immunosorbent assay (ELISA), fusion proteins such as His-tagged recombinant proteins or differential scanning fluorimetry (DSF) (15).

The multi-tolerant YI13 strain is superior to the reference strain S288c and other transformants with respect to secreted cell specific activity levels of EGII (T.r.Cel5A) and CBHI (T.e.Cel7A) (Section 3.3.2), whilst the natural strain FIN1 outperforming the YI13 strain with regards to BGLI (S.f.Cel3A) secreted cell specific activity in aerated (Section 3.3.1) and oxygen-limited conditions (Section 3.3.6). The YI59 strain outperformed all the other strains in terms of endogenous invertase activity levels (3.06 U/mg DCW) (Section 3.3.2). Similar to invertase activity, we suspect that secreted heterologous cellulolytic activity levels is highly strain-specific, with differential activity levels dependent on the genetic background of the host strain. This result reveals a compatibility factor in terms of the properties of the protein itself and the host, which influences the cell-specific activity levels.

Natural strain YI13 and reference strain S288c demonstrate different capacities for respiratory and fermentative growth, which could affect fitness in bioethanol production environments (Section 3.3.4). While no significant differences in growth rates between the transformants of natural YI13 and reference S288c were found (with the exception of YI13[Cel5A]), it was noted that natural YI13 transformants grew to significantly higher cell biomass densities in YPD than the reference S288c transformants. We used optical density as a proxy for cell density, thus differences in cell size were not measured and could also have obscured 
differences in cell density (16). A further step in this study would be to analyse the effect of cell size on heterologous enzyme production and secretion.

In addition, another aim of the work was to investigate whether differential enzyme activity was due to differences in ploidy and/or gene copy number. In general, it has been suggested that increased enzyme activity correlates with the DNA content of yeast cells, with diploid states having higher levels compared to haploid states, and even greater levels produced in tetraploid species (17). However, similar ploidy states and low variation in plasmid copy numbers were observed between the superior transformants and reference strains. All natural strain transformants are confirmed diploid (Section 3.3.4) with little variation in plasmid copy number being observed between all transformants (Section 3.3.3). Further studies are needed to evaluate protein yields between the transformants in order to confirm whether this differential activity is due to higher protein yields or due to other factors. A second option is studying the characteristics of the secreted recombinant proteins. Techniques such as using circular dichroism can determine changes in the secondary structure and folding properties of the secreted proteins (18). Determining the level of glycosylation of the secreted proteins between strains is another important feature known to influence secretion titers and enzyme activity (19).

To determine if natural and reference strains differ in their growth and fermentation characteristics, we selected six natural transformants based on promising secreted activity levels and high tolerance to environmental stresses, and simulated classical fermentation (with $2 \%$ glucose) and co-culture fermentations (using 2\% Avicel cellulose) (Section 3.3.5-3.3.6). The results from this study indicate that the natural strain YI13 compares favourably in terms of ethanol titers to the industrial benchmark MH1000 strain in a classical fermentation environment at $30^{\circ} \mathrm{C}$. While the FIN1 strain yields the lowest biomass and consumed glucose slowly compared to the rest of the strains, it is demonstrated that this strain may be inhibited by rising ethanol concentrations due to its low tolerance to ethanol (as shown in the stress plate assays). Co-fermentation of superior and reference $S$. cerevisiae transformants resulted in hydrolysis of Avicel cellulose and the end products were identified with HPLC. The YI13 co-culture fermentations resulted in statistically significantly higher ethanol titers compared to reference S288c co-culture fermentations. Overall, moderate levels of cellobiose were detected, albeit low ethanol yields were also produced suggesting ineffective T.e.Cel7A or T.r.Cel5A activity 


\subsubsection{Tolerance to environmental and metabolic stresses}

It was previously noted that microorganisms that produce a compound of interest most efficiently (i.e. with the highest productivity, titer and yield from cellulose, etc.) are rarely also highly tolerant to acid, heat or similar environmental stresses (88). Since tolerance to environmental stresses is a polygenic trait $(20,21)$, dictated by the expression of multiple native genes it is usually very difficult to insert this phenotype into a desirable host strain, therefore using a strain with innate tolerance to fermentation stress is a good starting point for this project.

As discussed previously in Chapter 2, stress responses in yeast can derive from metabolic interferences or from unfavourable environmental conditions. It has been a common aim to engineer metabolic stress response such as the UPR to improve protein folding and secretion, while this targeted interference for environmental stress response is limited (22). Not much information exists on engineering the host cells to improve their robustness against environmental stresses. As suggested by Mattanovich et al. (22) the "environmental stress responses of yeasts turned out to be highly interrelated, and even connected to metabolic stress reactions". Interestingly, an intact secretory pathway is important for the cell to withstand many different environmental conditions since the secretory pathway is implicated in many important processes such as lipid biosynthesis, protein targeting and secretion, as well as the unfolded protein response (23). In some cases, alterations to the secretion pathway lead to sensitivity to environmental stresses e.g., H. polymorpha strain carrying a disrupted pmt gene secreted high amounts $N$-glycosylated proteins, however showed temperature sensitivity due to a cell wall integrity defect . Other studies have demonstrated that mutations impairing proper functioning of the secretory pathway can cause sensitivity to a broad range of treatments and growth conditions. In this study, we evaluated natural strains based on heterologous cellulase activity levels (Section 3.3.1-3.3.7) and tolerance to various industrial stresses (3.3.8).

To test for phenotypic differentiation between tolerance capabilities of $S$. cerevisiae strains we simulated the stresses that the strains would be exposed to under bioethanol production conditions (e.g., $\mathrm{NaCl}$, ethanol, and temperature stresses and inhibitors produced during lignocellulose hydrolysis) (Section 3.3.8). Since it has become clear that metabolic and environmental stresses impact recombinant protein production and secretion $(22,26)$, the innate tolerance capabilities of strains was determined for not only environmental stresses, but cell wall, secretion and ER stresses as well (Section 3.3.8). 
A wide variability of responses to the different environmental stress conditions was detected and no general rules could be assumed for different S. cerevisiae strains. Collectively, the strains showed the greatest variation between tunicamycin, sodium orthovanadate, inhibitor resistance and ethanol tolerance, implying these stressors are not generally experienced by yeast, as suggested by Kvitek et al. (27). It was also noted that the effect of genetic manipulation did not alter the innate tolerance capabilities of the strains. Nonetheless, these results indicated that selected environmental strains were better equipped to survive conditions found in the industrial environment, including growth in the presence of multiple stresses associated with bioethanol production. Based on the results of our work, we can confirm the versatility of natural strains as a research platform for studies in bioethanol production

Significant differences were found in cell wall integrity and in tolerance to ethanol and temperatures between reference strains and natural strains suggesting possible differences in lipid composition, which may correlate to changes at the genome level in the different genes involved in lipid transport, synthesis, and other steps of lipid metabolism $(28,29)$. This indicates that alterations in membrane composition may be behind the improved combined tolerance and heterologous activity levels $(30,31)$. Although this study focuses on evaluating and identifying strains with high general secretion phenotypes by expressing individual cellulase genes relevant for $2 \mathrm{G}$ cellulosic ethanol production, our results also suggest the involvement of tolerance to secretion stresses and cell wall stress in the superior secreted cellulolytic activity levels.

Variations in tolerances to secretion, endoplasmic reticulum and cell wall stressors (Section 3.3.7) have strengthened the hypothesis that the genetic background of a strain contributes to higher secreted activity levels. The multi-tolerant YI13 strain demonstrated high tolerance to temperatures $\left(37^{\circ} \mathrm{C}\right.$ and $\left.40^{\circ} \mathrm{C}\right)$, high ethanol concentrations $(10 \% \mathrm{w} / \mathrm{v})$ and high concentrations of hydrolysate inhibitor cocktail (up to $50 \%$ ), as well as high to moderate tolerances to ER stressors tunicamycin, DTT and vanadate, and cell wall stressor Congo Red. Since adaptation to a stress is known to confer cross-resistance to other stresses (26) it is not surprising to find multi-tolerant strains and this warrants further investigation into utilising this phenomenon for improving heterologous protein production. The robust strain YI13 displaying higher secreted cell specific activities for T.r.Cel5A and T.e.Cel7A, suggesting that it may have better protein folding capabilities, allowing the strain to have better secretion of heterologous cellulases, as well as tolerance to other stress conditions. This suggested the possibility that the strains were partially selected for by the environmental conditions. The pursuit of selection of yeast strains 
showing increased enzyme production (Section 3.3.1-3.3.7), coupled with high tolerance to industrial stressors (Section 3.3.8), may contribute to the knowledge required for the on-going development of consolidated bio-processing of cellulosic biomass and inform further attempts to determine the optimal process operating windows.

\subsection{Conclusions}

The overall aim of this study was to investigate desirable characteristics of natural S. cerevisiae strains in comparison to reference commercial and laboratory strains. This was in order to identify strains that could be useful in the further development of heterologous hosts for the degradation of cellulose-based biomass and its conversion into bioethanol. Several conclusions can be drawn from the results and several suggestions can be made for future studies.

The general aims of this study were met as follows:

(i) We evaluated and identified natural S. cerevisiae strains demonstrating superior cell specific recombinant enzyme activities when producing key cellulolytic enzymes.

(ii) We compared natural, industrial and laboratory strains for desirable bioethanol production features, and identified natural strains which produce high ethanol titers and have innately high tolerance to various industrial stressors, including inhibitors found in lignocellulosic hydrolysates.

(iii) We obtained natural strains with similar characteristics when comparing to common industrial and laboratory strains. The natural strains contain characteristics suited for the biofuels industry, thereby extending the number of strains available to distilleries and bio-refineries.

To summarise, the following could be concluded from this study:

- Expression of S.f.cel3A gene led to differential secreted and total cell specific activity levels between natural strains and reference strains, as well as differences in cell wall retention levels.

- The natural strain FIN1 demonstrated significantly higher recombinant S.f.Cel3A secreted and total activity levels compared to reference strains MH1000, Hoeg, S288c and Y294 and compared to other natural strains.

- Growth rate was suggested to be a factor in high S.f.Cel3A activity levels. 
- Natural strain YI13 displayed the highest specific activity for recombinant T.r.Cel5A and T.e.Cel7A, however had only moderate activity for S.f.Cel3A, suggesting a compatibility factor in terms specific heterologous enzymes between hosts.

- Expression of three important cellulase genes, namely S.f.cel3A, T.r.cel5A and T.e.cel7A demonstrated a protein-specific nature of secretion capacity between strains.

- Furthermore, inherent genetic backgrounds appeared to influence activity levels.

- Ploidy states of the natural strains were confirmed diploid, therefore variation in ploidy was not a factor in secreted activity levels for this study.

- Low variation in plasmid copy number was observed; therefore copy number was not a significant determining factor in secreted activity levels for this study.

- Differences in S.f.Cel3A cell specific activity levels were observed between anaerobic vs. aerobic cultivation.

- Natural strain YI13 demonstrated multi-tolerance to industrial stressors and secretion stress.

- Cell wall integrity may play a role in cellulase activity levels.

In this study we have identified strains with higher secretion compared to reference strains of each of the major cellulase groups required for crystalline cellulose utilization, which represents a step towards realising a cost effective second generation biofuel production.

\subsection{Future prospectives}

Current methods for hydrolysis and fermentation of lignocellulosic substrates are still inefficient and expensive $(32,33)$, therefore further research surmounting the challenges around issues of inhibition of hydrolysis by cellulases, improvements in enzyme yields and elimination of inhibitor by-products are needed. Although major milestone studies have achieved the development of microorganisms with the ability to utilise lignocellulosic substrates and produce ethanol $(34,35)$, a great deal of research needs to be conducted in an attempt to produce an effective, ideal host for CBP.

Further studies are needed to expand the potential host range for heterologous gene expression. For example, Fitzpatrick et al. (36) demonstrated up to 10-fold higher production yields of cellulolytic enzyme activity in polyploid $S$. pastorianus compared to $S$. cerevisiae. Further studies should focus on optimising cellulase cocktail mixtures produced by the host microorganisms, to achieve an effective synergistic action, resulting in less externally added 
enzymes being required (2). The limiting activity of BGL results in a bottleneck in cellulose hydrolysis (14), therefore further improvement in terms of BGL production and secretion is needed. Cell wall studies are needed to determine the extent to which BGL is retained in the periplasmic space and the retention levels between the strains.

In recent years, the advances in the field of genomics, transcriptomics and proteomics has allowed researchers to more accurately study pathways involved in tolerance to environmental stresses and secretion of a desired product (37). This study initiates future studies in reverse engineering, also known as 'inverse metabolic engineering' or 'reverse metabolic engineering', is defined as a cycle of steps aimed at identifying the molecular mechanisms behind a phenotype of interest (Figure 4.1) (37). Phenotypes can be selected by screening from targeted environments or from collections (such as the ones discussed in Chapter 3).

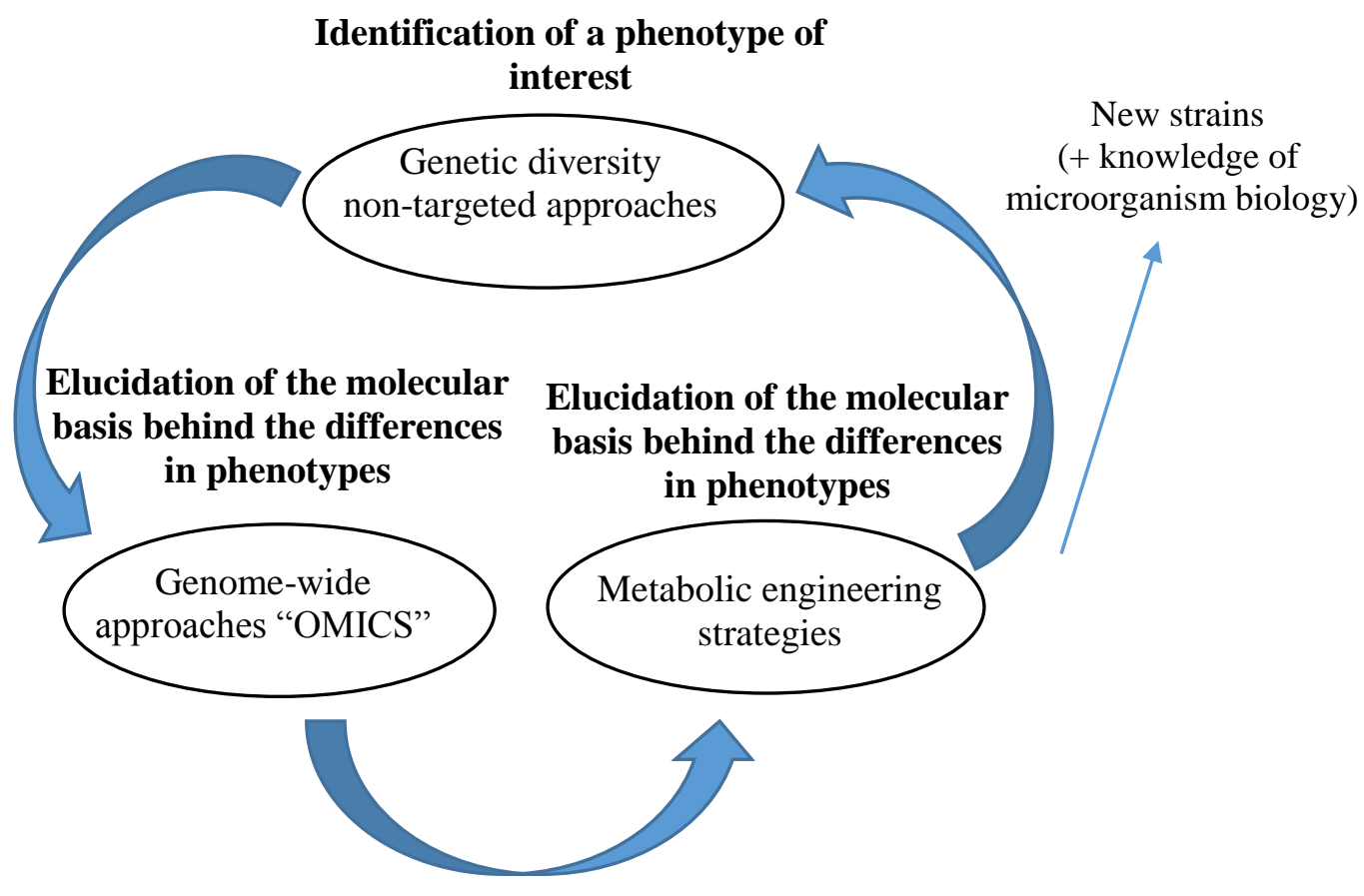

Figure 4.1. Simplified scheme for the reverse metabolic engineering cycle and (encircled) approaches used at each step of the cycle. Image adapted from Salinas et al. (37).

Although classical breeding is not generally considered as strain engineering, the principle of adding valuable factors to the desired host strain is still relevant and can be used in future prospects. This strategy has the advantage of transferring multiple (potentially interdependent) genetic elements at once, as well as adding additional levels of variation, by introducing gene allele variations. The potential allelic differences between different strains of a potential CBP 
host are valuable and rarely explored as a source of genetic tools for future engineering strategies (38). Using approaches such as segregation frequencies and whole genome sequencing (such as quantitative trait loci analysis [QTL]), polygenic beneficial alleles can be identified simultaneously and can explain inter-strain phenotypic diversity arising from subtle alterations in gene sequences $(21,39-41)$. The use of segregation frequencies is highly dependent on the availability of a large strain collections with phenotypic variations between strains (such as tolerance to environmental stresses or secretion of recombinant proteins as done in this study) and accurate high throughput screening methods.

Ultimately, future research aims would be to develop a robust bioconversion system, which will involve identifying and overcoming the major conversion restrictions of product inhibition, temperature and $\mathrm{pH}$ tolerances (33). According to the 2015 U.S. Department of Energy's “Bioenergy Workshop: Lignocellulosic Biomass for Advanced Biofuels and Bio-products" (42) the following requirements are needed for the development of a future costeffective biomass-to-ethanol process:

- High ethanol yields (>95\% of the theoretical yield) with efficient C6 and C5 sugar consumption, minimal inhibitor formation, and minimal loss of carbon into cell biomass.

- Hosts to produce high titers of recombinant cellulolytic enzymes (20 g/L).

- Final ethanol titers (10-15 wt \%).

- Ethanol productivity high aerated and anaerobic conditions $(2.5 \mathrm{~g} / \mathrm{l} / \mathrm{h})$.

- Development of robust microbes for hosts in CBP.

- Tolerance to the inhibitory compounds present in hydrolysates which are toxic to microbes and inhibit enzymes.

In conclusion, both industry and fundamental research fields need a cooperative research effort to achieve the above targets. The identification and construction of a microorganism with the ability to grow in inhibitory environments of high ethanol and inhibitor concentrations, whilst producing high yields of cellulase enzymes in order to eventually produce bioethanol remains a priority in order to create an efficient CBP process. 


\subsection{References}

1. Von Grebmer K, Ringler C, Rosegrant MW, Olofinbiyi T, Wiesmann D, Fritschel H, Badiane O, Torero M, Yohannes Y. 2012. 2012 Global hunger index: the challenge of hunger: Ensuring sustainable food security under land, water, and energy stresses. Intl Food Policy Res Inst.

2. Fujita Y, Ito J, Ueda M, Fukuda H, Kondo A. 2004. Synergistic Saccharification, and Direct Fermentation to Ethanol, of Amorphous Cellulose by Use of an Engineered Yeast Strain Codisplaying Three Types of Cellulolytic Enzyme 70:1207-1212.

3. van Zyl WH, Lynd LR, den Haan R. and McBride JE. 2007. Consolidated bioprocessing for bioethanol production using Saccharomyces cerevisiae. In Biofuels .205-235. Springer Berlin Heidelberg.

4. Stephanopoulos G. 2007. Challenges in engineering microbes for biofuels production. Science 315:801-4.

5. Weber C, Farwick A, Benisch F, Brat D, Dietz H, Subtil T, Boles E. 2010. Trends and challenges in the microbial production of lignocellulosic bioalcohol fuels. Appl Microbiol Biotechnol 87:1303-15.

6. Hall M, Bansal P, Lee JH, Realff MJ, Bommarius AS. 2010. Cellulose crystallinity - A key predictor of the enzymatic hydrolysis rate. FEBS J 277:1571-1582.

7. Kang Q, Appels L, Tan T, Dewil R. 2014. Bioethanol from Lignocellulosic Biomass : Current Findings Determine Research Priorities 2014.

8. Wilson DB. 2009. Cellulases and biofuels. Curr Opin Biotechnol 20:295-9.

9. Pizarro FJ, Jewett MC, Nielsen J, Agosin E. 2008. Growth temperature exerts differential physiological and transcriptional responses in laboratory and wine strains of Saccharomyces cerevisiae. Appl Environ Microbiol 74:6358-68.

10. Garay-Arroyo A, Covarrubias AA, Clark I, Niño I, Gosset G, Martinez A. 2004. Response to different environmental stress conditions of industrial and laboratory Saccharomyces cerevisiae strains. Appl Microbiol Biotechnol 63:734-41.

11. Albers E, Larsson C. 2009. A comparison of stress tolerance in YPD and industrial lignocellulose-based medium among industrial and laboratory yeast strains. J Ind Microbiol Biotechnol 36:1085-91.

12. Mart C, Jönsson LJ. 2003. Comparison of the resistance of industrial and laboratory strains of Saccharomyces and Zygosaccharomyces to lignocellulose-derived fermentation inhibitors 32:386-395.

13. Pereira FB, Romaní A, Ruiz HA, Teixeira JA, Domingues L. 2014. Industrial robust yeast isolates with great potential for fermentation of lignocellulosic biomass. Bioresour Technol 161:192-9.

14. Gurgu L, Lafraya Á, Polaina J, Marín-Navarro J. 2011. Fermentation of cellobiose to ethanol by industrial Saccharomyces strains carrying the $\beta$-glucosidase gene (BGL1) from Saccharomycopsis fibuligera. Bioresour Technol 102:5229-36. 
15. Seo D-H, Jung J-H, Kim H-Y, Park C-S. 2014. Direct and simple detection of recombinant proteins from cell lysates using differential scanning fluorimetry. Anal Biochem 444:75-80.

16. Smith C, Pomiankowski A, Greig D. 2014. Size and competitive mating success in the yeast Saccharomyces cerevisiae. Behav Ecol 25:320-327.

17. Kricka W, Fitzpatrick J, Bond U. 2014. Metabolic engineering of yeasts by heterologous enzyme production for degradation of cellulose and hemicellulose from biomass: A perspective. Front Microbiol 5:1-11.

18. Greenfield NJ. 2006. Using circular dichroism spectra to estimate protein secondary structure. Nat Protoc 1:2876-2890.

19. Kruszewska JS, Perlińska-lenart U, Górka-nieć W, Orłowski J, Zembek P, Palamarczyk G. 2008. Alterations in protein secretion caused by metabolic engineering of glycosylation pathways in fungi 55:447-456.

20. Cubillos F A, Billi E, ZÖrgÖ E, Parts L, Fargier P, Omholt S, Blomberg A, Warringer J, Louis EJ, Liti G. 2011. Assessing the complex architecture of polygenic traits in diverged yeast populations. Mol Ecol 20:1401-1413.

21. Yang Y, Foulquié-Moreno MR, Clement L, Erdei É, Tanghe A, Schaerlaekens K, Dumortier F, Thevelein JM. 2013. QTL Analysis of High Thermotolerance with Superior and Downgraded Parental Yeast Strains Reveals New Minor QTLs and Converges on Novel Causative Alleles Involved in RNA Processing. PLoS Genet 9.

22. Mattanovich D, Gasser B, Hohenblum H, Sauer M. 2004. Stress in recombinant protein producing yeasts. J Biotechnol 113:121-35.

23. Thorsen M, Perrone GG, Kristiansson E, Traini M, Ye T, Dawes IW, Nerman O, Tamás MJ. 2009. Genetic basis of arsenite and cadmium tolerance in Saccharomyces cerevisiae. BMC Genomics 10:105.

24. Dudley AM, Janse DM, Tanay A, Shamir R, Church GM. 2005. A global view of pleiotropy and phenotypically derived gene function in yeast. Mol Syst Biol $\mathbf{1}$.

25. Hillenmeyer ME, Fung E, Wildenhain J, Pierce SE, Hoon S, Lee W, Proctor M, Onge RPS, Tyers M, Koller D. 2008. The chemical genomic portrait of yeast: uncovering a phenotype for all genes. Science (80- ) 320:362-365.

26. Gasch AP. 2003. The environmental stress response: a common yeast response to diverse environmental stresses, p. 11-70. In Yeast stress responses. Springer.

27. Kvitek DJ, Will JL, Gasch AP. 2008. Variations in stress sensitivity and genomic expression in diverse S. cerevisiae isolates. PLoS Genet 4:e1000223.

28. Aguilar-Uscanga B, Francois JM. 2003. A study of the yeast cell wall composition and structure in response to growth conditions and mode of cultivation. Lett Appl Microbiol 37:268274.

29. Krysan DJ. 2009. The cell wall and endoplasmic reticulum stress responses are coordinately regulated in Saccharomyces cerevisiae. Commun Integr Biol 2:233-5. 
30. Bartkeviciūte D, Sasnauskas K. 2004. Disruption of the MNN10 gene enhances protein secretion in Kluyveromyces lactis and Saccharomyces cerevisiae. FEMS Yeast Res 4:833-40.

31. Yin QY, de Groot PWJ, Dekker HL, de Jong L, Klis FM, de Koster CG. 2005. Comprehensive proteomic analysis of Saccharomyces cerevisiae cell walls identification of proteins covalently attached via glycosylphosphatidylinositol remnants or mild alkali-sensitive linkages. J Biol Chem 280:20894-20901.

32. Menon V, Rao M. 2012. Trends in bioconversion of lignocellulose: Biofuels, platform chemicals \& biorefinery concept. Prog Energy Combust Sci 38:522-550.

33. Kricka W, Fitzpatrick J, Bond U. 2015. Challenges for the Production of Bioethanol from Biomass Using Recombinant YeastsBS:AAM. Elsevier.

34. Den Haan R, Rose SH, Lynd LR, van Zyl WH. 2007. Hydrolysis and fermentation of amorphous cellulose by recombinant Saccharomyces cerevisiae. Metab Eng 9:87-94.

35. Yamada R, Nakatani Y, Ogino C, Kondo A. 2013. Efficient direct ethanol production from cellulose by cellulase- and cellodextrin transporter-co-expressing Saccharomyces cerevisiae. AMB Express 3:34.

36. Fitzpatrick J, Kricka W, James TC, Bond U. 2014. Expression of three Trichoderma reesei cellulase genes in Saccharomyces pastorianus for the development of a two-step process of hydrolysis and fermentation of cellulose. J Appl Microbiol 117:96-108.

37. Parts L, Cubillos F A, Warringer J, Jain K, Salinas F, Bumpstead SJ, Molin M, Zia A, Simpson JT, Quail M a., Moses A, Louis EJ, Durbin R, Liti G. 2011. Revealing the genetic structure of a trait by sequencing a population under selection. Genome Res 21:1131-1138.

38. Swinnen S, Thevelein JM, Nevoigt E. 2012. Genetic mapping of quantitative phenotypic traits in Saccharomyces cerevisiae. FEMS Yeast Res 12:215-227.

39. Katou T, Namise M, Kitagaki H, Akao T, Shimoi H. 2009. QTL mapping of sake brewing characteristics of yeast. J Biosci Bioeng 107:383-393.

40. Marullo P, Aigle M, Bely M, Masneuf-Pomarède I, Durrens P, Dubourdieu D, Yvert G. 2007. Single QTL mapping and nucleotide-level resolution of a physiologic trait in wine Saccharomyces cerevisiae strains. FEMS Yeast Res 7:941-52.

41. Nogami S, Ohya Y, Yvert G. 2007. Genetic complexity and quantitative trait loci mapping of yeast morphological traits. PLoS Genet 3:e31.

42. 2015 U.S. Department of Energy. 2015. Bioenergy Workshop: Lignocellulosic Biomass for Advanced Biofuels and Bio-products. 
Chapter 5:

Addendum 


\subsection{Results and supplementary data not included in previous chapters}

\subsubsection{Empty vector constructions}

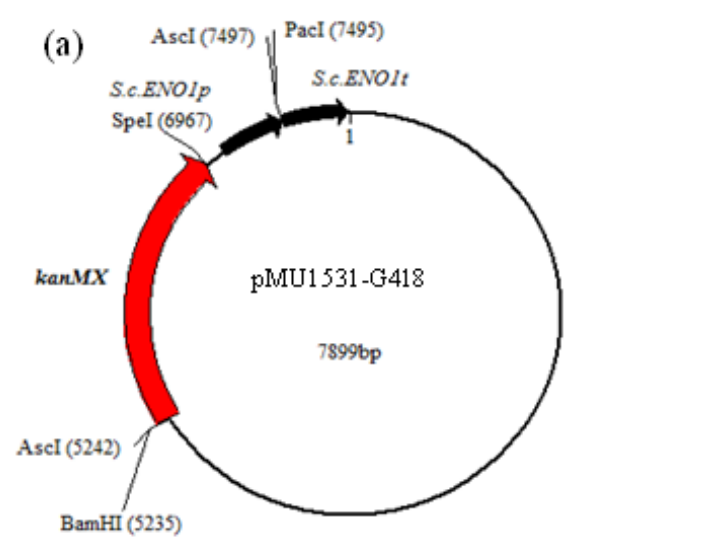

(b)

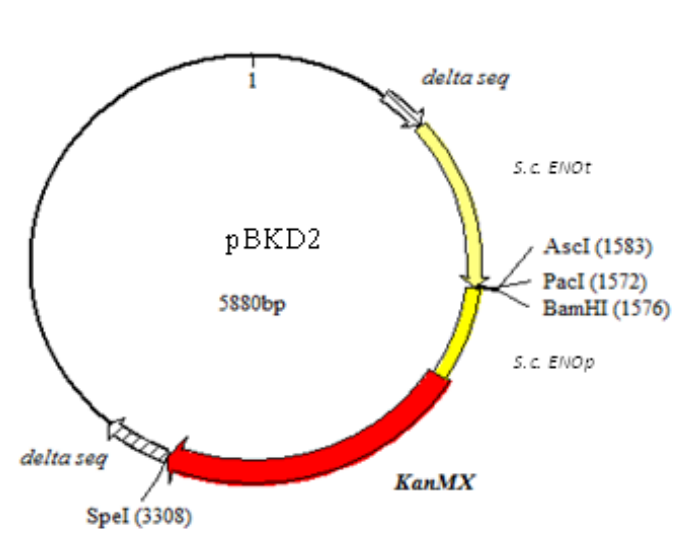

Figure 1A. Empty (a) episomal plasmid and (b) integration vectors expressing kanMX gene. 


\subsubsection{Primers for $q P C R$ copy number determination and Mat gene amplification}

Table 1A All plasmids and primers utilised in this study

\begin{tabular}{|c|c|c|}
\hline Name & Relevant genotype & Reference \\
\hline \multicolumn{3}{|l|}{ Plasmids } \\
\hline pMU1531 & bla ENO1p xyn2 S.f.cel3A ENO1 ${ }_{T}$ sh ble & This laboratory \\
\hline pBKD2 & bla $\delta$-site ENOIp-ENO1 ${ }_{T}$ kanMX $\delta$-site & This laboratory \\
\hline pRDH147 & Bla URA3 ENO1p T.r.cel5A ENO1 & This laboratory \\
\hline pRDH226 & bla $\delta$-site ENO1p T.e.cel7A ENO1 ${ }_{T}$ sh ble $\delta$-site & (8) \\
\hline pEMPTY & bla ENO1p-ENO1 ${ }_{T}$ kanMX & (2) \\
\hline pMUSD1 & bla ENO1p xyn2 S.f.cel3A ENO1 kanMX $^{2}$ & This work \\
\hline pMUSD2 & bla ENO1p T.r.cel5A ENO1 kanMX $^{2}$ & This work \\
\hline pMUSD3 & bla ENO1p T.e.cel7A ENO1 ${ }_{T}$ kanMX & This work \\
\hline pSDKD1 & 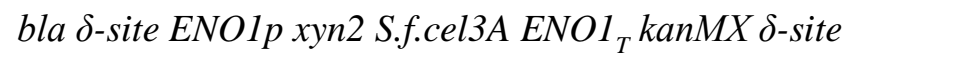 & This work \\
\hline pSDKD2 & bla $\delta$-site ENOIp T.r.cel5A ENO1 ${ }_{T} k a n M X \delta$-site & This work \\
\hline pSDKD3 & bla $\delta$-site ENO1p T.e.cel7A ENO1 ${ }_{T}$ kanMX $\delta$-site & This work \\
\hline \multicolumn{3}{|c|}{ 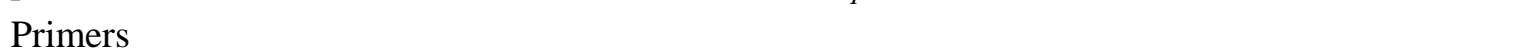 } \\
\hline S. fibuligera & L-GACTCGCGAGTCCCAATTCAAAACTATACC & This laboratory \\
\hline Cel3A & R-CCGCTCGAGCGGTCAAATAGTAAACAGGACAGATG & \\
\hline T. reesei & L- GTTAACAACAATTTGGGTGG & This laboratory \\
\hline Cel5A & $R-C A A T G G A G A A A A A G C A C C$ & \\
\hline T. emersonii & L-GACTTTAATTAAAATGCTAAGAAGAGCTTTACTATTG & (8) \\
\hline Cel7A & R-GACTGGCGCGCCTTACAAACATTGAGAGTAGTATGG & \\
\hline \multirow{3}{*}{$\begin{array}{l}\text { S. cerevisiae } \\
\text { MatA } \alpha\end{array}$} & L-ACTCCACTTCAAGTAAGAGTTTG & \multirow[t]{3}{*}{ (2) } \\
\hline & Mato-L-GCACGGAATATGGGACTACTTCG & \\
\hline & Mat locus-R GCA CGG AAT ATG GGA CTA CTT CG & \\
\hline \multirow{2}{*}{$\begin{array}{l}\text { S. cerevisiae } \\
A L G 9\end{array}$} & ALG9-L TGCATTTGCTGTGATTGTCA & \multirow[t]{2}{*}{ (1) } \\
\hline & ALG9-R GCCAGATTCCTCACTTGCAT & \\
\hline \multirow{2}{*}{ kanMX } & kanMX-L CCGCGATTAAATTCCAACAT & \multirow[t]{2}{*}{ This laboratory } \\
\hline & kanMX-R CGATAGATTGTCGCACCTGA & \\
\hline
\end{tabular}




\subsubsection{Scatter plots from flow cytometry}
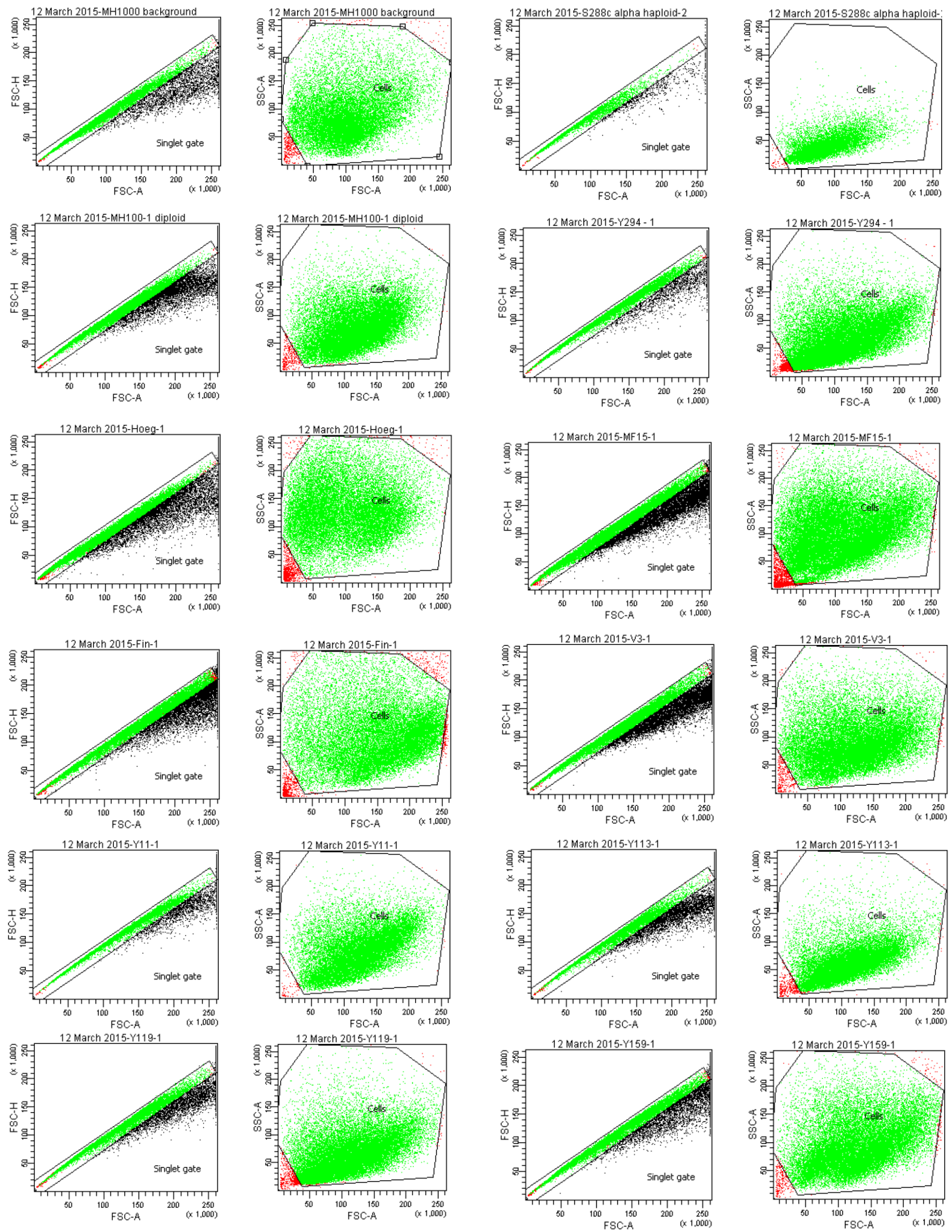

Figure 2A. Dot plots with a gate encompassing the yeast population. Correlated measurements of FSC and SSC allow for differentiation of cell types in a heterogeneous cell population. The cell sub-populations are based on forward scatter light (FSC) vs. side scatter light (SSC). The use of gating is to restrict analysis to one population and is denoted by the black line on the scatter plots. 


\subsubsection{Histograms statistics}
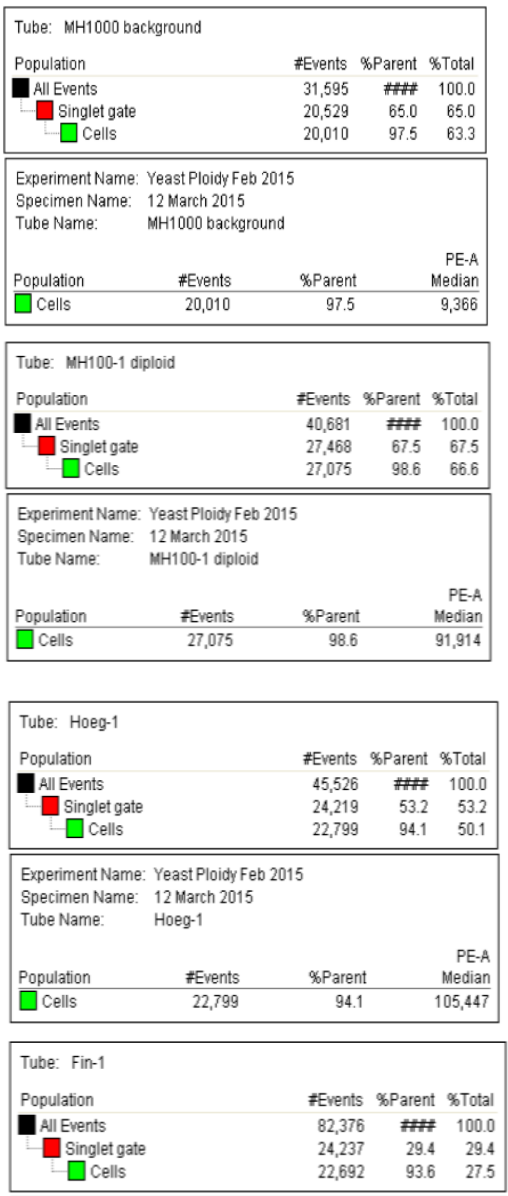

Experiment Name: Yeast Ploidy Feb 2015

Specimen Name: 12 March 2015

Tube Name: $\quad$ Fin-1

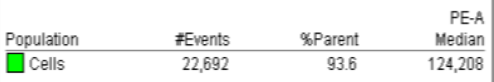

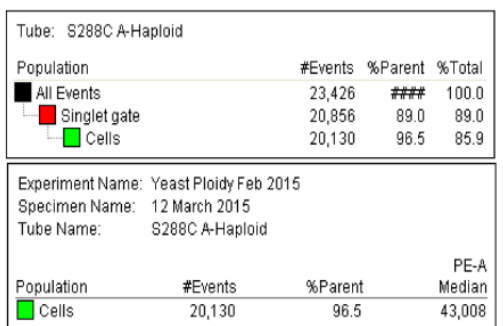
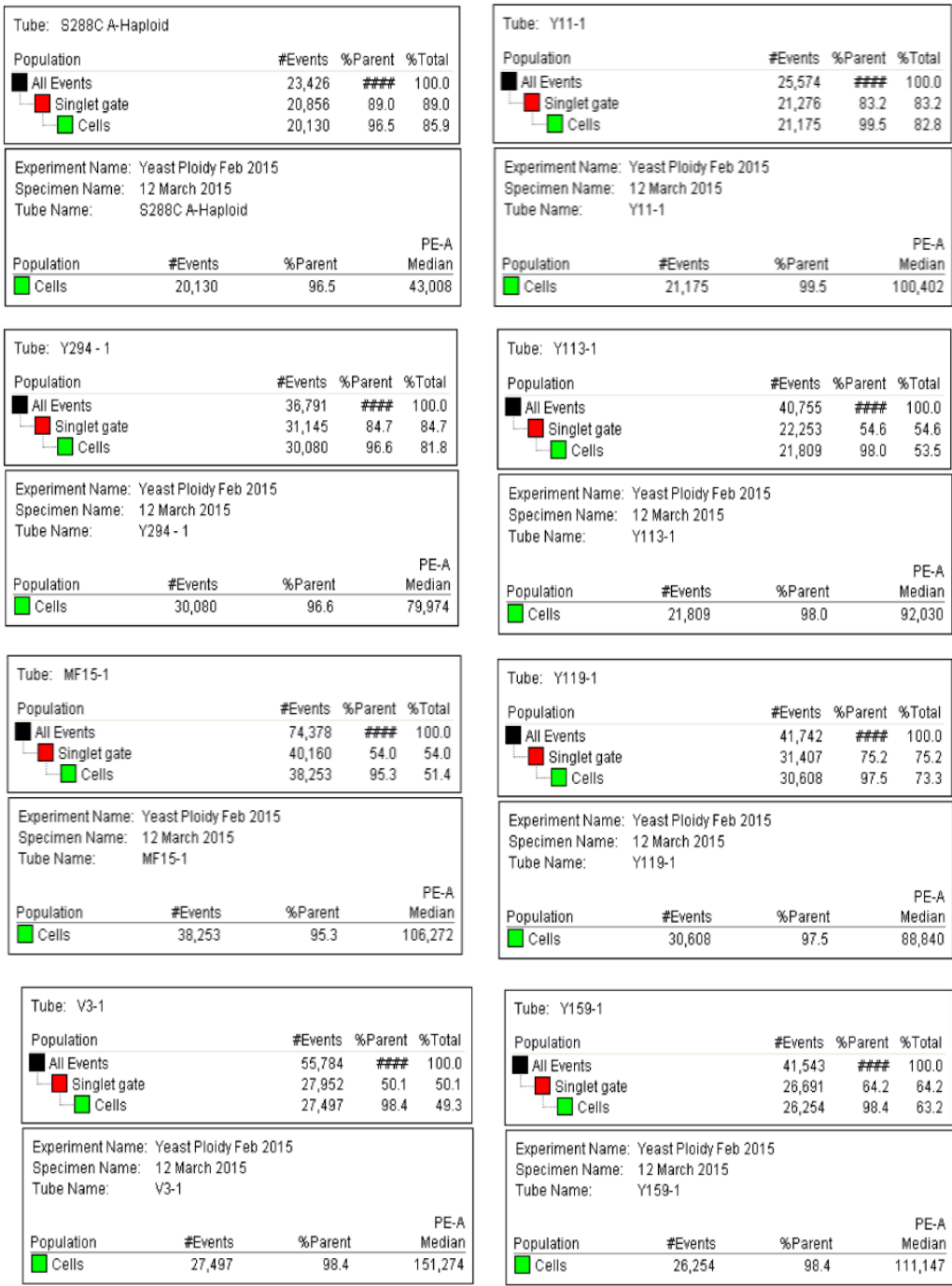

Figure 3A. Histogram statistics. Statistical percentages of the negatives and the positives are calculated by comparing the event count with the gated events. For example in data file labelled MH1000 background there are 31,595 events, but 20,010 events were found inside the gate. We want the percentage of cells that are positive, so we would look at the \%Parent for MH1000 background: $20010 / 31595=63.33 \%$. Because the populations that represent a DNA histogram $(\mathrm{G} 0 / \mathrm{G} 1, \mathrm{~S}$, and $\mathrm{G} 2+\mathrm{M})$ are not discrete, special algorithms are used. The area under the curve is integrated; then the percentages of each population present are calculated. 


\subsubsection{Ethanol tolerance assays}

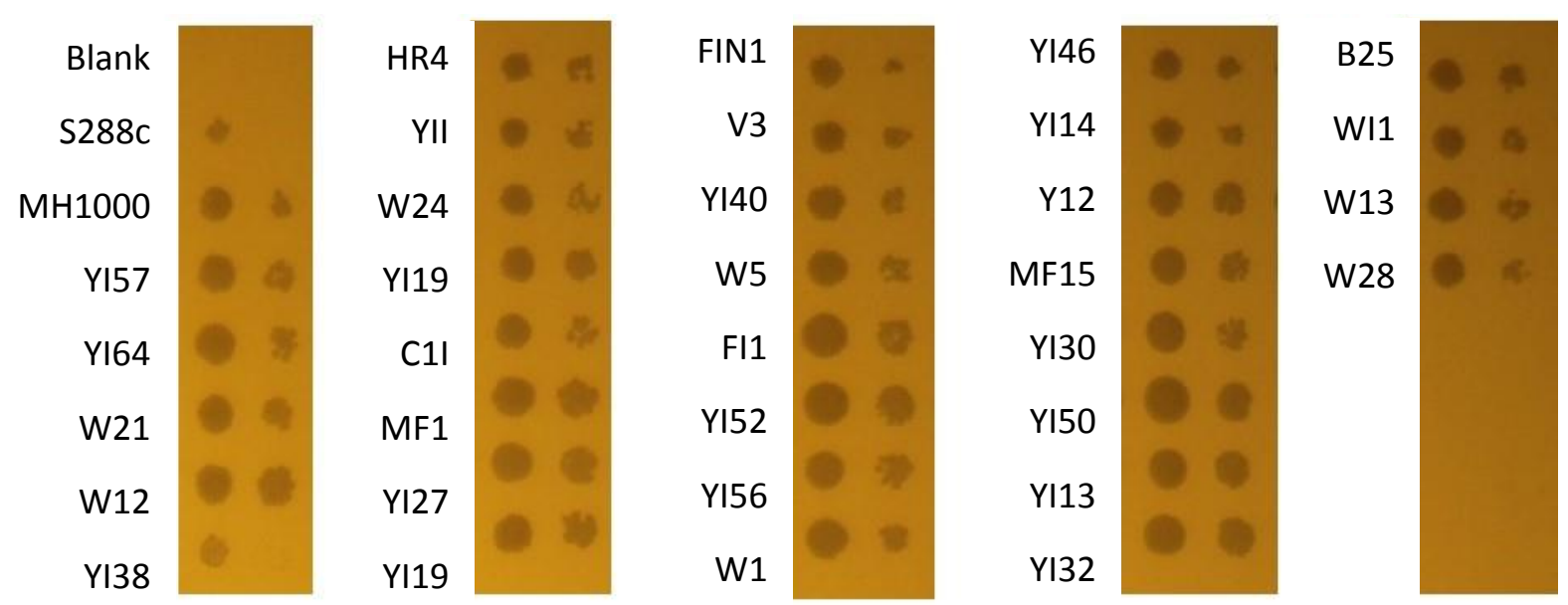

Figure 4A. Viability plate assay of natural strains compared to reference strains S288c and MH1000 cultivated for 7 days on YPD agar supplemented with $10 \% \mathrm{w} / \mathrm{v}$ ethanol.

\subsubsection{Composition of the inhibitory cocktail}

Table 2A. Inhibitory cocktail consisting of the major inhibitory compounds in lignocellulosic hydrolysate as described by Martin et al. (3).

\begin{tabular}{|c|c|c|}
\hline Components & Sub-components & Concentration $(\mathrm{g} / \mathrm{L})$ \\
\hline \multirow[t]{3}{*}{ Weak acids } & - Formic & 3.5 \\
\hline & - Acetic & 4.5 \\
\hline & - Levulinic & Not detected ${ }^{\mathrm{a}}$ \\
\hline \multirow[t]{2}{*}{ Furan aldehydes } & - $\quad$ Furfural & 2.9 \\
\hline & - 5-HMF & 3.8 \\
\hline \multirow[t]{2}{*}{ Phenolics } & - Cinnamic acid & 0.15 \\
\hline & - Coniferyl aldehyde & 0.18 \\
\hline
\end{tabular}

${ }^{a}$ Levulinic acid was not added to the cocktail mixture. 
Table 3A. Raw phenotypes scores, conditions, and stress doses used to make Figure 3.13.

\begin{tabular}{|c|c|c|c|c|c|c|c|c|c|c|c|c|c|c|c|c|c|c|c|c|c|c|c|c|c|c|c|c|}
\hline & \multicolumn{4}{|c|}{ Ethanol \% w/v } & \multicolumn{4}{|c|}{ Sodium Chloride } & \multicolumn{5}{|c|}{ Inhibitor cocktail } & \multicolumn{4}{|c|}{$37^{\circ} \mathrm{C}$ growth } & \multicolumn{4}{|c|}{$40^{\circ} \mathrm{C}$ growth } & \multicolumn{4}{|c|}{ Tunicamycin $(\mu \mathrm{g} / \mathrm{ml})$} & \multicolumn{3}{|c|}{$\begin{array}{l}\text { Sodium } \\
\text { Orthovanadate }\end{array}$} \\
\hline & $\underset{\infty}{\infty}$ & $\begin{array}{l}n \\
\infty \\
\infty\end{array}$ & $\stackrel{8}{\circ}$ & 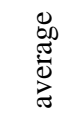 & \begin{tabular}{l}
$\sum_{\ddagger}$ \\
\multirow{0}{*}{}
\end{tabular} & $\begin{array}{l}\sum_{0} \\
0 \\
0\end{array}$ & 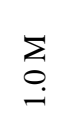 & 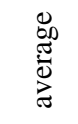 & हैं & $8^{\circ}$ & $\stackrel{\circ}{i}$ & $\Xi^{\circ}$ & 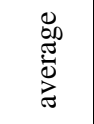 & - & $N$ & $m$ & 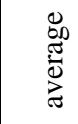 & - & $\mathrm{N}$ & $m$ & 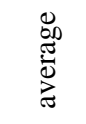 & $\tilde{0}$ & - & $m$ & 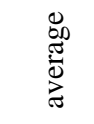 & $\underset{\Xi}{\sum}$ & $\underset{\Xi}{\sum_{n}}$ & 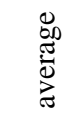 \\
\hline MH1000 & 2 & 2 & 1 & 1.7 & 3 & 3 & 3 & 3.0 & 3 & 2 & 2 & 2 & 2.5 & 3 & 3 & 3 & 3 & 3 & 2 & 2 & 2.33 & 1 & 2 & 2 & 1.67 & - & - & - \\
\hline S288c & 2 & 2 & 0 & 1.3 & 2 & 1 & 0 & 1.0 & 3 & 2 & 1 & 0 & 1.5 & 3 & 3 & 3 & 3 & 3 & 2 & 2 & 2.33 & 1 & 0 & 0 & 0.33 & - & - & - \\
\hline V3 & 3 & 3 & 2 & 2.7 & 2 & 2 & 2 & 2.0 & 3 & 3 & 1 & 0 & 1.75 & 3 & 3 & 3 & 3 & 3 & 2 & 2 & 2.33 & 1 & 0 & 3 & 1.33 & - & - & - \\
\hline YI19 & 2 & 3 & 2 & 2.3 & 3 & 3 & 2 & 2.7 & 3 & 3 & 1 & 1 & 2 & 3 & 3 & 3 & 3 & 3 & 2 & 2 & 2.33 & 1 & 0 & 1 & 0.67 & - & - & - \\
\hline YI59 & 0 & 0 & 0 & 0.0 & 3 & 3 & 3 & 3.0 & 3 & 1 & 2 & 0 & 1.5 & 3 & 3 & 0 & 2 & 0 & 0 & 0 & 0.00 & 3 & 3 & 3 & 3.00 & - & - & - \\
\hline YI11 & 2 & 3 & 2 & 2.3 & 0 & 0 & 0 & 0.0 & 3 & 3 & 2 & 0 & 2 & 3 & 3 & 3 & 3 & 3 & 2 & 2 & 2.33 & 3 & 3 & 3 & 3.00 & - & - & - \\
\hline YI13 & 3 & 3 & 2 & 2.7 & 3 & 2 & 2 & 2.3 & 3 & 3 & 2 & 2 & 2.67 & 3 & 3 & 3 & 3 & 3 & 2 & 2 & 2.33 & 3 & 3 & 3 & 3.00 & - & - & - \\
\hline MF15 & 1 & 1 & 0 & 0.7 & 1 & 2 & 2 & 2.3 & 3 & 3 & 2 & 2 & 2.67 & 3 & 3 & 0 & 2 & 0 & 0 & 0 & 0.00 & 1 & 1 & 0 & 0.67 & - & - & - \\
\hline S288c[empty] & 1 & 1 & 0 & 0.7 & 3 & 3 & 2 & 2.7 & 3 & 2 & 0 & 0 & 1.25 & 3 & 2 & 1 & 2 & 1 & 1 & 1 & 1.00 & 1 & 1 & 1 & 1.00 & 0 & 1 & 0.50 \\
\hline S288c_Cel7A & 2 & 0 & 0 & 0.7 & 3 & 3 & 2 & 2.7 & 3 & 2 & 1 & 0 & 1.5 & 3 & 3 & 3 & 3 & 0 & 0 & 0 & 0.00 & 2 & 2 & 1 & 1.67 & 3 & 1 & 2.00 \\
\hline S288c_Cel3A & 2 & 0 & 0 & 0.7 & 2 & 3 & 2 & 2.3 & 3 & 2 & 0 & 0 & 1.25 & 3 & 3 & 3 & 3 & 0 & 0 & 0 & 0.00 & 2 & 2 & 1 & 1.67 & 3 & 2 & 2.50 \\
\hline S288c_Cel5A & 3 & 2 & 1 & 2.0 & 2 & 3 & 2 & 2.3 & 3 & 2 & 1 & 0 & 1.5 & 3 & 2 & 2 & 2.3 & 0 & 0 & 0 & 0.00 & 2 & 2 & 1 & 1.67 & 3 & 1 & 2.00 \\
\hline FIN1 [empty] & 1 & 1 & 0 & 0.7 & 2 & 3 & 2 & 2.3 & 2 & 1 & 0 & 0 & 0.75 & 3 & 2 & 2 & 2.3 & 0 & 1 & 1 & 0.67 & 1 & 1 & 1 & 1.00 & 1 & 0 & 0.50 \\
\hline FIN1 [Cel7A] & 1 & 2 & 0 & 1.0 & 2 & 3 & 2 & 2.5 & 0 & 2 & 1 & 1 & 1 & 3 & 2 & 2 & 2.6 & 2 & 2 & 2 & 2.00 & 1 & 1 & 1 & 1.00 & 1 & 0 & 0.50 \\
\hline FIN1 [Cel3A] & 1 & 2 & 0 & 1.0 & 1 & 0 & 0 & 1.0 & 2 & 1 & 0 & 2 & 1.25 & 3 & 3 & 2 & 2.0 & 2 & 2 & 2 & 2.00 & 2 & 1 & 0 & 1.00 & 1 & 0 & 0.50 \\
\hline FIN1 [Cel5A] & 3 & 2 & 0 & 1.7 & 1 & 1 & 0 & 1.0 & 0 & 1 & 0 & 2 & 0.75 & 3 & 2 & 2 & 2.3 & 2 & 2 & 2 & 2.00 & 1 & 0 & 1 & 0.67 & 1 & 0 & 0.50 \\
\hline
\end{tabular}




\begin{tabular}{|c|c|c|c|c|c|c|c|c|c|c|c|c|c|c|c|c|c|c|c|c|c|c|c|c|c|c|c|c|}
\hline & \multicolumn{4}{|c|}{ Ethanol \% w/v } & \multicolumn{4}{|c|}{ Sodium Chloride } & \multicolumn{5}{|c|}{ Inhibitor cocktail } & \multicolumn{4}{|c|}{$37^{\circ} \mathrm{C}$ growth } & \multicolumn{4}{|c|}{$40^{\circ} \mathrm{C}$ growth } & \multicolumn{4}{|c|}{ Tunicamycin $(\mu \mathrm{g} / \mathrm{ml})$} & \multicolumn{3}{|c|}{$\begin{array}{c}\text { Sodium } \\
\text { Orthovanadate }\end{array}$} \\
\hline & $\begin{array}{l}8 \\
\infty\end{array}$ & 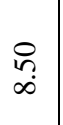 & $\stackrel{8}{\circ}$ & 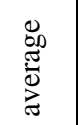 & $\begin{array}{l}\sum_{1} \\
0 \\
0\end{array}$ & $\begin{array}{l}\sum_{0} \\
b \\
0 \\
0\end{array}$ & $\begin{array}{l}\Sigma \\
0 \\
\end{array}$ & 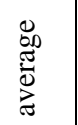 & ڤึ & $\stackrel{8}{8}$ & $\stackrel{\circ}{i n}$ & $\stackrel{\circ}{0}$ & 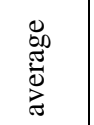 & - & $\sim$ & $m$ & 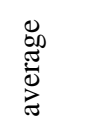 & - & r & $m$ & 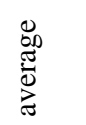 & ฮี & - & m & 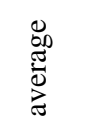 & $\underset{g}{\grave{g}}$ & $\underset{\Xi}{n}$ & 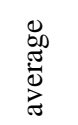 \\
\hline FIN1_Cel7A & 2 & 1 & 0 & 1.0 & 2 & 1 & 2 & 1.7 & 3 & 2 & 2 & 0 & 1.75 & 3 & 2 & 2 & 2.33 & & 1 & 1 & 1.00 & 2 & 2 & 0 & 1.33 & 3 & 0 & 1.50 \\
\hline FIN1_Cel3A & 2 & 1 & 0 & 1.0 & 2 & 1 & 0 & 1.0 & 2 & 2 & 1 & 0 & 1.25 & 3 & 3 & 2 & 2.67 & 1 & 0 & 0 & 0.33 & 2 & 2 & 0 & 1.33 & 3 & 0 & 1.50 \\
\hline FIN1_Cel3A & 2 & 1 & 0 & 1.0 & 2 & 1 & 0 & 1.0 & 3 & 2 & 2 & 0 & 1.75 & 2 & 2 & 2 & 2.00 & 0 & 0 & 1 & 0.3 & 2 & 2 & 0 & 1.33 & & 0 & 1.50 \\
\hline YI13 [empty] & 3 & 3 & 3 & 3.0 & 2 & 0 & 2 & 1.3 & 2 & 3 & 2 & 3 & 2.5 & 3 & 3 & 3 & 3.00 & 3 & 3 & 3 & 3.00 & 3 & 3 & 3 & 3.00 & 3 & 1 & 2.00 \\
\hline YI13 [Cel7A] & 2 & 2 & 1 & 1.7 & 2 & 2 & 2 & 2.0 & 3 & 3 & 2 & 3 & 2.75 & 3 & 3 & 3 & 3.00 & 3 & 3 & 3 & 3.00 & 3 & 3 & 3 & 3.00 & 1 & 1 & 1.00 \\
\hline YI13 [Cel3A] & 3 & 3 & 0 & 2.0 & 2 & 2 & 2 & 2.0 & 3 & 3 & 2 & 3 & 2.75 & 3 & 3 & 3 & 3.00 & 3 & 3 & 3 & 3.00 & 3 & 3 & 3 & 3.00 & 1 & 2 & 2.00 \\
\hline YI13 [Cel5A] & 3 & 3 & 3 & 3.0 & 2 & 2 & 2 & 2.0 & 3 & 3 & 2 & 3 & 2.75 & 3 & 3 & 3 & 3.00 & 3 & 3 & 3 & 3.00 & 2 & 1 & 1 & 1.33 & 1 & 0 & 0.50 \\
\hline YI13_CC & 3 & 3 & 2 & 2.7 & 2 & 2 & 2 & 2.0 & 3 & 2 & 2 & 0 & 1.75 & 3 & 3 & 3 & 3.00 & 2 & 3 & 2 & 2.33 & 3 & 2 & 1 & 2.00 & 1 & 1 & 1.50 \\
\hline YI13_Cel3A & 3 & 3 & 2 & 2.7 & 1 & 3 & 2 & 2.0 & 3 & 3 & 2 & 3 & 2.75 & 3 & 3 & 3 & 3.00 & 2 & 2 & 2 & 2.00 & 3 & 3 & 1 & 2.33 & 3 & 1 & 1.50 \\
\hline YI13_Cel5A & 3 & 3 & 1 & 2.3 & 2 & 3 & 2 & 2.3 & 3 & 3 & 2 & 3 & 2.75 & 3 & 3 & 3 & 3.00 & 2 & 2 & 2 & 2.00 & 3 & 2 & 1 & 2.00 & 1 & 0 & 1.50 \\
\hline MF15 [empty] & 2 & 1 & 1 & 1.3 & 3 & 3 & 2 & 2.7 & 2 & 1 & 0 & 0 & 0.75 & 3 & 2 & 2 & 2.33 & 2 & 2 & 2 & 2.00 & 1 & 0 & 0 & 0.33 & 3 & 0 & 1.50 \\
\hline MF15 [Cel7A] & 2 & 1 & 0 & 1.0 & 2 & 2 & 2 & 2.0 & 0 & 2 & 1 & 1 & 1.00 & 3 & 2 & 2 & 2.33 & 2 & 2 & 2 & 2.00 & 0 & 0 & 0 & 0.00 & 3 & 0 & 1.50 \\
\hline MF15 [Cel3A] & 0 & 0 & 0 & 0.0 & 2 & 2 & 2 & 2.0 & 2 & 1 & 0 & 2 & 1.25 & 3 & 3 & 3 & 3.00 & 2 & 2 & 2 & 2.00 & 0 & 0 & 0 & 0.00 & 3 & 0 & 1.50 \\
\hline MF15 [Cel5A] & 1 & 0 & 0 & 0.3 & 2 & 2 & 2 & 2.0 & 0 & 1 & 0 & 2 & 0.75 & 3 & 3 & 3 & 3.00 & 2 & 2 & 2 & 2.00 & 0 & 0 & 0 & 0.00 & 3 & 0 & 1.50 \\
\hline MF15_Cel7A & 2 & 1 & 1 & 1.3 & 3 & 3 & 2 & 2.7 & 3 & 2 & 2 & 0 & 1.75 & 3 & 3 & 3 & 3.00 & 2 & 2 & 2 & 2.00 & 1 & 1 & 0 & 0.67 & 3 & 0 & 1.50 \\
\hline MF15_Cel3A & 2 & 1 & 0 & 1.0 & 2 & 3 & 2 & 2.3 & 2 & 2 & 1 & 0 & 1.25 & 3 & 3 & 3 & 3.00 & 2 & 2 & 2 & 2.00 & 1 & 3 & 0 & 1.33 & 3 & 0 & 1.50 \\
\hline MF15_Cel5A & 2 & 1 & 0 & 1.0 & 2 & 2 & 2 & 2.0 & 3 & 2 & 2 & 0 & 1.75 & 3 & 3 & 3 & 3.00 & 2 & 2 & 2 & 2.00 & 2 & 1 & 1 & 1.33 & 3 & 0 & 1.50 \\
\hline
\end{tabular}




\subsubsection{Cell viability assays}

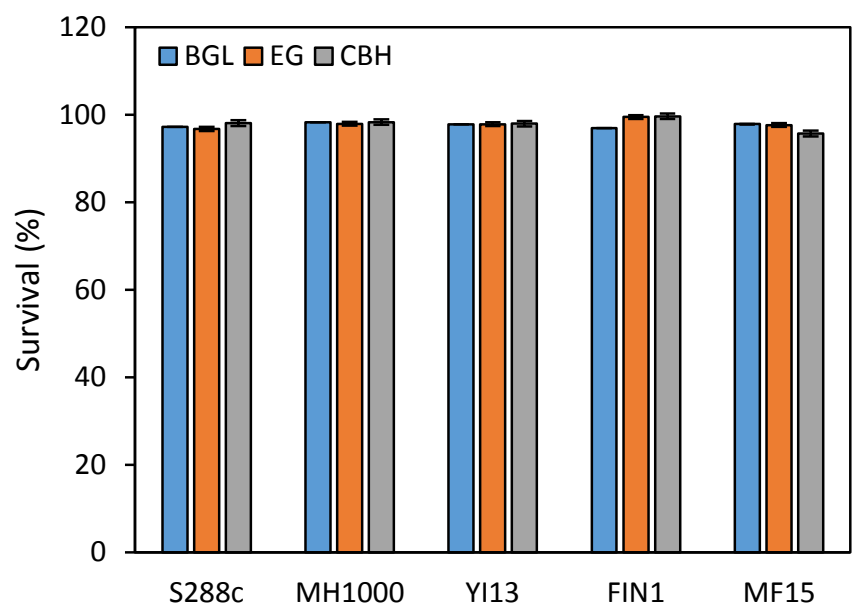

Figure 5A. Cell viability of $S$. cerevisiae transformants after $72 \mathrm{~h}$ cultivation under G418 selective pressure was measured using methylene blue straining technique (4). Measurements were simultaneously taken with the activity assays.

\subsubsection{Protein determination}

The differences in cellulase enzyme production and secretion may arise from divergences in other endogenous factors involved in any step between transcription and translation, including post-translational events such as protein glycosylation and stability (5). Since secretion of glycosylated proteins in $S$. cerevisiae is often reduced due to incorrect glycosylation and misfolding inside the cell (5), the degree of glycosylation performed by each strain was an important factor to evaluate in this study. Expression of cellulase genes in diverse genetic backgrounds can yield different forms of proteins some of which are known to affect enzyme function (6). These differences might arise from changes in the glycosylation properties of the heterologous proteins that, in turn, change the characteristics of the enzyme (7). In order to investigate this possibility, the superior episomal transformants were selected to study the glycosylation of the proteins secreted into the media. Since secretion of glycosylated proteins in S. cerevisiae is often reduced due to incorrect glycosylation and misfolding inside the cell (6), the degree of glycosylation performed by each strain was an important factor to evaluate.

The production level of the secreted cellulase activities were too low to detect by SDS-PAGE and silver staining (Figure 6A). Previous work suggested that the expected sizes of S.f.Cel3A, T.r.Cel5A and T.e.Cel7A proteins was $120 \mathrm{kDa}, 48 \mathrm{kDa}$ and $62 \mathrm{kDa}$ (after the removal of $N$-glycans with Endo $\mathrm{H}$ treatment) $(6,8)$. To identify differential bands, zymogram analysis were performed (Figure 6Ac \& d). No difference in band size of glycosylated proteins between 
the natural and reference strains was observed, suggesting that the differences in secretion levels of cellulolytic enzymes synthesised in natural strains have another cause.

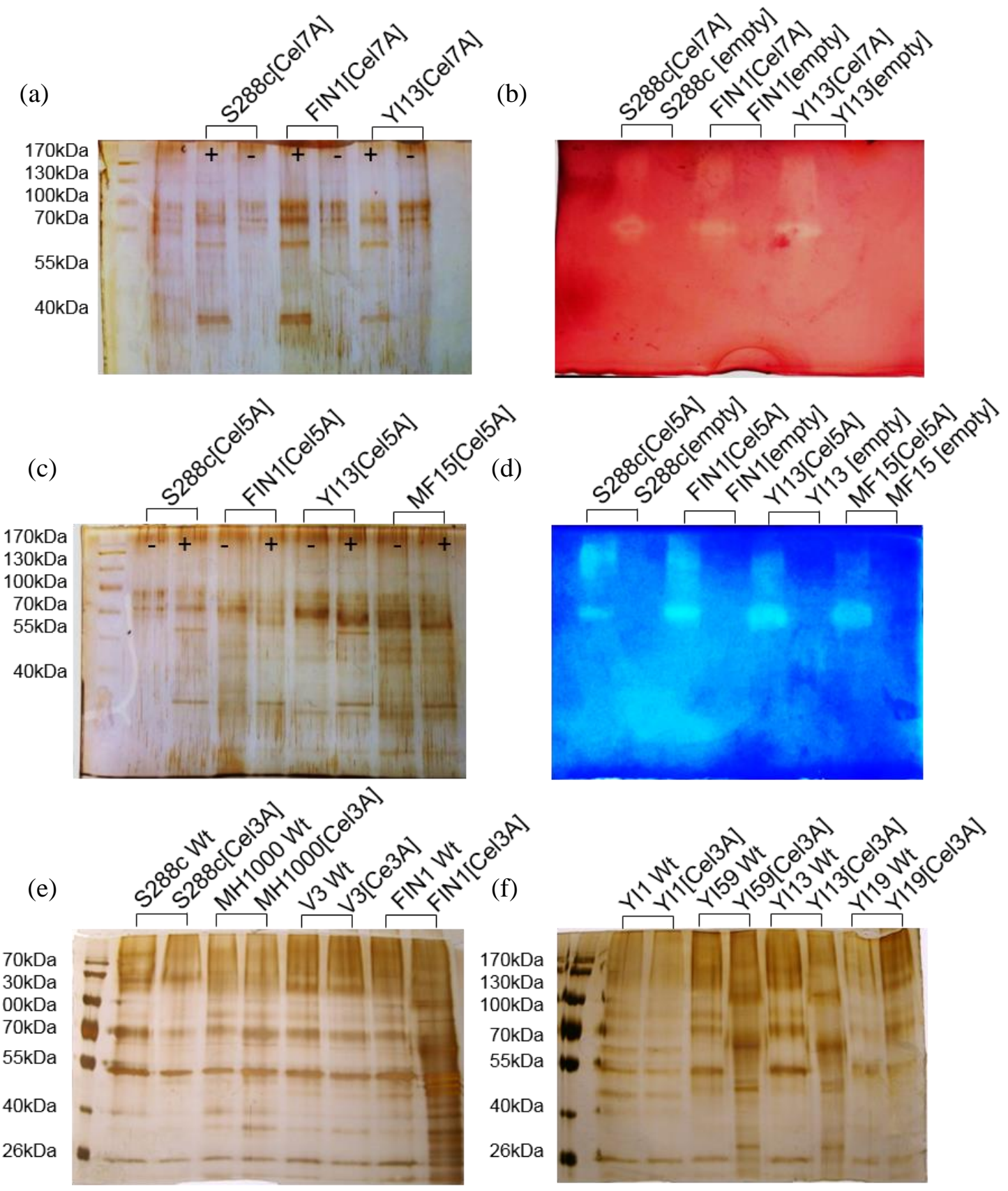

Figure 6A. Silver stained 10\% SDS-PAGE gels (a-c, f) and zymogram analysis (d \& e) of the secreted proteins from transformants expressing T.e.cel7A, T.r.cel5A and S.f.cel3A. (+) Denotes deglycosylated samples, (-) denotes untreated samples, (Wt) denotes wild-type strains and the [ ] denotes episomal transformants.

After performing various protein concentrating and purifying techniques, the SDS-PAGE analyses were inconclusive, as the $S$. cerevisiae strains secreted relatively large amounts of 
native proteins which interfered with visualisation of protein bands. The natural S. cerevisiae strains secreted relatively large amounts of native proteins compared to reference strain S288c, as seen in the SDS-PAGE results (Figure 6Aa $\boldsymbol{\&} \mathbf{b}$ ), which may set special demands for the capacity of its cells to fold and transport proteins. Another reason for low expression levels of the S.f.Cel3A in the supernatant is that a majority of the S.f.Cel3A activity was remained within the periplasmic space or associated with the cell wall, as suggested by Gurgu et al. (9).

\subsubsection{Growth assays of transformants in aerobic conditions}

(a) S.f.cel3A episomal expression (b) T.r.cel5A episomal expression (c) T.e.cel7A episomal expression
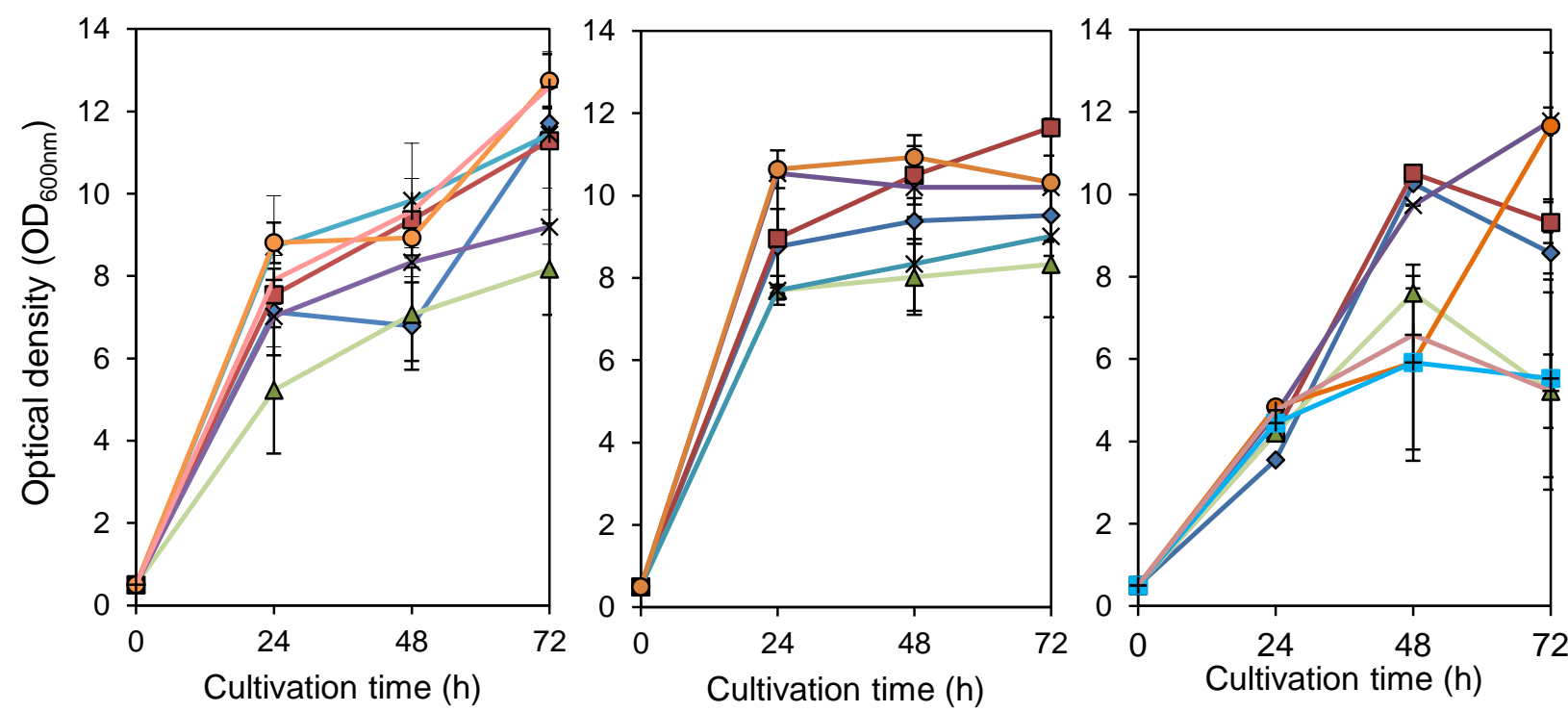

$\diamond \mathrm{MH} 1000-\square-\mathrm{S} 288 \mathrm{c} \Delta \mathrm{FIN1} \times \mathrm{YI13} * \mathrm{MF} 15-\mathrm{O}$ Hoeg $+\mathrm{Y} 294$

Figure 7A. Cell biomass ( $\left.\mathrm{OD}_{600 \mathrm{~nm}}\right)$ of transformants grown in $\mathrm{YP}$ with $2 \%$ glucose over $72 \mathrm{~h}$ period. 


\subsubsection{Raw data of co-culture fermentations with Avicel cellulose}

(a) No added BGL
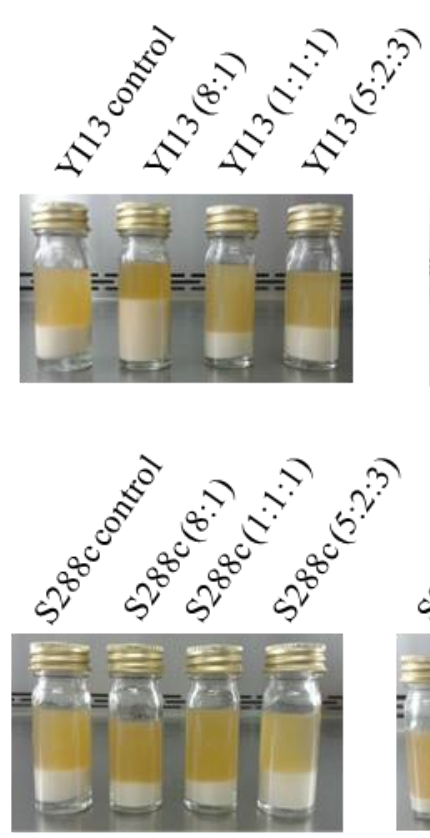

(b) Externally added BGL
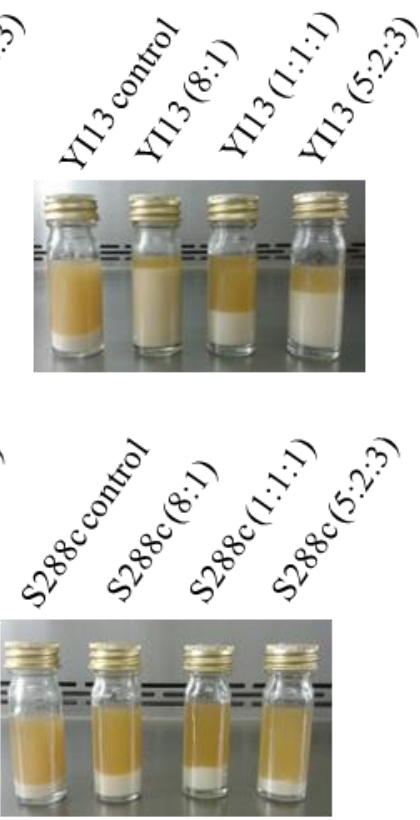

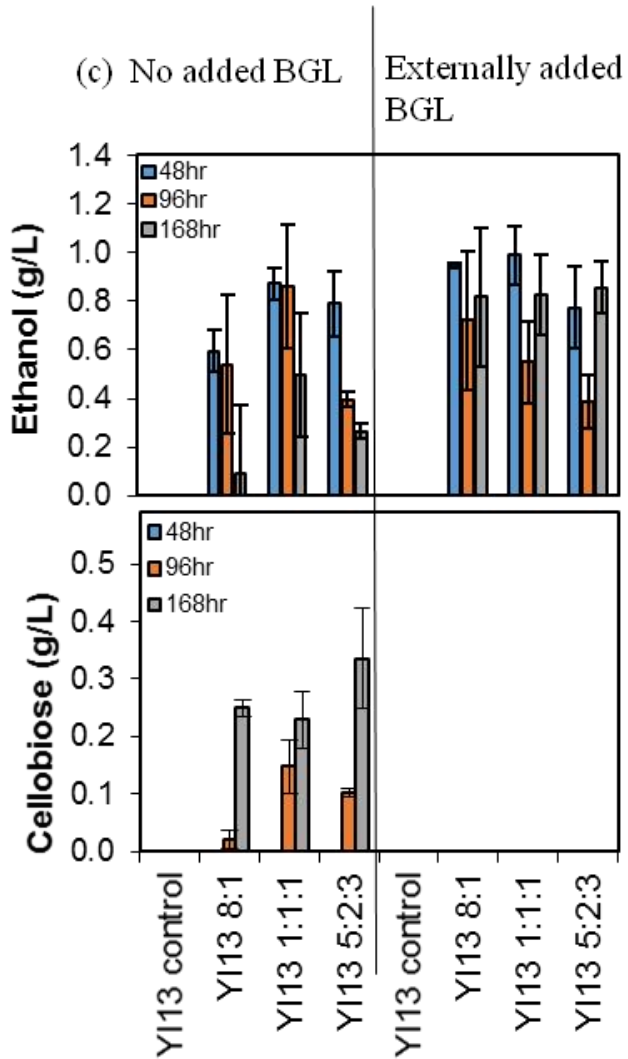

Figure 8A. (a-b) Visual representation of Avicel precipitate (after $168 \mathrm{~h}$ ) and (c) chemical analysis of the supernatant of co-culture fermentations with and without externally added Novozyme 188 (BGL).

\subsubsection{Raw data of stress tolerance assays}

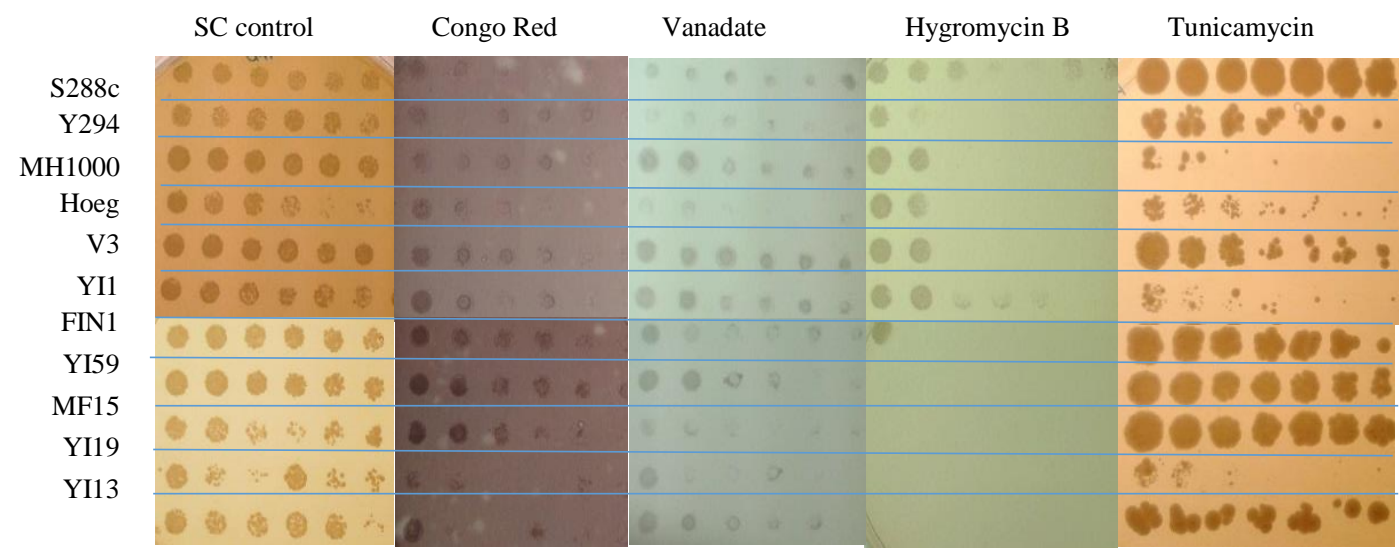

Figure 9A. Analysis of 2-fold serial dilutions of natural strains with reference strains S288c, Y294, MH1000 and Hoeg in a plate viability assay after $24 \mathrm{~h}$. Resistance to $50 \mu \mathrm{g} / \mathrm{mL}$ Congo Red, $50 \mu \mathrm{g} / \mathrm{mL}$ sodium orthovanadate, $150 \mu \mathrm{g} / \mathrm{mL}$ hygromycin $\mathrm{B}$ and $0.3 \mu \mathrm{g} / \mathrm{mL}$ tunicamycin (after $48 \mathrm{~h}$ ) were evaluated using SC agar supplemented with various inhibitors. 


\subsubsection{Stress tolerance compounds and mode of action}

Table 4A. Mode of action of secretion, endoplasmic reticulum and cell wall stresses used in this study.

\begin{tabular}{|c|c|c|c|}
\hline Component & Mechanism & Indication & Ref. \\
\hline Tunicamycin & $\begin{array}{l}\text { An antibiotic that prevents glycosylation of glycoproteins by blocking the } \\
\text { formation of } \mathrm{N} \text {-acetylglucosamine-lipid intermediates, resulting in } \\
\text { endoplasmic reticulum stress. }\end{array}$ & $\begin{array}{l}\text { Indicative of tolerance } \\
\text { to secretion stress. }\end{array}$ & (10) \\
\hline Sodium orthovanadate & $\begin{array}{l}\text { The mechanism of vanadate toxic effect is connected with its structural } \\
\text { similarity to phosphate. As a phosphate analogue it inhibits activity of } \\
\text { phosphate metabolism i.e. ATPases, RNAses, kinases and phosphoprotein } \\
\text { phosphatates. Bisconti et al. (102) suggest the reaction occurs on the cell } \\
\text { envelope rather than intracellularly. Shown in S. cerevisiae, vanadate } \\
\text { inhibits the release of secretion vesicle (106). }\end{array}$ & $\begin{array}{l}\text { Indicative of defects in } \\
\text { glycosylation and } \\
\text { general secretion } \\
\text { pathway. }\end{array}$ & $(11,12)$ \\
\hline Congo Red & $\begin{array}{l}\text { A dye that interferes with proper cell wall assembly. The primary target of } \\
\text { Congo red is chitin in S. cerevisiae. It interferes with the construction and } \\
\text { stress response of the cell wall. }\end{array}$ & $\begin{array}{l}\text { Indicative of cell wall } \\
\text { integrity. }\end{array}$ & $(13,14)$ \\
\hline Hygromycin B & $\begin{array}{l}\text { An aminoglycoside antibiotic in that it has dual inhibitory effects on } \\
\text { translation; it interferes with both ribosomal translocation and with } \\
\text { aminoacyl-t-RNA recognition. }\end{array}$ & $\begin{array}{l}\text { Indicative of defects in } \\
\text { vacuolar trafficking } \\
\text { and/or function. }\end{array}$ & $(15-17)$ \\
\hline
\end{tabular}




\subsection{References}

1. Van Zyl JHD, Den Haan R, Van Zyl WH. 2014. Over-expression of native Saccharomyces cerevisiae exocytic SNARE genes increased heterologous cellulase secretion. Appl Microbiol Biotechnol.

2. Kroukamp H. 2015. Improving the protein secretion capacity of Saccharomyces cerevisiae with strain engineering. PhD Dissertation. Stellenbosch Univeristy, South Africa.

3. Martin C, Jönsson LJ. 2003. Comparison of the resistance of industrial and laboratory strains of Saccharomyces and Zygosaccharomyces to lignocellulose-derived fermentation inhibitors 32:386-395.

4. Smart KA, Chambers KM, Lambert I, Jenkins C, Smart CA. 1999. Use of methylene violet staining procedures to determine yeast viability and vitality. J Am Soc Brew Chem 57:18-23.

5. Jeoh T, Michener W, Himmel ME, Decker SR, Adney WS. 2008. Implications of cellobiohydrolase glycosylation for use in biomass conversion Biotechnology for Biofuels conversion.

6. Idiris A, Tohda H, Kumagai H, Takegawa K. 2010. Engineering of protein secretion in yeast: strategies and impact on protein production. Appl Microbiol Biotechnol 86:403-17.

7. Kruszewska JS, Perlińska-lenart U, Górka-nieć W, Orlowski J, Zembek P, Palamarczyk G. 2008. Alterations in protein secretion caused by metabolic engineering of glycosylation pathways in fungi 55:447-456.

8. Ilmén M, den Haan R, Brevnova E, McBride J, Wiswall E, Froehlich A, Koivula A, Voutilainen SP, Siika-Aho M, la Grange DC, Thorngren N, Ahlgren S, Mellon M, Deleault K, Rajgarhia V, van Zyl WH, Penttilä M. 2011. High level secretion of cellobiohydrolases by Saccharomyces cerevisiae. Biotechnol Biofuels 4:30.

9. Gurgu L, Lafraya Á, Polaina J, Marín-Navarro J. 2011. Fermentation of cellobiose to ethanol by industrial Saccharomyces strains carrying the $\beta$-glucosidase gene (BGL1) from Saccharomycopsis fibuligera. Bioresour Technol 102:5229-36.

10. Bull VH, Thiede B. 2012. Proteome analysis of tunicamycin-induced ER stress. Electrophoresis 33:1814-23.

11. Kanik-ennulat C, Montalvo E, Neff N. 1995. Sodium Orthovanadate-Resistant Mutants of. In Vivo. PhD Dissertation. (Brooklyn).

12. Schägger H, von Jagow G. 1987. Tricine-sodium dodecyl sulfate-polyacrylamide gel electrophoresis for the separation of proteins in the range from 1 to $100 \mathrm{kDa}$. Anal Biochem 166:368-79.

13. Ram AFJ, Klis FM. 2006. Identification of fungal cell wall mutants using susceptibility assays based on Calcofluor white and Congo red. Nat Protoc 1:2253-2256.

14. Krysan DJ. 2009. The cell wall and endoplasmic reticulum stress responses are coordinately regulated in Saccharomyces cerevisiae. Commun Integr Biol 2:233-5. 
15. Banuelos MG, Moreno DE, Olson DK, Nguyen Q, Ricarte F, Aguilera-Sandoval CR, Gharakhanian E. 2010. Genomic analysis of severe hypersensitivity to hygromycin B reveals linkage to vacuolar defects and new vacuolar gene functions in Saccharomyces cerevisiae. Curr Genet 56:121-137.

16. Machi K, Azuma M, Igarashi K, Matsumoto T, Fukuda H, Kondo A, Ooshima H. 2004. Rot1p of Saccharomyces cerevisiae is a putative membrane protein required for normal levels of the cell wall 1,6-beta-glucan. Microbiology 150:3163-73.

17. Ballou L, Hitzeman R A, Lewis MS, Ballou CE. 1991. Vanadate-resistant yeast mutants are defective in protein glycosylation. Proc Natl Acad Sci U S A 88:3209-12. 